\title{
FORMAÇÃO E INSERÇÃO INSTITUCIONAL DE AGENTES INDÍGENAS DE SAÚDE NO SISTEMA ÚNICO DE SAÚDE: UM ESTUDO DE POSSIBILIDADES
}

\section{LAVÍNIA SANTOS DE SOUZA OLIVEIRA}

Tese de Doutorado apresentada à Faculdade de Saúde Pública da Universidade de São Paulo, para obtenção do Grau de Doutor.

Área de concentração: Serviços de Saúde Pública

ORIENTADORA:

Profa. Titular Evelin Naked de Castro Sá

São Paulo

2002

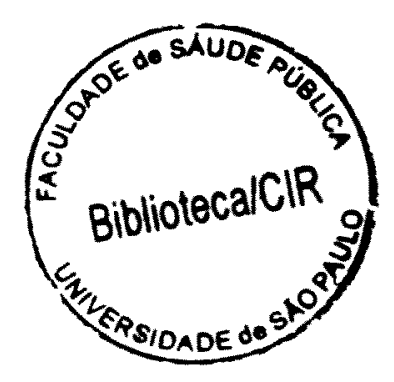




$$
47781 / 2006 \mathrm{cg}
$$

Autorizo, exclusivamente para fins acadêmicos e científicos, a reprodução total ou parcial desta tese por processos fotocopiadores.

Assinatura:

Data: $31 / 5 / 02$ 


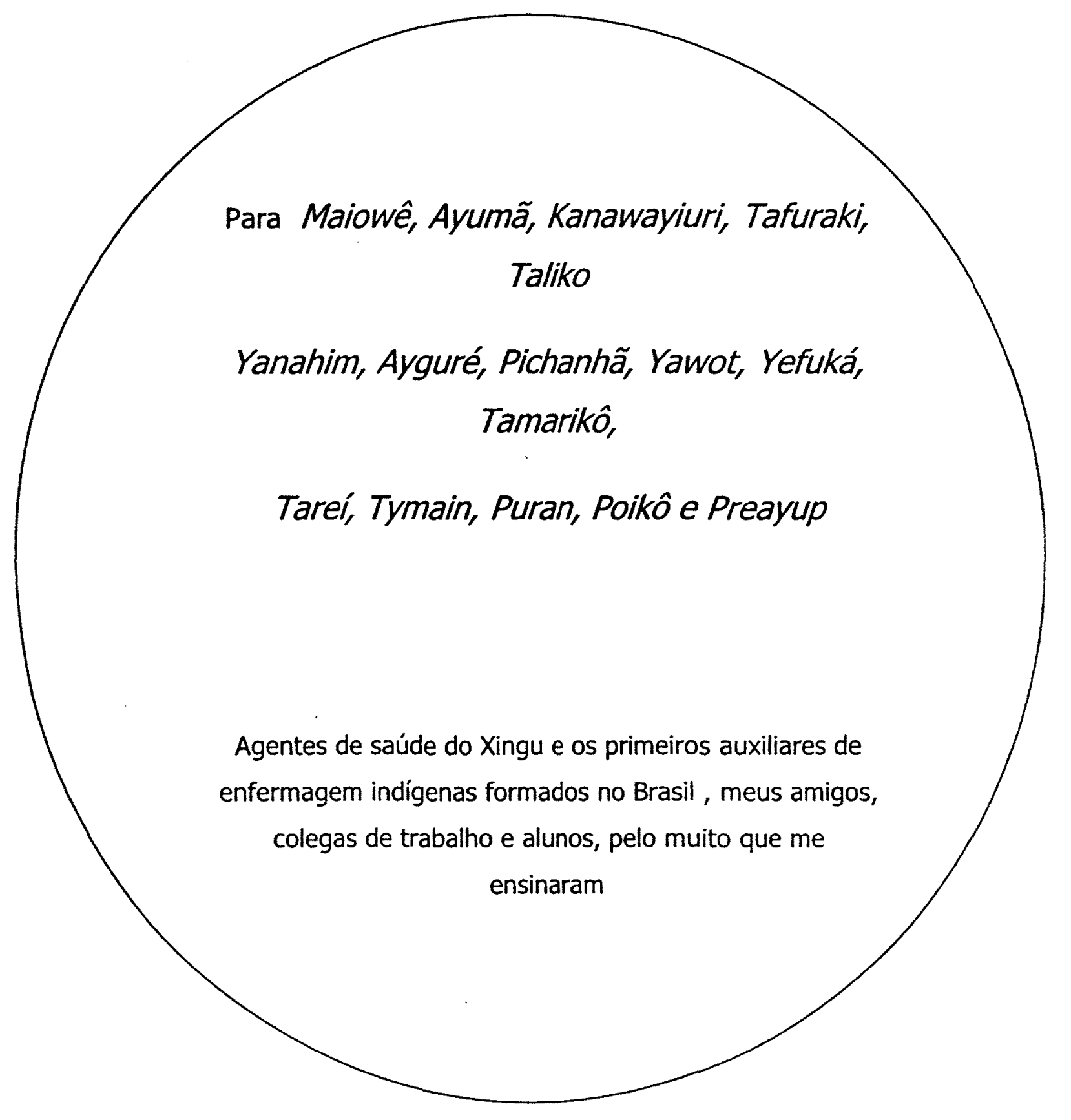




\section{Agradecimentos}

Este trabalho é quase uma obra coletiva, tantos foram os que dele participaram com incentivo, apoio, discussões, levantamento de material, leituras, digitação, e revisões. Sou grata a todos que se deixaram despertar e envolver pelo tema, especialmente as seguintes instituições e pessoas:

Faculdade de Saúde Pública da USP;

Departamento de Medicina Preventiva da UNIFESP;

Prefeitura do Município de São Paulo;

Fundação Nacional de Saúde;

Instituto Sócio Ambiental;

Associação Terra Indígena do Xingu;

Douglas Rodrigues e Sofia Mendonça, pela amizade que fez a oportunidade de trabalhar no Xingu e concretizarmos juntos tantos sonhos, ousadias e lutas;

Profa. Evelin, mais que orientadora, pela paciência com minhas indisciplinas, sensibilidade política e o modo de fazer ciência com afeto;

Prof. Roberto Baruzzi, co-orientador informal, pelo incentivo, exemplo de vida e trabalho que fazem dele um grande mestre;

Aos membros da banca, profa. Carmem Junqueira, profa. Roseli Fishmann, profa. Márcia Wetphal e profa. Cleide Lavieri, pela colaboração e sugestões enriquecedoras;

Aos amigos e companheiros do DISEI Xingu, que compartilham da prática de trabalhar, ensinar e aprender ao mesmo tempo. Um grupo grande e especial, de profissionais indígenas e não indígenas, representado aqui por 
Marina Machado, Castorina Santos, Estela Wurker, Eduardo Biral, Selma Carneiro e Gisela Serejo;

As lideranças do Xingu, Mairawê Kaiabi, Macupá Kaiabi, Kokoti Aweti, Aritana Yawalapiti, Takumã Kamaiurá, Melobô Ikpeng, Sucuri Kamaiurá, (in memorian) e Miguel Waurá, pelos ensinamentos que nasceram de conversas informais, desvelando sabedoria e ciência nova para mim;

Aos amigos e colegas do Departamento de Prática de Saúde Pública da FSP/USP, Cleide, Helena, Alice, Pedro Germano, Sueli Dallari, Cidinha, Regina, Marinei, Sônia e Mila pelo apoio constante que viabilizou e concretizou este estudo;

Ao grupo de etnia e saúde da FSP/USP que está nascendo em tempo tão oportuno: João Yunes, seu idealizador e Sônia Phillipi, Rubens Adorno e Ana Caricari.

Aos companheiros do CEPEDOC/Projeto Bertioga Município Saudável, os queridos Ana Maria Caricari, Paulo Capucci, Francisco, Rosilda, Letícia, Adolfo Wera Mirim e Marina, pela oportunidade de vivenciar novas realidades indígenas;

Aos amigos do grupo de trabalho sobre formação de agentes de saúde da FUNASA, Ena Galvão, Marina, Maria, Ademir, Eugênia, Cida, Wellington e Ubiratan Pedrosa, pela ampliação de horizontes e discussões tão apaixonantes quanto o trabalho que fizemos juntos.

A Carla Stephens ( in memorian) e familia, que me acolheram no Canadá, propiciando a experiência de conhecer e aprender possibilidades sobre inserção universitária e institucional com os povos indígenas do Norte.

Aos amigos do Hospital São Luiz, Rui Marco Antônio, Maria Lúcia Forte, Maria Alice, Vera, Adriana, Samara e Rita, que apoiaram uma mudança de vida que gerou essa tese e pelo modo tão humano de fazer $\mathrm{RH}$. 
A minha família, pelos valores de vida, formação intelectual, incentivo e tolerância com tantas viagens e ausências. Especialmente agradeço a Dea, Paulo, Debinha, Edman, Eufe, Bibi, Malú, Joana, Gabriel, Mathias, Paulinho, Leni, Paulo André, Betão e Heloísa e os quase-família Ester, Eli, Nilza, Anderson e Inês.

A Deus ou Mavutsin, Nhanderu, Aimerê, Tuiararé, Senhor de todas as coisas e da diversidade entre os povos. 


\section{RESUMO}

Oliveira LSS Formação e Inserção Institucional de Agentes Indígenas de Saúde no Sistema Único de Saúde: um estudo de possibilidades. São Paulo, 2002. [Tese de Doutorado - Faculdade de Saúde Pública da USP]

O objetivo desse estudo foi analisar a construção das políticas de formação de agentes indígenas de saúde (AIS) no Brasil na década de 90 partindo da experiência da Escola Paulista de Medicina, atual Universidade Federal de São Paulo, no Parque do Xingu e dos princípios conceituais do Sistema Único de Saúde. O trajeto metodológico abrangeu pesquisa documental e vivências profissionais da pesquisadora. As fontes documentais foram relatórios sobre cursos e processos de capacitação de AIS, diários de viagem, legislação referente à política indigenista de saúde e educação profissional de nível técnico e fitas de vídeo sobre saúde indígena. As descrições obtidas compuseram um campo complexo de possibilidades de análise sendo aprofundados interdisciplinarmente os enfoques da educação crítica, antropologia da educação e política de saúde. Constatou-se que a formação dos AIS é necessária mas não chega a ser suficiente para ordenação da atenção básica de saúde indígena enquanto um sub-sistema do SUS. Caracteriza-se como um processo político-social e cultural recente e dinâmico, consonante com o paradigma solidarista das políticas sociais. Foram significativos os avanços conceituais e metodológicos na formação dos AIS e o impacto epidemiológico de suas ações no período estudado, enquanto que sua inserção institucional encontrase incipiente e conflituosa, refletindo embates de outros cenários e realidades. Recomenda-se o acompanhamento do diálogo interétnico e intercultural na área da saúde, e o desenvolvimento de mecanismos políticos de gestão que contemplem a institucionalização desses trabalhadores enquanto categoria sui generis no sistema de saúde e promovam a autonomia e cidadania indígena.

Descritores: agentes indígenas de saúde, saúde indígena, índios brasileiros, educação profissional , recursos humanos em saúde. 


\section{SUMMARY}

Oliveira LSS Formação e Inserção Institucional de Agentes Indígenas de Saúde no Sistema Único de Saúde: um estudo de possibilidades [Aboriginal Community Health Workers: ways of training and institutional insertion in brazilian unified health system]. São Paulo, 2002. [Tese de Doutorado - Faculdade de Saúde Pública da USP]

The purpose of this research was to analyze the aboriginal community health workers policies organization during the $90^{\circ}$ s, using as starting point the experience of the São Paulo Federal University, fomerly Escola Paulista de Medicina in the Xingu National Park, as well as ideas, notions and concepts of the Brazilian Unified Health System. The metodology used includes research in printed material and my own professional experiences. The researched material focused on: aboriginal health workers courses and continuing education reports, research travel logs, the current aboriginal health policies and health professional education courses, and video tapes on aboriginal people's health. The result and descriptions of this research led to a complex analytical and possibility field. As a result, health policies, critical education approach, and education anthropology were cross-analyzed in depth. As a conclusion, the organization of aboriginal health workers is necessary, but it not enough to provide the basic health support as part of the Brazilian Unified Health System. This is a recent and dynamic social-political process, consistent with social policies of community and solidarity principles. There was a significant conceptual and methodological improvement while creating and training the aboriginal health workers during the period of this research, although its institutional insertion is still and minimum antagonist, reflecting the shock of other scenarios and realities. It is recommended that the ethnical and cultural relations in the health area be follow up, that political management procedures legitimating the aboriginal health workers as a unique category in Brazilian Unified Health System be established, and the citizenship and autonomy of aboriginal peoples be promoted.

Keywords: aboriginal health peoples, community health workers, health professional education, human resources in health. 


\section{LISTA DE SIGLAS}

ACS Agente Comunitário de Saúde

AAISARN Associação de Agentes Indígenas de Saúde do Rio Negro

AEI Auxiliar de Enfermagem Indígena

AENI Auxiliar de Enfermagem não Indígena

AIDS Síndrome da Imunodeficiência Adquirida

AIS Agente Indígena de Saúde

AISB Agente Indígena de Saúde Bucal

ATIX Associação Terra Indígena Xingu

CIMI Centro Indigenista Missionário

CISI Comissão Intersetorial de Saúde Indígena

COSAI Coordenação de Saúde do Índio da Fundação Nacional de Saúde

DESAI Departamento de Saúde Indígena da Fundação Nacional de Saúde

DISEI Distritos Sanitários Especiais Indígenas

DSI Distrito Sanitário Indígena

DST Doenças Sexualmente Transmissíveis

EPM Escola Paulista de Medicina

ETS/MT Escola Técnica de Saúde de Mato Grosso

EVS Equipe Volante de Saúde

FNS Fundação Nacional de Saúde do Ministério da Saúde

FOIRN Federação das Organizações Indígenas de Saúde do Rio Negro

FUNAI Fundação Nacional do Índio do Ministério da Justiça

FUNASA Fundação Nacional de Saúde do Ministério da Saúde

HIV Vírus da Imunodeficiência Humana

LDBE Lei de Diretrizes e Base da Educação

MEC Ministério da Educação

MS Ministério da Saúde

OIT Organização Internacional do Trabalho

PACS Programa de Agentes Comunitários de Saúde

PI Posto Indígena

PIX Parque Indígena do Xingu 
PROFAE Projeto de Profissionalização de Trabalhadores da Área de Saúde PSF Programa de Saúde da Familia

SPI Serviço de Proteção ao Índio

SUS Sistema Único de Saúde

SUSA Serviços de Unidades Sanitárias Aéreas

UBS Unidade Básica de Saúde

UNIFESP Universidade Federal de São Paulo

USMA Unidade de Saúde e Meio Ambiente do Depto. de Medicina Preventiva da Universidade Federal de São Paulo 


\section{LISTA DE QUADROS}

Pg.

Quadro 1 Cronologia das legislações referentes a política indigenista de 15 saúde no Brasil. Brasil, 1994 - 1999.

Quadro 2 - Recursos Humanos do DISEI Xingu segundo função. Situação 67 em 2001 e meta para 2002.

Quadro 3 - Temas desenvolvidos e número de participantes dos cursos de formação de agentes de saúde, do DISEI Xingu, 1991 a 1996.

Quadro 4 - Cursos de saúde segundo periodo, tema e participantes. Xingu, 1997 a 2001.

Quadro 5 - Competências elaboradas pelo Grupo de Trabalho do 98 DEOPE/COSAI, 1999. 


\section{LISTA DE GRÁFICOS}

Pg.

Gráfico 1 - Participação dos profissionais por categoria nos cursos de formação, Xingu, 1995 a 2001.

Gráfico 2 - Vínculo dos trabalhadores indigenas de acordo com o contrato de trabalho, DISEI Xingu, 2001.

Gráfico 3 - Remuneração em reais dos trabalhadores indígenas do DISEI Xingu, de acordo com a função, 1998 - 2001.

Gráfico 4 - Situação de treinamento e trabalho dos AIS no Xingu, 1998 a 2001.

Gráfico 5 - Distribuição dos AIS do Xingu por etnia, 2001.

Gráfico 6 - Distribuição dos trabalhadores indígenas do Xingu segundo função, 1998 a 2001. 


\section{ANEXOS}

Anexo 1 Perfil de Morbi-mortalidade das populações indígenas do Brasil, 2001

Anexo 2 Mapa de Localilzação do Parque do Xingu e Perfil de Morbimortalidade das populações indígenas do Xingu, 1999

Anexo 3 Lei 9.836, de 23 de setembro de 1999

Anexo 4 Quadro de profissionais dos Distritos Sanitários Especiais Indígenas no Brasil, 2000

Anexo 5 Listagem de relatórios utilizados como fontes documentais. USMA/UNIFESP.

Anexo 6 Proposta Modular do Curso de Capacitação de Agentes Indígenas de Saúde. FUNASA, 2000

Anexo 7 Proposta de Curso de Formação de Auxiliar de Enfermagem para Indígenas. Escola Técnica de Saúde/ MT, 1999-2000

Anexo 8 Perfil dos AIS do Xingu

Anexo 9 Perfil dos AISB do Xingu

Anexo 10 Estrutura do DISEIX

Anexo 11 Organização dos DISEI e fluxo de atenção à saúde

Anexo 12 Planejamento dos cursos e supervisão dos AIS- Xingu

Anexo 13 Relação de Leis. Decretos e Pareceres consultados

Anexo 14 Listagem de desempenhos e auto-avaliação dos AIS

Anexo 15 Cronologia de viagens ao Xingu

Anexo 16 Formação de Agentes Indígenas de Saúde- Avaliação de Produtos

Anexo 17 Listagem de filmes e vídeos consultados 


\section{APRESENTAÇÃO}

Porque formar índios como profissionais de saúde?

A motivação para este estudo nasceu da necessidade responder parcialmente essa questão, mediante a reflexão sobre a prática de formação de agentes indígenas de saúde do Xingu desenvolvida por um grupo de profissionais da Universidade Federal de São Paulo (UNIFESP).

Novos desafios e mudanças na área de saúde indígena vêm impondo a necessidade de sistematizar e interpretar as muitas vivências sobre a profissionalização de indígenas que estão ocorrendo em diferentes realidades no país.

Esta pesquisa pretendeu fazer uma aliança entre a prática cotidiana do Projeto Xingu, um dos projetos extensão universitária mais antigos do país, o universo de conhecimento dos índios sobre saúde, as políticas de educação profissional e a produção científica na área da saúde indígena da década de 90. Trata-se de um trabalho interdisciplinar e exploratório, inserido no âmbito da saúde pública.

Os modelos assistenciais das políticas de saúde nacionais têm se mostrado comprometidos com muitos tipos de interesses. Nos últimos anos, várias experiências estão buscando novidade nos modos de pensar $\mathrm{e}$ produzir a saúde no Brasil. A construção de dispositivos de mudanças na saúde indígena encerra um potencial de contribuição com o todo que parte da especificidade étnica e cultural, um enfoque ainda pouco exercitado em nosso meio. 
O estudo privilegiou fontes documentais produzidas no período de 1990-2001 e a vivência de um grupo de agentes indígenas de saúde do Xingu, sujeitos únicos de sua história pessoal, cultural e profissional. Sua trajetória não seguiu um caminho linear, e sequer está concluída. Nela me inseri como pesquisadora, enfermeira e professora dos agentes indígenas de saúde (AIS), numa posição de escuta e descoberta. Chamado de estudo de possibilidades, o trabalho tenta delimitar um campo de análise complexa sobre o objeto da formação e trabalho de agentes indígenas de saúde (AIS). É uma tentativa de composição de uma visão ampla, multideterminada, diversa e que não deixe de ser simples e integrada.

A primeira parte da pesquisa procura situar a problemática do índio brasileiro, a evolução da política indigenista de saúde e sua interface com os processos de formação e inserção profissional de AIS. Segue-se com uma apresentação das possibilidades teóricas e percurso metodológico utilizado.

A segunda parte contém as descrições do lugar do estudo - O Parque Indígena do Xingu, - e as especificidades do processo de trabalho e do processo ensino-aprendizagem ali desenvolvidos. Apresenta, como contraponto, a proposta de formação do Ministério da Saúde e alguns elementos de avaliação dos programas de formação.

A análise, na terceira parte do texto, está centrada em três diferentes perspectivas teóricas, que são abordadas interdisciplinarmente: da educação crítica, antropologia da educação e política de saúde.

As considerações finais apontam a necessidade de novos estudos e diferentes olhares sobre a questão. Olhares que sejam simples e profundos, como o dos índios diante do conhecimento e da descoberta, um jeito de viver e fazer ciência que vem me encantando e desafiando há seis anos. 


\section{ÍNDICE}

1. Introdução

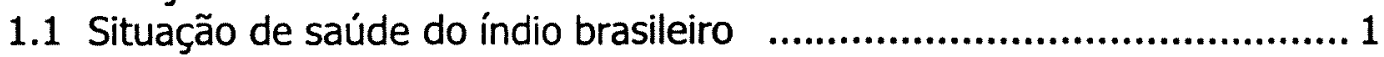

1.2 A política indigenista de saúde e o SUS ...................................... 11

1.3 A construção dos Distritos Sanitários Especiais Indígenas (DISEI)........ 16

1.4 Agentes Comunitários de Saúde e Agentes Indígenas de Saúde: caminhos e descaminhos da formação e institucionalização ................ 21

1.5 Especificidades da formação e trabalho dos Agentes Indígenas de Saúde................................................................................. 26

2. Aspectos teóricos e metodológicos ............................................ 34

2.1 Objetivos do estudo ............................................................. 34

2.2 Percurso metodológico ........................................................... 34

2.3 Lugar e sujeitos do estudo....................................................... 43

2.4 Aspectos éticos................................................................. 45

3. Descrições ................................................................................ 47

3.1 A formação de agentes indígenas de saúde na década de 90 ............ 47

3.2 Descrição do perfil de trabalho dos agentes indígenas de saúde em diferentes contextos: Amazonas, Colômbia e Venezuela...................... 52

3.3 Vida, trabalho e saúde no Xingu ................................................. 56

3.3.1 Um pouco de história........................................................ 56

3.3.2 O processo de trabalho e os recursos humanos no DISEI Xingu 63

3.3.3 Estrutura dos cursos de saúde: do treinamento à formação ...... 75

3.3.4 Organização dos conteúdos................................................. 79

3.3.5 O trabalho da supervisão ................................................. 95

3.4 A proposta de formação da FUNASA/Ministério da Saúde .................. 97

3.5 Elementos para avaliação dos programas de formação.....................100

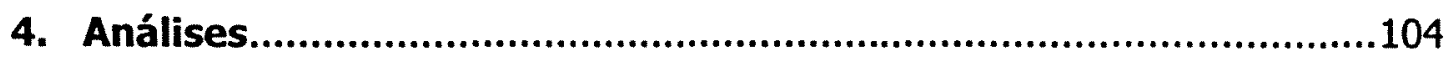

4.1 Dos enfoques de análise........................................................ 104

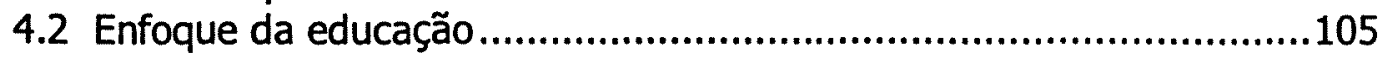

4.3 Enfoque da antropologia ....................................................119

4.4 Enfoque da política ....................................................... 128

5. Considerações Finais..................................................... 138

6. Referências Bibliográficas ............................................ 144

Anexos 


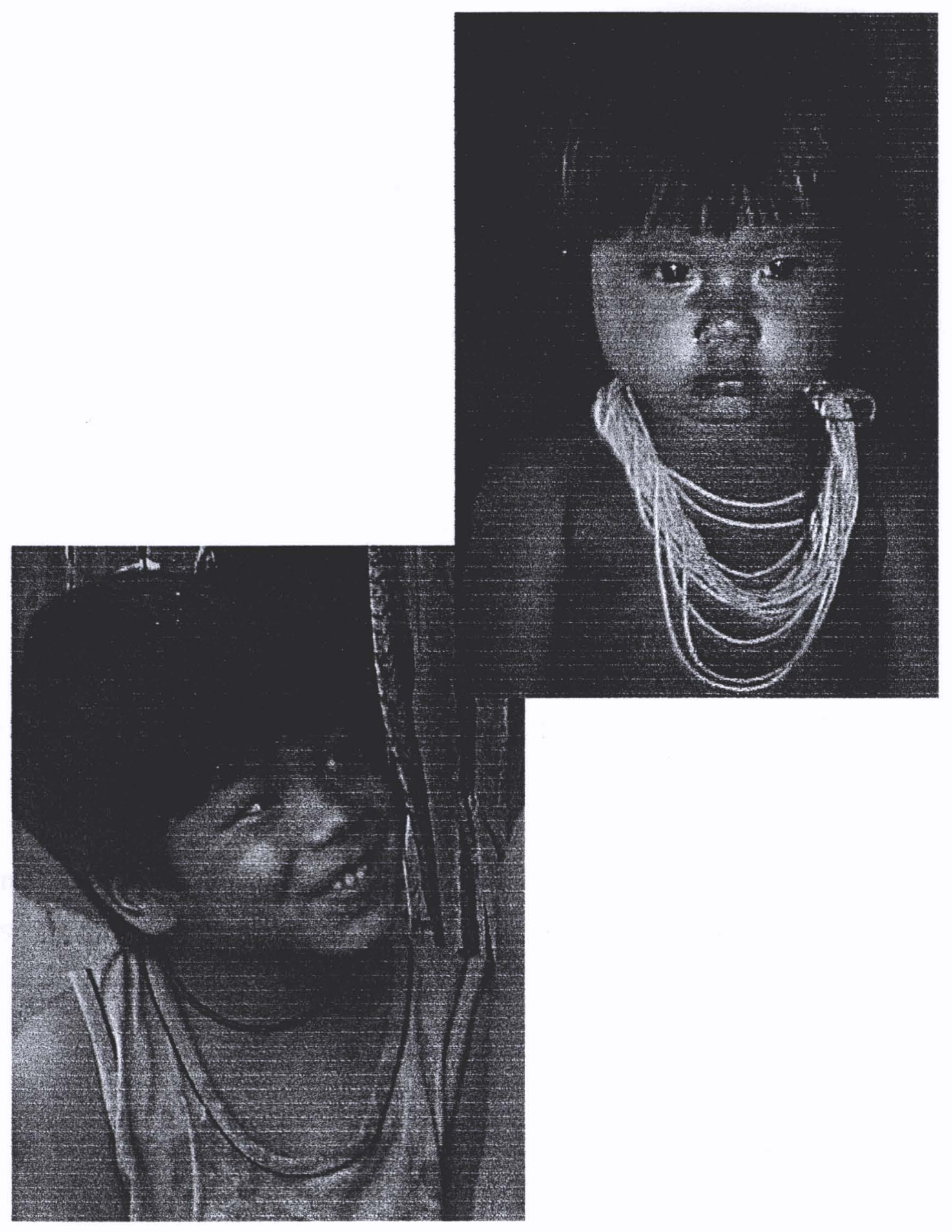




\section{INTRODUÇÃO}

\subsection{Situação de saúde do índio brasileiro}

"Antigamente, contam, os caraiba nos matavam. Fugindo deles, nossa gente mudou de aldeia muitas vezes. Aqui estão, veja, os descendentes. Porque vocês pegam nossa terra? Eu sei que vocês estão sobre nossas antigas aldeias. Os caraibas dizem de nós: depressa, peguem a terra deles! Eu pergunto como vocês tomam nossas terras, como vocês falam a nosso respeito. Escuta! Assim eram os caraiba antigamente, eu sei, os que iam matando nossos antigos. Agora nós amansamos os caraíba. Escuta!

Kujame Kuikuro, Alto Xingu, 1982

A relação das sociedades indígenas com a sociedade nacional sempre foi marcada por conflitos e violência. Ao ser estabelecido, o contato provocou profundas alterações entre os povos autóctones (ALMEIDA 1998).

A ocupação do continente americano pelos europeus, que no Brasil foi denominada de descobrimento, trouxe escravidão, destruição das aldeias, perda de territórios, desequilíbrio de ecossistemas e epidemias de doenças desconhecidas. Estima-se que na época do descobrimento, viviam no território brasileiro dentre 4 a 6 milhões de índios, representantes de mais de mil povos (RIBEIRO 1997). Desde a colonização até os dias atuais, assistiuse à dizimação de povos e culturas milenares. Mais devastadores do que o extermínio por guerras, foram as epidemias de doenças trazidas por europeus e africanos, como varíola, sarampo, gripe, tuberculose, varicela entre outras, que em função da ausência de imunidade específica dessas populações desencadearam uma verdadeira guerra biológica, com o desaparecimento de muitas etnias que veio perdurando por cinco séculos (GOMES 1991).

\footnotetext{
' Depoimento de Kujame Kuikuro à Bruna Franchetto, publicado em "A celebraçāo da história nos discursos cerimoniais Kuikuro. In: VIVEIROS DE CASTRO,E; CARNEIRO DA CUNHA, M. Amazónia:etnologia e História Indigena. NHII/USP/Fapesp, 1993. A denominaçāo caraiba, muito comum no Xingu, é referente ao homem branco, que veio de fora.
} 
No período entre 1900-80, cerca de 90 grupos foram extintos (CONFALONIERI 1993).

Tão chocante quanto o extermínio, entremeado por tentativas de integração e assimilação, talvez seja a condição atual de dependência econômica e social dos povos indígenas oriunda da profunda desigualdade existente. O trabalho de assistência à saúde situa-se nesse contexto, caracterizado por uma história de protecionismo e mediação de conflitos.

Já nos tempos do Brasil-colônia, a Igreja cumpria o papel de prover o cuidado do corpo e da alma dos índios. Os jesuítas se vangloriavam de atender os enfermos aplicando-Ihes mezinhas, sangramentos e os sacramentos na hora certa (GOMES 1991). O cuidado com o corpo consistia em uma estratégia de amansar os índios para facilitar sua incorporação na força de trabalho da lavoura e expedições armadas.

"Os portugueses persuadiam aos índios que se vendessem, e como por sua rudeza não entendiam quanto isto importava, vendiamse assim mesmo por uma roupeta de algodão, e uns calções que depois gastavam em serviço de seus próprios senhores, e quando depois entendiam o engano, se não era possível fugir, uns morriam de paixão, outros de perpétua desconsolação" .

ANTT, Manuscritos da Livraria, livro $1116^{\mathrm{ii}}$

Este desgaste humano constituiu uma forma de genocídio imposta, já identificada pelo Pe. Vieira em 1652, citada por RIBEIRO (1997):

" ... e toda aquela gente se acabou, ou nós a acabamos, em pouco mais de trinta anos... eram mortos dos ditos índios mais de dois milhões..."

A despeito do extermínio por doenças e epidemias que perduram há séculos, as formas de adoecimento e morte dos povos indígenas foram pouco estudadas.

\footnotetext{
ii Os Manuscritos da Livraria, do Arquivo Torre do Tombo ATT em Portugal, são uma coletânea de textos redigidos ao rei, contendo consultas sobre a administração colonial. Nesse caso, os religiosos capuchos consultam sobre as condições em que poderiam se servir do trabalho escravo exercido pelo índio. Citado por Rita Heloísa de Almeida, in: O Diretório dos Indios: um projeto de civilização no Brasil do século XVIII. Brasilia, ed. UNB, 1997.
} 
Ainda são escassos os dados disponiveis sobre os perfis de morbimortalidade dessas populações, situação agravada pela sub-notificação de doenças, discrepância de informações entre as áreas indígenas e a falta de consolidação e análise sistemática dos dados epidemiológicos. Não se dispõe de dados globais fidedignos sobre a situação de saúde dos índios brasileiros. O conhecimento sobre a realidade de cada etnia depende do padrão de contato e acesso aos serviços no qual se inclui o registro de informações epidemiológicas. Para COIMBRA e SANTOS (2000), existe uma intencionalidade na ausência de dados de saúde para as populações indígenas. É importante trabalhar para reverter a danosa "invisibilidade" demográfica e epidemiológica, já que um dos seus efeitos mais adversos é o de impedir a disponibilidade de dados confiáveis para evidenciar e corrigir as situações de desigualdade em saúde. As estimativas demográficas e de saúde vêm sendo feitas por agências governamentais, como a FUNAI e FUNASA, um pequeno número de secretarias estaduais e municipais de saúde e um incontável número de organizações não governamentais, com destaque ao ISA - Instituto Sócio Ambiental e ao CIMI - Centro Indigenista Missionário, da igreja católica (ISA 2000).

Embora precários, os dados disponiveis indicam taxas de morbimortalidade três a quatro vezes maiores do que a média brasileira (MINISTÉRIO DA JUSTIÇA 1998). É alta a incidência de infecções respiratórias, gastrointestinais agudas, malária, tuberculose, DST e carências nutricionais, evidenciando um quadro que poderia ser revertido com ações contínuas de vigilância à saúde e programas de atenção básica à saúde (MINISTÉRIO DA SAÚDE 2001b).

Um estudo referente às áreas indígenas do Mato Grosso, realizado no periodo de 1993-1995 iii constatou que dentre as causas de morte destacavam-se as infecções respiratórias agudas, gastroenterocolites e

\footnotetext{
iii Escola Paulista de Medicina/Unidade de Saúde e Meio Ambiente. Relatório de Consultoria PNUD/PRODEAGRO. São Paulo, 1995.
} 
desnutrição, representando $76,2 \%$ dos óbitos. Quanto à faixa etária, havia uma concentração de $58,9 \%$ de mortes entre 0 e 5 anos. Um consolidado dos relatórios de 22 das 47 administrações da FUNAI em 1998, abrangendo uma população de setenta mil indivíduos registrou 466 óbitos, metade entre menores de cinco anos, sendo as doenças respiratórias a principal responsável por esses índices (FUNAI 1998). Os agravos mais comuns, além das infecções respiratórias e doenças diarréicas foram malária, tuberculose, doenças imunopreveniveis e doenças sexualmente transmissíveis. As causas externas constituíram a terceira causa de mortes, cerca de $15 \%$ do total de óbitos, atingindo principalmente as regiões do Mato Grosso do Sul e Roraima (FIGUEROA 2000).

Nos últimos anos os males sociais comuns entre as populações urbanas de baixa renda têm aumentado significativamente entre os índios. Destacam-se dentre eles o alcoolismo, gravidez precoce, uso de drogas e o suicídio, principalmente entre os mais jovens, comprometendo severamente a estrutura social dessas comunidades.

Em algumas populações a vulnerabilidade é extrema. Entre os Yanomami de Roraima, o coeficiente de mortalidade infantil em 1998 foi de 141/1000. A tuberculose passou de 450/100.000 em 1991 para 881,4 por 100.000 em 1994. Talvez seja esta a doença de maior impacto dentre as populações indígenas de todo o país, respondendo por cerca de $22,7 \%$ dos óbitos dentre as doenças transmissíveis, o dobro da taxa mundial específica para a tuberculose (BARUZZI 2000).

Dentre as carências nutricionais, destacam-se a anemia e desnutrição. Crianças indígenas terenas, acompanhadas por RIBAS e col. (2001), apresentaram déficits nutricionais de $8 \%$ no índice peso-para idade, $16 \%$ no índice estatura-para- idade e $5 \%$ de obesidade. 0 mesmo estudo evidenciou proporções elevadas de retardo de crescimento em comparação a população brasileira como um todo. 
Entre os indios Karitiana de Rondônia, a anemia atinge $30,4 \%$ da população e a prevalência de tuberculose é 34 vezes maior do que o encontrado na população em geral da região Norte (FERRARI 1995).

As DST e a infecção por HIV/AIDS também é um agravo preocupante pela rápida ascensão. De 1998-2000, foram notificados 36 casos de AIDS e 8 óbitos entre índios, refletindo a interiorização da doença, (CNS 2000). O curto período entre o diagnóstico e o óbito revela as dificuldades de tratamento e compreensão da rede de transmissão e formas de prevenção da AIDS e das demais doenças sexualmente transmissíveis.

Não se pode deixar de mencionar a cárie e as doenças periodontais como relevantes no perfil de morbidade destas populações. ARANTES em 1998, encontrou entre os indios Xavantes em Mato Grosso apenas 8,7\% da população livre da cárie dental, sendo rápida a deterioração das condições de saúde bucal, ao inverso do que vem ocorrendo no Brasil como um todo.

As doenças transmissiveis estão em decréscimo em algumas regiões, mas o perfil de morbidade vem sendo modificado com o aumento de outros agravos, como neoplasias, acidentes e síndromes congênitas (Anexos 1 e 2). A presença das chamadas "doenças ocidentais", de evolução crônica e não transmitidas, como a hipertensão, diabetes e outros distúrbios cardiovasculares ainda é incipiente, mas já começa a preocupar porque está relacionada à rápida mudança de hábitos alimentares, como o aumento do consumo de alimentos industrializados, seguindo o padrão de transição epidemiológica já evidenciado entre os índios da América do Norte (YOUNG 1991). A obesidade, fator de risco para hipertensão e diabetes ausente na população do Xingu nos anos 70 em 1999 foi identificada em 36\% de uma amostra composta por 62 indivíduos (BARUZZI 2000 ).

Alguns aspectos positivos, no entanto, também podem ser identificados. 
No Parque Indígena do Xingu, onde existe assistência médica sistemática e atuação expressiva de agentes indígenas de saúde, os coeficientes de morbi-mortalidade estão mais próximos e até melhores do que os encontrados nos municípios da região. O perfil de morbidade é semelhante as demais áreas indígenas da Amazônia, mas a mortalidade é muito mais baixa. Predominam as doenças infecciosas respiratórias agudas e doenças diarréicas, somando $67 \%$ das ocorrências de morbidade registradas no ano de 1998. No ano seguinte, as ocorrências respiratórias agudas responderam por $34,9 \%$ dos 3574 atendimentos, seguidas pelas doenças diarréicas, com $20,5 \%$ ou 2097 atendimentos, malária $11 \%$ ou 117 casos e doenças de pele com $5 \%$ ou 504 atendimentos. A primeira causa de óbitos no período foi neoplasia - $22 \%$, contra $17 \%$ das mortes por doenças infecciosas (Anexo 2). Nos últimos anos, a mortalidade por doenças transmissiveis, evitáveis por atenção primária à saúde diminuiu em até $40 \%$ (USMA/UNIFESP 2000 ).

Entre os Yanomami, a situação de vulnerabilidade também vem sendo minimizada. Os coeficientes de mortalidade estão se reduzindo expressivamente. A média mantida entre 1991-99, de 19,8/1000, passou para 9,4/1000 no ano de 2000 , provavelmente devido à continuidade da assistência nas aldeias nos dois últimos anos, e presença maciça de profissionais de saúde.

Analisando o perfil demográfico das populações indígenas encontramos expressivas alterações. Há um crescimento global nos últimos 25 anos, embora alguns povos ainda estejam ameaçados de extinção. A taxa de crescimento populacional entre os índigenas é de $4 \%$ ao ano, quase três vezes maior do que a média nacional. Em cinco anos, a população aumentou $17 \%$ (ISA, 2000).

Os povos indígenas que sobreviveram aos séculos de extermínio vêm se estabilizando, crescendo em número e aumentando sua participação na 
condução de políticas referentes à sua educação, saúde, território e na participação da sociedade como um todo constituindo um movimento de crescente visibilidade política na América Latina.

A atual discussão sobre a diversidade étnica e cultural na sociedade brasileira vem situando o movimento indígena dentre os movimentos sociais postulantes do reconhecimento da diversidade cultural que não se confunde com a desigualdade (OLIVEIRA 2000).

Para GOMES (1991) frente a esta trajetória histórica, não seria conseqüente afirmar que os índios afinal sobreviveram. Este autor identifica este fenômeno não como de sobrevivência, mas de reminiscência.

A população indígena do Brasil contrasta com o grande contingente de populações tribais na Ásia e com a expressão demográfica dos grupos indígenas nas Américas. Em 1990, O Instituto Indigenista Interamericano estimava, por exemplo, uma população indígena de 7,8 milhões de pessoas no México, 8,4 milhões no Peru, 5,8 milhões no Equador, 2 milhões nos Estados Unidos, 1 milhão no Canadá, 800 mil no Chile, 500 mil na Colômbia,400 mil na Venezuela, 350 mil na Argentina, 160 mil na Nicarágua, 140 mil no Panamá e 100 mil no Paraguai (CORDEIRO 1999). Atualmente, existem 250 povos indígenas do Brasil, uma população estimada de 350.000 pessoas falantes de mais de 170 línguas, a maioria delas filiadas a quatro troncos principais (Tupi, Jê, Aruak, Karib). Vivem em 556 terras indígenas, muitas não demarcadas, em 23 Estados da Federação, sendo 60\% na Amazônia e uma pequena parcela nas periferias urbanas. (ISA 2000, MINISTÉRIO DA SAÚDE 2000b). Cada um desses povos tem diferentes maneiras de entender e se organizar diante do mundo, e sua experiência de contato com a sociedade nacional varia bastante: desde 0 isolamento total até a convivência de cinco séculos.

Qual a importância dos índios no país atualmente? Em muitos aspectos o Brasil contemporâneo é mais indigena do que normalmente se 
admite. Ao contrário do que antes se supunha, a sobrevivência residual de grupos indígenas culturalmente distintos tende a não se desfazer no corpo social do país. Já na década de 60 percebia-se que, mesmo transfigurados etnicamente no contato "os índios permanecem índios", expressão de Darci Ribeiro, que nessa época já identificava uma crescente simpatia pelos índios entre os brasileiros (RIBEIRO 1997). Para o antropólogo, os índios seriam reconhecidos parceiros na construção do país, partícipes do potencial humano brasileiro e da formação da identidade nacional.

Uma pesquisa realizada pelo IBOPE em 2000, demonstrou que a maioria dos brasileiros tem uma imagem positiva dos índios, sendo que $88 \%$ consideram que eles conservam a natureza e vivem em harmonia, têm um modo próprio de trabalhar e não são preguiçosos; $89 \%$ afirmam que eles não são ignorantes, apenas sua cultura é diferente. (ISA 2000). Parece que no século XXI, os caraíbas estão sendo finalmente amansados pelos índios.

As posturas políticas de paternalismo e pacificação, de inspiração positivista que intermediaram a relação interétnica desde os tempos de criação do Serviço de Proteção ao Índio (SPI), em 1910, e foram antagonizadas por posições etnocêntricas de assimilacionismo e integração impostas, vêm cedendo a um incipiente diálogo intercultural (MENDONÇA 1996, COSTA 1987, OLIVEIRA 2000).

Para PELLEGRINI (1998), "A situação atual dos índios brasileiros é bastante peculiar; eles não são apenas um segmento mais vulnerável aos danos de saúde e problemas sociais engrossando os segmentos de pobreza e exclusão social; são também donos das maiores riquezas da nossa época, tanto no sentido da riqueza econômica quanto cultural." 
A maior parte dos povos indígenas do país vive na zona "rural" iv do Norte e Centro Oeste, onde o acesso aos serviços de saúde é bastante precário, devido a aspectos logísticos e operacionais e particularidades sócio-culturais.

O quadro sanitário já explicitado, que em geral caracteriza as áreas indígenas, reflete a desassistência a que esses povos foram históricamente submetidos, situação que poderia ser significativamente revertida com medidas simples no âmbito da atenção primária à saúde. Essa trajetória, entremeada por experiências isoladas de trabalho mais consistente de saúde, configura uma atuação desordenada e ineficaz de diversas instituições, além do próprio governo: missões religiosas, universidades, organizações não governamentais brasileiras e internacionais, constituindo uma verdadeira "salada de organizações" (FERRARI 1995).

A prática de assistência à saúde indígena do órgão competenteinicialmente o Serviço de Proteção ao Índio e posteriormente a Fundação Nacional do Índio, do Ministério da Justiça - criada em 1967, caracterizou-se pela intervenção local de equipes de saúde, denominadas EVS - equipes volantes de saúde. O modelo pressupunha visitas periódicas às aldeias, que deveriam ser dotadas de um mínimo de infra-estrutura de saúde.

Baseadas em um modelo vigente desde os anos 50, dos Serviços de Unidades Sanitárias Aéreas (SUSA), as EVS realizavam atendimentos nas comunidades indígenas, prestando assistência médica, aplicando vacinas e supervisionando o trabalho do pessoal local, geralmente auxiliares $\mathrm{e}$ atendentes de enfermagem (FUNASA 2000). Com o decorrer dos anos as EVS foram se esvaziando, devido principalmente à falta de recursos, que dificultava a mobilidade das equipes, afastando os profissionais "brancos"

\footnotetext{
${ }^{\text {iv }} \mathrm{O}$ uso do termo rural para designar povos e áreas indigenas é polêmico. Alguns autores utilizam a palavra sertão, com o mesmo significado. Neste trabalho, optou-se pelo uso da expressão rural entre aspas, no sentido de oposição ao contexto urbano.
} 
das aldeias, que se deslocaram para os centros urbanos, desmotivados pela precariedade das condições de trabalho.

A formulação de uma política setorial de saúde indígena, capaz de atender a diversidade da situação, advém da necessidade de se fazer oposição a uma trajetória histórica excludente, concebendo formas de relação entre Estado e Sociedade capazes de promover processos de inclusão, participação e emancipação social que considerem a diversidade cultural. Nesse contexto, está posto o debate político do componente saúde para as populações indígenas, e a inserção de profissionais como sujeitos do trabalho. Dentre eles, destaca-se a figura do agente indígena de saúde (AIS), geralmente jovens do sexo masculino, que dominam a língua portuguesa, conhecem algumas práticas do sistema tradicional de cura, têm influência nas suas comunidades e cuja relevância da atuação aumenta na medida em que os órgãos oficiais de assistência vem desconcentrando e descentralizando suas ações de saúde, direcionando a base do sistema de atenção para as aldeias indígenas. Em 1999, o Ministério da Saúde estimava a existência de 4 mil AIS em atividade no país (MINISTÉRIO DA SAÚDE, 1999c). O trabalho deles é bastante complexo, pois além do exercício da mediação cultural existem demandas concretas de intervenção na assistência, e de ações de promoção da saúde nas comunidades.

Os demais profissionais de saúde e entidades não governamentais também parecem assumir este papel mediador, fazendo interlocução entre as demandas dos povos indígenas e a sociedade nacional, minimamente direcionando-as para os órgãos competentes. O exercício de decodificar a estrutura burocrática do Estado e cobrar responsabilidades sociais posiciona esses atores como participantes ativos de um movimento político, com diferentes expressões individuais, coletivas, profissionais e institucionais. 
É nesse cenário que se colocam as perguntas: Quem é o agente indígena de saúde? Qual a sua inserção no sub-sistema de saúde indígena? Como vem ocorrendo sua formação e trabalho?

Esse estudo foi delineado tendo como objeto a formação e trabalho dos agentes indígenas de saúde. Sua finalidade é contribuir na delimitação de um campo de possibilidades de análise temática da sua preparação e inserção no âmbito do Sistema Único de Saúde - SUS.

Para melhor referenciar o contexto de trabalho dos AIS, será traçado um panorama sobre a política indigenista de saúde, a construção dos Distritos Sanitários Especiais Indígenas, e as experiências de capacitação e inserção institucional de agentes de saúde desenvolvidas nos anos 90 .

\subsection{A política indigenista de saúde e o SUS}

"Agora a Funai tá cansada, ela entregou a saúde na mão dos paulistas. Deixa ela descansar um pouco, deixa o distrito vir, a Funasa vir, ela é criança ainda, tá aprendendo a andar, mas vai cuidar da saúde do indio".

Jakalo Kuikuro, 1999.

Datam de 1985 os primeiros esforços de agregação de prestadores de serviços de saúde para povos indígenas e entidades de apoio a fim de formular uma proposta de organização da saúde. Este esforço integrador fez parte do Movimento da Reforma Sanitária, que caminhava para a concepção do modelo assistencial do SUS, regido pelos princípios da universalidade, acessibilidade, eqüidade e integralidade.

Na VIII Conferência Nacional de Saúde, em 1986, foi aprovada a convocação da I Conferência Nacional de Saúde do Índio, que ocorreu no mesmo ano e estabeleceu as bases para um sub-sistema específico de saúde indígena (MENDONÇA 1999). 
Em 1988, a nova Constituição reconheceu e garantiu aos índios proteção à sua organização social, crenças e tradições e o direito da atenção diferenciada e integrada à saúde, sob responsabilidade da União. ${ }^{\vee} \mathrm{Na}$ esfera da saúde, legislações específicas (Lei no 8080/90 e Lei no 8142/90) regulamentaram a prestação de serviços de saúde as comunidades indígenas como dever do Estado.

Dada a abrangência das competências legais das duas instituições federais afetas à problemática - FUNAI e FNS ${ }^{\mathrm{vi}}$, ficou ainda mais conflituoso e difícil definir as atribuições e responsabilidades sobre a saúde do índio.

O Decreto n० 23, de fevereiro de 1991, transferiu para o Ministério da Saúde a coordenação das ações de saúde destinada aos índios, referindo-se oficialmente pela primeira vez aos Distritos Sanitários Especiais Indígenas (DISEI) como instância estratégica de organização de serviços de saúde para populações indígenas.

Neste mesmo ano foi criada a CISI - Comissão Intersetorial de Saúde do Índio, através da Resolução do Conselho Nacional de Saúde 11/91, com o objetivo de elaborar e recomendar políticas de saúde para os povos indígenas a nível nacional e acompanhar sua implementação.

A IX Conferência Nacional de Saúde, realizada em 1992, realçou a importância dos DISEI que deveriam ser ligados diretamente ao Ministério da Saúde e administrados por Conselhos de Saúde com participação indígena. A II Conferência Nacional de Saúde para os Povos Indígenas, em 1993, teve por objetivo a definição das diretrizes da Política Nacional de Saúde para Povos Indígenas, em conformidade com o processo de consolidação do SUS e sua incorporação à um sub-sistema diferenciado de saúde. Merecem destaque nessa Conferência as considerações feitas sobre o caráter

\footnotetext{
"República Federativa do Brasil. Constituição Federal de 1988. Capítulo VIII - Dos Índios.

${ }^{v i}$ A FNS passou a ser denominada por FUNASA em 1999. As siglas estão mantidas de acordo com a citação da fonte original.
} 
descentralizado do SUS, viabilizado pelo processo de municipalização que, no caso das populações indígenas, acordam com os preceitos constitucionais definindo a responsabilidade indelegável da União para a sua assistência.

Assim, a responsabilidade da saúde indígena foi mantida no nível federal, mas passou a admitir contribuições complementares dos estados, municípios, outras instituições governamentais e não governamentais no custeio e execução de suas ações.

A II Conferência ressaltou, ainda, que a descentralização possibilitaria a tomada de decisões com a participação indígena ${ }^{\text {vii. }}$.

O modelo de atenção à saúde proposto contemplaria a abordagem diferenciada e global, abrangendo a assistência à saúde, saneamento básico, nutrição, habitação, meio ambiente, demarcação de terras e integração institucional. A população indígena deveria ser assistida pelo SUS a nível local, regional e nos centros especializados de acordo com suas necessidades, compreendendo os níveis de atenção primária, secundária e terciária à saúde. Dentro desta lógica organizativa, os DISEI se apresentavam como base do modelo assistencial, com autonomia de gestão administrativa, orçamentária e financeira, configurando uma instância estratégica para organização dos serviços de saúde, vinculadas as instâncias do SUS regional.

A aldeia indígena seria a base do sistema, e o trabalho do AIS o contato efetivo entre a comunidade e o SUS, articulado às áreas indígenas por um sistema hierarquizado e diferenciado nos níveis ambulatorial e hospitalar.

Nessa época o dep. Federal Sérgio Arouca apresentou na Câmara Federal um Projeto de Lei de Saúde Indígena, que remontava aos idos da VIII Conferência Nacional de Saúde, aprovado na Câmara Federal em 1994.

vii Ministério da Saúde. Relatório Final da ll Conferência de Saúde dos Povos Indigenas, 1993. 
$\mathrm{Na}$ década de 90 , concomitante aos embates jurídicos, a política neoliberal trouxe para o campo da assistência social um desmonte progressivo da máquina administrativa federal, visando o enxugamento do Estado, a fim de se atender as prerrogativas da Reforma Administrativa do MARE, viiicom reflexos bastante negativos na esfera da assistência à saúde das populações indígenas, que ficaram praticamente abandonadas, com recrudescimento de várias doenças, principalmente tuberculose, malária e DST.

Na contramão das conquistas até então alçadas, o Decreto 1141 de maio de 1994 revogou o Decreto 23/91, devolvendo as atribuições da saúde indígena para a FUNAI. A intervenção da Comissão Intersetorial do Ministério da Justiça, presidida pela FUNAI e composta por diversos ministérios levou a Resolução no 2, dividindo as atribuições da assistência médica para a FUNAI e do controle de endemias para a FNS, atual FUNASA.

Nos anos seguintes, diversas discussões passaram a ocorrer nas instâncias federais do poder legislativo, executivo e judiciário, com desdobramentos vários, gerando um movimento de conflitos e disputas caracterizado por avanços e retrocessos. A Lei Arouca, como ficou conhecida, tramitou por várias comissões e relatorias, sendo apresentada ao Senado em 1997, aprovada em abril de 1999, e sancionada em 23 de setembro de 1999 como Lei no. 9836, (Anexo 3) que acrescentou dispositivos ao cap.V- Título II da Lei no. 8080, do Sistema Único de Saúde e passou a vigorar instituindo o Sub-sistema de Atenção à Saúde Indígena.

A cronologia estabelecida no quadro 1 procura refletir essa dinâmica e facilitar a compreensão desse processo.

\footnotetext{
viii MARE- A Reforma do aparelho de Estado, propostas de emendas e exposiçāo de motivos. Ministério da Administração Federal e Reforma de Estado, 1995.
} 
QUADRO 1 - Cronologia das legislações referentes a política indigenista de saúde. Brasil, 1994- 1999.

\begin{tabular}{|c|c|}
\hline ANO & LEGISLAÇÃO \\
\hline 1994 & $\begin{array}{l}\text { - Projeto de Lei no } 4681 \text {, de autoria do dep. Sérgio Arouca, dispõe do } \\
\text { funcionamento de serviços de saúde para populações indígenas. }\end{array}$ \\
\hline 1996 & $\begin{array}{l}\text { Projeto de Lei no } 2057 \text {, dispõe sobre o estatuto das sociedades indígenas, } \\
\text { vinculando a saúde a FNS, com participação do órgão indigenista }\end{array}$ \\
\hline 1998 & $\begin{array}{l}\text { A Lei n० } 9649 \text { de } 25 / 05 / 98 \text { que dispõe sobre a Organização da Presidência da } \\
\text { República e dos Ministérios, divide as funções relacionadas à assistência à saúde } \\
\text { das comunidades indigenas entre a FUNAI e a FNS. A primeira para assistência } \\
\text { médica e a segunda para controle de endemias. }\end{array}$ \\
\hline & $\begin{array}{l}\text { - A Medida Provisória no } 1911-8 \text {, de } 29 / 7 / 99 \text {, reeditada em } 27 / 8 / 99 \text { e } 24 / 9 / 99, \\
\text { transfere as atribuições relativas à assistência à saúde dos índios para a FNS, } \\
\text { incluindo a transferência de recursos humanos e outros bens destinados à } \\
\text { saúde do índio da FUNAI para a FNS. } \\
\text { - A Medida Provisória no } 1911-10 \text { inclui o acompanhamento pelo Ministério da } \\
\text { Justiça das ações desenvolvidas na área da saúde indígena. } \\
\text { - A Portaria conjunta no } 7 \text {, dos Ministérios da Justiça e da Saúde dispõe sobre a } \\
\text { transferência de quadros de pessoal, bens e acervo da área de assistência à } \\
\text { saúde da FUNAI para a FNS. } \\
\text { O Decreto no. } 3156, \text { de } 27 / 08 / 99 \text {, dispõe sobre as condições de prestação de } \\
\text { assistência à saúde das comunidades indígenas no âmbito do SUS. Assegura os } \\
\text { serviços de atendimento básico nas terras indigenas pelos Distritos Sanitários } \\
\text { Especiais Indígenas. } \\
\text { Publicação da Lei no. } 9836, \text { de } 23 / 9 / 99, \text { que acrescenta dispositivos a Lei do } \\
\text { SUS, } 8080 / 90, \text { instituindo o Subsistema de Atenção à Saúde Indígena. } \\
\text { A Portaria no. } 852, \text { de } 30 / 9 / 99, \text { do Ministério da Saúde, cria os Distritos } \\
\text { Sanitários Especiais Indígenas como unidades de execução das ações } \\
\text { destinadas à promoção, proteção e recuperação da saúde do índio, objetivando } \\
\text { o equilibrio bio-psico-social. Reconhece o valor e a complementaridade das } \\
\text { práticas de medicina indígena, segundo as peculiaridades e perfil epidemiológico } \\
\text { de cada comunidade. }\end{array}$ \\
\hline
\end{tabular}

A discussão sobre a unificação dos prestadores de serviços de saúde indígena e a construção dos DISEI começou a se delinear como um caminho político no final do ano de 1998. Desde então, vários esforços vêm sendo despendidos na busca de novas composições da esfera político administrativa, apontando para uma incipiente e polêmica construção dos DISEI. 
A Portaria Ministerial no $852 / 99$, elenca as prioridades na área da assistência, presentes no art. $2^{\circ}$ : ações de redução da mortalidade, em especial a materno - infantil, a interrupção do ciclo de doenças transmissíveis, o controle da desnutrição, cárie dental e doença periodontal, e a restauração de condições ambientais cuja violação se relacione ao surgimento de doenças e outros agravos à saúde. Salienta ainda a assistência integral prestada por órgãos públicos e parcerias como organizações indígenas e outras da sociedade civil, e a participação das comunidades indígenas envolvidas na elaboração da política de saúde indígena. Neste mesmo artigo, o Parágrafo Único assegura os serviços de atendimento básico nas terras indígenas e remete a organização das atividades de atenção à saúde desses povos no âmbito do SUS aos DISEI.

No âmbito administrativo ocorreram vários re-arranjos funcionais, em consonância ao processo de implantação dos DISEI. Em 25/8/99, a Portaria Conjunta $n^{\circ} 7$, dos Ministérios da Justiça e da Saúde, dispõe sobre a transferência de quadros de pessoal, bem móveis e acervo da área de assistência à saúde da FUNAI para a FNS. 0 enfoque que interessa a esse estudo será a compreensão dos DISEI como processo social, e a participação do AIS neste novo contexto institucional (Anexo 13).

\subsection{A construção dos Distritos Sanitários Especiais Indígenas} (DISEI)

"Eu estou gostando muito! Me parece fácil, mas é muito difícil! É muito cansativo construir um distrito de saúde. Mas uma coisa importante para toda comunidade xinguana, eu acho que só a sistematização do trabalho em saúde é que podemos tentar melhorar a saúde aqui no Xingu.

Ayumã Kamaiurá, auxiliar de enfermagem indigena do DISEI Xingu, 1998 
As primeiras ações sistematizadas de combate à epidemias entre os índios iniciaram-se na segunda metade do século XX, promovidos pelo SPI, através de vacinações e do controle de malária e tuberculose. São conhecidos o trabalho do médico sanitarista Noel Nutels, no combate à tuberculose a instalação das equipes volantes de saúde da FUNAI, por Sadok de Freitas e também a atuação da Escola Paulista de Medicina no Parque do Xingu, através de um programa de atenção integral à saúde que compreendia medidas como vacinação e diagnóstico de saúde das comunidades (BARUZZI 1989, GOMES 1991).

Do ponto de vista sanitário, concordamos com MERHY (1997), na avaliação de que esses modos de trabalho, denominados pelo autor de campanhista e programático, são típicos das intervenções em saúde pública em nosso meio e apesar de terem impacto imediato, são susceptíveis à descontinuidades e fragilidades políticas e institucionais.

Desde o final dos anos 70, profissionais de saúde que atuavam entre os índios e compuseram o chamado movimento indigenista sanitário apontavam essas fragilidades e recomendavam reformulações para o trabalho nas áreas indígenas através da estratégia de organização de serviços de saúde assegurando a continuidade, planejamento, informação e avaliação da assistência (VARGA 1992).

Os distritos sanitários são uma expressão do modelo de sistemas locais de saúde e foram implantados no Brasil a partir de 1987, sendo ampla a literatura sobre as experiências desenvolvidas em municípios de porte variado. Compreende-se que na especificidade indígena - uma realidade não urbana em sua quase totalidade - a criação e desenvolvimento dos distritos sanitários seja um processo social de mudanças das práticas sanitárias do SUS, capaz de potencializar a solução de alguns desafios específicos dos povos indígenas e "rurais". A construção dos distritos parece atender a 
necessidade latino-americana de constituição de sistemas locais de saúde (MENDES 1994, ATHIAS e MACHADO 2001 ).

Destacam-se para essa constituição os critérios epidemiológicos e um desenho geográfico-social, uma abordagem diversa do desenho normativo e burocrático que por vezes se impõe na área de planejamento em saúde. A noção de Distrito Sanitário Indígena está centrada na organização de serviços de saúde pertencentes a cada realidade étnica, de forma que as ações sejam eficazes para determinada população indígena. O trabalho no DISEI fundamenta-se no planejamento estratégico e pretende ser multiprofissional, multiinstitucional e intercultural, com a possibilidade de desenvolver um grande potencial igualitário e de diálogo interdisciplinar.

A proposta dos DISEI que veio sendo pautada ao longo do processo de reforma sanitária no Brasil como um sub-sistema de saúde diferenciado, deveria contemplar a atenção básica e a promoção da saúde dentro das áreas indígenas, articulando-se ao SUS nas instâncias regionais. Nesse modelo, passam a ter relevância ações como a vigilância epidemiológica, do meio ambiente e a educação em saúde, situadas em um novo contexto cultural que inclui questões como o etnodesenvolvimento e a sustentabilidade social (MINISTÉRIO DA SAÚDE 1999b).

Um dos aspectos polêmicos e que precisa ser melhor compreendido, é o do território distrital. A nova abordagem extrapola os limites geográficos e administrativos dos municípios, referência utilizada na organização de serviços do SUS. Outro aspecto fundamental diz respeito à participação indigena, que tem reproduzido a estrutura de controle social referente ao SUS, com conselhos locais e distritais de saúde e necessita de adaptações. A difusão da ideologia dos DISEI como um processo de construção social democrático e participativo, base de um sub-sistema específico de atenção à saúde indígena, proporcionou uma série de encontros em todo o país promovidos pela FUNASA e criou um novo espaço de debate político 
envolvendo lideranças indígenas, prestadores de serviços governamentais e não governamentais e outros. Essas questões vêm sendo discutidas com vivacidade nos últimos anos. A concordância do temário "Efetivando o SUS: acesso, qualidade e humanização da saúde", da XI Conferência Nacional de Saúde, (realizada em dezembro de 2000) e da III Conferência Nacional de Saúde Indígena (ocorrida em maio de 2001) que debateu o processo de implantação dos DISEI e o acesso, qualidade e humanização do novo subsistema, indicam que a organização da saúde indígena já faz parte da realidade sanitária brasileira (MINISTÉRIO DA SAÚDE 2001c).

A experiência de implantação dos DISEI vem demonstrando que a participação indígena pode conferir ao processo de construção do SUS uma prática de inclusão social na qual a busca de direitos, autonomia, pertencimento e identidade cultural vão se resgatando, construindo e desconstruindo com muita pertinência, constituindo um exemplo histórico da chamada cidadania de sobrevivência por VALLA (1994).

Segundo a FUNASA, a implementação da nova Política Nacional de Saúde Indígena é uma construção coletiva iniciada em agosto de 1999 e efetivada na III Conferência Nacional de Saúde Índígena, em 2001, uma experiência ousada de implantação simultânea de 34 distritos, carregada de enormes dificuldades, resistências, incompreensões e erros (MINISTÉRIO DA SAÚDE, 2001c).

A Política Nacional de Atenção à Saúde dos povos indígenas, publicada em dezembro de 2000 contempla as seguintes diretrizes para o acesso à atenção integral à saúde (MINISTÉRIO DA SAÚDE 2000a):

- organização dos serviços de atenção à saúde na forma de Distritos Especiais e Pólos-base, no nível local, onde a atenção primária e os serviços de referência se situam; 
- preparação de recursos humanos para atuação em um contexto intercultural;

- monitoramento das ações de saúde dirigidas aos povos indígenas;

- articulação dos sistemas tradicionais indígenas de saúde;

- promoção do uso adequado e racional de medicamentos;

- promoção de ações específicas em situações especiais;

- promoção da ética na pesquisa e nas ações envolvendo comunidades indigenas;

- promoção de ambientes saudáveis e proteção da saúde indígena e

- controle social.

A implantação dos DISEI envolveu números significativos: custos de $R \$ 62$ milhões em 1999 e R\$106 milhões em 2000; 45 convênios de terceirização da atenção à saúde indígena, celebrados com municípios, organizações indígenas, ONGs, missões religiosas e universidades; cerca de 4 mil profissionais contratados, dentre médicos, enfermeiros, odontólogos, auxiliares de enfermagem e agentes de saúde (Anexo 4).

A etapa inicial de dois anos de trabalho intenso propiciou um acúmulo de experiências, capacidade e infra-estrutura, que necessitam ainda ser amadurecidas, vivenciadas em novas perspectivas e refletidas. A despeito das especificidades de cada distrito, é preciso construir as bases comuns para a gestão do sub-sistema. (ATHIAS e MACHADO, 2001). Ainda não há consenso nacional entre os gestores dos distritos quanto ao manejo dos instrumentos de trabalho, planejamento e formas de avaliação inerentes ao SUS, como por exemplo, na parametrização de custeio e investimento per capita. Como estabelecer a eqüidade nos gastos? Por indivíduo? Base 
populacional? Acesso aos serviços? Relações sociais nas comunidades? (MINISTÉRIO DA SAÚDE 2001).

Os primeiros distritos implantados, o Distrito Sanitário do Leste de Roraima para a população Yanomami e o Distrito Sanitário Xingu, gerido pela UNIFESP, antiga Escola Paulista de Medicina, trouxeram alguns ensinamentos prévios sobre a sustentabilidade do modelo proposto, frutos de muitos anos de trabalho anterior: o controle social decorre da mobilização e acompanhamento das lideranças indígenas desde o início da implantação; o trabalho na área indígena deve enfocar problemas de saúde, com inserção e fortalecimento da equipe local, particularmente dos profissionais de nivel universitário na área, assessoria técnica permanente e a atuação reconhecida e profissional dos agentes indígenas de saúde no trabalho (USMA/UNIFESP 1999b, RODRIGUES E MENDONÇA 2000).

Neste intenso processo de mudança, parece que a participação dos profissionais de saúde indígenas e não indígenas é determinante para a organização e qualidade dos serviços oferecidos pelos DISEI. Do ponto de vista teórico-metodológico, interessa a esse estudo a composição das possibilidades do trabalho, da formação técno-política e a inserção institucional dos agentes indígenas de saúde enquanto elementos-chave e sujeitos profissionais dessa nova e complexa prática de saúde.

\subsection{Agentes Comunitários de Saúde e Agentes Indígenas de Saúde: caminhos e descaminhos da formação e institucionalização.}

"A única diferença que o agente comunitário tem da população geral de onde ele mora é que ele tem formação sobre saúde muito maior; mas enquanto cultura, enquanto costume, ele é uma pessoa igual ao próprio bairro, à própria comunidade; ele é o cara da comunidade onde mora, em que trabalha, dai também vem a importância de ele 
trabalhar onde mora, porque é uma pessoa que se identifica, que tem uma convivência enquanto característica da comunidade"

Tereza Ramos, liderança dos ACS em Pernambuco ix

A incorporação do Agente Comunitário de Saúde (ACS) ao sistema público de saúde tem-se mostrado polêmica. Trata-se de uma questão antiga, que em nosso meio vem ganhando novos contornos desde 1991, com a proposição do Programa de Agentes Comunitários de Saúde (PACS). As primeiras publicações sobre o trabalho de agentes de saúde remontam aos anos 60, com o emprego de agentes não profissionais ao processo de trabalho em saúde. Os feldshers soviéticos; médicos dos pés descalços na China; assistentes médicos dos Estados Unidos que faziam parte de programas sociais voltados à populações pobres urbanas e rurais, seguindo a orientação de uma política social responsiva e imediata às tensões surgidas com os movimentos dos direitos civis e conflitos sociais surgidos na época (MARTINS e col 1996).

Na América Latina a utilização de agentes de saúde em comunidades peri-urbanas e rurais expandiu-se nos últimos 20 anos, como estratégia da extensão de cobertura e universalização dos serviços de saúde. Desde 1975 o Programa de Preparação Estratégica de Pessoal de Saúde (PREPS), citado por SILVA, 1983, enfatizava a capacitação de agentes comunitários leigos, não pertencentes ao quadro institucional dos serviços de saúde. Para a autora, qualquer estratégia de extensão de cobertura dos serviços de saúde em países de terceiro mundo dependem do trabalho voluntário de pessoal não qualificado.

São inúmeros os Programas que vêm incorporando Agentes Comunitários de Saúde no processo de reformulação do sistema vigente, ou de composição de sistemas locais de saúde, visando obter melhorias da

\footnotetext{
ix In: A vinculação institucional de um trabalhador sui generis. O agente comunitário de saúde. Nogueira, RP e col. Rio de Janerio, IPEA, 2000.
} 
realidade sanitária. Além das iniciativas governamentais, existem trabalhos voluntários conduzidos por organizações não governamentais, como a Pastoral da Criança, ligada à igreja católica. Relatórios da instituição indicam o envolvimento de 65 mil agentes de saúde atuando no atendimento de crianças carentes em todo o país, prestando assistência a mais de 2 milhões de menores de 5 anos. Não faz parte dessa iniciativa a profissionalização dos agentes de saúde (MARTINS e col 1996, SOLLA 1996).

Outra experiência relevante, a do Estado do Ceará, envolveu mais de 4 mil agentes de saúde, vinculados aos governos estadual e de municípios de pequeno porte, cujo trabalho de visitação domiciliar e adoção de medidas simples, como cloração da água e uso da TRO- terapia de rehidratação oral foram capazes de reduzir significativamente os indicadores de mortalidade infantil (ANDRADE 1992).

Atualmente a atuação do ACS está vinculada ao Programa de Saúde da Família (PSF). Estima-se que $\mathbf{4 0 0}$ mil pessoas estejam envolvidas nestes programas, que estão reorientando as práticas de saúde pública, deslocando o eixo de assistência dos serviços de saúde para as comunidades. Este trabalho implantado inicialmente em cidades pequenas, de baixa densidade populacional e de escassos recursos de serviços e profissionais de saúde, paradoxalmente vem se tornando atraente e um diferencial de fortalecimento para o SUS nos municípios de grande porte pelo seu aspecto de incentivo e apoio financeiro de órgãos internacionais e do governo federal. Existem experiências bem sucedidas em municípios como Niterói, Belo Horizonte e Fortaleza (SILVA JA 2001).

Em São Paulo, o Programa de Saúde da Família foi desenvolvido a partir de 1996, em parceria com o Ministério da Saúde, Fundação Adib Jatene, Secretaria de Estado da Saúde e Hospital Santa Marcelina, sendo nomeado por Projeto Qualis (Qualidade Integral à Saúde). Até 1996 atendeu mais de 120.000 pessoas (CAPISTRANO FILHO 1997). As diretrizes do 
PSF/Qualis buscam integrar cura e prevenção, uma das maiores dicotomias da prática em saúde e valorizar a atuação do Agente de Saúde como um promotor da saúde e elo entre a equipe de saúde da família e a comunidade. Ainda que se destaque o componente educativo do trabalho do agente de saúde, sua lógica predominante é a extensão da oferta de serviços à população e o controle sanitário. Para SILVA JA (2001), os programas de agentes de saúde têm um grande potencial de mudança dos indicadores sociais e reversão dos perfis de morbi-mortalidade com medidas simples de caráter preventivo. Um dos aspectos mais dificultosos para operacionalização desses programas é a capacitação das equipes, no sentido técnico e também político.

É comum o uso do termo "sensibilização" em reuniões e treinamento de profissionais de nível superior na área, como se esses necessitassem de um convencimento especial para aderir à proposta, distanciada da formação tradicional em saúde. Muitas das experiências de treinamento estão centradas na composição de equipes de especialidades básicas da medicina (pediatria, ginecologia/obstetrícia e clínica geral). Outras valorizam modalidades de formação generalista, demandando cursos dispendiosos e de carga horária longa (SILVA JA 2001, Nogueira e col. 2000).

As discussões sobre a formação e o trabalho dos agentes comunitários não são conclusivas. Há concordância sobre o papel preponderante da supervisão de enfermeiros e médicos tanto na formação dos agentes comunitários, quanto para assegurar a continuidade e qualidade desses programas (MINAYO e col. 1990). Não há consenso sobre a inserção e/ou integração às instituições e serviços de saúde. A precariedade dos vínculos de trabalho reflete a situação de desvinculação e até de marginalidade que os agentes de saúde percebem frente ao sistema oficial de saúde. Uma alternativa seria a regulamentação da profissão de agente de saúde. No período entre 1993-2000, foram apresentados dez Projetos de Lei na Câmara 
Federal sobre a matéria, indicando sua relevância política e conflito (SILVA JA 2001).

Estudos internacionais refletem a mesma realidade. A avaliação do trabalho de 16 mil agentes de saúde na Tanzânia, África, (MAYOMBANA e col. 1990) evidenciou a necessidade de acompanhamento a longo prazo desses programas, e articulação ao sistema oficial de saúde pública, condições que esbarram em limitações de acesso e financiamento. Dentre as comunidades isoladas um estudo realizado por HUMMEL, citado por SIBTHORPE e BECKING (1998) avaliou uma experiência de formação e acompanhamento de assistentes médicos no Alaska e destacou a importância das políticas de contratação e remuneração adequadas como diferenciais de sucesso desses programas. Na Nova Zelândia, onde existem treinamentos para agentes de saúde aborígenes há mais de 100 anos, KRIECHBAUM (1993) constatou que o trabalho centrado na comunidade, os cuidados primários de saúde e as políticas de acesso à educação geral, salários dignos e emprego institucionalizado parecem garantidoras da efetividade dos programas de profissionalização para aborígenes.

No Brasil, SILVA, em 1983 estudou a realidade de trabalho de agentes de saúde rurais no Vale do Ribeira e propôs os seguintes indicadores necessários à avaliação do seu trabalho: a aceitação pela comunidade, custos, composição de um perfil profissional e a articulação da formação ao emprego formal.

Os estudos brasileiros sobre agentes de saúde ainda se restringem a descrição de experiências particulares abrangendo aspectos técnicos, culturais e políticos do trabalho. Não encontramos estudos de mensuração sobre impacto, epidemiológico à longo prazo, custos, profissionalização e empregabilidade que possam balizar políticas de formação e trabalho para esse segmento. 


\subsection{Especificidades da formação e trabalho dos Agentes Indígenas de Saúde.}

"Um dia eu estava caçando com meu tio. Aí encontrei no mato duas coisas de branco: um livro e uma garrafa. Eu nunca tinha conhecido essas coisas, então ele falou: escolhe. Eu escolhi o livro. Ele disse: sua escolha foi boa, então agora você vai estudar. A outra garrafa tinha bebida, tinha álcool. Eu guardei ela também. Então escolhi ser agente de saúde, eu quero estudar, e quero que você me ensine. Isso foi no ano 1996."

Tukupé Waurá, AIS da Aldeia Aruak, Xingu

Na América Latina a demanda pela formação de agentes indígenas de saúde por parte das comunidades indígenas vem se intensificando nos últimos dez anos, não só para garantir a atenção primária à saúde, mas também pela busca de novos elementos que favoreçam a comunicação entre a população indígena e os sistemas de saúde. Essa demanda do movimento indigenista, integrante dos movimentos sociais de minorias étnicas, é estratégica para a interlocução com as sociedades envolventes e evidenciase principalmente nas áreas de direito, educação e saúde.

A precariedade das condições de saúde de comunidades indígenas aliada à falta ou pouco preparo dos agentes de saúde é um fato constante referido em encontros sobre esta temática em relatórios técnicos e seminários (MENDONÇA 1996, FERRARI 1995).

Denominados inicialmente de monitores de saúde, o perfil dos indígenas que atuam na área parece ser bastante heterogêneo. Na Colômbia e Venezuela, é mais comum a atuação de mulheres nas áreas de saúde da criança e assistência ao parto (GUERREIRO e HERRERA, citado por MENDONÇA 1996). No Brasil, parece predominar o trabalho de indivíduos jovens do sexo masculino, que são interlocutores de suas comunidades para diversos assuntos.

O Sistema de Cadastramento de Agentes Indígenas de Saúde desenvolvido pela Coordenação de Saúde do Índio- COSAI/FNS (MINISTÉRIO 
DA SAÚDE; 1999e) dispõe de dados ainda parciais sobre o número, disposição e capacitação dos agentes. Estima-se por esta fonte a existência de 2000 agentes indígenas de saúde em atividade, sendo que mais de $70 \%$ deles trabalhando sem acompanhamento ou supervisão, $50 \%$ possuem escolaridade de primeiro grau incompleta, e $5 \%$ analfabetos.

Em algumas comunidades a atuação de indigenas está legitimada e decorreu de um longo processo interno de avaliação do trabalho do AIS que busca articular as terapêuticas tradicionais indígenas às do sistema de saúde ocidental. No cenário nacional, predomina o movimento de capacitação dos agentes de saúde realizado por diversas instituições não indígenas, externas à essa realidade e que difere bastante quanto aos seus objetivos, metodologia e formas de avaliação.

Um dos problemas mais graves apontados nas análises dos processos de formação é a insuficiência de acompanhamento prático após os módulos teóricos, e a inadequação dos conteúdos ao perfil epidemiológico das populações. Outro fator crítico é a não inserção do agente no sistema oficial de saúde. Na prática, sua formação é paralela à implantação de um subsistema de saúde indígena, já que inexistem mecanismos políticos que ordenem a formação e o trabalho dos AIS (USMA/UNIFESP 1996).

Dois centros formadores, vinculados a universidades, destacam-se neste processo: a Fundação Universidade do Amazonas, que trabalha com os povos indígenas do Rio Negro, propondo uma formação voltada à complementação de saberes e práticas relativas ao processo saúde doença (FIGUEROA, citada por MENDONÇA 1996), e a Escola Paulista de Medicina/UNIFESP que atua no Parque Indígena do Xingu desde 1965, desenvolvendo um programa de extensão universitária nas áreas de assistência à saúde, pesquisa aplicada e formação de recursos humanos. Os programas de capacitação do Xingu desde 1990 vêm dando prioridade ao preparo dos agentes de saúde para atuar como interlocutores técnicos e 
políticos de suas comunidades. A profissionalização em saúde e outras áreas vem se apresentando como uma estratégia política e pedagógica de formação em serviço, conferindo qualidade e organização da assistência à saúde no Parque (USMA/UNIFESP 1998a).

Os agentes indígenas de saúde do Xingu já foram objeto de alguns estudos, que buscaram compreender aspectos técnicos, políticos e antropológicos do seu trabalho (Anexo 5 e MENDONÇA 1996). Alguns dados preliminares revelam que a atuação dos agentes indígenas de saúde é relevante na detecção precoce e prevenção de doenças, e os AIS gozam de um poder diferenciado por lidar com a produção e reprodução do corpo humano, e com as representações sobre a vida e a morte de sua origem cultural. A concepção norteadora desses programas é a perspectiva de construção social da saúde no Xingu calcada no diálogo intercultural e na avaliação contínua do trabalho (USMA/UNIFESP 1998a).

No Xingu, a atuação dos agentes indígenas de saúde vem se modificando com a incorporação de alguns recursos tecnológicos e a compreensão do seu papel destacado nas ações de promoção da saúde e de organização do processo de trabalho no contexto do DISEI. O caminho que vem se delineando é o da profissionalização, uma reivindicação legítima que vem sendo respondida mediante um processo de profissionalização em serviço para 16 agentes de saúde como auxiliares de enfermagem indígenas, constituindo uma experiência inédita de formação profissional para os povos indígenas (Anexo 7). A partir de 1997, a capacitação de agentes de saúde foi mantida e diversificada para as áreas de saúde bucal, saneamento e microscopia. O desenvolvimento de recursos humanos para profissionais de nível superior veio ocorrendo nas modalidades de treinamento, capacitação e educação continuada.

Fazer parte de uma categoria profissional da área da saúde e pertencer às instituições prestadoras de serviços, trazem muitas expectativas 
e uma nova dimensão para o diálogo intercultural e autodeterminação dos povos indígenas (USMA/UNIFESP 1998).

A implantação dos DISEI em 1999 incrementou os processos de treinamento e tentativas de organização e normatização da formação dos agentes de saúde. Na Política Nacional de Atenção à Saúde dos Povos Indígenas a preparação de recursos humanos é destacada como:

"...instrumento fundamental de adequação das ações dos profissionais e serviços de saúde do SUS às especificidades da atenção à saúde dos povos indigenas e às novas realidades técnicas, legais, políticas e de organização dos serviços"(FUNASA 2000).

As instituições de ensino e pesquisa vêm sendo estimuladas para produzir conhecimentos e tecnologias que sejam adequadas ao interesse das comunidades, propondo programas especiais que facilitem a inserção do aluno indígena, com aulas de português, currículo diferenciado e vagas especiais.

De modo discutível, até certo ponto simplista, a formação do AIS vem sendo apresentada como uma estratégia que visa a apropriação de conhecimentos e recursos técnicos da medicina ocidental, de modo a somar ao acervo de terapias e práticas da medicina indígena (FUNASA 2000).

O programa de formação concebido no nivel central coloca-se como parte do processo de construção dos DISEI. No entanto, a agregação dos agentes indígenas de saúde como elemento-chave na construção desse processo não está clara. Pretende-se que o AIS desempenhem o papel de interlocutores de saúde nas aldeias, e resolvam $80 \%$ dos problemas de saúde nas aldeias, ficando $10 \%$ para a equipe multidisciplinar e $10 \%$ para o sistema de referências (CNS 2000).

"o indio que adoece deve procurar o AIS, que vai encaminha-lo ao posto de saúde da aldeia. Nas situações mais graves, um sistema de transporte, mantido em prontidão, levará o índio até o pólo-base" (COSTA 2000). 
Da interlocução cultural à capacidade técnica de intervir nas situações de emergência, passando pela vigilância à saúde, há um amplo leque de trabalho, requerendo responsabilidades, habilidades e competências que talvez não se encontrem nos processos de formação.

Paralelamente à implantação dos DISEIs, os cursos de capacitação de agentes de saúde foram ocorrendo em todo país. A FUNASA deu continuidade ao trabalho de um grupo de especialistas que elaborou uma matriz curricular de referência para os cursos, contendo cinco módulos de capacitação, em uma proposta de formação de 1000 horas de atividade. (Anexo 6). 0 processo procurou seguir os marcos preconizados pela Lei $n^{\circ}$ 9394/96, das Diretrizes do Ensino, no que diz respeito ao ensino básico, de caráter profissionalizante, visando facilitar o prosseguimento dos estudos nos niveis técnico e tecnológico. A FUNASA optou pela utilização de uma metodologia de ensino participativa, propícia à comunicação intercultural. (FUNASA 1999 e FUNASA 2000).

Em setembro de 2000, um encontro para avaliação do processo nas regiões norte, nordeste e centro-oeste, envolvendo cerca de 100 instrutores, elencou vários problemas de ordem institucional, cultural e pedagógica (FUNASA 2000).

Um embate presente desde 0 início refere-se ao papel normativo e centralizador da FUNASA na condução dos processos de formação. Por um lado, coloca-se o exercício do princípio pedagógico do trabalho. De outro, a centralização de um processo muito heterogêneo e que guarda especificidades regionais. Há ainda muitas insuficiências organizacionais e da esfera administrativa e política, que se refletem nos processos de formação. As críticas e problemas mais comuns citados no encontro foram: 
- "a proposta é muito intervencionista;

- cada distrito tem uma realidade que não está sendo considerada;

- as barreiras culturais dificultam o desenvolvimento dos cursos;

- a heterogeneidade dos AIS quanto as etnias, nível de escolaridade, experiência de trabalho;

- falta de supervisão e acompanhamento nos locais de trabalho;

- dificuldades dos técnicos e gerentes dos distritos em compreender e apoiar a metodologia de ensino;

- despreparo pedagógico e antropológico dos instrutores;

- dificuldades operacionais como: falta de pessoal em área, rotatividade de enfermeiros, insegurança dos auxiliares de enfermagem em relação ao agentes de saúde;

- atendimento no pólo-base e nas referências muito precário;

- dificuldades em compreender e interagir com as práticas de medicina tradicional;

- perfil inadequado de alguns AIS, selecionados mediante indicação das lideranças;

- perfil inadequado de alguns instrutores, que não reconhecem a dimensão pedagógica do trabalho e

- necessidade de legitimar e legalizar os cursos através de parcerias com as escolas técnicas de saúde". 
Um exemplo da heterogeneidade dos AIS encontra-se em Pernambuco.

Um levantamento dos cursos identificou 53 AIS, pertencentes a oito etnias, sendo um não alfabetizado, cinco com $1^{\circ}$ grau incompleto, quatro com $1^{\circ}$ grau completo, doze com o $2^{\circ}$ grau incompleto e $31 \mathrm{com}$ o $2^{\circ} \mathrm{grau}$ completo.

No médio Purus, AM, dos 40 agentes treinados, dois não eram alfabetizados e 38 possuíam o $1^{\circ}$ grau incompleto. Questões como o acesso aos cursos, participação das lideranças e dimensionamento do número de AIS para cada comunidade também devem ser considerados (FUNASA 2001).

A ausência de uma política efetiva de recursos humanos e a dinâmica e complexa condição de vida e trabalho dos agentes indígenas de saúde requer análise criteriosa. Está claro que a formação não deve apenas suprir uma carência de preparo técnico e viabilizar a inserção institucional de um grupo ocupacional; há que se pensar também na progressividade dessa formação no sentido de possibilitar a construção de trajetórias de profissionalização flexiveis, consoantes com as diretrizes atuais da legislação referente a educação profissional (MINISTÉRIO DA EDUCAÇÃO, 1999b).

Outro aspecto de fundamental importância são as mudanças sociais culturais e políticas que a profissionalização, o assalariamento e a institucionalização do trabalho podem trazer.

A complexidade do tema requer uma perspectiva de análise em diversos ângulos, que possibilite a compreensão do processo e dos papéis sociais que vêm sendo desenvolvidos.

Estamos partindo da premissa de que os AIS são sujeitos profissionais, inseridos em um contexto cultural diverso, produtores coletivos e não apenas consumidores individuais de conhecimento e que portanto, os 
processos de formação poderiam ser ordenadores e orientadores da organização da atenção à saúde indígena no âmbito do DISEI.

Este estudo pretende delimitar um campo de possibilidades para analisar esta temática, utilizando como cenário de referência a experiência de formação de agentes indígenas de saúde desenvolvida no Parque Indígena do Xingu, e os princípios conceituais do SUS, apreendendo seus aspectos dinâmicos de conflitos, perspectivas, e alternativas políticas. 


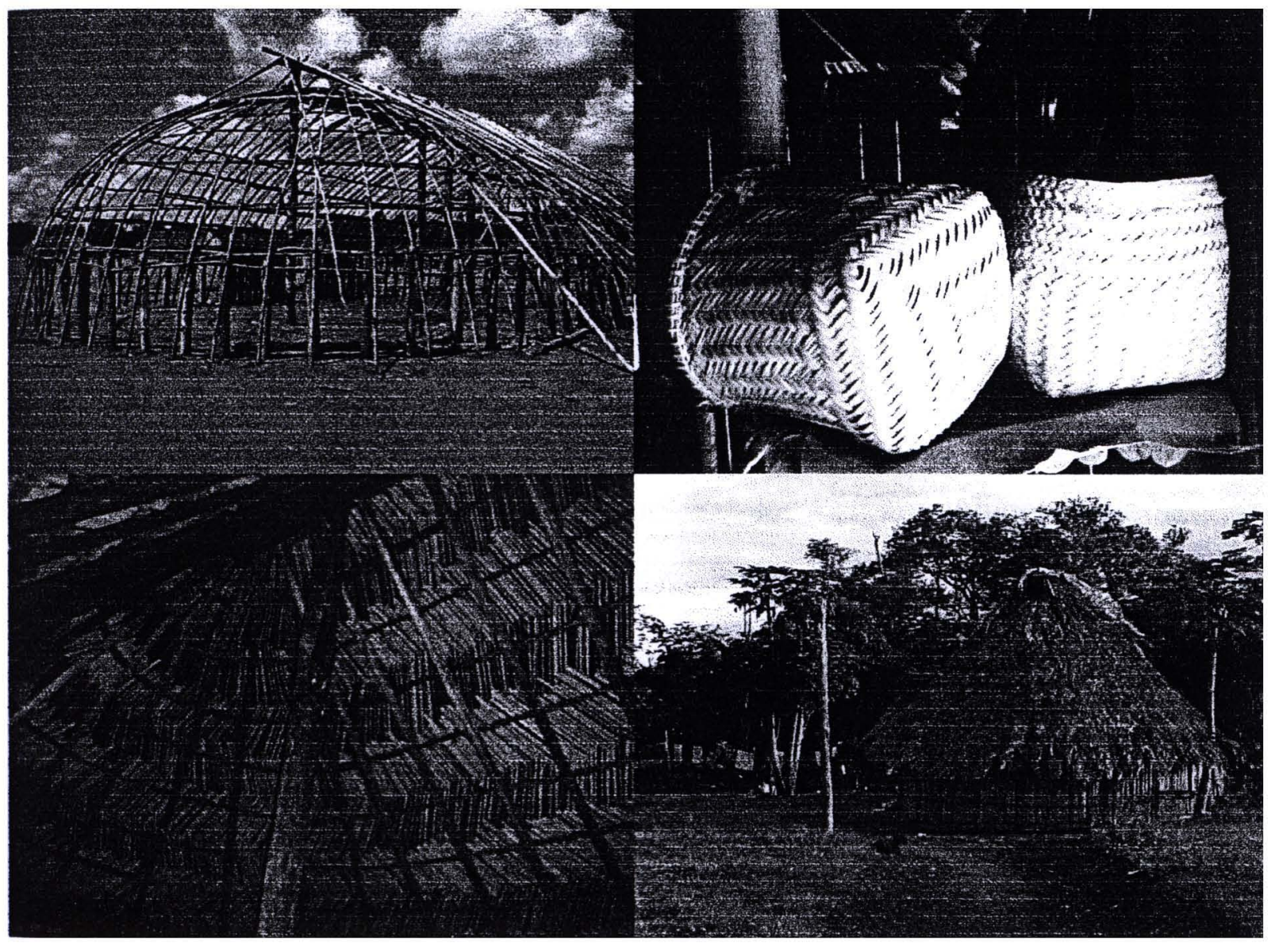




\section{ASPECTOS TEÓRICOS E METODOLÓGICOS}

\subsection{Objetivos do estudo}

\section{OBJETIVO GERAL}

Analisar a construção das políticas de formação dos agentes indígenas de saúde no Brasil tendo como referência a experiência de trabalho do Parque Indígena do Xingu e os princípios conceituais do Sistema Único de Saúde.

\section{OBJETIVOS ESPECÍFICOS}

- Obter um enfoque relacional entre a formação, trabalho, inserção profissional e inserção institucional dos agentes indígenas de saúde do Xingu.

- Compor o perfil profissional dos agentes indígenas de saúde e verificar sua adequação a programas de formação de agentes indígenas de saúde.

- Analisar a proposta dos Distritos Sanitários Especiais Indígenas enquanto um campo de aplicação da formação de recursos humanos para a saúde indígena.

\subsection{Percurso metodológico}

O objeto da pesquisa constituiu-se na busca do sentido das relações, conflitos e reflexões em torno do eixo da formação e inserção institucional de 
agentes indígenas de saúde a partir da implantação do SUS, no início dos anos 90 , configurando uma realidade complexa e abrangente.

Para compor um estudo com tantas possibilidades temáticas enfrentamos a necessidade de elaborar um desenho metodológico que permitisse integrar as questões norteadoras do estudo à diferentes dispositivos descritivos e analíticos.

Nos diversos campos da investigação científica há uma clara insatisfação com o paradigma dominante, o que vem justificando o uso de abordagens alternativas, evidenciando uma profunda crise epistemológica, teórica e metodológica (Khun 1975 cit por PAIM 2000).

Para SANTOS (2001) a crise da modernidade expressa no campo científico se configura na absorção do pilar da emancipação pelo da regulação, que incentiva a ciência a tornar-se uma força produtiva de mercado. Para ele expansão da capacidade de ação proporcionada pela ciência e tecnologia não se fez acompanhar de uma expansão semelhante da capacidade de previsão, e, porisso, a previsão das conseqüências da ação científica fica aquém da própria ação. A perda na confiança epistemológica leva a uma perplexidade diante da ambigüidade e complexidade do tempo presente. $\mathrm{O}$ autor considera que estamos vivendo uma transição da ciência e como no tempo de Rousseau devemos perguntar com simplicidade pelo papel de todo o conhecimento científico acumulado, se resultou no enriquecimento ou empobrecimento prático das nossas vidas. Citando Offe, sintetiza: "Tudo parece possivel na arte e na ciência, na religião e na moral, mas por outro lado nada parece viável para a sociedade como um todo" (SANTOS 2001, p: 57).

Dentre as diversas abordagens científicas alternativas MORIN coloca o paradigma da complexidade (MORIN 1990). 
Trata-se de uma aplicação generalizada da premissa de que a pesquisa científica deve respeitar a complexidade inerente aos processos concretos da natureza, da sociedade e da história. Talvez sua característica definidora seja a não linearidade da ciência no sentido da rejeição do simples causualismo e da possibilidade de pensar a realidade de modo não contínuo. Essa concepção faz avançar uma abordagem construtivista da ciência, que ocorre de modo institucionalmente organizado, no seio de uma cultura, dentro da linguagem. Os déficts da ciência apontados anteriormente vêm possibilitando a emergência desse novo paradigma, reconhecendo que na prática a ciência se realiza no contexto das instituições de produção socialmente organizadas, como em qualquer outro campo de prática social histórica.

Nesta perspectiva, pergunta-se: qual seria a ciência possível de ser pensada e produzida no Xingu?

SANTOS (2001), discutindo o papel metodológico das ciências sociais, toma como exemplo a interessante constituição do sujeito e do objeto na antropologia e nas ciências sociais a partir dos povos primitivos. A ciência moderna consagrou o homem enquanto sujeito epistêmico, mas expulsou-o enquanto sujeito empírico. Um conhecimento objetivo e rigoroso não poderia tolerar particularidades e percepções axiológicas. Foi nessa base que se construiu a dicotômica distinção entre sujeito e objeto. Na antropologia social, a distância era enorme. O sujeito era o antropólogo, o europeu civilizado, e o objeto era o povo primitivo ou selvagem. A distinção era tão grande que tinha que ser encurtada pelo uso de metodologias que obrigavam maior intimidade com o objeto, como o trabalho de campo etnográfico e a pesquisa participante.

Esta condição parece ter se modificado nos últimos anos, quando esses "objetos" passaram a ser concidadãos, membros de pleno direito da Organização das Nações Unidas. Subitamente, os "selvagens" passaram a 
estar no meio de nós, nas nossas sociedades, quando não somos nós próprios os selvagens (SANTOS 2001:p 83).

Uma possibilidade de exercício dos novos paradigmas seria a abertura entre as áreas de conhecimento (MINAYO 1994). Tal exercício alberga questões consideradas pertinentes à esse estudo, como a transdisciplinaridade, intersetorialidade e equidade, conceitos identificados com o processo de construção do SUS (SA 1993, PAIM 2000).

Na promoção de uma nova transdiciplinaridade é preciso separar e associar os niveis de emergência da realidade sem os reduzir às unidades elementares e às leis gerais. Para MORIN (1996) a verdadeira questão não está em fazer transdisciplinar, mas que transdisciplinar é preciso fazer. Trata de um saber que precisa ser refletido, meditado e discutido. Tenta resgatar a ciência que se faz partindo do sujeito, já que mesmo em nossas observações mais objetivas entra sempre um componente sujeito. Admite-se que o saber científico não se efetua por cumulação, mas por transformação. Na teoria complexa o sujeito conhecedor se transforma quando se inclui na formulação do objeto e do processo da pesquisa.

Todo conhecimento depende das condições, possibilidades e limites do nosso entendimento. Da possibilidade das ciências se comunicarem, produzindo novos e profundos saberes. Por isso, a teoria complexa articula a autoconstituição de conhecimentos sistêmicos (MORIN 1996).

A perspectiva primeira colocada para este estudo foi a de apreensão/compreensão da realidade de formação dos agentes indígenas de saúde partindo de duas premissas: esses são sujeitos sociais e profissionais originários de um contexto cultural diferenciado, participantes da construção de suas práticas de ensino e trabalho e produtores coletivos de mudanças institucionais em diferentes niveis; e de que o trabalho na área indígena é um lócus privilegiado de formação, porque interage dinamicamente com os aspectos culturais, sociais e políticos da realidade. 
Considerando a multiplicidade de dimensões presentes na situação problema, foi iniciada uma busca das manifestações da formação e do trabalho dos agentes indígenas de saúde que pudessem indicar os elementos teóricos necessários para análise.

FAZENDA e col. (1989) entendem que o referencial teórico de um pesquisador é o filtro pelo qual ele enxerga a realidade, sugerindo perguntas e indicando possibilidades, e que as decisões metodológicas devem decorrer do problema formulado.

Durante a realização da pesquisa, compreendeu-se que o no caso do Xingu,a trajetória histórica da UNIFESP como instituição formadora de agentes indígenas de saúde e os debates ocorridos nas instituições governamentais nos últimos dez anos que subsidiaram a formulação das políticas de educação e saúde indicavam a necessidade de privilegiar as ações e expressões dos agentes indígenas de saúde em diferentes estágios de formação e trabalho. Foram utilizadas complementarmente duas abordagens metodológicas: a observação participante, enquanto parte da vivência profissional da pesquisadora e a análise documental, compondo assim um campo de possibilidades de estudo. A experiência da UNIFESP no Parque Indígena do Xingu e os princípios conceituais e políticos do SUS colocaram-se como eixos orientadores da análise.

GIL (1994) considera que a pesquisa documental está indicada para a exploração de diferentes fontes documentais em grande número e diferentes origens, passiveis de tratamento analítico. A produção documental que versa sobre os processos de capacitação e trabalho dos agentes indígenas de saúde no Brasil é bastante extensa, em termos de relatórios técnicos e descritivos e encontros políticos, e rica em recomendações, mas são poucas as análises políticas e publicações científicas sobre o tema.

A década de 90 representou um período significativo de produção documental referente a construção das políticas públicas de saúde e da 
implantação de um sub-sistema de saúde indígena no SUS (MINISTÉRIO DA SAÚDE 2001c).

Observou-se que existem muitas manifestações desses sujeitos participantes do campo de análise expressas em documentos, relatórios, fotografias e filmes produzidos nos últimos anos no Brasil, esses últimos na maioria das vezes por indígenas. Para LAVILLE e DIONNE (1999) documentos sonoros e visuais, e não apenas escritos são portadores de informações. O pesquisador deve explora-los, tria-los, julgar sua validade em função das necessidades da pesquisa, critica-los ou categoriza-los, sendo essas últimas operações de análise. Os autores consideram que as fontes documentais se prestam à análise de conteúdo, que pode ser utilizada como instrumental de estudo nos embates políticos, de estratégias, ou ainda esclarecer fenômenos sociais particulares.

Podemos considerar que neste estudo foram trabalhados os seguintes dados: Como fonte primária - cadernos de campo da pesquisadora. Fontes secundárias: relatórios técnicos, relatórios de viagem de equipes de trabalho ao Xingu, documentos de legislação, fichas de avaliação, impressos utilizados no cotidiano dos agentes de saúde e filmes (Anexo 5 e 15).

A utilização de filmes e cadernos de viagem na constituição do objeto de pesquisa visou reconhecer narrativas e o pensamento indígena através de imagens e falas, atentando para suas manifestações imediatas (Anexo 17).

O amadurecimento das questões metodológicas transcorreu em ritmo condicionado pelas experiências de campo e pela percepção de seus resultados como a causa da escolha de tal ou qual perspectiva. Podemos admitir que nos estudos sobre sociedades e culturas o pesquisador faz um exercício de auto-conhecimento e reconhecimento de suas convicções e aspirações, não sendo estas nada mais do que sentimentos produzidos no meio social em que se vive e que, ao final, cumpre-se o papel de registrar 
escolhas, observações de seu tempo e de sua ordem de valores (ALMEIDA; 1997).

Compreendemos que o processo de profissionalização de índios na área da saúde propõe uma transformação social externa, no sentido de construção de cidadania para uma minoria étnica. Mas há importantes transformações no sentido interno do cotidiano indígena. Foram assim selecionadas as seguintes fontes documentais para o estudo:

- legislação sobre política indigenista de saúde e política de educação profissional de nível básico e técnico na década de 90;

- relatórios produzidos na USMA/UNIFESP na década de 90 sobre o trabalho de campo do Xingu, particularmente os processos de formação teórico-prática dos agentes indígenas de saúde;

- documentos oficiais e relatórios finais de conferências e seminários relativos à capacitação e inserção institucional de agentes indígenas de saúde produzidos no contexto do SUS;

- fitas de vídeo do acervo da UNIFESP produzidas em sua maioria por universidades, governo federal e ONGs indigenistas sobre o universo cultural indígena e cursos de formação de AIS.

O estudo sistematizou-se em três momentos:

$1^{\circ}$ exploratório

$2^{\circ}$ descritivo

$3^{\circ}$ analítico

No primeiro momento, procurou-se conhecer a vida e trabalho dos AIS em um plano mais geral no país. Nessa etapa, a pesquisa bibliográfica e os filmes foram de fundamental importância. Os filmes ajudaram a compor o 
cenário atual no qual o índio se insere, um exercício que corrobora o interesse crescente pelas imagens nos processos de produção e divulgação do conhecimento. O suporte imagético vem sendo usado na antropologia fílmica por FRANCE (2000), que destaca o homem apreendido pelo filme, na unidade e diversidade das maneiras como coloca suas ações, pensamento e meio ambiente. O filme vem sendo considerado a matéria essencial da tradição oral. A busca por esse tipo de documento, para LAVILLE, (1999) tem como peculiaridade a expressão de diferentes representações mentais: mitos, crenças, opiniões e sentimentos. Ressaltamos a autoria indígena em grande parte desses documentários e as possibilidades de análise educativa neles contida (Anexo 17).

No momento descritivo, foram selecionados relatórios, documentos e pareceres sobre o tema (Anexo 5). Os dados foram organizados de acordo com as categorias emergentes dos documentos.

Os relatórios foram examinados como fragmentos de experiências e continham o desafio de reconstrui-las e de reinterpreta-las, numa pretensa atitude de buscar significados e orientações em gestos de trabalho.

Os documentos escritos representaram a linguagem de uma política, na qual as contradições de informações constituíram-se em uma evidência significativa.

Buscou-se nessa etapa descritiva caracterizar o processo de trabalho no Xingu, o perfil pessoal e profissional dos AIS, o conteúdo e organização dos cursos.

As viagens de trabalho ao Xingu começaram a se estruturar de modo a permitir uma posição de escuta e aprendizagem. O cotidiano do trabalho passou a ser registrado em cadernos universitários, como uma espécie de diário, contendo conversas informais, impressões, pequenos acontecimentos, para ver o Xingu "de dentro". 
As escolhas e recortes que foram se sucedendo na descrição do objeto convergiram para o diálogo entre os temas de educação, antropologia e política. O esforço teórico de análise buscou ser de vigilância crítica frente a comunicação de documentos, textos e entrevistas (MINAYO 1994 p.203),

Este critério justifica no texto a descrição dos documentos e imagens entremeada por comentários, evidenciando um exercício de observação, diálogo e interpretação. As falas em destaque são ilustrativas, mas não podem ser consideradas como unidades temáticas de discurso dos sujeitos pesquisados.

A condução da pesquisa foi vivencial. No período de coleta de dados, entre 1999-2001, foram realizadas 15 viagens de trabalho ao Xingu, em periodos médios de 15 dias e 4 viagens a Brasilia, para participar de reuniões de um grupo de trabalho sobre formação dos AIS. Para FREITAS (2001), é no cotidiano vivencial que se ritualizam, problematizam, produzem e se legitimam as formas de viver e aprender. O cotidiano é um ponto de referência por excelência para o direcionamento das práticas de ensino e investigação, enquanto práticas sociais que buscam a melhoria da qualidade de vida.

A redação final do trabalho insere conceitos como "pistas" de análise e inclui pressupostos da educação histórico crítica, antropologia da saúde e política de saúde brasileira, sendo os resultados analisados em articulação com esses pressupostos. Procurou-se estabelecer um campo interdisciplinar de possibilidades, em seus aspectos dinâmicos de conflitos, alternativas políticas e perspectivas. 


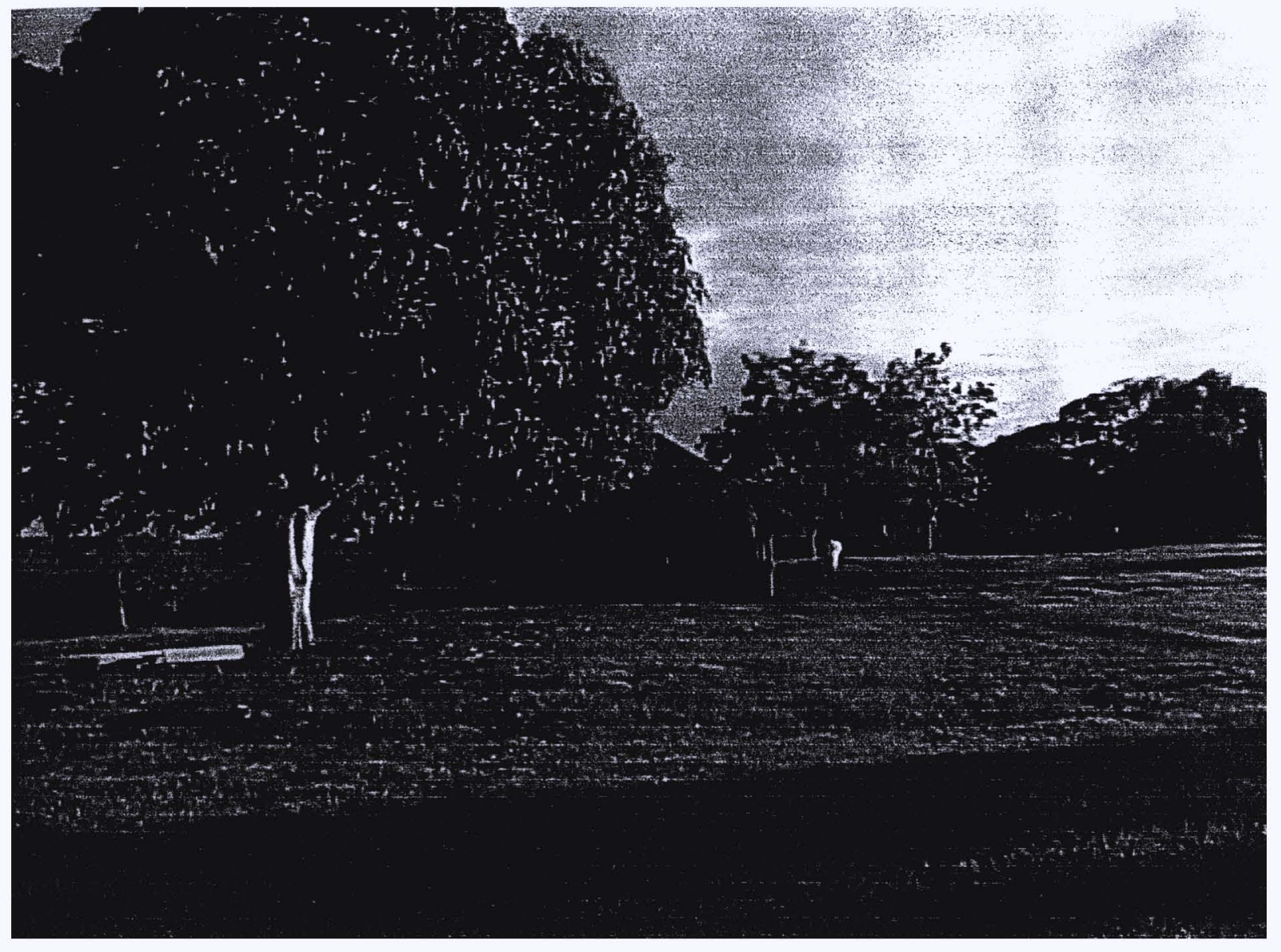




\subsection{Lugar e sujeitos do estudo}

\section{O Parque Indígena do Xingu}

O Parque Indígena do Xingu (PIX) foi criado pelo Governo Federal em 1961, em resposta ao intenso interesse surgido pelas terras do Brasil Central, situação que punha em risco a existência de tribos indígenas da região. Localiza-se ao norte do estado de Mato Grosso, e representa uma área de transição entre o cerrado e a floresta amazônica, com fauna e flora próprias desses dois ecossistemas, que se encontram praticamente intocadas. Nos anos recentes, a ocupação desordenada do entorno do parque pelos municípios, pesqueiros e fazendas vêm comprometendo severamente o meio ambiente com queimadas, extração de madeira, pesca ilegal e contaminação da água por mercúrio e agrotóxicos.

A superfície do parque é de 2.600 .00 hectares e ali são encontrados representantes dos quatro grupos lingüísticos do Brasil: Aruaque, Caribe, Jê e Tupi, além dos índios Trumai, compondo uma população de 3905 habitantes divididos em 14 etnias (BARUZZI 1989, USMA/UNIFESP 2000). Os grupos do parque, apesar de terem enfrentado processos de contato difíceis, preservam muito de suas caracteristicas culturais.

O trabalho de saúde está estruturado em três áreas de abrangência, referenciadas pelo curso do rio a saber: do Posto Indígena Leonardo, ao sul do parque; do Posto Indígena Pavuru, localizado na região central, e do Posto Indígena Diauarum, no norte da área (Anexo 2).

Em cada uma delas há um posto de saúde de referência que oferece cobertura assistencial às aldeias e suporte às equipes de trabalho.

Nos idos de 60, Orlando Villas Boas, quando administrava o parque, alfabetizou e treinou alguns jovens indios para ajuda-lo, nomeando-os como "secretários." Mas apenas no início dos anos 80, na administração de Olímpio 
Serra, que os índios começaram a trabalhar formalmente no parque, contratados pela FUNAI nas áreas de administração e apoio logístico, saúde e educação.

Em 1966, a Escola Paulista de Medicina traçou o primeiro esboço de um Programa de Saúde para o Xingu, propondo a implantação gradual de ações de saúde integradas, seqüenciadas, coordenadas e planejadas. Os índios que tinham começado a atuar no trabalho de saúde voluntariamente ou por indicação de suas famílias e vinham participando como intérpretes durante as visitas médicas, gradualmente foram aprendendo a manusear medicamentos e examinar doentes. A partir de 1983 começaram os treinamentos para monitores de saúde, que foram sendo ampliados quanto à abrangência de conteúdos e número de participantes (USMA/UNIFESP 1995).

A totalidade dos agentes indígenas de saúde que trabalham atualmente foi indicada pelas comunidades, têm fluência verbal e em alguns casos escrita na língua portuguesa e estão participando ativamente da construção do DISEI Xingu como membros da equipe multiprofissional.

\section{Sujeitos do estudo}

Na descrição do processo de formação em saúde do Xingu, optou-se por trabalhar com duas categorias de sujeitos: os sujeitos que ensinam e os sujeitos que aprendem, compreendendo que há uma relação dinâmica entre esses papéis, porque os conhecimentos a serem ensinados e aprendidos advém de realidades bastante distintas.

O universo de trabalho de saúde no Xingu é bastante amplo. Além dos profissionais tradicionais da área, como médicos, enfermeiros e odontólogos, no nivel universitário atuam ainda antropólogos, lingüistas e professores de português, matemática, ciências sociais e naturais, biólogos, agrônomos, arte 
- educadores entre outros. Esse crescente número de profissionais reflete a complexidade do trabalho e dos temas abordados nos cursos, e também o modo fragmentado pelo qual o conhecimento se organiza na cultura ocidental. Na quase totalidade, esses profissionais são provenientes de São Paulo e têm vinculação ou aproximação com universidades.

Dentre os profissionais de nivel médio predomina a atuação de auxiliares de enfermagem, que até o ano de 2001 eram exclusivamente não indígenas, oriundos de grandes centros ou das cidades do entorno do PIX. A interação desses no trabalho com os AIS é intensa e muitas vezes conflitante.

Os sujeitos que ensinam são também membros da comunidade, detentores de conhecimentos da medicina tradicional, como pajés, erveiros, raizeiros, lideranças indigenas e pessoas mais velhas.

Dentre os sujeitos que aprendem, foi dada prioridade nas manifestações de agentes indígenas de saúde e lideranças indígenas, com diferentes niveis de experiência, alguns dando continuidade ao processo de formação como auxiliares de enfermagem e conselheiros de saúde.

As falas foram extraídas de fontes documentais, como relatórios e também dos diários de viagem. Compreendeu-se que ainda de maneira indireta, esses documentos puderam dar voz a esses sujeitos.

\subsection{Aspectos éticos}

"Ética é um segredo do trabalho, que ajuda a fazer o trabalho melhor. É como a senha do banco: só pode contar para quem é muito de perto".

Yanahim Waurá, auxiliar de enfermagem indigena, 2000. 
A vivência adquirida em anos de trabalho na área de formação de recursos humanos, serviços de saúde pública e mais recentemente em comunidades indígenas motivou-me a buscar, no curso de pós graduação, conhecimentos sobre os aspectos éticos que permeiam as relações de trabalho, já que as equipes multiprofissionais são heterogêneas, com várias hierarquias sociais e que se interelacionam com usuários de diferentes ambientes sócio-culturais. Em se tratando-se de grupos sócio-culturais minoritários, o conflito é mais evidente (OLIVEIRA 1998).

O Conselho Nacional de Saúde, do Ministério da Saúde, mediante a Resolução no 196, de 10 de outubro de 1996 regulamentou pesquisas envolvendo seres humanos. Seus aspectos éticos são norteados pelos princípios da autonomia, não maleficência e justiça. A resolução 394/00 que orienta a pesquisa em comunidades indígenas. Segue esses mesmos princípios (CNS 2000).

O trabalho em questão não envolveu riscos, e utilizou prioritariamente dados secundários como fonte de informação. Minha atitude como pesquisadora e profissional de saúde nas visitas realizadas ao Parque Indígena do Xingu foi de "escuta" e aprendizagem. 


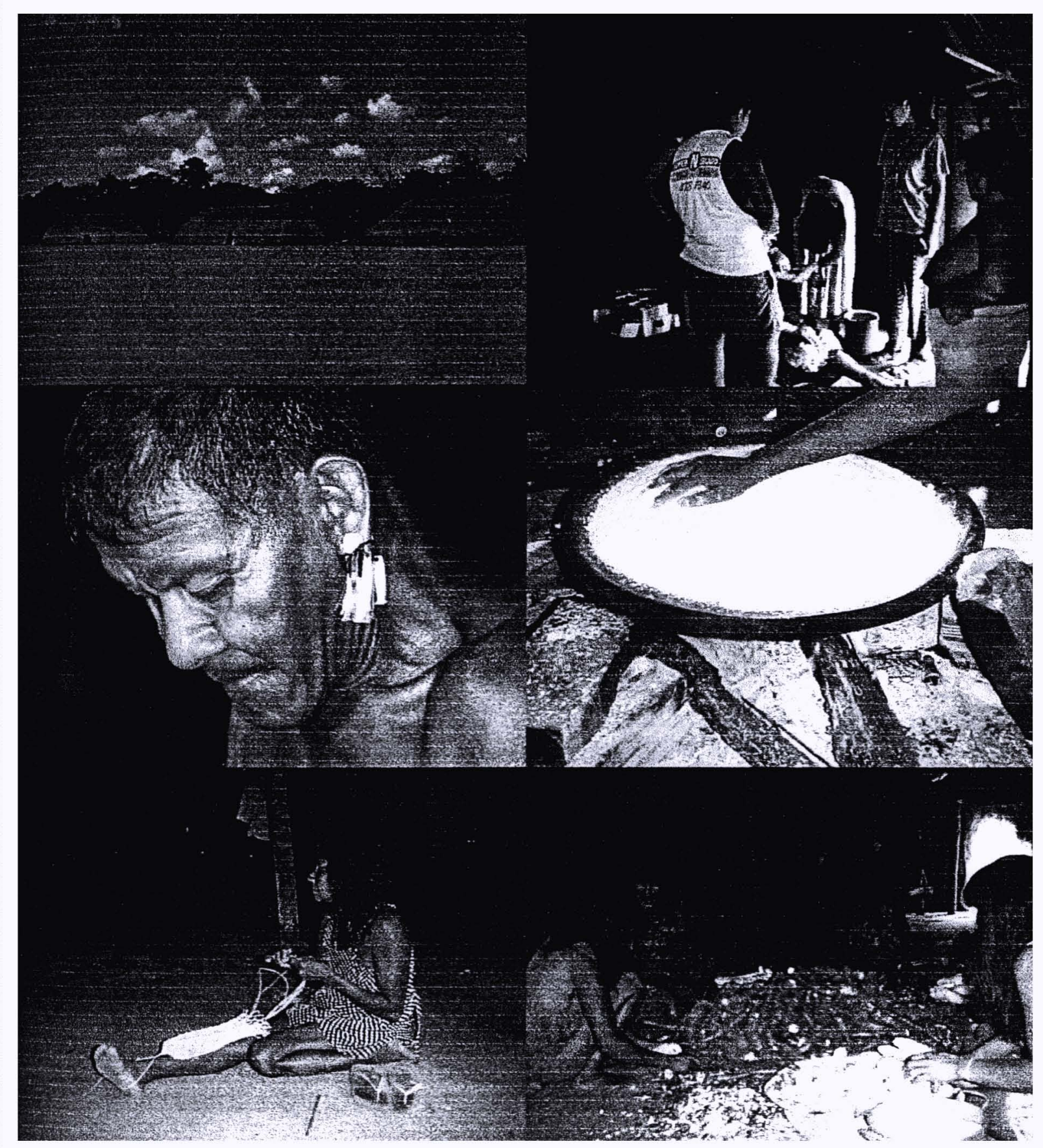




\section{DESCRIÇÕES}

3.1 A formação de agentes indígenas de saúde na década de 90.

O início de uma discussão sistematizada sobre o perfil profissional e preparo dos agentes indígenas de saúde ocorreu na II Conferência Nacional de Saúde Indígena (MINISTÉRIO DA SAÚDE 1993). O relatório final apontou os seguintes princípios e diretrizes para a capacitação dos AIS:

- reconhecimento e regulamentação dos AIS como categoria profissional;

- participação decisiva das comunidades nos processos de seleção;

- capacitação técnica com enfoque nas ações de promoção da saúde;

- conteúdos da formação de acordo com o perfil epidemiológico, organização sócio-cultural e medicina tradicional de cada povo e;

- formação específica para agentes de saúde bucal.

Nos anos de 1995 e 1996 várias reuniões e oficinas de trabalho realizadas em todo o pais debateram o tema. As denúncias de precariedade das condições de saúde das comunidades indígenas aliada à falta ou pouco preparo dos agentes de saúde foram constantes nos relatórios técnicos desses encontros (FERRARI 1995, MENDONÇA 1996, FUNASA 2000).

As avaliações identificavam ainda preconceitos por parte da estrutura pública de saúde, diferenças sócio-culturais significativas e infra-estrutura deficitária, mas consideravam o impacto epidemiológico do trabalho dos 
agentes e a possibilidade de constituir uma formação diferenciada do ponto de vista histórico e cultural (INESC 1998).

Paralelamente, o movimento indigenista na América Latina veio se construindo como movimento social de minorias étnicas (TORRES e RIO 2001), produzindo possibilidades de aumento do capital social e visibilidade política necessária para a reconstrução cultural desses povos, formando a base de uma consciência contestatória que se opõe a ideologia da democracia racial. Esses movimentos vêm dando prioridade às questões de saúde, com diferentes enfoques sociais, profissionais e institucionais. A formação de agentes indígenas de saúde intensificou-se, ainda de forma assistemática, para garantir a atenção primária à saúde nas aldeias e a de busca de novos elementos facilitadores da comunicação entre as comunidades indígenas e os sistemas de saúde.

Com o esvaziamento da atuação da FUNAI na década de 90, profissionais de saúde, associações indígenas e entidades não governamentais passaram a assumir papéis de interlocução institucional e mediação cultural e ainda a condução das demandas dos povos indígenas, fortalecendo o indigenismo como movimento social (LANGDON 2000).

A implantação dos Distritos Sanitários Especiais Indígenas em 1999 parece ter deslocado fortemente esse movimento para a área da saúde, uma situação merecedora de estudos aprofundados (ATHIAS E MACHADO 2001).

No Brasil os AIS estão sendo valorizados como interlocutores de saúde nas aldeias, e sua formação direcionada a capacita-lo para aproximar o índio doente do atendimento do sistema de saúde (MINISTÉRIO DA SAÚDE 1999e, CNS 2000).

Destacam-se nos anos 90 dois estados da federação: Mato Grosso e Amazonas, que já mantinham serviços de saúde para populações indígenas, ainda que de maneira precária, experiências de contratação de AIS pelas 
prefeituras e demais órgãos públicos que desencadearam investimentos na sua capacitação, configurando uma nova necessidade: da profissionalização, enquanto sujeitos que legitimamente aspiravam seu reconhecimento e inserção no sistema oficial de saúde não apenas como multiplicadores de ações educativas, mas profissionais capazes de intervir e modificar a realidade de saúde de suas comunidades.

No Mato Grosso o processo de profissionalização avançou conduzido pela Escola Técnica de Saúde do SUS $^{x}$ com a criação de um curso de formação para auxiliares de enfermagem indígenas, nos moldes de uma experiência pedagógica e foi assegurado o atendimento da escolaridade em nível fundamental para a clientela.

A primeira turma de 116 auxiliares de enfermagem indígenas concluiu o curso em junho de 2001. Este grupo de profissionais passou a integrar as equipes dos distritos sanitários especiais indígenas do Mato Grosso, tornando-se uma referência, mas não única possibilidade de composição de um trajeto profissional para os agentes indígenas de saúde em todo o país. (Anexo 7).

O Ministério da Saúde estimava em 1999 atrás a existência de 4 mil AIS trabalhando no pais (FNS, 1999). Em setembro de 2000, um censo realizado pela FUNASA identificou 2311 agentes de saúde em atividade, sendo 1545 contratados pelos Distritos Sanitários Especiais Indígenas. Os números são flutuantes, pois há um contingente significativo de pessoas que atuam descontinuadamente nas comunidades e outros que ainda não possuem contrato de trabalho por dificuldades de acesso à documentação.

A figura do agente indígena de saúde vem se destacando enquanto sujeito de um novo processo de trabalho, constituido a partir da implantação

\footnotetext{
${ }^{x}$ O processo 159/98 do Conselho Estadual de Educação/MT autorizou o funcionamento de um curso de auxiliar de enfermagem para povos indigenas. A estrutura curricular foi organizada em 800 horas de teoria e 640 h de prática, totalizando 1440 horas, distribuidas em 4 módulos (Anexo 7 ).
} 
dos DISEI. Até 2002, está prevista a capacitação e contratação de 2.644 profissionais pela FUNASA, abrangendo novas áreas de conhecimento como saneamento, microscopia e saúde bucal. O objetivo da Fundação é ampliar o espectro de resolução dos problemas locais de saúde nas comunidades. (CNS 2000).

Os processos de capacitação vêm sendo realizados por diversas instituições e diferem bastante quanto aos seus objetivos, metodologia e formas de avaliação.

Na III Conferência Nacional de Saúde Indígena realizada em maio de 2001, a formação e institucionalização de agentes de saúde foi debatida na perspectiva da consolidação da inserção dos profissionais indígenas nos Distritos Sanitários Especiais Indígenas, em concordância com os princípios do Sistema Único de Saúde e as bases legais do Sistema de Nacional de Ensino, fortalecendo as convergências entre a educação indígena e educação profissional (LDBE/96 e Parecer CNE 4/99). Foram discutidas nesse fórum as perspectivas de articulação intersetorial e interinstitucional das esferas públicas municipal, estadual e federal para a execução de novas ações de saúde e estabelecimento de novos espaços de trabalho.

Destacamos os seguintes aspectos recomendados no Relatório Final (MINISTÉRIO DA SAÚDE; 2001c):

- "vinculação empregatícia" dos agentes de saúde aos Programas de Saúde da Família e/ou redes de saúde dos municípios abrangidos pelos Distritos as diferentes realidades culturais envolvidas;

- fortalecimento de parcerias com instituições formadoras da rede de ensino técnico e participação em projetos governamentais de formação em saúde, como o PROFAE (Projeto de Profissionalização de Trabalhadores da Área de Enfermagem/ MS); 
- possibilidades de formação e inserção profissional de agentes indígenas em nas áreas de saneamento, microscopia e saúde bucal;

- incorporação de conhecimentos e de profissionais da medicina tradicional indígena ao espaço de trabalho dos DISEIs, como parteiras, raizeiros e pajés".

Comparando-se os relatórios das conferências de 1993 e 2001, constata-se que nesse período houve avanços políticos e pedagógicos no processo de formação, tentativas de sistematização curricular pelos órgãos competentes e maiores possibilidades de articulação entre diferentes instâncias de ensino e serviço. As demandas para formação de AIS estão mais claras, e seu espaço de trabalho mais definido. Há um esboço ainda tímido de mecanismos ordenadores da formação e institucionalização do trabalho dos AIS. 


\subsection{Descrição do perfil de trabalho dos agentes indígenas de saúde em diferentes contextos: Amazonas, Colômbia e Venezuela.}

As experiências relatadas a seguir demonstram parte do movimento que vem se organizando em torno da profissionalização do trabalho em saúde para os índios nas duas últimas décadas, os avanços históricos e ampliação das concepções de direito ao trabalho e do reconhecimento de órgãos internacionais sobre a autenticidade cultural e autodeterminação dos povos indigenas e tribais (UNESCO 1997, LANGDON 2000). Pretende-se que essas descrições possam subsidiar a análise do perfil de trabalho dos AIS no Xingu.

\section{Experiência do Amazonas - FOIRN - Federação das Organizações Indígenas do Rio Negro.}

Um exemplo da participação indígena no processo de formação de agentes de saúde ocorre na Amazônia, através da FOIRN, que agrega 28 entidades. O acúmulo de 20 anos na luta pela educação, saúde e demarcação de terras capacitou o movimento para expressar suas demandas quanto ao modelo assistencial e suas concepções de saúde. Há cerca de 200 agentes de saúde atuando na região, em sua maioria lideranças indígenas. $\mathrm{Na}$ avaliação dos índios falta integrar ao processo de formação e institucionalização as práticas de medicina tradicional e sua principal reivindicação é a inclusão do trabalho dos pajés. Outro aspecto relatado pelos AIS é a carência de instrumental educativo e metodológico específico para a formação em saúde, uma vez que a maioria domina a língua portuguesa e concluiu os estudos de educação fundamental (SSL 1998).

Em 1999 os cursos passaram a ser integrados com o PACS - Programa de Agentes Comunitários de Saúde e os AIS incentivados a integrar uma associação profissional, a AAISARN- Associação de Agentes Indígenas de 
Saúde do Rio Negro a fim de fortalecer o movimento de reconhecimento profissional como uma categoria profissional diferenciada.

São os seguintes requisitos estabelecidos na Federação quanto ao perfil de contratação de agentes de saúde:

- $\quad$ ser indicado pela comunidade;

- $\quad$ residir na área de atuação;

- $\quad$ pertencer à sociedade em que vai atuar;

- não ter outro vínculo empregatício;

- ter um bom relacionamento com a comunidade e ser alfabetizado em português;

- ter idade mínima de 20 anos e

- manifestar interesse, aptidão e responsabilidade para o trabalho em saúde.

Em 1998, uma oficina de trabalho avaliou o processo de mais de 10 anos de formação, e propôs um currículo único, organizado em três áreas: de ação política, pedagógica e técnica (AAISARN 1998).

\section{A experiência colombiana}

A sociedade colombiana encontra-se em um processo intenso de conflitos, violência e mudanças. Os documentos referentes ao trabalho de saúde para as comunidades indígenas têm um caráter eminentemente político e indicam o acesso à informação e os processos de capacitação de 
agentes de saúde como elementos estratégicos para a autonomia indígena e desenvolvimento auto-sustentado da região (HERRERA e LOBO 1998). Os estudos locais salientam ainda que as parcerias com o poder público são fundamentais para legitimar esses processos e garantir sua continuidade. Os chamados promotores de saúde rural indígena estão sendo formados desde 1985, com uma proposta educativa de forte cunho antropológico. (ETNOLLANO 1995). É enfatizada igualmente a formação antropológica dos profissionais de nivel universitário, as relações entre cultura, ambiente e sociedade e as metodologias participativas de ensino. Os documentos que descrevem as dificuldades dos processos destacam as permanentes contradições conceituais entre a antropologia e as disciplinas de saúde e a racionalidade dos programas e agentes financiadores que exigem resultados imediatos em termos da relação custo/esforço e benefício.

O conteúdo técnico dos cursos enfatiza ações de vigilância à saúde, como o controle do crescimento infantil e a avaliação do estado nutricional da população.

A experiência indicou que o perfil dos agentes pode ser conduzido para duas instâncias: institucional e comunitária.

Perfil do promotor de saúde institucional

1. Diagnostica as enfermidades comuns e presta primeiros socorros;

2. Repete os discursos memorizados sem maiores impactos na comunidade;

3. Facilita o trabalho médico na comunidade;

4. Espera que os problemas ocorram para buscar soluções e;

5. Seu trabalho está centrado no Posto de Saúde. 
Perfil do promotor de saúde comunitário

1. Investiga a realidade de sua aldeia;

2. É crítico e ativo diante dos fatores de risco que afetam sua população;

3. Educa orientando sua comunidade e aprende dela;

4. Compartilha as atividades sociais, econômicas e políticos culturais de sua população e

5. É um bom técnico sanitário, sabedor dos primeiros cuidados aos enfermos.

\section{O promotor de saúde na Venezuela}

A população indígena da Venezuela se concentra na região Amazônica. As dificuldades de acesso aos serviços de saúde e a baixa efetividade dos programas de saúde colocaram a figura do médico como principal protagonista do trabalho em saúde e muito distante das populações mestiças e indígenas. (VENEZUELA, s/d) A formação de agentes de saúde é considerada como uma prioridade política de democratização do conhecimento em saúde e organização das comunidades na perspectiva da valorização cultural e desenvolvimento auto-sustentado.

Nos cursos, salientam-se o enfoque processual da aprendizagem e a preocupação em recuperar práticas da medicina tradicional e do modo de vida dos antigos praticantes da medicina indígena em ações denominadas de restituidoras da saúde. $\mathrm{O}$ trabalho dos monitores de saúde sistematiza-se nas seguintes fases: 
Fase 1: Sensibilização da comunidade;

Fase 2: Capacitação dos promotores, na prevenção de doenças;

Fase 3: Auto gestão em saúde - desenvolvimento de ações de prevenção e restituição da saúde, nas quais se envolvem todos os habitantes da comunidade.

O promotor dá os primeiros cuidados e participa ativamente da organização social comunidade. Seu espaço de atuação é a prestação da assistência à saúde em nível básico, desenvolvendo prioritariamente ações de vigilância à saúde, prevenção e controle de doenças por meio de visitas domiciliares, atividades educativas e assistência primária, sempre supervisionados por profissionais de saúde capacitados para a função.

Esses diferentes contextos espelham a complexidade e diversidade da realidade da formação de agentes de saúde no continente, mais especificamente na Amazônia, realidade que guarda relação com a dinâmica de vida e trabalho de formação dos AIS do Xingu.

\subsection{Vida, trabalho e saúde no Xingu:}

\subsubsection{Um pouco de história}

O Projeto Xingu vem sendo desenvolvido pela UNIFESP como um programa de extensão universitária desde 1965. Ao longo dos anos o trabalho veio se modificando, buscando responder às novas e crescentes demandas sanitárias conseqüentes à experiência de contato dos povos xinguanos com a sociedade nacional. As necessidades de assistência à saúde das comunidades partiram de experiências anteriores com os povos indígenas do Araguaia e além da atenção médica individual abrangeram campanhas de vacinação e inquéritos epidemiológicos, realizadas por 
professores, profissionais e grupos de alunos de medicina e enfermagem. Essas ações eram complementares ao trabalho médico da FUNAI existente no parque. A sistematização da atenção médica pela UNIFESP possibilitou a identificação de diversos agravos e organização de algumas referências de serviços hospitalares nos grandes centros como Brasilia e São Paulo, um trabalho de apoio à assistência prestada pela FUNAI O programa de saúde no Xingu caracterizou-se por duas raras condições em se tratando de áreas indígenas: a continuidade e o planejamento, além do monitoramento científico de professores da Universidade.

Um grande número de docentes, residentes e alunos da Escola Paulista de Medicina passaram pelo Xingu. Nos primeiros 10 anos, 0 transporte era facilitado por aeronaves de grande porte da Força Aérea Brasileira, o que possibilitou a participação de mais de 400 pessoas no Projeto, uma experiência tão determinante em suas vidas que formou uma "tribo" em São Paulo: o grupo xinguano, coordenado desde o início pelo Prof. Dr. Roberto Baruzzi. Para ele, uma das explicações para a continuidade do programa por quase quatro décadas é a participação dos alunos, muitos dos quais voltam a colaborar como residentes, profissionais e docentes (BARUZZI 2001).

Desde os primeiros anos de atividades, os médicos eram acompanhados por jovens índios atentos que participavam das viagens dos profissionais, preparavam os locais de exames, ajudavam nas traduções e davam medicamentos. Essa presença minimizava as já mencionadas dificuldades para manutenção da assistência contínua nos postos indígenas, tanto de pessoal médico como para-médico.

Desde 1984 os indios vêm sendo treinados na área da saúde, como monitores de saúde no Posto Indígena Diauarum, uma iniciativa da enfermeira Estela Würker. Alguns por interesse próprio ou convite de profissionais realizaram treinamentos nas cidades sobre injeções, 
microscopia de malária e primeiros socorros. Aos poucos, um grupo de trabalho de indígenas na área da saúde se constituiu no parque. A formação dos AIS despontou como um caminho natural para avançar a organização dos serviços locais de saúde no PIX, garantindo a assistência mínima nos períodos de ausência de profissionais (USMA/UNIFESP 1996).

Além de ampliar a cobertura de atendimento à saúde, o trabalho dos agentes contribuía para a compreensão das práticas da medicina ocidental exercida pela UNIFESP e desencadeava ações de educação e promoção da saúde. A discussão que se fazia desde o início da formação sobre o perfil dos monitores apontava claramente seu papel de vigilante do estado de saúde da comunidade. O monitor de saúde deveria ser um membro da comunidade, pelos quesitos de linguagem, residência e convívio e também dominar 0 português. Em seu preparo deveriam atuar profissionais de antropologia, e não apenas de saúde.

A lenta composição desse perfil para os AIS evidencia duas dinâmicas: a primeira, de transformação social externa, no sentido de construção da cidadania profissional para uma minoria étnica, e a segunda, interna, no sentido das mudanças que esse trabalho operou no cotidiano indígena. Essa dinâmica será aprofundada posteriormente.

Até 1990 a preparação dos AIS ocorreu de forma assistemática. Era grande o número de alunos interessados, não apenas no trabalho, mas na oportunidade de viajar, aprender português e conhecer a gente de fora, os caraibas.

"Eu fiz um curso no Rio de Janeiro. Rapaz, não entendia nada, não sabia falar nem responder, mas fiquei lá, escutando, e fui gostando de trabalhar, continuei no trabalho já tem 20 anos que eu estou na saúde"

Moiawê Kaiabi, auxiliar de enfermagem indígena, 2000. 
Normalmente a indicação de alunos para o curso era feita pelos profissionais da Universidade e lideranças das comunidades. No período de 1990-97 foi desenvolvido um programa de capacitação para os monitores, já então denominados de agentes de saúde, coordenado pela Dra. Sofia Mendonça. Realizados regularmente no mês de julho, os cursos atraiam um grande número de AIS e um expressivo grupo de profissionais e alunos da UNIFESP.

Com o passar dos anos, o número de profissionais mobilizado para os cursos aumentou e se diferenciou, refletindo uma melhoria de qualidade conceitual e metodológica, e busca da profissionalização, com a participação crescente de especialistas de diversas áreas, e não apenas médicos.

Além de propiciar aos alunos e professores da universidade a experiência de contato com a saúde de populações indígenas, a coordenação do Projeto, que a partir de 1996 passou a ser do Dr. Douglas Rodrigues, adotou a estratégia de capacitação de indígenas para outras dimensões do trabalho em saúde, passando a delinear ações tecno-políticas de inclusão da temática de saúde indígena no sistema público de saúde, com expressiva participação dos agentes de saúde nos processos de articulação interinstitucional e na gestão da saúde do parque (USMA/UNIFESP 1998a).

Partiu-se do entendimento de que a capacitação de indígenas para o trabalho seria o eixo estruturante de um sub-sistema diferenciado de atenção básica à saúde dos povos indígenas articulado ao SUS (USMA/UNIFESP 1998b).

A partir de 1994, a composição de parcerias, com destaque à ATIXAssociação Terra Indígena Xingu, criada com uma proposta de atuação interlocal para a defesa da terra, revitalização cultural, educação, saúde e comercialização de produtos indígenas (ISA 2001) e a participação efetiva de lideranças indigenas no processo de organização da atenção à saúde no 
Xingu esboçaram o embrião do Distrito Sanitário Especial Indígena do Xingu (USMA/UNIFESP 1998b).

O conteúdo dos cursos passou a abordar organizadamente elementos da política de saúde, e sentiu-se a necessidade de capacitar os profissionais de nível universitário para uma abordagem pedagógica mais efetiva. Em 1997 foi realizado um curso de capacitação pedagógica para profissionais de saúde indígena em parceria com a Faculdade de Saúde Pública da USP, aprofundando a competência educativa de um grupo de 22 profissionais que já possuía ampla experiência técnica em saúde indígena, preparando as bases do curso de formação de auxiliares de enfermagem indígenas (FSP/USP 1997).

A crescente complexidade do processo está refletida no gráfico 1, demonstrativo dos profissionais envolvidos nos cursos ao longo dos anos. 
Gráfico 1. Participação dos profissionais por categoria nos cursos de formação, Xingu, 1995 a 2001.

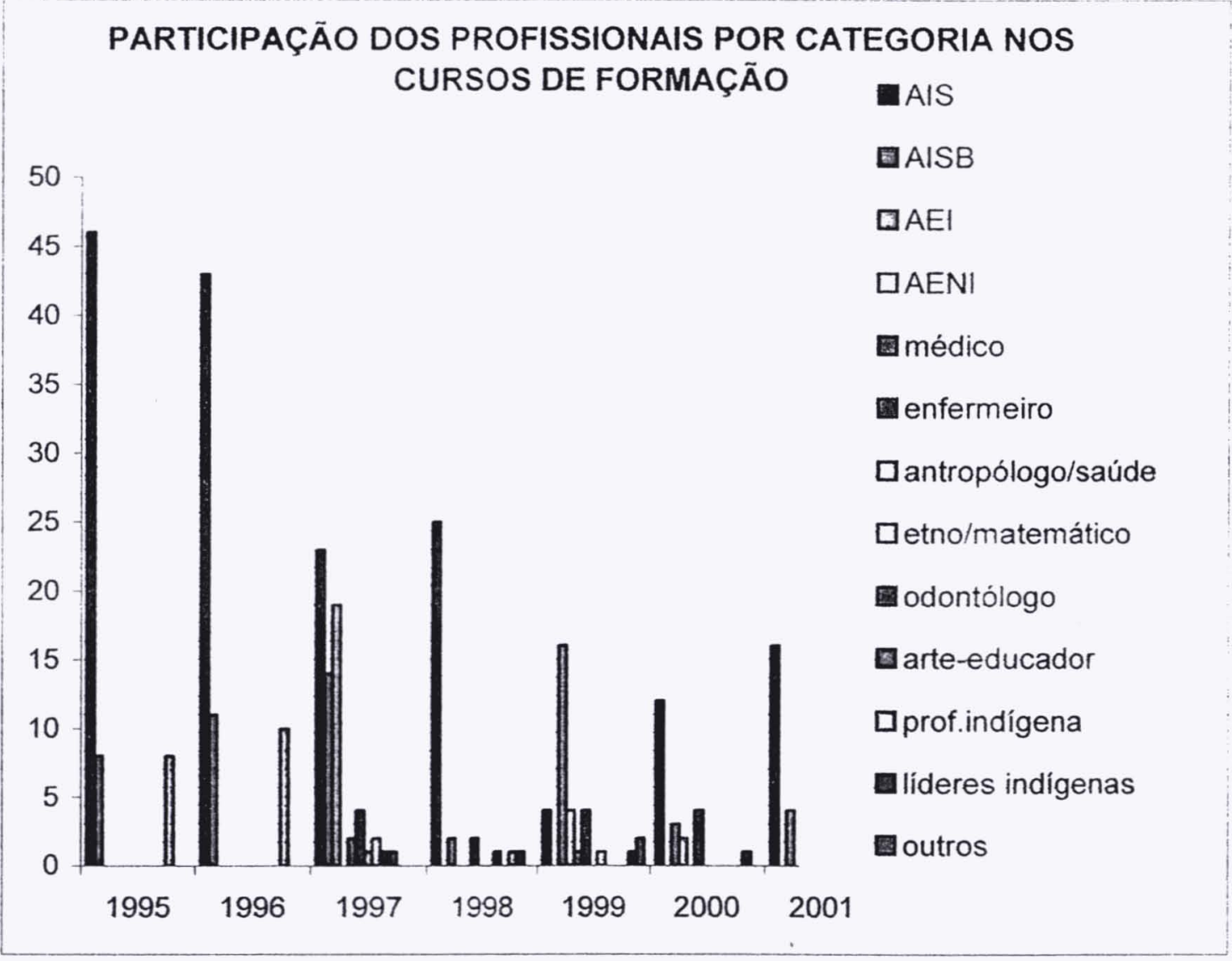

Os agentes indígenas de saúde do Xingu já foram objetos de alguns estudos, que buscaram compreender aspectos técnicos, políticos e antropológicos do seu trabalho (USMA/UNIFESP 1999, Mendonça 1996). Tais estudos demonstraram que a atuação dos agentes indígenas de saúde no Xingu é relevante na detecção precoce e prevenção de doenças, e que os AIS gozam de um poder diferenciado por lidar com a produção e reprodução do corpo humano, com as representações sobre a vida e morte de sua origem cultural. Existe a concepção de que os programas de formação desenvolvidos pela UNIFESP fazem parte de uma construção social, sendo o diálogo intercultural, a integralidade e a avaliação contínua os princípios norteadores do trabalho (USMA/UNIFESP 1999b). 
A partir de 1999, a presença mais constante de profissionais de saúde na área indígena proporcionou um salto de qualidade ao processo de formação. Passou-se a diferenciar a atuação dos AIS de acordo com seu estágio de desenvolvimento profissional e características das comunidades compondo-se dois perfis de trabalho: de promoção e de intervenção em saúde, considerando as atividades práticas desenvolvidas nas diferentes áreas: saúde "geral", odontologia e laboratório (Anexos 8 e 9).

A preocupação em se delinear um perfil profissional visava orientar o preparo e acompanhamento do grupo de AIS pelos profissionais universitários recém contratados pelo convênio UNIFESP/FUNASA, relativo ao DISEI Xingu.

A implantação dos Distritos Sanitários Indígenas em todo país e as mudanças legislativas na área da educação profissional modificaram o cenário de atuação e as demandas de preparo dos AIS, configurando a necessidade de sistematizar um trajeto de profissionalização na área da saúde, que contemplasse 0 acesso à educação fundamental e o desenvolvimento de cursos flexíveis, de caráter modular e progressivo.

A experiência do Xingu tomada como referência para organizar a política de formação de agentes indígenas de saúde pelo Ministério da Saúde/FUNASA. A UNIFESP participou de um grupo de trabalho que desenvolveu os perfis, competências e conteúdos curriculares, de acordo com as exigências legais.

A conclusão da formação de profissionais auxiliares de enfermagem indígenas em 2001 tornou-se um marco na profissionalização dos indios do parque, juntamente com a formação dos professores indígenas, que passaram a atuar na posição de formadores, e não mais como alunos. A semelhança da área da saúde, na educação houve dificuldades quanto à institucionalização do processo de formação de professores nos níveis estadual e municipal, na regularização dos convênios e na formação de 
diretores para as escolas. O momento presente é de consolidação de alguns trajetos de formação nas áreas de educação, saúde, vigilância ambiental e desenvolvimento econômico sustentado, promovendo um exercício de novas perspectivas, centradas nos princípios pedagógicos da transversalidade dos temas e conceitos na aprendizagem e na interdisciplinaridade na construção do conhecimento.

Há um grupo emergente de profissionais sui generis, e não apenas trabalhadores indigenas treinados em papéis substitutivos das funções "do branco", indicando que a profissionalização dos índios do Xingu parece ser ampla e definitiva. Seu impacto sócio-cultural já vem sendo sentido e necessita ser refletido e avaliado por todos os envolvidos.

\subsubsection{O Processo de Trabalho e Recursos Humanos no DISEI Xingu}

Estão sendo trazidos para esta descrição alguns aspectos vivenciados no trabalho de gestão de recursos humanos realizado na construção do DISEI Xingu. Trata-se de uma experiência em andamento, centrada no princípio pedagógico do trabalho (DAVINI e HADDAD 1991).

A polêmica sobre recursos humanos ( $\mathrm{RH}$ ) em saúde é antiga. Cunhada nos anos 60, a expressão RH adquiriu um caráter utilitário, associada a materiais, insumos, e demais elementos que relacionavam quadros quantitativos de pessoal à dados demográficos e indicadores de saúde. Nessa perspectiva, a formação profissional colocava-se como uma ação modernizadora, individual e resolutiva, voltada à aquisição de habilidades técnicas para o trabalho (OLIVEIRA 1996).

A incorporação dos conceitos da economia política passou a considerar recursos humanos na vertente oposta, enquanto sujeitos do 
processo de produção em saúde, situados em um contexto histórico-social determinante de suas práticas (SCHRAIBER e PEDUZZI 1991).

A polêmica não se dá apenas na concepção de recursos humanos, desdobra-se nas relações, modos de gestão de pessoal e perspectivas de trabalho. No caso específico da saúde, os trabalhadores situam-se no centro das contradições que se estabelecem entre as necessidades de saúde da população, seus interesses profissionais e um sistema de saúde incapaz de responder satisfatoriamente a ambos (CAMPOS 1997).

As mudanças advindas da globalização da economia na década de 90 determinaram novas formas de regulação do mercado de trabalho e das condições de trabalho em saúde, que vêm se refletindo na formação e qualificação de recursos humanos na área (NOGUEIRA e col. 2000).

O discurso da competência individual ganhou destaque no plano das legislações de ensino, nas prioridades das políticas públicas da área social e nos processos de profissionalização e educação profissional que passaram a ser apresentados como elementos ordenadores dos sistemas de saúde, responsáveis pela melhoria da qualidade da atenção à saúde das populações (BRASIL 1996, MINISTÉRIO DA SAÚDE 2000a).

Inserir essa temática no contexto indígena é inusual, mas estando a saúde indígena formalmente organizada enquanto um sub-sistema de saúde no âmbito do SUS, entendemos ser necessária essa aproximação. Quais seriam os reflexos imediatos dos movimentos de profissionalização de recursos humanos na especificidade da saúde indígena?

O contexto da experiência do Xingu é de um trabalho de saúde pública, orientado pela construção social de um sub-sistema que busca a efetivação do SUS nos aspectos da descentralização, financiamento, controle social e recursos humanos. A expressão maior dessa construção vem sendo os DISEI inseridos em uma realidade peculiar por ser "rural" na maioria dos 
casos e comportar grandes diferenças étnicas e culturais. As generalizações da prática nem sempre são cabiveis, razão pela qual a formulação de critérios e instrumentos de gestão para os DISEI ainda estão muito incipientes (FUNASA 2001).

Talvez o cenário predominante dos recursos humanos em saúde indígena a nível nacional seja de déficit quanti-qualitativo de profissionais, despreparo para atuação em situações de diversidade cultural, condições de trabalho adversas, alta rotatividade das equipes, ausência de tecnologias adequadas para o cotidiano e vinculação trabalhista precária.

Os profissionais envolvidos ainda expressam ou fazem ressonância das relações sociais dos espaços interculturais nos quais atuam.

A seleção e preparo dos profissionais para a saúde indígena ainda é muito incipiente em nosso meio. Grande parte dos profissionais que atuam nesse segmento é auto-didata, e foi capacitado pelo próprio trabalho.

Nesse contexto, a política de recursos humanos desenvolvida pela USMA/UNIFESP diferencia-se por estar voltada para a composição e fortalecimento de equipes multiprofissionais, com destacada participação indígena, sendo o processo de trabalho o eixo organizador da assistência à saúde, nas suas dimensões técnicas, políticas, educativas, administrativas e sócio-culturais.

Este perfil multidimensional do trabalho requer dos profissionais adequação aos diferentes cenários e instâncias de atuação. No caso do Xingu, englobam desde as aldeias até as referências especializadas e espaços político-administrativos do nivel central, todos considerados como locais estratégicos para a formação continuada de recursos humanos.

Um outro aspecto conflitante e desafiante é o da relação dicotomizada entre ensinar e trabalhar; saber e fazer; prevenir e tratar; o modo urbano e 
o modo indígena de vida, um cenário amplo no qual o processo de trabalho em saúde indígena e a formação de recursos estão inseridos.

Formalmente, o DISEI Xingu é gerido pela UNIFESP mediante convênio com a Fundação Nacional de Saúde. A execução é de responsabilidade do Projeto Xingu, vinculado a Unidade de Saúde e Meio Ambiente do Departamento de Medicina Preventiva.

A estrutura do DISEI Xingu privilegia as ações de formação de recursos humanos, com prioridade à profissionalização indígena e capacitação de profissionais de nível universitário e às atividades de campo, organizadas em torno do eixo da vigilância à saúde (Anexo 10).

\section{Sujeitos do trabalho}

Mesmo sendo curto o tempo da implantação dos DISEI, cabe a discussão: em que território estariam atuando esses profissionais? Qual o impacto do trabalho? Quais as diretrizes orientadoras das suas ações?

$\mathrm{Na}$ realidade do DISEI Xingu, o quadro de profissionais foi estabelecido considerando a história do trabalho, diversidade cultural dos povos, o perfil epidemiológico da população atendida e as estratégias de abordagem do componente saúde em seus aspectos clínicos, educativos e epidemiológicos. O desenho proposto abrangeu as seguintes categorias: médicos, enfermeiros, antropólogo da saúde, odontólogos, etnomatemático, auxiliares de enfermagem não índios, auxiliares de enfermagem indígenas, agentes indígenas de saúde, coordenadores de saúde das áreas de abrangência, secretárias, pessoal de apoio administrativo e operacional. No final de 2001, um grupo de 65 pessoas fixas trabalhava no DISEI Xingu. A prioridade de atuação para toda equipe é no campo. 
O quadro de recursos humanos é o seguinte:

QUADRO 2 - Recursos Humanos do DISEI Xingu segundo função. Situação em 2001 e meta para 2002.

\begin{tabular}{|l|c|c|}
\hline \multicolumn{1}{|c|}{ Função } & Situação 2001 & Meta 2002 \\
\hline Médico & 2 & 3 \\
\hline Odontólogo & 2 & 2 \\
\hline Enfermeiro & 6 & 7 \\
\hline Antropólogo & 1 & 1 \\
\hline Etnomatemático & 1 & 1 \\
\hline Motorista & 3 & 3 \\
\hline Coordenador indígena de saúde & 3 & 3 \\
\hline Secretária & 2 & 3 \\
\hline Aux.enf não indigena & 8 & 9 \\
\hline Aux.enf indígena & 0 & 14 \\
\hline AIS & 24 & 30 \\
\hline Aux. Adm. & 4 & 4 \\
\hline Apoio & 12 & 12 \\
\hline Total & 65 & 80 \\
\hline
\end{tabular}

O quadro de profissionais vem aumentando e se diversificando desde 1999.

O maior crescimento ocorre nas áreas de apoio e administração, desde o início identificadas como frágeis no processo de implantação do distrito e na contratação de indígenas. Dentre os profissionais de nivel universitário, a maior dificuldade está na contratação e permanência de 
médicos, talvez em função das características do mercado de trabalho e perfil dos profissionais e da alta rotatividade das equipes como um todo.

Os lugares de trabalho, considerados por conseqüência locais de ensino-aprendizagem são: aldeia, pólo-base e cidades.

\section{Aldeia}

A aldeia indígena é a porta de entrada para o sistema de saúde (Anexo 11). Seria esse o lugar prioritário para as atividades educativas e de promoção da saúde. Ali inicia-se o processo de ensino-aprendizagem no trabalho para toda a equipe. Os profissionais de nível universitário devem deslocar-se para as aldeias, compondo equipes de trabalho com os agentes de saúde locais. Reproduzimos abaixo algumas opiniões dos índios sobre o assunto:

"O curso é muito bom, mas ele não pode acontecer só aqui (no pólobase). Tem que continuar na aldeia, na supervisão".

Puran Kaiabi, auxiliar de enfermagem indigena, avaliando um treinamento de microscopia para malária, dezembro de 2001.

"Sabe, os antigos viajavam para aprender. Eu gosto dessas viagens, de conversar no barco, eu aprendo muito, não gosto de aprender na escola, fico doido na escola" Tamarikô Juruna, auxiliar de enfermagem indígena, em uma viagem de trabalho, novembro de 2000.

"Agora eu estou gostando do distrito. O distrito vem aqui, traz o remédio, faz conversinha de noite com a comunidade, explica o trabalho para os agentes de saúde. Pode comer a carne da anta que eu matei para vocês, vamos ficar fortes juntos"

Piaui Kaibi, liderança Kaiabi, na aldeia Ilha Grande.

Além das dificuldades logísticas para o deslocamento é difícil para os profissionais "da cidade" visualizarem a aldeia como um espaço de ensino e trabalho. A experiência do Xingu aponta para a melhoria na organização e infra-estrutura de saúde local, com a construção e equipamento de mini- 
postos de saúde, a valorização do papel do AIS nas aldeias mediante supervisões profissionais contínuas e o exercício de compreender as viagens viajando, aprender a ensinar viajando, planejando e avaliando ações especificas e concretas de vigilância à saúde.

Outro aspecto importante é a normalização do trabalho mediante a uniformização de esquemas de tratamento médico e padronização de condutas desde o nível das aldeias, percorrendo um fluxo de complexidade na intervenção que assegure a qualidade técnica e mantenha a abordagem epidemiológica dos agravos de saúde.

\section{Pólo-base}

Os pólo-base são uma instância de atenção básica à saúde e sede de trabalho dos profissionais de saúde.

No Xingu, o território do DISEI foi dividido em três áreas de abrangência. Nas sedes dessas áreas, correspondentes ao postos indígenas (PI) Leonardo, Pavuru e Diauarum, três unidades básicas de saúde (UBS) foram reformadas, visando o trabalho integrado das equipes de saúde (USMA/UNIFESP 1999b).

A presença do pólo-base na área indígena e não na cidade, seria uma garantia da continuidade e do acesso a assistência de qualidade.

O desenho do DISEI Xingu estabelece que as UBS devem realizar consultas médicas e odontológicas, atendimentos de enfermagem e basear intervenções programáticas como imunização e DST. Não raro transformamse em unidades de pronto atendimento e internação, funcionando 24 horas e realizando procedimentos mais complexos como suturas, pequenas cirurgias e partos, com conseqüente excesso de trabalho e desgaste físico e emocional para os profissionais em campo, normalmente equipes restritas. 
Os problemas de remoção e morosidade nas referências de atendimento médico nas cidades, à semelhança do que ocorre no SUS como um todo, explicam parte dessa situação.

Mas há que se considerar também as dificuldades de compreensão do processo de trabalho pelos profissionais, que tendem a reproduzir os modelos medicalizantes das cidades. Sendo o pólo base centrado em um município, a medicalização é ainda maior.

Responsabilizar médicos individualmente pela assistência à populações geograficamente dispersas e em condições de difícil acesso é uma situação pouco discutida; por outro lado, deslocar o eixo do trabalho do antendimento médico individual para a produção coletiva de saúde para uma população com níveis de saúde precários torna-se um grande desafio. Percebe-se que há uma carência instrumental para intervenções no plano da responsabilidade sanitária dessas populações.

Do ponto de vista educativo, os pólo-base também são importantes locais de ensino e de interação com lideranças, professores indígenas e profissionais de outras áreas profissionais que estejam no Xingu.

"Gosto muito de assistir o trabalho de vocês no posto (pólo-base). Aqui a gente aprende muita coisa olhando, acontece muitos casos, tem muita palavra nova para falar e escrever"

Trauim Kamayurá, agente indigena de saúde, avaliando um treinamento prático no PI Leonardo, 2000.

\section{Cidades}

Nas cidades, geralmente próximas das áreas indígenas, são organizados a maior parte dos escritórios e as sedes administrativas dos distritos. Há ainda casas de apoio a pacientes e acompanhantes em tratamento de saúde. Esses espaços comportam a presença de profissionais 
indígenas e não indigenas, que atendem aos pacientes, coordenam, planejam e avaliam o trabalho e desenvolvem ações administrativas.

As sedes de Distrito deveriam ainda garantir o aporte de recursos (medicamentos, equipamentos e insumos), consolidar e gerenciar o fluxo de informações demográficas, epidemiológicas e de produção dos serviços de saúde, elementos estratégicos para organização do processo de trabalho.

As dificuldades em atingir esses objetivos são muitas, pelas excessivas demandas que surgem da área indígena, em sua maioria não relacionadas ao trabalho de saúde, solicitações de acompanhantes e lideranças indígenas em trânsito e requisições do nível central da FUNASA. Falta pessoal capacitado para filtrar essas demandas, se é que isso é possivel, e infraestrutura como equipamentos de informática funcionantes em locais distantes e isolados.

Existem ainda muitos preconceitos e dificuldades de compreensão do trabalho por parte dos gestores municipais e demais envolvidos na assistência aos índios nas pequenas cidades.

O fluxo de trabalho do DISEI Xingu, na cidade de Canarana/MT, é ainda mais pulverizado: há a necessidade de comunicação diária com a universidade em São Paulo, de onde partem os equipamentos, medicamentos, insumos e equipes de trabalho.

Estamos compreendendo que além da casa de saúde do índio, onde ocorrem intervenções técnicas, a capacitação administrativa e política poderia ocorrer na sede distrital e nas cidades para toda a equipe. Os envolvidos e não só a coordenação do trabalho devem participar de encontros e reuniões, em Canarana, Brasília e São Paulo, inclusive conselheiros de saúde e lideranças indígenas a fim de viabilizar a construção da organização e gestão do trabalho na perspectiva da interculturalidade e do controle social. 
Um aspecto crítico nesse processo é a inserção institucional dos profissionais em seu conjunto, notadamente os indígenas.

Os trabalhadores indígenas no DISEI Xingu vêm aumentando progressivamente seu espaço de atuação, participação e diversificação de funções como:

1. agentes indígenas de saúde, incluindo-se os agentes indígenas de saúde bucal e de saneamento, que atuam nas aldeias;

2. auxiliares de enfermagem indígenas, alguns atuando como coordenadores de saúde dos pólo-base;

3. auxiliares de serviços e pilotos de barco nas áreas de apoio e;

4. auxiliares administrativos na sede do distrito.

Observa-se de imediato um adensamento de responsabilidades dos trabalhadores indígenas, conseqüente à essa complexidade que extrapola a dimensão técnica da atenção básica à saúde.

Outra dificuldade imediata é o vínculo empregatício. Profissionais mais qualificados, em sua maioria não indígenas, que atendem os requisitos de contratação preconizados por lei, têm seus contratos pela CLT (Consolidação das Leis Trabalhistas), enquanto que a maior parte dos índios trabalha sem contrato, como colaboradores eventuais e prestadores de serviço, situação demonstrada no Gráfico 2. 
Gráfico 2. Vínculo dos trabalhadores indígenas de acordo com o contrato de trabalho, DISEI Xingu, 2001.

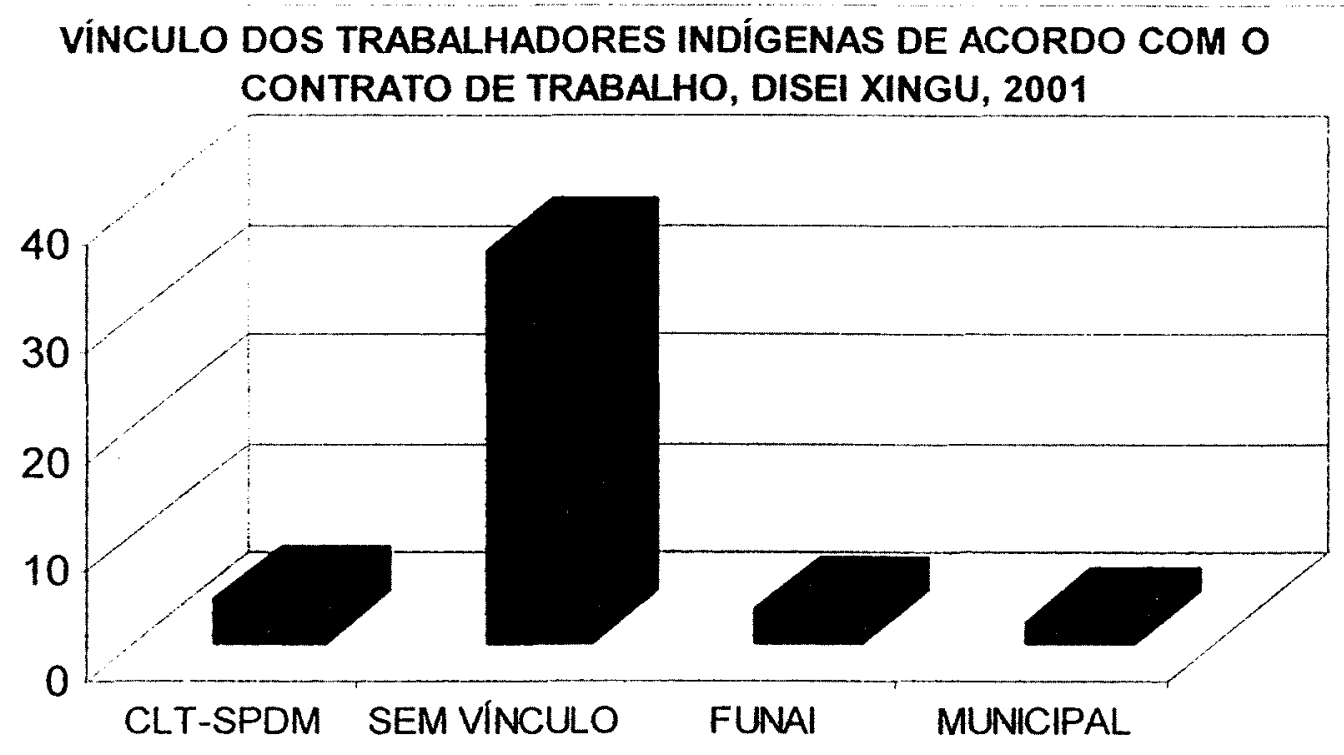

Há que se fazer um exercício crítico e constante para não reproduzir as perversidades da divisão social e técnica do trabalho nas áreas indígenas. No Xingu, a discussão vem se dando no fortalecimento do trabalho em equipe, na manutenção de níveis salariais semelhantes, independendo da função, e na busca de soluções pactuadas para legitimar e legalizar o trabalho dos índios.

Refletindo o movimento de expansão do número de trabalhadores indígenas na saúde, o padrão de remuneração também está sendo modificando.

Em um processo marcado por tantos novos elementos, quais seriam as bases da profissionalização e capacitação para os índios, capazes de assegurar seus direitos trabalhistas e adequadas ao seu perfil social enquanto trabalhadores sui generis de um novo processo de trabalho? (NOGUEIRA e col. 2000). 
O DISEI Xingu vem praticando níveis de remuneração para os índios acima da média nacional, de $R \$ 180,00$. O pagamento mir. o mensal e que abrange a maior parte dos trabalhadores no distrito é de $R \$ 250,00$, como demonstra o gráfico abaixo:

Gráfico 3. Remuneração em reais dos trabalhadores indígenas do DISEI Xingu, de acordo com a função, 1998 - 2001.

\section{REMUNERAÇÃO EM REAIS DOS TRABALHADORES INDÍGENAS DO XINGU, DE ACORDO COM A FUNÇÃO, 1998-2001}

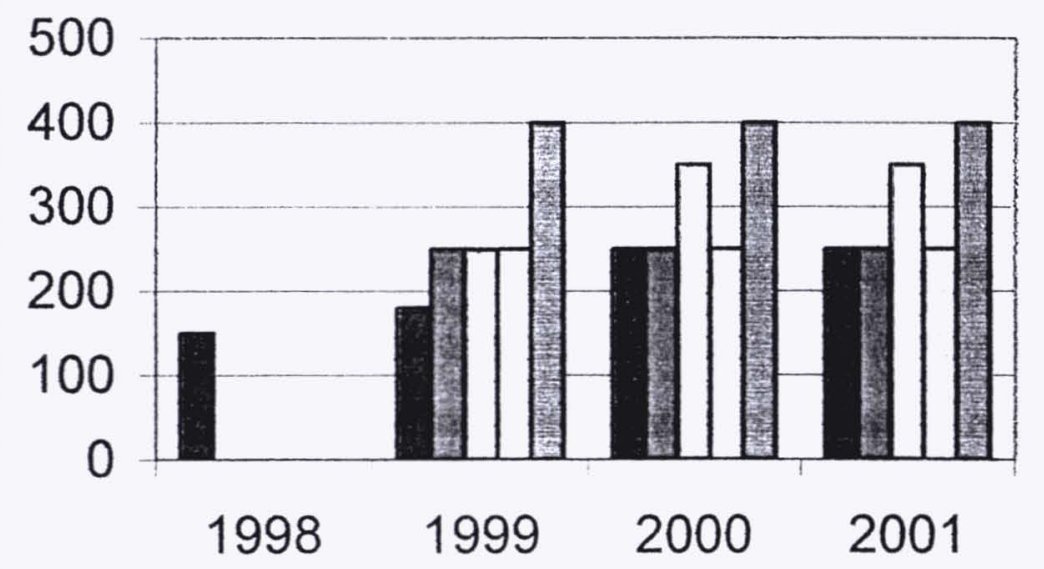

Agentes de saúde 圆Auxiliar de serviços

$\square$ Auxiliar administrativo $\square$ Piloto de barco

口Coordenador de saúde

São muitos os aspectos difíceis e conflituosos que emergem quando se faz uma abordagem crítica, o que não significa pessimista, sobre o processo de trabalho.

Melhorar a comunicação, profissionalizar o trabalho administrativo e incrementar o diálogo entre o modo indígena de gestão e a burocracia pública são algumas "pistas" que estão surgindo após três anos de intenso trabalho. 
Observa-se que há um longo caminho a ser percorrido em direção à legitimação do trabalho. A expressão utilizada no período da colonização e citada por RIBEIRO (1997) que se referia aos índios e negros como "gentes de serviço", fáceis de se gastar e repor, e socialmente inferiorizados infelizmente ainda se aplica à um grande contingente de trabalhadores brasileiros sem a devida qualificação, incapazes de atender as exigências formais de um mercado de trabalho cada vez mais rigoroso e precário.

O caminho da profissionalização em serviço, trilhado no Xingu desde 1990, apresenta-se como uma tentativa de reversão desse quadro.

\subsubsection{Estrutura dos cursos de saúde: do treinamento à formação}

Desde 1990 os cursos oferecidos na área da saúde, para agentes de saúde, auxiliares de enfermagem e outros correlatos vêm se organizando de forma modular nos postos indígenas, integrando a teoria, ministrada intensivamente em periodos de 15 a 30 dias, com carga horária entre 120 $160 \mathrm{~h}$, e a prática desenvolvida nas comunidades em forma de rodízio nas UBS dos postos indígenas e nas aldeias. No planejamento dos conteúdos, observa-se a crescente valorização da comunidade indígena e seus espaços de vida, como objeto do trabalho e estudo e não apenas o indivíduo doente (Anexo 12).

Os momentos de prática desde o início abrangiam o exercício da escrita, leitura e matemática de forma assistemática e de acordo com as demandas individuais dos alunos.

A partir de 1995, as discussões sobre organização de serviços de saúde, política de saúde e qualidade de vida ficaram mais delineadas, assim como a perspectiva intersetorial da intervenção, agregada as áreas de educação, vigilância e meio ambiente (USMA/UNIFESP 1995). 
Os diferentes relatórios analisados refletem o perfil pessoal $\mathrm{e}$ profissional dos professores, revelando uma ampla gama de olhares. Alguns se centravam mais nas mudanças comportamentais e habilidades técnicas dos educandos adquiridas nos cursos. Outros, mais abrangentes, enfocavam o modo de vida nas comunidades e suas relações com a saúde. Os relatórios elaborados pela coordenação do curso abordavam aspectos políticos, antropológicos e metodológicos da formação.

Os cursos buscaram seguir uma dinâmica articulada entre teoria e prática, denominada nesse processo de Concentração e Dispersão.

A Concentração refere-se ao momento do curso em que todos os alunos encontram-se juntos (concentrados) na sede de uma das áreas de abrangência dentro do parque, o espaço de vida e trabalho dos AIS. Os professores se deslocavam para dar aulas, geralmente vindos de São Paulo. Os períodos de Concentração são caracterizados pela reflexão/teorização da prática profissional. São considerados como momentos de reconstrução teórica de formas, princípios científicos mais elaborados e que buscam instrumentalizar e explicitar a prática profissional. Sob a orientação direta de um professor ou instrutor, capacitado técnica e pedagogicamente, os alunos desenvolvem atividades programadas (MINISTÉRIO DA SAÚDE 1994). São discutidas as questões referentes a sua prática cotidiana, e desenvolvidos novos conhecimentos e habilidades que objetivam instrumentalizar os alunos para uma ação profissional diferente.

A Dispersão é o momento do curso destinado ao desenvolvimento das habilidades práticas. Os alunos estão distribuídos (dispersos) em diferentes unidades de atendimento posto de saúde ou aldeia de origem,onde trabalham integrados a equipe de saúde. Na Dispersão há orientação, acompanhamento e registro sistemático do desenvolvimento do educando. Este momento visa a favorecer a reflexão de cada aluno no universo das funções para as quais está se habilitando. É na Dispersão que ocorre uma 
nova sistematização dos conhecimentos e a sua consolidação. Esse momento acontece após cada período de Concentração ou paralelamente a ele. O instrutor da Dispersão é o profissional de campo que trabalha na unidade de saúde, na mesma equipe do aluno. As atividades de Dispersão no Xingu geralmente se organizam como viagens de supervisão, nas quais um grupo de profissionais é mobilizado para desenvolver ações diversas, dentre as quais o acompanhamento prático dos alunos. Mesmo orientada por esses pressupostos, a organização dos momentos teóricos parece ser divergente da prática. Os relatórios analisados sobre o trabalho prático, ou supervisão, foram elaborados em sua maioria por profissionais menos experientes, geralmente enfermeiros, e demonstravam uma preocupação e mesmo ansiedade em resolver as demandas clínicas imediatas das comunidades, separando-as da formação. Os agentes de saúde eram vistos em diferentes níveis, com uma certa distância dos profissionais e sempre em um movimento muito dinâmico, compondo uma espécie de hierarquia. Para fins didáticos, em caráter provisório optamos por compor a seguinte classificação:

1. arrolados, os autodenominados AIS, participantes dos cursos, e assim referidos pelas comunidades;

2. treinados, os que acompanhavam o trabalho de perto, participavam dos cursos teóricos, das atividades práticas e do trabalho cotidiano; tendo documentação e fichas de avaliação relativas ao trabalho de supervisão;

3. efetivos, os AIS que estavam de fato presentes no dia a dia, com documentação indicativa do seu acompanhamento e relatórios de trabalho;

4. remunerados, pessoas inseridas no trabalho, participantes dos cursos e supervisões, geralmente com maior experiência e que recebiam remuneração. 
Gráfico 4. Situação de treinamento e trabalho dos AIS no Xingu, 1998 a 2001.

\section{SITUAÇÃO DE TREINAMENTO E TRABALHO DOS AIS NO XINGU, 1998-2001}

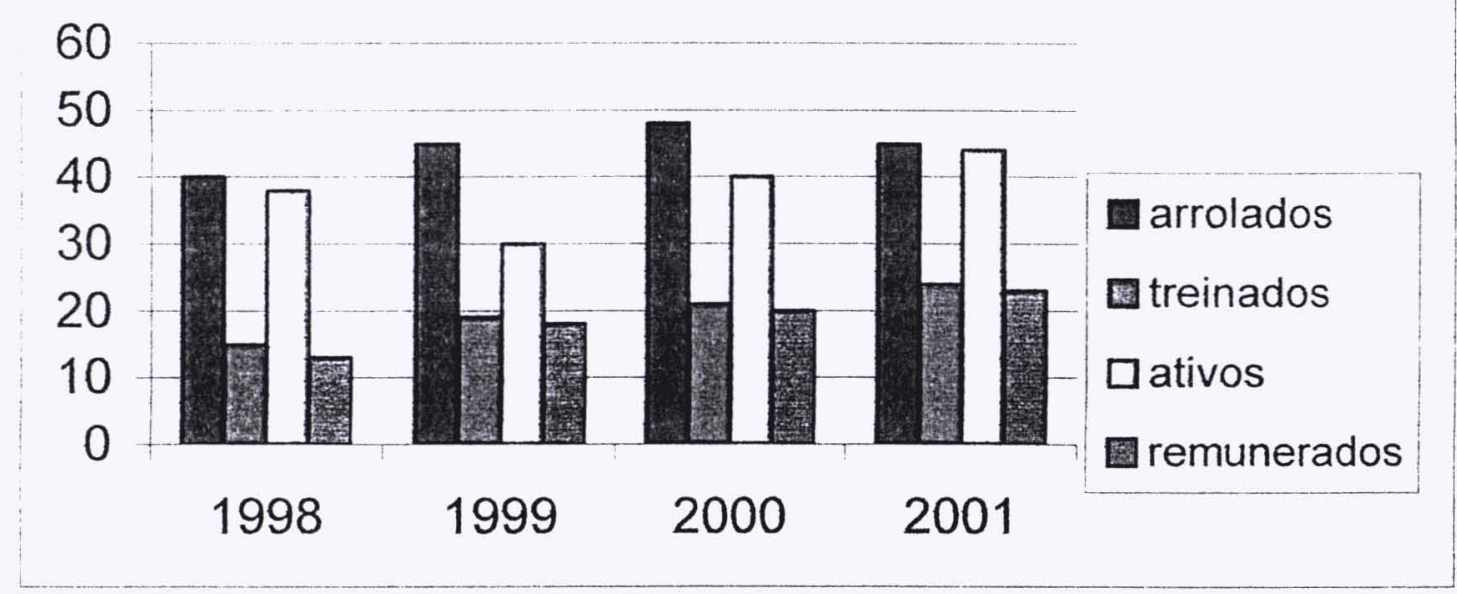

Observa-se que o número de agentes de saúde vêm aumentando desde 1998, com a sistematização do acompanhamento prático e remuneração. Constatou-se que há um movimento de aproximação e afastamento em torno dos cursos e do trabalho, uma espécie de "flutuação", que se assemelha aos ciclos de vida e modos de trabalho das culturas do Xingu e que necessita ser melhor compreendido, na perspectiva das diferenças culturais.

Os modelos de trabalho existentes em saúde indígena tendem a reproduzir o ritmo de trabalho das instituições de saúde e apenas tangenciam tais diferenças. 


\subsubsection{Organização dos conteúdos}

"Eu tenho para mim que o mais importante para aprender é ser paciente.

Tenho muita dificuldade, falta branco aqui para explicar.

Eu tinha medo de matar, de fazer de qualquer jeito, mas nunca matei ninguém, era a toa mesmo, (medo), fiquei aprendendo aos poucos com os meus amigos.

Quero saber como ficam as lesões de pele, quero saber fazer curativo, de pneumonia eu entendo um pouquinho, já sei fazer o esquema (de tratamento), entendi porque vocês explicaram dentro do esquema nos últimos cursos".

Preayup Kaiabi, auxiliar de enfermagem indigena, 2000.

Os cursos ministrados nos primeiros anos enfocavam as doenças mais prevalentes na área, refletindo a preocupação em capacitar os AIS para a intervenções clínicas, como demonstra o quadro abaixo:

QUADRO 3 - Temas desenvolvidos e número de participantes dos cursos de formação de agentes de saúde, do DISEI Xingu, 1991 a 1996.

\begin{tabular}{|l|l|c|}
\hline Período & \multicolumn{1}{|c|}{ Tema } & $\begin{array}{c}\text { Número de AIS } \\
\text { participantes }\end{array}$ \\
\hline Julho/91 & Doenças diarréicas/ cólera & 28 \\
\hline Julho/92 & Doenças respiratórias/tuberculose & 35 \\
\hline Julho/93 & Doenças sexualmente transmissiveis/AIDS & 57 \\
\hline Julho/94 & Malária, tuberculose, saneamento & 45 \\
\hline Julho/95 & $\begin{array}{l}\text { Reciclagem em: abordagem do doente, exame } \\
\text { clínico, técnicas de enfermagem e saneamento }\end{array}$ & 46 \\
\hline Julho/96 & $\begin{array}{l}\text { Vigilância Epidemiológica: Imunização, malária, } \\
\text { tuberculose e saneamento }\end{array}$ & 43 \\
\hline
\end{tabular}

Em 1996, ganha consistência a preocupação em estruturar a formação mediante a organização curricular dos conteúdos, instrumentos de avaliação 
e definição das responsabilidades institucionais. A parceria com a Escola Técnica de Saúde do Mato Grosso, estabelecida em 1997, com vistas a legitimar a profissionalização dos auxiliares de enfermagem indígenas aproximou o processo de formação das questões legais e técnicas referentes a educação profissional de níveis básico e técnico. Para melhor compreensão dos aspectos legais dos percursos de profissionalização admitidos em Lei, consultar o Anexo 13.

O novo marco conceitual advindo das leis preconiza que os currículos na educação profissional sejam baseados na análise do processo produtivo de cada área profissional.

Uma série de documentos, pareceres e estudos foram produzidos no período, na tentativa de decodificar os princípios legais, inclusive na esfera indígena (BRASIL 2000).

A legislação considera que as etapas do mundo do trabalho subsidiem o desenho das competências ${ }^{\mathrm{xi}}$, enquanto experiências a serem construídas pelos estudantes em seu caminho de aprendizagem. As recomendações abrangem o desenvolvimento de metodologias de ensino nas quais os saberes sejam apropriados para gerar habilidades. Os projetos curriculares começaram a ganhar organicidade, flexibilidade e adequação. A aplicação do princípio da flexibilização curricular passou a valorizar as características étnicas e regionais dos alunos e os processos ensino - aprendizagem críticos, solidários e transformadores da ação educativa.

A área de educação escolar indígena avançou substancialmente esta discussão, no plano conceitual e metodológico (MINISTÉRIO DA EDUCAÇÃO 2000). Talvez uma grande contribuição dessa nova realidade seja a necessidade dos educadores conhecerem, vivenciarem, valorizarem e

\footnotetext{
${ }^{x}$ A legislação de ensino trata das competências enquanto um conjunto de operaçōes sócioafetivas, psicomotoras e cognitivas necessárias ao processo de aprendizagem (Ministério da Educação, 2000).
} 
aplicarem os conhecimentos tradicionais e originários das comunidades de seus alunos.

No contexto da saúde, essas novas proposições se traduzem da seguinte forma: não basta treinar, é preciso formar. O processo de ensinar deve integrar contextos, e sempre partir do perfil dos alunos, significando que o professor deve conhecer e participar da realidade sócio-cultural na qual está inserido. Não basta mais oferecer treinamentos sobre procedimentos de enfermagem, ou capacitações técnicas de modo impessoal e distanciado. É preciso formar no trabalho, com competência e legitimidade.

Essas novas discussões re-orientaram os processos dos cursos de saúde no Xingu nas seguintes perspectivas:

- composição dos temas interdisciplinares nas áreas técnicas, pedagógica e política;

- transição dos conteúdos que partiam do tratamento de doenças para elementos de saúde pública como vigilância epidemiológica, imunização, controle de malária, tuberculose e finalmente vigilância à saúde, cidadania e qualidade de vida;

- apropriação do movimento dialógico e progressivo da aprendizagem, manifesto na identificação e construção de conceitos nucleadores e eixos de conhecimento para cada área temática;

- progressiva inclusão do núcleo comum relativo ao ensino fundamental nos cursos;

- atendimento aos requisitos legais da LDBE/96 e Decreto 2208/98;

- promoção das qualidades investigativas, criativas e lúdicas dos alunos. 
QUADRO 4 - Cursos de saúde segundo período, tema e participantes. Xingu, 1997 a 2001.

\begin{tabular}{|l|l|l|}
\hline \multicolumn{1}{|c|}{ Curso } & \multicolumn{1}{|c|}{ Tema } & Participantes \\
\hline $7^{\circ}$ Curso/novembro 1997 & $\begin{array}{l}\text { Prevenindo risco na relação } \\
\text { intercultural e na mudança de } \\
\text { hábitos/costumes, rompendo a a } \\
\text { cadeia de transmissão de } \\
\text { doenças }\end{array}$ & $\begin{array}{l}38 \text {, sendo:11 AISB; } \\
\text { indígenas e 11 AIS }\end{array}$ \\
\hline $8^{\circ}$ Curso/dezembro 1997 & $\begin{array}{l}\text { Rompendo a cadeia de } \\
\text { transmissão de doenças/ } \\
\text { prevenindo o risco na relação } \\
\text { intercultural }\end{array}$ & 17 AEI \\
\hline Cursos a partir de 1998 & $\begin{array}{l}\text { Aplicação do currículo integrado } \\
\text { para os AIE e oficinas de } \\
\text { trabalho para AIS }\end{array}$ & 17 AEI e 40 AIS \\
\hline $\begin{array}{l}\text { Oficina de trabalho, set. } \\
1999\end{array}$ & $\begin{array}{l}\text { Avaliação do curso de AIE e e } \\
\text { introdução ao trabalho para AIS }\end{array}$ & 17 AEI e 5 AIS \\
\hline $\begin{array}{l}\text { Módulo Introdutório, dez } \\
2000\end{array}$ & Adaptação da Proposta Funasa & 12 AIS do Alto \\
\hline Curso julho 2001 & $\begin{array}{l}\text { Processo de trabalho no DISEI } \\
\text { Vigilância à saúde da criança }\end{array}$ & 22 AIS e 4 AEI \\
\hline
\end{tabular}

A partir de 1998, o processo de formação dos AIS passou a ser estruturado em função do curso de auxiliar de enfermagem indígena, e aparentemente ficou em plano secundário. Mas os espaços de discussão e planejamento educativo se ampliaram e continuaram articulando o trabalho de saúde e com a realidade de vida do Xingu. Em março de 1999 uma oficina pedagógica realizada em São Paulo em parceria com a ETS e o ISA delimitou um panorama da formação para indígenas e discutiu as perspectivas de entrelaçamento de aspectos políticos, legais, técnicos, pedagógicos e antropológicos nas várias esferas de formação: saúde, economia, educação. A carência de instrumentos pedagógicos facilitadores da articulação de 
conteúdos e conceitos foi um dos pontos críticos apontado por todo grupo (USMA/UNIFESP1996).

Um caminho possivel de resolução seria o exercitar contínuo de tal articulação no planejamento curricular, calcada nos princípios da intersetorialidade, interculturalidade e participação. Reafirmou-se o compromisso de organização dos serviços de saúde mediado pela intervenção educativa, privilegiando espaços de cursos, oficinas, encontros, parcerias institucionais e intensificação do trabalho interno na área indígena (USMA/UNIFESP 1999a).

Esses encontros envolvendo agentes de diferentes instituições geravam um certo nivel de tensão, talvez pelas diferentes visões de mundo e concepções político - pedagógicas representadas, que era suplantado pela solidariedade e troca de experiências entre educadores, coordenadores e alunos.

\section{Legitimação e Certificação dos cursos}

"Eu quero conhecer esses papéis, esses certificados. Esse curso não presta, é paraguai, porque caraiba precisa de papel para saber se o curso é bom"

Tamarikô Juruna, auxiliar de enfermagem indigena, 2001 
A legitimação e certificação dos processos de aprendizagem são bastante polêmicas. Parece que vem das comunidades indígenas o primeiro movimento de legitimação da formação e trabalho dos AIS. Mesmo sendo o trabalho de saúde no Xingu bastante antigo, e a atuação de agentes de saúde considerada de grande importância pelas comunidades, as mudanças no processo de trabalho, inserção profissional e remuneração modificaram-se significativamente nos últimos anos, gerando diferentes percepções e compreensões sobre o papel dos AIS.

A legitimação do trabalho nas comunidades do Xingu não é uniforme. Os AIS iniciantes se expressam de modo a vislumbrar no trabalho perspectivas de remuneração e ascensão social e profissional, não se restringindo ao aspecto de melhoria da saúde da comunidade, discurso comum na fala dos AIS mais antigos.

"O agente de saúde deve preocupar-se com o seu povo, buscando uma boa saúde para todos" Taravi Kaiabi, AIS, Baixo Xingu, 1998.

"Não sei o que acontece. Todos querem trabalhar na comunidade. Depois que começa a ganhar o salário, muda o pensamento, só quer saber do dinheirinho, quando vai ter aumento, o material, esquece do povo"

Cacique guarani Manoel Lima, SP, 2001.

No aspecto externo, de certificação pelo Sistema de ensino, as perspectivas apontadas nos últimos anos e ainda não totalmente amadurecidas que emergem dos relatórios e discussões são da composição de um processo amplo de formação que atenda aos seguintes requisitos:

- adequação aos princípios da Lei no 9394/96 e Decreto 2208/98;

- inserção desses cursos no âmbito da educação profissional;

- formação dos AIS partindo do nível básico, com acesso ao ensino fundamental e garantia do prosseguimento dos estudos em nivel 
técnico (princípios da progressividade e flexibilidade) abrangendo novas áreas do setor saúde, como apoio diagnóstico e administração;

- utilização do instrumento convênio com instituições formadoras vinculadas ao SUS, como as escolas técnicas de saúde, para ins de certificação e acompanhamento pedagógico e;

- utilização da certificação por competências, um novo instrumento legal que atende a necessidade de legitimar e legalizar os saberes e práticas de profissionais que não tiveram acesso ao ensino formal, ainda não praticado.

\section{Metodologia de ensino}

"Como eu posso falar que a gente aprende? Acompanhando a enfermeira e perguntando muito, perguntando maior. Comecei a participar dos cursos em 1993. No primeiro curso não entendi nada, voltei zero. Em 1997 passei para auxiliar indígena, o Cláudio e Aru começaram comigo e desistiram, eu enfrentei. Vocês sabem o que os caciques falavam e até hoje falam, não posso dizer o que é. Aprenci a gostar de estudar e não esquecer, tem que estudar muito, os cursos são curtos".

AEI Tafuraki Nafukuá, explicando do trabalho de saúde para um gruo de AIS iniciantes, dez 2000.

Uma preocupação permanente nos cursos foi a identificeşão de princípios pedagógicos facilitadores da relação intercultural e que permitissem ao estudante indígena a apropriação de novos conhecimentos (USMA/UNIFESP 1997).

A necessidade de buscar metodologias adequadas para diriemizar o processo ensino-aprendizagem no marco do pensamento indígena aproximaram a construção dos cursos da pedagogia da problemetização, 
identificada com a vertente da educação histórico crítica aplicada na área da saúde desde 1982 (OLIVEIRA LSS 1996).

Várias premissas da problematização pareciam adequadas ao trabalho de saúde no Xingu: a relação entre teoria e prática, a participação do aluno como sujeito da aprendizagem, a valorização do diálogo entre o educador educando e de suas experiências e saberes prévios (FREIRE 2001).

A proposta pedagógica conhecida como "problematizadora", também reconhece a não neutralidade da produção do conhecimento, os processos sociais e culturais e as condições concretas da produção da prática profissional.

Essa metodologia tem a sustentação conceitual dos padrões culturais, que dizem respeito à visão de mundo, tradições, estrutura familiar e trajetória de formação construída pelo educando através da sua história pessoal e do grupo social ao qual pertencem, configurando seus pensamentos e percepção da realidade. Esses referenciais formam o eixo definidor dos conteúdos e das atividades didáticas de acordo com a realidade sócio cultural dos educandos (OLIVEIRA LSS 1996).

Nos últimos anos, as contribuições de Vigostky e Bernstein, citados por SÁ (2001) têm apontado para a necessidade de ampliação da práxis pedagógica nos processos de formação para o trabalho em saúde, considerando as dimensões do ambiente na determinação da estrutura do pensamento e nos códigos que dão significância ao pensamento do educando. Dão relevância a compreensão das formas de conhecer e pensar dos alunos indígenas, e da estrutura do conhecimento a ser apreendido.

Mesmo sendo aplicada há poucos anos, são muitas as evidências encontradas sobre a melhoria da qualidade do processo pedagógico desenvolvido no Xingu com a utilização da metodologia da problematização. 
Destacamos as seguintes:

1. aproximação entre teoria e prática, já que os espaços e momentos de aprendizagem passam a ocorrer no dia a dia do trabalho;

2. maior participação dos educandos, com valorização do saber prévio e das experiências anteriores dos alunos individualmente e como grupo,

3. incentivo ao trabalho em equipe;

4. sistematização e facilitação do trabalho educativo advindos da implantação dos instrumentos pedagógicos, inicialmente utilizados para avaliação: fichas de avaliação de desempenho, check-lists de técnicas, fichas de registro de fatos, prontuários individuais para os alunos, desenhos, registros de auto-avaliação e avaliação coletiva, dentre outros;

5. desenvolvimento da capacidade investigativa e criativa dos alunos;

6. solidariedade presente entre os alunos e suas famílias na conquista da profissionalização;

7. relações de mediação e complementaridade entre saberes e poderes expresso por exemplo no movimento reflexão/ação mediado pelos sábios e pajés;

8. participação ampliada de lideranças, detentores de saberes da medicina indígena e comunidade, na formação, gestão da saúde e ações de vigilância à saúde. Tomamos como exemplo a condução de reuniões do conselho de saúde e o acompanhamento do desenvolvimento infantil nas aldeias;

9. co-existência de vários mundos e saberes no processo de formação; 
10. inserção de novos sujeitos no papel de professores: pajés, lideranças e professores indígenas, AIS mais antigos;

11. consolidação de um espaço intercultural e interétnico para o ensino, ampliando e flexibilizando os princípios pedagógicos. São 14 povos vivendo, convivendo e aprendendo junto e

12. evolução metodológica no sentido de exposição dos pensamentos, questionamentos e finalmente do diálogo intercultural, interétnico e interdisciplinar.

\section{Sujeitos que ensinam}

"Há quem pense que, em decorrência do nosso longo período de convivência com o índio, não nos demos conta do passar do tempo, e não percebemos que uma geração sucedeu àquela nossa conhecida no inicio - esta, hoje, mais capacitada para resguardar sua comunidade. Nada mais tolo! A geração que aí está, de homens maduros e de alguns ainda moços, recebeu de nós os primeiros ensinamentos, até mesmo a alfabetização - uma arma a mais na defesa e na união de todos"

Orlando Villas Boas, s/d

São incontáveis os mestres no Xingu. Orlando Villas Boas foi um dos primeiros. Posteriormente, na administração de Olímpio Serra no PIX, a preparação e trabalho dos índios foi sendo ampliada.

Na área médica, o Prof. Roberto Baruzzi é freqüentemente citado como um grande mestre:

"Agora eu sou o Baruzzi. Vou ensinar sobre pneumonia" Tymain Kaiabi, auxiliar de enfermagem indigena, 1998.

O Baruzzi foi meu aluno. Eu ensinei doença do índio para ele, ele ensinou doença do branco para mim.

Pichanhã Juruna, auxiliar de enfermagem indigena, 2000. 
A percepção sobre a necessidade de ensinar e aprender saúde no Xingu não é imediata para os profissionais universitários. São múltiplas as percepções sobre o que é ensinar e refletem as concepções de mundo e experiências educativas dos profissionais. São freqüentes as solicitações dos profissionais de campo para assessoria nas áreas de educação e antropologia, para minimizar as lacunas de formação.

O despreparo dos profissionais da área da saúde para o trabalho educativo não acontece só no Xingu. Pelas características da formação, as enfermeiras são as profissionais que comumente se aproximam desse trabalho, mas o fazem de maneira empírica.

Ainda que a função educativa seja inerente ao trabalho, ela não é exercida de imediato pelos profissionais, mesmo sendo explicitada no momento de contratação dos profissionais no Projeto Xingu.

Na dimensão educativa, a atitude primeira dos supervisores é a de fiscalizar o trabalho e destacar falhas individuais, reproduzindo a prática educativa realizada no contexto hospitalar.

"Apresenta grande dificuldade na língua portuguesa, talvez por isso fique pouco atento ao material entregue nos cursos. Necessita exercitar a leitura e escrita no desempenho do dia a dia"

Gerson Santana, enfermeiro, 1999.

"A evolução dos AIS mesmo sem supervisão é notória, eles parecem andar por si próprios, mas não sabem agir com os profissionais"

Fernanda Sakamoto, médica, 2000.

"É interessado, questionador, mas resistente ao processo de supervisão, principalmente nos momentos que necessita de correções e sugestões."

Patricia Rech, enfermeira, 2001.

Com o decorrer do tempo, o envolvimento afetivo entre professores e alunos explicita-se nos relatos verbais e escritos. 
"Yanahim virou meu filho. Acompanha o tempo todo, sempre atento, faz perguntas, anotações. É muito inteligente"

Castorina Lurdes dos Santos, enfermeira, 1998.

Os AIS frequentemente fazem comparações entre os professores e profissionais que atuaram em diferentes épocas e contam histórias sobre o trabalho.

"Castorina é como mãe para nós. Quase ficou louca de tanto trabalhar, de tanto ensinar, de tanta preocupação com a gente."

Ayguré Txicão, AIS,1999

"Estela foi minha primeira professora. Aprendi ler, escrever, ver a temperatura, dar o remédio. Aprendi muita coisa com ela."

Yefuká Kaiabi, AIS, 1998

"Professora grande para mim foi a Marina. Ela me ensinou a ler, acho que foi no ano de 1992. Ela ensinou a escrever essa letra, letra de Marina. Eu uso até hoje".

Poikô Kaiabi, AIS, 1999

"Sofia é nossa chefa, nossa"cacica". Ela tem boa idéia de ensinar e trazer professores para ensinar nós."

Tymain Kaiabi, AIS, 1999

"Douglas é um grande médico, ele é planejador e professor. Estudou saúde de toda gente, a saúde pública. Escolheu um povo para planejar a saúde toda deles, ele escolheu nós. Os outros distritos não tem cara preparado para fazer o planejamento, nem em Brasilia tem. O Douglas que ensina para eles, eu vi lá. Os outros distritos cataram tudo para fazer, mas não prepararam o pessoal.

Lavínia é enfermeira mas é grande professora. Ela sabe ajudar a aprender, ela escolheu nós para ensinar."

Yanahim Waurá, Auxiliar de enfermagem indígena, 2000

A função educativa do AIS mais antigo para com os mais novos parece ser inerente ao trabalho, ao contrário do que ocorre com os profissionais vindos de fora. Eles parecem conscientes do papel de abrir caminhos e formar exemplos.

"Eu sou mestre. Meu pessoal me chama assim: mestre. Meus alunos tem que andar comigo. Trouxe dois para o curso, eles tem que andar comigo". 
Kulika Matipu AIS, dezembro de 2000.

"Desde pequeno, na barriga da mãe, as crianças já dizem: quero ser como um deles. Eu já trabalhei e estudei, agora sigam o meu caminho, vocês vão ser ainda melhores do que eu."

Yanahim Waurá, 2000

"Esse é meu filhinho, eu já to conversando com ele, se ele vai querer ser auxiliar de enfermagem indigena ou jogador de futebol.

Tafuraki Nafukuá, AEI, 2000.

\section{Sujeitos que aprendem}

Quem é o agente indigena de saúde? Para se pensar em um perfil profissional dos AIS, estamos considerando as manifestações deles sobre seu trabalho e inserção social, que são ricas e conflitantes. Refletem um trabalho intenso, muitas vezes isolado e solitário, cheio de desafios, reflexões e muita vontade de aprender. A maioria dos profissionais que interagem no processo também se colocam como aprendizes de novas realidades e em constante descoberta.

Destacamos algumas falas de AIS e AEI que são auto-explicativas:

"O agente de saúde deve estudar bem e aprender; ajudar nós mesmos e nosso povo e no futuro também ter um emprego"

Marité Txicão, AIS, 2001

"Deve preocupar-se com o seu povo, buscando uma boa saúde"

Tatiana Yawalapiti, AIS,2001

"Deve atender a qualquer hora e concordar com o pajé"

Anuiá Yawalapiti AIS, 2000

"Trabalhar junto com os médicos e com os pajés"

Trauim Kamaiurá, AIS, 2000

"O difícil é agüentar ficar sózinho com o paciente grave, a familia fica revoltado. $O$ que está acontecendo é não saber se o trabalho está sendo bem desenvolvido ou não, tem muita crítica."

Yefuká Kaiabi, AEI, 2001 
"Eu mesmo nunca enfrentei escola. Aprendi as coisas com o Maiowê $e$ as enfermeiras. Os cursos ajudaram muito no português, aprender a ler e escrever. Tenho dúvidas de doses, contar a respiração, saber a diferença de medicamentos genéricos e os outros".

Tarei Kaiabi, AEI, 2001

"O que aprendi mesmo é tratamento de IRA. O pessoal quer ter remédio. Vim fazer o curso por conta própria, a comunidade não deu respaldo. Eu saiu muito, porque não gosto de pedir nada, gosto de ir e comprar. Tenho necessidade de coisas da cidade".

Ayumã Kamaiurá, AEI, 2000.

"O povo tá bem, diminuiu muito a gripe lá por causa das vacinas, ainda dá diarréia por causa do tempo. Agora acho que avaliar é ver o trabalho. Quando é bom tenho vontade de levar o trabalho pra sempre".

Yawot Kaiabi, AEI, 2000

"Eu sentia muita vergonha porque não entendia. Antes a gente sofria muito. Eu fiquei 12 anos sem ver dinheiro, sem comer direito por causa do trabalho. Hoje tô velhinho, tenho preguiça de trabalhar na saúde e de roçar"

Taliko Kuikuro, 2000

"No começo era difícil, nem todos eram parentes, tinha um pouco de briga nos cursos, você nem viu esse tempo".

Tamarikô Juruna, AIE, 1999

"O mais importante que eu aprendi neste curso é que a paz nasce da amizade. Não dá para ter paz sem conviver, sem ficar amigo" Kanawaiuri Kamaiurá, AEI,2001

" Nunca havia viajado para este lado do Xingu. Gostei muito de conhecer esses parentes, de poder ajudar. Não somos mais inimigos"

Tareí Kaiabi, AIE, 2000.

Quanto ao alcance do trabalho, pode-se considerar que atualmente, os agentes de saúde estão presentes em praticamente todas as aldeias do Xingu, e sua atuação faz parte do cotidiano. 0 Gráfico 5 , da distribuição dos AIS por etnia, demonstra que todos os povos possuem pelo menos um agente de saúde. A predominância das etnias do Baixo Xingu reflete o processo de organização do trabalho em saúde que é mais antigo e legitimado na região, principalmente entre os Kaiabi que é também a etnia mais numerosa do Xingu. 
Gráfico 5. Distribuição dos AIS do Xingu por etnia, 2001.

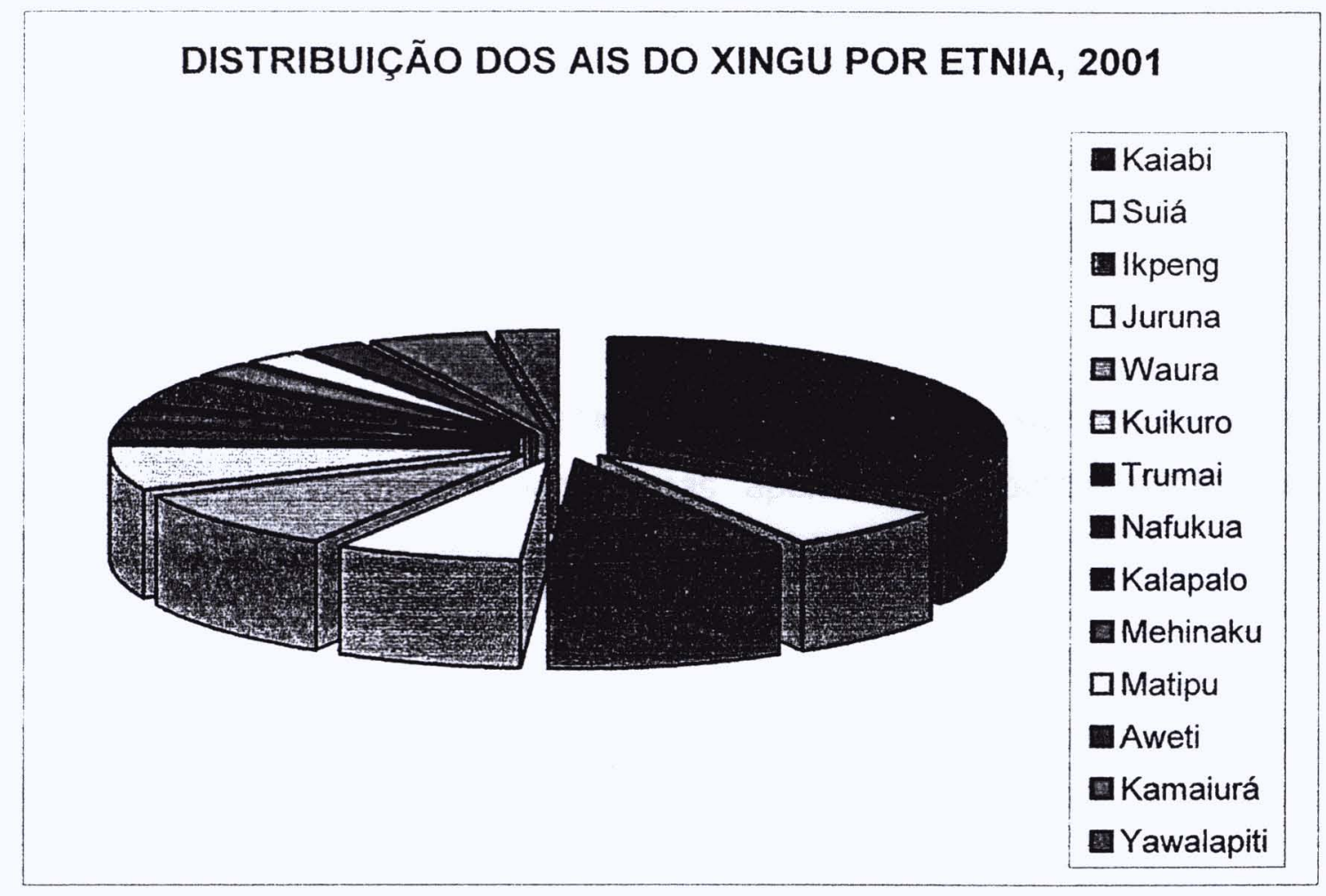

O perfil pessoal dos indígenas que atuam na área de saúde no cenário latino americano é bastante heterogêneo. Na Venezuela e em menor escala Colômbia, são comuns a atuação de mulheres maduras nas áreas de saúde da criança e assistência ao parto (HERRERA e LOBO, 1998). No Brasil e no Xingu predominam os jovens do sexo masculino, que são interlocutores das comunidades para diversos assuntos.

Ao contrário do conjunto do país, no qual a proporção de mulheres passa dos $90 \%$, na realidade indígena o predomínio de agentes de saúde é masculino. Estes cargos estão associados a existência de normas culturais que distanciam as mulheres dos brancos, que têm múltiplas obrigações familiares e pouca compreensão do português.

Este estudo confirma que os AIS brasileiros geralmente são jovens do sexo masculino, dominam a língua portuguesa e algumas práticas do sistema 
tradicional de cura e exercem influência política em suas comunidades. (FUNASA 1999, USMA/UNIFESP 2000).

No Xingu, até 1998 todos os jovens inseridos no trabalho eram do sexo masculino, na faixa etária dos 13 aos 45 anos. Algumas mulheres se interessavam pelo trabalho, mas devido a dinâmica social não permaneciam após o casamento e nascimento dos filhos.

Nos últimos anos a participação das mulheres no trabalho e nos cursos aumentou discretamente, mas apenas uma delas, uma mulher solteira, de 22 anos permanece no trabalho há dois anos.

Outra tendência que começa a ser esboçada é a da diversificação do trabalho. As opções de trabalho formal e remuneração nas áreas indígenas vêm aumentando em número e complexidade. O Gráfico 6 demonstra as funções existentes para os indígenas no DISEI Xingu:

Gráfico 6. Distribuição dos trabalhadores indígenas do Xingu segundo função, 1998 a 2001.

\section{DISTRIBUIÇÃO DOS TRABALHADORES INDÍGENAS DO XINGU, SEGUNDO FUNÇÃO 1998-2001}

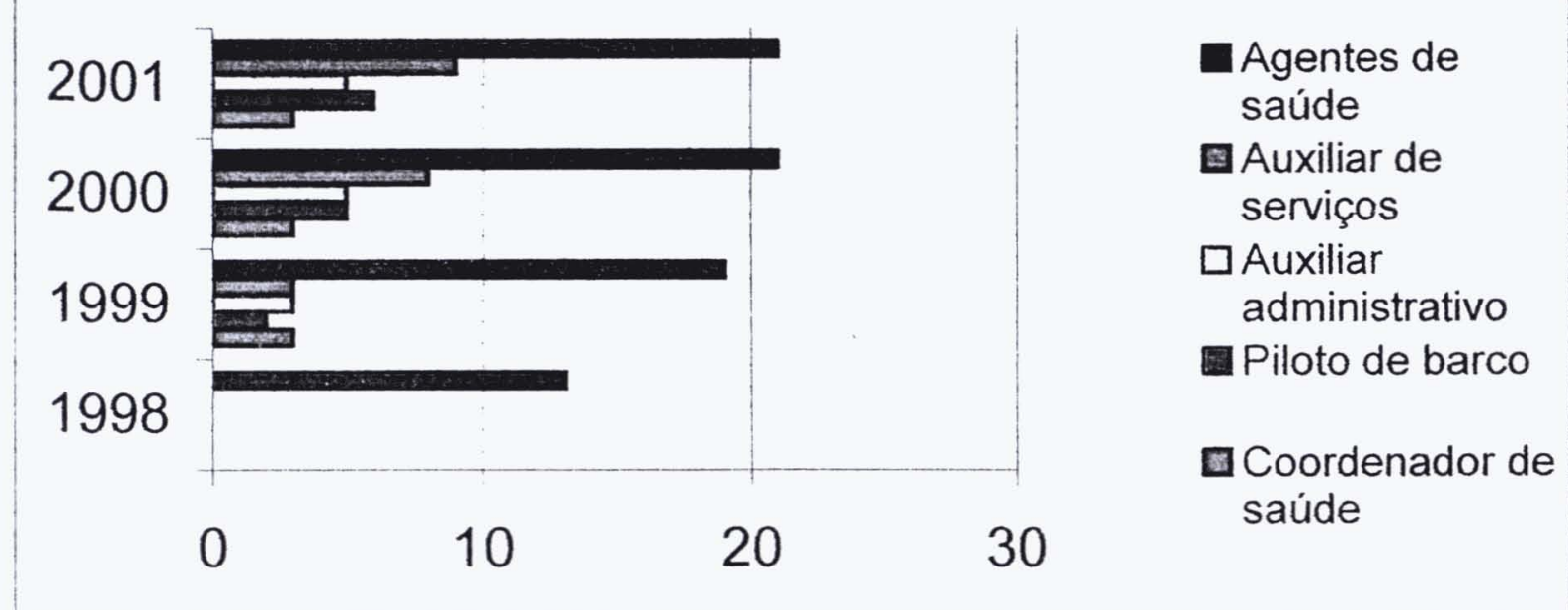




\subsubsection{O trabalho da Supervisão}

A supervisão é uma rara oportunidade de perceber o lócus de aprendizagem dos alunos e o contexto sócio-cultural da formação.

Trata-se de uma expressiva dimensão do trabalho educativo no que tange as suas articulações com a realidade do trabalho e tem por objetivo desencadear e manter atuais as relações entre o ensino e serviço, em seu conteúdo crítico e dialógico.

Singularidades neste processo de acompanhamento do trabalho com enfoque educativo que residem na articulação das dimensões do saber, da produção de serviços de saúde, promoção da saúde e valorização da cultura local. São considerados lugares e oportunidades de aprendizagem: as aldeias, postos indígenas, cidades, viagens e visitas de profissionais. É na supervisão que se exercita a flexibilidade e complementaridade do trabalho médico, entre a medicina ocidental e medicina tradicional indígena, a tomada de decisão e se conhecem e concebem momentos pedagógicos informais, como reuniões e conversas.

Os depoimentos que se seguem foram colhidos em momentos de supervisão. Parecem ser momentos de desabafo, questionamentos e elucidação de conflitos e tensões vividos no cotidiano do trabalho.

Sendo o trabalho o princípio pedagógico da formação, muitos elementos orientadores do processo educativo e da própria organização do trabalho emergem no cotidiano.

"Antes do curso de auxiliar não tinha limite, todo mundo medicava $e$ não tinha padronização, agora faz melhor é olhar, examinar, ver o ouvido, ainda falta muita supervisão"

Puran Kaiabi, AEI, 2000.

"Sobre a organização da UBS eu quero explicar o seguinte: se o AIS não faz é porque não gostou do que foi pedido, ou não entendeu o que foi explicado".

Maiowê Kaiabi, AEI, 2000 
" Até agora o que eu mais gosto é de assistir o trabalho. Ontem Lavínia deu na minha mão para fazer o trabalho, eu não gosto de fazer direto, mas eu tenho que fazer aqui e vocês vão assistir dar injeção, furar abcesso, fazer exame físico. O médico não ensina direito, só no doente ele mostra, a enfermeira que sabe ensinar mostra no posto, na farmácia, no papel, no medicamento.Só pode pegar 2 de cada vez no posto, é pequeno e o doente não gosta".

Yanahim Waurá, AEI, 2000

"Quem vai se mexer e trabalhar, ficar perto e ai pegar amizade, eles nunca reclamam de quem pegou amizade".

Aiato Kukuro, AIS, 2000

"Caraiba pega amigo no trabalho, trabalha junto e fica mais junto que família, nós não, somos parentes, vivemos juntos e ai trabalhamos do jeito do branco e brigamos. Nós não podemos falar mal dos colegas de trabalho.

Sempre teve escola paulista aqui, era o reitor que dava, agora é o distrito e o distrito é nosso, o dinheiro é nosso. Antes ninguém queria trabalhar, porque não tinha dinheiro nem instrutoras".

Yanahim Waurá, AEI, 2000

O Distrito é exemplo mas nossos chefes são grandes e fortes, porisso todo mundo fala do Xingu. Onde vai juntar o distrito com os nossos chefes?

Anuiá Yawalapiti, AIS, 2000

Dentre os supervisores, destacamos as enfermeiras, médicos e também os auxiliares de enfermagem e AIS antigos; outros profissionais indígenas como pilotos de barco, cozinheiros e lideranças que no contexto das viagens de supervisão se inserem nas equipes de trabalho $e$ desenvolvem um olhar educativo sobre o mesmo. Participar das equipes parece reforçar em todos elementos a sensação de pertencimento e institucionalização enquanto profissional de saúde.

"O pessoal pensa que entender português é entender o trabalho Entender a língua é só um começo"

Yacutá Trumai, AIS, 2000

"Eu sempre venho gostando dos cursos e das viagens, tentando aprender e junto enfrentar o trabalho"

Poikô Kaiabi, AIE, 2000 
"Em 12 anos de trabalho, eu treinei bem escrever, examinar $e$ perguntar sempre. Ajuda muito a comunicação. Supervisão à distância nunca deu certo."

Puran Kaiabi, AIE, 2000

"Ninguém nasceu para aprender tudo de hoje para amanhã.

Maiowê Kaiabi, AIE, 2000

Apareceu muita coisa nova agora. Eu estou sempre na aldeia pescando, dançando, lutando e trabalhando. Mas ainda sou pequeninho para os chefes.

Taliko Kuikuro, AIE,2000

O conteúdo simbólico também aparece na aprendizagem:

"Então a professora teve sonho... Foi sonho ruim ou sonho bom? Falo para você assim, sonho que deu para aprender ou não? Iambrá Txicão, piloto de barco, 1999.

\subsection{A Proposta de Formação da FUNASA/Ministério da Saúde}

As possibilidades educacionais trazidas pela LDBE/96 e Decreto Lei 2208/98 passaram a apontar a construção de trajetórias de profissionalização flexíveis, consoantes com as diretrizes atuais da educação profissional. Foi constituido na FUNASA um grupo de trabalho, composto por profissionais com experiência em formação de AIS provenientes de todo país, que passou a discutir e elaborar referenciais de formação dos AIS a partir do seu perfil de competências, como demonstra o Quadro 5. 
QUADRO 5 - Competências elaboradas pelo Grupo de Trabalho do DEOPE/COSAI, 1999.

\begin{tabular}{|l|l|}
\hline Competência 1 & $\begin{array}{l}\text { Elaborar seu plano de trabalho com base na identificação } \\
\text { das necessidades relacionadas ao processo saúde/doença, } \\
\text { de acordo com o contexto de sua atuação }\end{array}$ \\
\hline Competência 2 & $\begin{array}{l}\text { Prestar cuidados básicos de recuperação e reabilitação, } \\
\text { indicados para as diferentes fases do ciclo da vida }\end{array}$ \\
\hline Competência 3 & $\begin{array}{l}\text { Realizar açães de promoção da saúde, que resultem na } \\
\text { melhoria da qualidade de vida, utilizando os recursos dos } \\
\text { serviços e práticas existentes, de forma articulada com } \\
\text { recursos de outros setores }\end{array}$ \\
\hline Competência 4 & $\begin{array}{l}\text { Empreender ações básicas de atenção a saúde individual, } \\
\text { familiar e coletiva, com ênfase na prevenção e controle das } \\
\text { enfermidades transmissiveis e no controle do meio ambiente }\end{array}$ \\
\hline Competência 5 & $\begin{array}{l}\text { Gerenciar seu trabalho, atuando individualmente ou em } \\
\text { equipe, acompanhando, avaliando e reorientando o processo } \\
\text { de prestação de cuidados sob sua responsabilidade }\end{array}$ \\
\hline Competência 6 & $\begin{array}{l}\text { Conhecer a política nacional de saúde e os aspectos } \\
\text { pertinentes a saúde indígena }\end{array}$ \\
\hline
\end{tabular}

O grupo discutiu amplamente o perfil profissional, quanto à idade, residência na comunidade, domínio do português, e experiência de trabalho, à semelhança das experiências já descritas. Os critérios populacionais para inserção dos AIS se mostraram polêmicos. Havia uma tendência a se reproduzir os parâmetros vigentes do PACS, no que diz respeito a proporção de um AIS por 200 habitantes, ou um por comunidade, e de um enfermeiro supervisor para cada 15 agentes de saúde. Esses parâmetros, ainda que de difícil adequação trouxeram novidade para a discussão da formação voltada para a lógica organizativa dos serviços e programas de saúde, e não apenas para a manutenção de padrões mínimos de assistência nas comunidades. 
No entanto, a diversidade de situações e realidades deixa claro que o uso de indicadores e proporções padronizados sem considerar o contexto étnico e cultural pode comprometer todo o processo.

O grupo de trabalho pela primeira vez elaborou uma descrição do perfil do instrutor/supervisor: estar lotado na equipe do distrito; ter disponibilidade para desenvolver as atividades nas comunidades indígenas; conhecer e respeitar os aspectos culturais dos grupos indígenas com os quais vai atuar; não ter outro vínculo empregatício; ser profissional de nível médio ou superior; ter facilidade para o trabalho em equipe, bom relacionamento com as comunidades indígenas e com os agentes de saúde. Não houve dúvidas quanto a necessidade do supervisor fazer parte do processo de trabalho de cada distrito, uma situação pouco vivenciada nos treinamentos anteriores (FUNASA 1999).

Discutiu-se amplamente se a atuação dos AIS deveria estar reportada à promoção da saúde em detrimento da intervenção no processo saúde/doença, e se sua inserção deveria voltar-se para a comunidade ou para as instituições (SILVA JA 2001). A polêmica que tem permeado o trabalho dos ACS guarda semelhanças com o trabalho de saúde indígena $e$ pode ser agravada por mais uma dificuldade: da expressão na língua portuguesa, no sentido mais restrito, e da incompetência comunicativa entre as comunidades, culturas e instituições, no sentido mais amplo.

Aspectos metodológicos e de organização curricular diferenciada também foram destacados no grupo. O material preparado pela FUNASA pretende atender os princípios da flexibilidade e progressividade do ensino técnico e orientar a articulação com as escolas técnicas de saúde do SUS, possivelmente as parceiras ideais no quesito da legalidade e legitimidade dos processos.

A fragilidade das práticas de ensino no contexto dos distritos, decorrentes das dificuldades logísticas, falta de pessoal capacitado e 
compreensão dos gestores sobre o processo de formação, além das inúmeras dificuldades de articulação entre as instituições formadoras, foram mencionadas por todos os participantes, de todo país, evidenciando um paradoxo: ao mesmo tempo que a formação de recursos humanos é considerada prioridade política na área, a insuficiência de instrumentos de trabalho e condições para o seu desenvolvimento têm prejudicado severamente sua continuidade (FUNASA 2000).

\subsection{Elementos para avaliação dos programas de formação}

As políticas diferenciadas e os programas de acesso às escolas de saúde para estudantes provenientes de minorias étnicas iniciaram-se nos USA e Canadá na década de 70.

As primeiras avaliações já demonstravam as dificuldades em desenvolver parâmetros de avaliação desses programas, pela falta de termos de comparação e de variáveis relevantes (WEPPNER e col.1999).

Os custos elevados, altas taxas de evasão e a longa duração dos processos são os problemas mais citados nas publicações. Para EPPS e col., (1993) o acompanhamento individual dos alunos e o uso de variáveis qualitativas na mensuração dos resultados podem ser um diferencial importante. Esses autores recomendam a realização de estudos longitudinais de acompanhamento e a apreciação sistematizadas das comunidades de origem sobre os resultados alcançados. No Brasil esses estudos de impacto qualitativo praticamente inexistem.

Para a FUNASA o processo de formação implantado requer um acompanhamento sistemático do desenvolvimento dos cursos, com vistas a institucionalização de um processo avaliativo, que deve centrar-se no desempenho em serviço dos AIS e utilizar instrumentos de avaliação de 
processo, produto e da dimensão qualitativa da aprendizagem, sendo essa responsabilidade atribuída às enfermeiras de cada distrito (FUNASA 2001).

Propõe-se a seguinte hierarquia avaliativa:

- O enfermeiro do pólo base avalia o AIS

- Os técnicos do DISEI avaliam o processo de formação

- A escola técnica faz o acompanhamento pedagógico do processo, com vistas à legitimação

Outro aspecto pouco explorado na avaliação desses programas seria o do custo dos processos de formação, considerando sua abrangência e impacto imediato na atenção à saúde, organização dos serviços locais e como parte da educação continuada de toda a equipe (Anexo 7).

\section{Experiência de avaliação no Xingu}

Na realidade dos cursos de formação de agentes indígenas de saúde do Xingu, a avaliação formal passou a ser organizada em 1996. Desde então, vem sendo desenvolvido um enfoque processual da avaliação, e o resultado verificado por desempenhos, no sentido mais objetivo e voltado à dimensão técnica do trabalho. O componente subjetivo é valorado no sentido mais amplo e coletivo e registrado em impressos próprios. Cada aluno possui um prontuário escolar, que busca retratar sua trajetória de formação.

A utilização de instrumentos de avaliação organizados em fichas de desempenho, listagens e check lists, demonstrou ser eficaz nos seguintes aspectos:

- orientam e organizam o trabalho em equipe e a divisão de trabalho; 
- facilitam a percepção do movimento das sucessivas aproximações ao objeto da aprendizagem;

- sistematizam as experiências através do uso de instrumentos como a ficha de observações, ficha de desempenho, atividades livres de desenhos, croquis e descrições, ficha de registro de fatos relevantes para a aprendizagem e

- formalizam o momento de avaliação, contemplando discursos e rituais de aprendizagem, com participação de toda a comunidade (Anexos 8 , 9 e 12).

Uma característica comum nas falas dos AIS sobre avaliação refere-se ao seu caráter projetivo numa construção espontânea do futuro e da continuidade do processo de elaboração e retenção do conhecimento em família. São comuns menções do tipo "o AIS que eu quero ser"

ou "como vai ficar o nosso trabalho daqui dois ou três anos."

Trazem uma dimensão pró-ativa de avaliação, na qual o saber ultrapassa os limites do individuo, como se observa nas falas abaixo:

"Quero ser um AIS conhecido do mundo" Paulo Kamaiurá, AIS, 2000

"Ano de 2005 vou mudar de aldeia e parar de trabalhar. Mas já vou ter ensinado meu filho e ele continua"

Yawot Kaiabi, AEI, 2001

"Agora já me formei, estou ficando velho. Vou pegar o COREN e me aposentar, vou passar tudo para o meu filho"

Taliko Kuikuro, AEI, 2000

Essas falas demonstram que os sistemas indigenas de conhecimento são muito mais complexos do que aparentam em uma primeira aproximação e integram-se ao tempo futuro, famílias e comunidades. 
Na dimensão qualitativa do processo, faz-se necessário desvelar as diversas premissas que os orientam. O movimento do aprendizado, expresso na avaliação, articula vários saberes e vários mundos.

Quanto ao aspecto do financiamento, os parceiros se alternaram de acordo com as agências financiadoras do Projeto Xingu como um todo: FUNAI, o Programa das Nações Unidas- Prodeagro /Governo do Mato Grosso e FUNASA. A formação sempre esteve acoplada ao processo de trabalho e porisso os custos totais foram minimizados. $O$ cálculo do custo médio por aluno nos cursos seria relevante para essa avaliação, mas não foi possivel concluí-lo para esta pesquisa. 


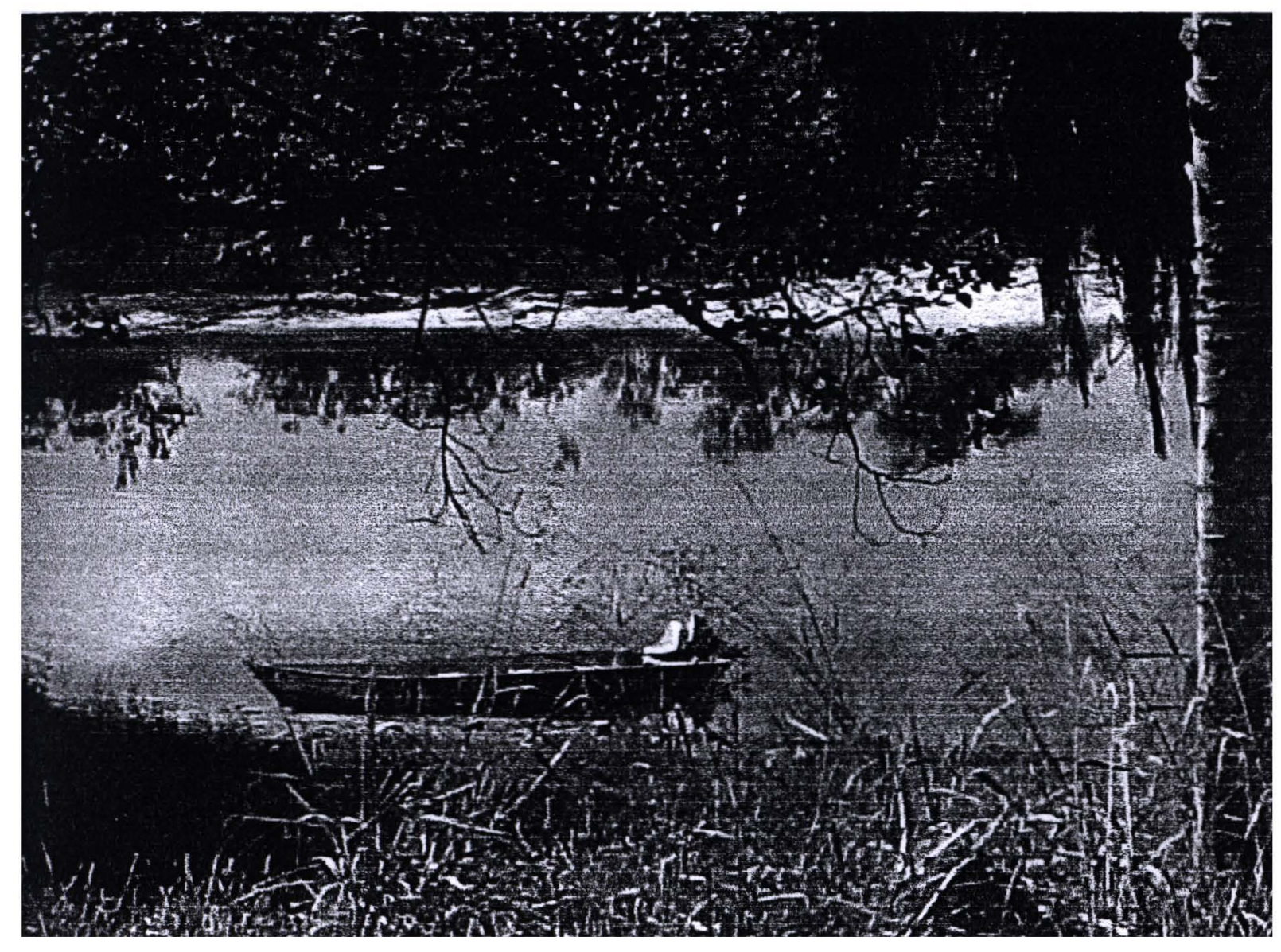




\section{ANÁLISES}

\subsection{Dos enfoques de análise}

A discussão proposta está mediatizada por um enfoque relacional.

A opção de lançar diferentes olhares sobre um objeto complexo (MORIN 1996) vem da intenção de composição de uma análise multideterminada e abrangente. Parece-nos que o caminho da pesquisa pode ser traduzido como um esforço de sistematização de uma trajetória de formação e trabalho dos agentes indígenas de saúde. Seria um primeiro passo para a reflexão dessa prática e estabelecimento de tramas teóricas sobre um objeto complexo, que é também sujeito (SANTOS 2001).

Os enfoques educativos, antropológicos e políticos estão organizados por conceitos norteadores. São eles: a interdisciplinaridade, cidadania, interculturalidade e participação.

Nas especificidades da análise, encontramos na educação os referenciais teórico-metodológicos que embasam as novas experiências pedagógicas multiculturais, os conceitos da legislação de ensino e princípios da educação profissional em saúde.

$\mathrm{Na}$ antropologia, houve a preocupação de se pensar antropológicamente os processos e situações educacionais cujos agentes principais sejam indígenas, destacando-se os conceitos de etnoconhecimento, fronteira cultural, processo civilizatório e diálogo intercultural.

$\mathrm{Na}$ política, numa perspectiva primeira do estudo, os marcos conceituais do SUS seriam constitutivos da análise específica, com destaque para a eqüidade, participação e universalização. No decorrer do trabalho, 
ganhou vulto a institucionalização, seja pelas principais agências do Governo, como a FUNAI, FUNASA e Ministério da Saúde e sua caracterização jurídica frente aos modelos da Reforma do Estado, seja a discussão dos conflitos emergentes da institucionalização do agente indígena de saúde enquanto integrante, e portanto, um "quase funcionário" do governo no âmbito dos DISEI. A interlocução administrativa dentro da burocracia pública também necessitou ser avaliada na composição dos modelos de saúde pública. A emergência do paradigma solidarista das políticas sociais veio a se estabelecer como um marco explicativo para o trabalho como um todo.

O elevado número e abrangência dos conceitos e referências demonstram a complexidade do objeto.

Em alguns momentos, de modo didático, foi possivel estabelecer categorias narrativas para os sujeitos, espaços e objetos da análise.

Há muito que se pensar sobre o tema, sendo essa uma primeira exploração interdisciplinar, na perspectiva de construção de um novo conhecimento interétnico e intercultural para a área da saúde.

\subsection{Enfoque da educação}

"Xingu é grande escola para todos vocês, agentes de saúde, médicos e enfermeiras da Escola Paulista. Escola de vida, de saber doença, de consertar o trabalho".

Aritana Yawalapiti, cacique, 1998.

Conceitos norteadores: interdisciplinaridade, interculturalidade, multiculturalidade, cidadania indígena, princípio pedagógico do trabalho, educação profissional em saúde.

O enfoque desta análise pretende perpassar os aspectos legais da educação fundamental e profissional no que tange à aplicabilidade dos seus 
princípios; problematizar algumas peculiaridades e generalidades dos processos de formação de AIS enquanto uma experiência pedagógica e aproxima-la do universo da educação profissional no âmbito do SUS.

Há dificuldades em se percorrer fragmentos de textos e interpretar gestos de trabalho. O exercício da análise foi mediado por conceitos norteadores e categorias narrativas facilitadoras. Estamos mantendo as falas dos sujeitos, a fim de exemplificar as situações analisadas.

Inicialmente, consideramos a necessidade de repensar a educação como um sistema de idéias, práticas e saberes presentes nas dimensões culturais, legais e institucionais das sociedades.

Ao longo de sua história, as sociedades indígenas vêm elaborando complexos sistemas de pensamento e modos próprios de produzir e armazenar seus conhecimentos sobre o mundo, o homem e o sobrenatural. (VEIGA e SALANOVA, 2001).

Observar, experimentar, estabelecer relações de causalidade, formular princípios e métodos foram alguns mecanismos que possibilitaram à esses povos o acúmulo de conhecimentos sobre a natureza, a vida social e os mistérios da existência humana. Consideradas culturas ágrafas, por não possuirem escrita alfabética, estas sociedades tradicionalmente perpetuam os conhecimentos através da oralidade, comunicando a herança cultural de geração em geração (MINISTÉRIO DA EDUCAÇÃO 1999).

$\mathrm{O}$ ato de aprender é coletivo e impregnado de magia. As concepções de educação expressas pelos índios são bastante peculiares:

"O indio era muito estudado, se virava, se virava em outros animais". Liderança Krahô, no filme Krahô, 1992

"Não deixem de usar flechas, aprendam com os velhos. É o conselho que sempre dou aos jovens."

Liderança Waiãpi, no filme Espírito da TV, 1990 
"Para aprender é preciso sofrer; tem que gostar para aprender; $e$ depois ir ficando grande, ser profissional é muito grande, é muito bom. Yefuká Kaiabi, AEI e cacique, do Xingu, 1999.

Nas culturas hegemônicas, predomina a desinformação, estereotipia e estigmatização sobre os sistemas de ensino contra - hegemônicos, como se eles sequer existissem.

A experiência escolar veio somar-se aos processos educativos próprios das sociedades indígenas, num movimento de dominação, negação de identidade, integração e homogenização cultural. A escola indígena historicamente foi formada pela imposição de modelos educacionais, através da dominação, em detrimento dos paradigmas de pluralismo cultural e busca de identidades étnicas (SILVA AL 2001).

A visão acadêmica igualitária e romântica que emergiu nos anos 70 não foi suficiente para modificar essa percepção nem as práticas educativas voltadas para os povos indígenas.

Esta situação vem sendo revertida muito recentemente. A Constituição de 1988 restitui as pregorrativas do ser índio, assegurando o ensino da língua materna (art. 210 da Constituição e art. 78 da LDB 9394/96).

As escolas indígenas, constituídas através do Decreto 26/91 como modalidade de educação diferenciada, estão em franca expansão no país. (MINISTÉRIO DA EDUCAÇÃO, 1999).

Em 1998, estimava-se a existência de 1500 escolas em áreas indígenas, atendendo uma população de 70 mil alunos, com 2900 professores sendo 2 mil índios (VEIGA e SALANOVA, 2001).

No Xingu o processo de educação escolar foi iniciado nos anos 60 coma a alfabetização dos índios por Maria da Penha Villas Boas e continuado 
por Marina Villas Boas, que auxiliavam o preparo dos "secretários" de Orlando Villas Boas.

As primeiras escolas do Xingu se organizaram em 1976, e os cursos foram sendo interrompidos várias vezes ao longo dos anos. Apesar das dificuldades, os índios sempre explicitaram que a educação era uma forma instrumental de convivio com a sociedade não indígena.

Nos anos 80 , paralelamente a intensificação da educação escolar no PIX, o início dos cursos de profissionalização motivou muitos jovens a sair da área para estudar em cidades como Brasília e Goiânia, enfrentando enormes dificuldades de aprendizagem e adaptação.

A experiência sofrida dos alunos indígenas nas escolas públicas demonstra a impermeabilidade do sistema escolar à diversidade cultural (FISHMANN 1996). Para ORIÁ (1998) é preciso que o sistema escolar se aproprie da diversidade cultural como objeto curricular no processo de ensino. Mais do que um lócus de formação da cidadania, a escola pode valorizar elementos da nossa realidade cultural.

Desde o início do século, com o movimento modernista, há uma forte aproximação dos educadores da chamada corrente nacionalista com os modos de ensino-aprendizagem indígenas, que vêm sendo redescoberto nos últimos anos (FREITAS 2001).

A despeito da história degradante da escravidão indígena no Brasil, desde tempos remotos existem pálidas impressões de reconhecimento da inteligência pragmática dos índios, detentores dos conhecimentos e meios apropriados para uma fixação humana em bases duradouras no ambiente tropical (ALMEIDA 1997). O colonizador europeu procurou enfatizar a negação da vocação indígena para o trabalho, para justificar a preguiça, rebeldia e escravidão. 
O trabalho clássico realizado no campo da historiografia por BUARQUE DE HOLLANDA, em Caminhos e Fronteiras 1994, foi um dos primeiros a demonstrar que o nativo era portador de um conhecimento sobre o meio que extrapolava a rusticidade, oferecendo ao homem novo um convívio marcado pela imagem de fronteira. Fronteira, diga-se logo, em quase tudo: hábitos, sentimentos, técnicas, línguas, alimentos, religiosidade, sexualidade (BUARQUE DE HOLLANDA 1994 p. 76) Percebeu que a vida em comum exige estratégia. Notou a qualidade dos sistemas para aferição da hora e dos roteiros já trilhados; a acuidade de perceber/sentir o meio era um dado que proporcionava ao nativo a posse de um capital intelectual essencial que ao homem que chegava. Ao tomar a habilidade indígena, preservada nos grupos sertanejos, capaz de elaborar técnicas e solucionar problemas cotidianos o autor conclui que muitas vezes o homem menos culto e preparado era o intruso.

Buarque enfatizou que o índio não vivia, mas convivia, e isso fazia toda a diferença (FREITAS, 2001).

Em fins do século XIX, com a emergência da educação e pedagogia modernas os estudiosos começam a perceber as diferenças entre os modos de aprender ocidental e dos povos indígenas. Entretanto, o referencial de compreensão era estabelecido a partir da cultura ocidental.

LANGDON (1996) estudando a transmissão do conhecimento e o trajeto de aprendizagem na iniciação xamânica, destaca o papel do cotidiano e das relações familiares no processo.

São vários os mestres; os mestres são os parentes e a auto-iniciação e auto - aprendizagem são valorizadas. Citando Da Matta, enfatiza a necessidade de intercâmbio igualitário de experiências humanas. Para a autora, é perigoso caracterizar os sistemas médicos ocidental e indígena em 
campos opostos. Na prática, os índios seguem um processo terapêutico não muito distinto do nosso (LANGDON 2000 p.114).

O desafio de compreender diferentes modos de pensar e aprender em situação de diversidade moveu o trabalho meticuloso do médico Jean Itard, (BANKS-LEITE e GALVÃO, 2000) realizado há duzentos anos, com um menino selvagem encontrado em uma floresta na França, que ficou conhecido como o selvagem do Aveyron. Contrariando o seu mestre Pinel, o jovem médico Itard acreditou na possibilidade de educar o garoto. Seus estudos, publicados entre 1801 e 1806 permanecem atuais no que tange à instigante problematização das experiências pedagógicas em contextos de diversidade cultural.

Talvez Itard tenha exercitado um dos primeiros olhares críticos sobre os fundamentos históricos da civilização moderna, quando a exaltação do conhecimento científico e a confiança na capacidade do homem conhecer a natureza eram idéias centrais. A figura do selvagem exercia uma fascinação contraditória que mobilizava filósofos, cientistas e cidadãos comuns.

Estudos recentes nessa perspectiva, vêm valorizando o lugar das interações sociais e das emoções na educação diferenciada (GALVÃo e DANTAS 2000).

As concepções de sujeito e de linguagem, a relação entre natureza, cultura/civilização e seus reflexos na prática pedagógica, tais como, organização escolar, composição de currículos, métodos e material pedagógico têm suscitado inúmeros debates. Tudo indica que essa interação está apenas começando, no campo das idéias. Faltam instrumentais práticos que a efetivem. 


\section{Interfaces entre a educação, saúde e ensino profissional}

A área de higiene e saúde pública no início do século $X X$ emergiu no contexto positivista como uma ramificação da racionalidade médica, responsável pela dimensão social. Ensinar a saúde para as populações menos favorecidas foi um caminho natural para os médicos higienistas. Esta dimensão foi levada e permanece impregnada nas práticas da educação em saúde, inclusive na área indígena e no desenvolvimento das atividades educativas nas comunidades. Sua eficácia é bastante questionável.

A oposição à esse tipo de educação surgiu no pais a partir do final da década de 50, com vários movimentos educativos voltados para as camadas populares, tendo em comum o desejo de construção de uma sociedade mais justa e democrática. A expressão educação popular ficou conhecida na área.

A publicação do livro "Pedagogia do Oprimido", de Paulo Freire, em 1968 posicionou a educação como instrumento de conscientização, libertação e transformação.

"Ninguém educa ninguém, nem ninguém educa a si mesmo: os homens se educam entre si, mediatizados pelo mundo". Era a idéia nascente do respeito pelo saber do outro, de uma construção conjunta do conhecimento e da realidade do sujeito.

As experiências de educação popular vieram integrando-se à área da saúde, através de movimentos alternativos de luta contra a ditadura. A educação "saiu" da escola e atingiu o mundo do trabalho.

A inseparabilidade das ações de promoção, prevenção, assistência, planejamento e unificação de saberes permite pensar concretamente a perspectiva da integralidade, um dos princípios básicos do SUS. 
No campo da educação profissional, essas idéias compreendem que o preparo para o trabalho em uma condição de sobrevivência cultural requer o compartilhamento de saberes. Para Carvalho e col.(2001) é preciso desenvolver uma metodologia de ensino que considere a experiência cotidiana dos atores envolvidos e tenha por finalidade a conquista de maior poder nas relações sociais que influenciam a qualidade de vida.

Os profissionais devem reconhecer o outro como sujeito histórico e utilizar o diálogo como prática de relacionamento, tendo prazer de celebrar cada momento educativo. Destacamos, a título de exemplo, algumas falas sobre educação em saúde elaborada pelos AIS nas atividades educativas desenvolvidas nas aldeias, verdadeiros momentos de celebração e festa:

"Olá. Meu nome é Cid Moreira, minha filha, eu vou trazer presentinho que vai deixar você feliz, eu vou ensinar você a ser feliz, vem aqui (na encenação de um teatro educativo)".

Tamariko Juruna, AIS, 2000

"Vamos fazer pequena reunião falar de doença, não só, falar de coisas boas do branco para melhorar a saúde do índio. Tem filme, tem festa." Preayup Kaiabi. AIS, 2000

"O agente de saúde pode fazer reunião com a comunidade todo fim de tarde para explicar, orientar, explicar como pega aids e como não pega. Tem que ser no final da tarde".

Yanahim Waurá, AIS, 2000

Para ARROYO (2001) educar é trabalhar com a totalidade das dimensões do sujeito, e não apenas aspectos comportamentais, ou de habilitação para o trabalho. Deve-se partir do reconhecimento do povo como sujeito de sua própria cultura, enquanto valores estéticos. Por meio dessa ritualização ele busca a beleza.

"Você quer saber mesmo porque eu uso a mamadeira? Porque é bonito. Vocês tem que aprender a trazer coisas bonitas para o nosso povo, a saúde é bonita, não é só palavra."

Mulher Ikpeng, 2000 
Interessa-nos inserir o campo da educação formal e profissional em contextos de diversidade cultural. A mudança da conotação de trabalho difícil e exótico nessa área vem se dando lentamente. A superação se dá na medida em que ocorre uma maior atenção ao ambiente cultural e a explicitação da disposição de diálogo entre diferentes conhecimentos e seus produtores de saberes.

O caminho percorrido na experiência de trabalho do Xingu foi marcado por dificuldades e avanços na organização de conceitos e no processo de ensinar e aprender como um todo:

\section{Expressões do aprender:}

"Foi muito duro, eu apanhei muito no curso, mas agora estou entendendo coisas novas"

Kanawayuri Kamayura, AIS, 1998

"Foi difícil, minha cabeça dói, mas agora eu estou sabendo porque as doenças aparecem"

Tamarikô Juruna, AIS, 1999

"O mais importante é entender como seguir o trabalho, esse é o motivo do estudo".

Maiowê Kaiabi, AIS, 1998

\section{Necessidade de formalização do processo}

"Eu já estava pensando comigo se nunca vai ter prova, não está direito, como vão saber tudo que a gente está fazendo, como conseguir o papel do certificado, quem vai mostrar o que a gente está fazendo aqui no Xingu?"

Tymain Kaiabi, AIS, 1998

\section{Manifestações da construção de conceitos:}

"Estou entendendo assim. Existe uma familia de antibióticos. O mais velho é o vovô benzetacil, ele tem muita experiência, acerta onde está 
a doença. Mas tá cansado então o seu neto, o amoxil, vem correndo, nem precisa da injeção, entra pela boca e trabalha logo, mas ninguém sabe direito o que vai acontecer lá. É como menino quando entra na mata para caçar".

Tymain Kaiabi, AIS, 1998

"Está aqui a dona cefaléia, quer dizer, ela tem dor de cabeça. Eu vou mandar ela embora, com repouso e dipirona".

Ayguré Txicão, AIS, 1998

"Se uma pessoa está fraca, doente, ela está quente. Tem o calor, tem a febre...

Então sinais vitais é isso, ver se está quente, se tem a temperatura... Quando junta essas coisas para o médico é a informação clínica"

Taliko Kuikuro, AIS, 2000

"Como é seu nome? Larvinha? Lavinia? Larvinha de marimbondo ..."

Tamarikô Juruna, AIS, 1997

"A Aids tinha 18 anos de idade, para ele vir ao mundo da terra ele teve que ficar 2.859.399186 meses para nascer. A mãe dele é o sangue, 0 pai dele é a transmissão: Esse é o conceito que eu entendi".

Ayumã Kamaiurá, AIS, 1997

Timidamente, a língua materna vai se manifestando no contexto da sala de aula gerando novos conhecimentos e explicitando conflitos:

"Quero falar desse vírus, dessa doença de aids. Quero mostrar o filme, itsarreke-ni?" (entenderam?)

Ayato Kuikuro, AIS, 2000

"Entende assim: iamimu - em cima; iwyripe - em baixo. A sabedoria mora em cima e em baixo. Mora onde ela quiser, professora...

Ayguré Txicão, AEI, 2001

"Aqui é minha aldeia. É minha sala de aula enquanto não vou no curso".

Marité Ikpeng, 2001

"No começo tudo era mais fácil, eu não me preocupava em dar remédio, todos se sentiam poderosos e felizes. Hoje estou preocupado com essa responsabilidade, a dose certa do medicamento, a hora certa de encaminhar o doente".

Poikô Kaibi, AEI, 2001 
"O trabalho é dificil, é melhor treinar no posto, tem mais coisa para ver. O professor (da aldeia) é Paraguai demais. Quem trabalha há mais tempo tem que dar a vez".

Taravi Kaiabi, AIS, 2001

Talvez pela proximidade com a área de educação, os AIS começam a se interessar pelo português. Anotam palavras que não entendem, perguntam e depois de algum tempo tentam construir palavras novas.

"Tenho uma pergunta muito grande de saúde: o que é solicito? Solicito uma hélice"

Farato Matipu, AIS, 2001

Além do aprendizado com a equipe, os alunos procuram aprender com os AIS mais antigos, utilizando a metodologia problematizadora.

São notáveis os avanços na apropriação construtiva de conhecimentos, no dialógo, participação, ação comunicativa pela oralidade, produção de materiais educativos não tradicionais como filmes, maquetes e desenhos e artesanatos relativos à saúde e a incorporação da prática avaliativa no cotidiano, de maneira processual e contínua.

Os próprios AIS sugeriram uma gradação dos desempenhos técnicos, criando o momento do saber "um pouquinho", intermediário entre o saber tudo e não saber nada, em posição ao parâmetro formal de desempenho estabelecido pelo sistema formador, nas variáveis fixas sim e não (Anexos 14 e 16).

Essas experiências indicam a necessidade de desenvolver e utilizar mais instrumentos educativos no cotidiano, para registro dos AIS e que sejam facilitadores do processo de supervisão e da aprendizagem: desenhos, caderno de dúvidas, músicas de fita e CDs para o aprendizado do português e a apropriação crítica dos conhecimentos das outras sociedades através dos filmes, viagens e festas. 


\section{Aspectos legais sobre e o ensino fundamental e a educação profissional}

A Câmara de Educação Básica do Conselho Nacional de Educação, no processo 23001-00263/98, considera como ponto de partida para o referencial curricular nacional para as escolas indígenas que todos os povos indígenas possuem mecanismos de transmissão de conhecimentos e socialização que independem da instituição escolar. Assim é para a educação profissional. As sociedades indígenas reproduzem-se pela posse coletiva da terra e usufruto comum dos recursos nela existentes; organizam-se a partir da divisão de trabalho por sexo e idade e são regidas por regras, compromissos e relações estabelecidas por parentesco, amizade ou contextos rituais e políticos que tem por base o principio da reciprocidade.

Dos missionários jesuítas aos positivistas do SPI, do ensino catequético ao bilíngüe a tônica foi uma só: negação da diferença e assimilação.

Desde os anos 80 , quando a escola indígena passa a assumir um novo significado, o de garantir acesso aos conhecimentos gerais sem negar a identidade e especificidade cultural dos grupos, a escola começa a praticar a interculturalidade e reconhecer um projeto futuro para os índios, que ultrapasse a sobrevivência.

O Estado coloca-se a função de garantidor da diferença étnica e das manifestações culturais indígenas (art. 231 da Constituição de 1988, op.cit.). Deve proteger a diversidade, fomentar o fortalecimento de diferentes culturas, e instrumentalizar os membros da comunidade para a autogestão dos processos sociais, políticos e econômicos, promovendo a autodeterminação em seus territórios. 
No entanto, o contexto legal favorável está repleto de contradições. A nova LDBE define como um dos princípios norteadores do ensino o pluralismo de idéias e concepções pedagógicas (art. 78 e 79). A Lei incentiva a produção de currículos e programas específicos, neles incluindo conteúdos culturais correspondentes as respectivas comunidades. Os intrumentos de organização e gerenciamento escolar continuam pouco flexiveis, como o calendário letivo, diários de classe e sistemas de avaliação.

Em que pese a boa vontade de setores de órgãos governamentais, o quadro geral ainda é permeado por experiências fragmentadas e descontínuas, regionalmente desiguais e desarticuladas. Tal pluralidade de situações dificulta a implementação de uma política nacional. Há necessidade de regularizar juridicamente esses processos, contemplando experiências bem sucedidas, que devem ser tratadas pelas agências de ensino como experiências pedagógicas e adequadas institucionalmente para a implementação de uma política de governo.

A legalização do processo de profissionalização em saúde no Xingu, no quesito da tão propalada flexibilidade e progressividade do ensino evidenciou muitas vezes fragilidades e conflitos. Por exemplo, para obtenção do certificado de ensino fundamental, foi necessário aos alunos a realização de exames de português, matemática, ciências sociais e ciências naturais, nos moldes tradicionais do ensino supletivo.

Não houve condições nem respaldo para busca e estruturação da certificação por competências, possibilidade legalmente reconhecida, que garantiria o ensino fundamental e é mais afinada com o itinerário de aprendizagem dos alunos que nunca haviam freqüentado a escola nem passado por nenhum sistema de avaliação.

Esses embates e seu enfrentamento pelos índios assemelhou-se à uma luta: 
"Porque você ( professora) não confia que a gente vai enfrentar prova? Pode vir essa prova, nós vamos matar ela logo, nós vamos acabar com ela!"

Ayguré Txicão, AIS, 1999.

Sabe-se que enquanto prática social, a educação está em constante mudança. A legislação de ensino atende a necessidade de construir novas alternativas de organização curricular e avaliação comprometidas com o novo sujeito do trabalho e os novos significados do trabalho. Destaca-se o Decreto 2208/97, da Educação Profissional, como norteador dessas alternativas.

O significado da escola nas áreas indígenas seria instrumentalizar o acesso à profissionalização e reelaboração cultural.

A análise educativa aponta para a perspectiva de salto de qualidade na educação geral e educação profissional na área indígena. As recentes pesquisas culturais e de revisitação do pensamento nacionalista vêm indicando que a cultura pode ser desenvolvida por meio de experiências pedagógicas.

A trajetória de profissionalização na saúde vem se ampliando e diversificando com a prática da interdisiciplinaridade e a inclusão de novos conteúdos e dimensões como a arte-educação, educação ambiental e etnomatemática, presentes na formação dos AIS do Xingu.

Compreende-se que o trabalho educativo, como parte do trabalho em saúde tem amplo potencial de formação, legalização e legitimação.

Essas experiências indicam que é preciso contruir um projeto étnico político para a educação profissional indígena, que compreenda o trabalho cotidiano e o extra cotidiano, comporte as contradições entre o pensar e 0 fazer nos limites de espaço, tempo, pessoas e ação (ANGELIS 2001).

A apropriação desse processo no contexto dos DISEI é teoricamente possivel, mas ainda muito frágil. A formação é necessária, mas não suficiente 
para abarcar a dimensão da construção da cidadania indígena e a organização dos serviços de saúde.

Há um grande risco de descolamento entre as práticas de ensinoaprendizagem, devido ao fazer cotidiano sobrecarregado de demandas imediatas dos DISEI, como a assistência direta, vigilância epidemiológica, a administração de recursos.

Dentre os sujeitos que ensinam e aprendem, profissionais, sábios, índios e não índios é preciso abstrair e trocar as experiências e instrumentalizar a ação e a participação, caminhando em direção da educação multicultural (GADOTTI 1996).

A construção de perfis profissionais, dentro de um Projeto etno político para a educação profissional indígena, talvez seja um bom início, seguido da formalização dos processos de formação que integrem os conteúdos do ensino fundamental, como já acontece com a etno-matemática no Xingu. $O$ interconhecimento e trânsito por diferentes saberes resultantes desses diálogos pode referenciar e balizar novas trajetórias profissionais para os povos indígenas.

\subsection{O Enfoque da antropologia}

Conceitos: etnoconhecimento, fronteira, participação, profissionalização, interdisciplinaridade, autonomia, diálogo intercultural,

"É possivel ser indio e ser profissional".

Marlene Ticuna, AIS do Rio Negro, 2001

Pensar antropológicamente os processos e situações educacionais cujos agentes principais sejam indígenas implica na necessidade de aprofundar as relações teóricas e metodológicas entre a antropologia e a 
educação. A possivel contribuição da antropologia na interface dessas áreas seria a possibidade de articulação e diálogo entre o contexto histórico e a ação educativa, capaz de trazer outra racionalidade ao processo como um todo.

A profissionalização de indígenas em diferentes áreas parece situar-se na ampliação das estratégias de sobrevivência para esses povos no mundo globalizado. $O$ posicionamento indígena nesse sentido é claro, e articula o tempo passado ao futuro:

"Antigamente, a arma do índio era arco e flecha, agora é o estudo e a informação"

Cacique Adolfo Timóteo, aldeia guarani do Rio das Silveiras, SP, 2001.

Foi no contexto da globalização que os órgãos internacionais começaram a reconhecer o caráter pluricultural dos Estados. A Convenção OIT 169/89 sobre Povos Indígenas e Tribais de Países Independentes, eliminou o caráter integracionista da Convenção original, reconhecendo que a diversidade étnica e cultural dos povos indígenas deva ser respeitada em todas suas dimensões, incluindo o emprego, educação e saúde, entre outros (LANGDON 2000, UNESCO 1997).

Esta tendência está expressa nos Princípios sobre a Tolerância, aprovados pela UNESCO em 1995 e nas crescentes preocupações com a diminuição da pobreza e desigualdade social entre as minorias étnicas, que vêm se refletindo diferenciadamente nas legislações de cada país (LANGDON 2001; TORRES e RIO, 2001).

Alguns estudos sobre a globalização e 0 avanço sem fronteiras da lógica de produção capitalista levaram os autores a questionar a sobrevivência de grupos étnicos e culturas diferenciadas. Tomando como exemplo os povos da região do UAÇÁ, no norte do Amapá e os Guarani do sudeste, TASSINARI (2001) defende a idéia de que as diferenças culturais e 
étnicas emergem justamente em virtude do contato, e não apesar dele. Reforça seu argumento citando Gupta e Ferguson: (1992)

'a ironia de nossos tempos, talvez, seja que enquanto os locais tornam-se cada vez mais vagos e indeterminados, idéias de lugares distintos culturais e etnicamente tornam-se mais salientes"

A construção dessa diferença que se dá no espaço de contato, no qual as clivagens étnicas são definidas, tem sido denominado por alguns estudiosos sob o tema das "fronteiras", não necessariamente geográficas, mas sociais.

Para HANNERZ (1997), as fronteiras são regiões nas quais uma coisa se transforma gradualmente na outra. Nelas há indistinção, ambiguidade e incertezas.

BARTH (1995) problematizando as fronteiras entre grupos sociais constata que as culturas e sociedades não configuram unidades fechadas, autocontidas, limitadas, mas permitem um fluxo tanto de pessoas, quanto de conhecimentos.

O autor propõe uma noção transitiva de cultura:

"O foco no conhecimento articula a cultura de modo que a torna transitiva na interação entre as pessoas, devido ao seu uso potencial por ambas as partes. Assim, outros modos de representação e outras questões mais dinâmicas vêm a tona quando modelamos a cultura nessas modalidades: variação, posicionamento, prática, troca, reprodução, mudança, criatividade" BARTH (1995 pg. 66) 
Por certo, a reflexão teórica sobre escolas indígenas e distritos de saúde indígenas pode ser beneficiada por esses conceitos.

Compreender as concepções e experiências indígenas sobre educação, trabalho e saúde em diferentes contextos sócio-culturais, significa, antes de mais nada, inseri-las analiticamente em processos múltiplos e singulares.

Para uma análise mais aprofundada parece-nos útil observar as convergências e divergências das experiências de formação e trabalho desenvolvidas para povos indígenas e suas mudanças no sentido interno e externo às comunidades.

No caso do Xingu, há distinções vagas entre o fluxo de conhecimentos e pessoas. As possibilidades de contato, educação e trabalho estão se modificando e ampliando com muita rapidez, em um cenário de muitos conflitos.

Os índios estão construindo e acumulando experiências de trabalho nas áreas de agricultura, meio ambiente, ecoturismo, administração e gestão de associações, além das áreas mais antigas como educação, saúde e apoio operacional. Não deixaram, entretanto, de fazer suas roças, artesanato, festas, caçadas, pescarias e outras atividades tradicionais. Os trabalhos estão se sobrepondo, chocando e acomodando.

No contexto da saúde, os espaços e as relações de trabalho são complexas e conflitantes. Podemos destacar seguintes relações que vêm se estabelecendo no contexto do DISEI Xingu.

Índios que trabalham para o branco - Foi a condição primeira, de ajuda, dos jovens AIS nas equipes médicas. Sua inserção é sempre tímida, silenciosa e subalterna. Há uma forte relação de confiança com a coordenação atual do Projeto Xingu. 
"Eu não sei nada. Fiquei sabendo agora como chama a gente ou agente( de saúde). Tudo difícil, eu vou ajudar o branco trabalhar só olhando"

Piwara Ikpeng, AIS, 1998

" O Douglas é nosso chefe, nosso cacique, ele sempre sabe resolver. Todos nós trabalhamos para ele"

Ayguré Txicão, AEI, 1999

\section{Brancos que trabalham para o indio}

Com a ampliação das equipes de não índios na área, vários conflitos se estabeleceram pela falta de clareza de ambas as partes sobre o significado de estar, e praticamente morar, em uma área indígena. Há uma associação implícita na fala de índios e profissionais da cidade que a condição de estar morando no "mato" deve-se a falta de melhores opções de trabalho.

" Eu não sei não. Quanto mais eu faço, mais eles querem, dão ordens, ficam xingando, mandando mesmo. É muito stress viver na área. " Ceni Oliveira, auxiliar de enfermagem, 2000

"O trabalho é nosso, da saúde. O branco trabalha para nós. Mas o pior do trabalho é a inveja, o ciúmes. Hoje estamos aprendendo muita coisa na área da saúde e educação, que chegou primeiro para nós. $O$ distrito é uma coisa que vai cuidar de nós, mas nem eles sabem o que é isso. Os agentes de saúde contratados estão ficando grandes, a comunidade tem que vigiar isso, para não dar fraqueza na cabeça, eles trabalham para eles e para nós"

"Mairawê Kaiabi, presidente da ATIX, 1999

\section{Índios que trabalham para o índio}

A aproximação ao trabalho de saúde costuma se dar pela curiosidade, indicação de familiares e lideranças, sempre no sentido de ajuda comunitária. 
Esse trabalho vem sendo considerado um espaço privilegiado de interação, aprendizagem e acesso aos benefícios do branco, inclusive da remuneração.

Nos últimos anos, algumas lideranças têm entendido que a profissionalização dos índios caminha no sentido de substituição do trabalho dos brancos, e colocam um papel de mediação política para os AIS.

"Nós que é vamos mexer com o povo, os brancos não vão ficar aqui, quem vai trabalhar para nós são vocês. A linguagem do branco é muito dificil, porisso entre vocês tem que transmitir, quem é Karib transmitir o que é, quem é Aweti e Kamaiurá transmitir o que é, levar isso para frente"

Aritana Yawalapiti, cacique, 1998

"Vim participar do curso porque eu gostei da saúde. Vou saber cuidar das doenças e ajudar a comunidade a ter saúde".

Nikumali Yawalapiti, AIS, 1999

"Eu vim escolhido pelo primo, ele é o chefe da comunidade" Arindi Kuikuro, AIS, 1998

Em muitas situações o trabalho de um AIS de outra etnia não é bem vindo, devido conflitos pré-existentes.

"Eu não aceito vacina dele. Ele não sabe nada e vai matar nós" Liderança Kalapalo, referindo-se a um AIS Waurá, 2001

"Esses doutores são paraguai, não sabem nada esses agentes de saúde"

Liderança Kaiabi, referindo-se a um AIS Suiá, 2000

Os conflitos étnicos, de situação profissional e de divisão de trabalho parecem ser absorvidos lentamente e mediados pelas lideranças e novos profissionais. Existem dúvidas e críticas se a introdução de cargos e salários seria uma prática assimilatória e quais seus possiveis desdobramentos. 
Em um processo de reelaboração cultural, o conceito de mediação parece pertinente para fazer frente à essas novas realidades.

De maneira incipiente, algumas propostas de mediação estão surgindo, como, por exemplo, a criação de sistemas de educação e capacitação para os adultos, possibilidades de pôr em prática os novos conhecimento em benefícios diretos e indiretos nas comunidades, mediante a contratação de indígenas para funções temporárias e articulação do conhecimento ocidental aos conhecimentos e práticas da medicina tradicional na determinação de novas funções.

Muitos AIS e AEI estão se voltando para o conhecimento dos pajés.

Um número expressivo dos novos AIS é filho ou parente próximo de pajés.

"Meu pai era pajé e cacique. Ele mandou eu participar curso. Meu pai já faleceu"

Tadjui Kalapalo, AIS, 2000

"Meu pai é Tovela, meu pai é pajé. Ele mandou eu participar, eu gosto de trabalhar, ele disse que eu posso controlar a febre na comunidade" Kuliuku Matipu, AIS, 2000

"Eu gostei porque o Taliko (AEI) está precisando de ajuda na comunidade. Meu pai mandou, ele é pajé na comunidade Kuikuro" Ayato Kuikuro, AIS, 2000.

É no espaço dos DISEI, na fronteira desses mundos, que a identidade profissional dos AIS e de profissionais não índios vem sendo construída.

Esse parece ser espaço de incompreensões e redefinições identitárias para índios e não índios. Os processos de formação como um todo ainda tendem a contribuir no deslocamento dos focos de poder tradicional dos caciques e pajés, uma situação geradora de grandes conflitos. 
Do ponto de vista educativo e antropológico, é no DISEI que ocorre o acolhimento da complexidade. Nele se manifestam as relações de poder, do grande poder sobre a vida, morte, natureza, o corpo e a saúde. É no distrito sanitário indígena que vem se manifestando o pouco compreendido pensamento ameríndio, no qual a saúde transita pelas relações entre seres humanos, natureza e espíritos (VIVEIROS DE CASTRO, 1996).

Iniciar a compreensão, ainda que palidamente desse pensamento significa acolher nesse espaço de ensino e trabalho as idéias aparentemente contraditórias atribuídas aos fenômenos naturais como por exemplo, a morte. Por um lado elas nunca são casuais, mas sempre provocadas por alguma agressão, como a feitiçaria. Por outro lado é um destino inexorável, resultante de uma desobediência primordial.

O papel dos profissionais frente à estas questões iria muito além da dimensão técnica; compreenderia a tradução do processo saúde doença em diferentes perspectivas, implicaria em um estado de atenção para as manifestações sobre o corpo, a doença e a morte elaborada pelos AIS no seu cotidiano. É evidente que a assessoria antropológica capaz de avançar nessa tradução seria um grande diferencial para o trabalho e formação como um todo (SILVA AL 2001).

Esta breve análise apontou algumas variáveis antropológicas que permeiam o processo ensino aprendizagem no DISEI Xingu. A principal possibilidade de melhor compreender essa complexa realidade parece vir de atitudes e práticas de valorização dos espaços de troca e intercâmbio entre indígenas de diferentes etnias, dentro e fora do Xingu, que se encontrem em variados estágios de aprendizagem e trabalho, juntamente com detentores do conhecimento tradicional e dos novos conhecimentos.

As viagens de supervisão revelam uma condição de tempo que propicia essas aproximações. 
As aldeias do Xingu, principalmente à noite, são um interessante lugar de reflexão. Percebe-se ali a existência de abismos entre os pressupostos teóricos, diretrizes curriculares e formas de execução dos programas de formação, incoerências políticas e administrativas, incertezas pessoais.

Há uma necessidade premente de vivenciar e aperfeiçoar os mecanismos de comunicação e argumentação intercultural, produzindo-se uma comunicação multicultural.

O conceito de eticidade e cidadania, proposto por OLIVEIRA (2000) é pertinente no sentido de propor a construção de uma verdade que seja fruto de negociações, como uma fusão hermenêutica de horizontes.

Quais seriam os novos pensadores, produtores de novos conhecimentos capazes de dar conta dessa realidade tão complexa? Quais seriam os melhores intérpretes e mediadores: os novos profissionais indígenas? velhos sábios mais instrumentalizados? profissionais não índios mais sensiveis e preparados? Qual seria o melhor tempo para essa negociação de verdades?

Eu não entendi nada. O que é isso, o tempo? Cada um de vocês explica de um jeito, das horas do remédio, se vai chover, quando você nasceu. O que é o tempo? Quando eu vou aprender?

Tymain Kaiabi, AIS, 2000

ELIAS (1994), em seu ensaio sobre o tempo, adverte-nos claramente sobre o equívoco de expressões sobre determinar e medir o tempo. A base de recordações para os antigos, não era o tempo, mas os acontecimentos. 0 tempo seria um meio de orientar a elaboração de tarefas sociais mais precisas. E qual a tarefa nesse tempo? O que é preciso fazer para acontecer agora? 
$\mathrm{Na}$ incansável busca da compreensão do outro, o tempo e o diálogo continuam sendo decisivos.

\subsection{Enfoque da política}

Conceitos: equidade, participação, institucionalização, profissionalização, diálogo interétnico e intercultural

O ponto de partida desta análise é a construção da política nacional de saúde para os povos indígenas e suas relações com as determinações legais, que reconhecem aos povos indígenas suas especificidades étnicas e culturais e seus direitos territoriais (FUNASA 2000).

A política insere-se em um esforço de reversão dos quadros de desassistência e falta de acesso à saúde expostos anteriormente e atende grande parte das recomendações das conferências de saúde indígena, consideradas enquanto um espaço legítimo de manifestação do movimento indígena pela saúde. Não aprofundaremos o processo de conflito com órgão indigenista no período estudado. Entendemos, de acordo com PELLEGRINI (2000) que a adoção desse modelo complementar e diferenciado de organização de serviços de saúde indígena vem buscando tornar factível e eficaz a aplicação dos princípios e diretrizes da universalidade, descentralização, equidade, participação comunitária e controle social que orientam o SUS.

Os 34 Distritos Sanitários Especiais Indígenas - DISEI - foram caracterizados como unidades organizacionais de responsabilidade da Fundação Nacional de Saúde, estabelecidas a partir de uma população e território definidos por critérios sócio-culturais, geográficos, epidemiológicos e de acesso aos serviços. Organizaram-se a partir das terras indígenas, com 
capacidade de desenvolver ações de atenção básica à saúde, articuladas com a rede regional do SUS.

O projeto de lei do Deputado Arouca, que resultou na Lei no. 9836/99, de criação do Sub-sistema de saúde indígena, coloca ao Estado a necessidade não só de disponibilizar serviços médicos, mas também proporcionar meios necessários às comunidades indigenas para exercerem o controle sobre sua saúde. Neste aspecto, assegurar a eqüidade significa reduzir diferenças entre o estado de saúde e condições de vida dos povos indígenas entre si e os demais segmentos do povo brasileiro, garantindo a igualdade de oportunidades e trazendo à tona questões de complexidade $\mathrm{e}$ relevância sócio-política, como a paz, regularização da situação fundiária, ecossistema saudável, educação, renda e justiça social, aspectos abrangentes e fundamentais da concepção de promoção da saúde. Parece haver uma grande distância entre essas concepções e a prática de organização e trabalho dos DISEI, centrados na oferta de assistência médica através de convênios de prestação de serviços.

Em primeiro lugar, há que se considerar o modelo de implantação e gestão adotado. A opção de firmar convênios para terceirizar a execução de assistência à saúde entre a FUNASA e organizações indígenas, indigenistas, municípios e universidades necessita ser analisada criteriosamente quanto a sua efetividade e suficiência frente a princípios políticos-ideológicos e desafios tão amplos.

Apesar dos importantes empreendimentos realizados no sentido da organização dos serviços, o objetivo de contemplar as especificidades de cada povo indígena e caminhar no sentido da construção social da saúde está longe de ser superado.

As dificuldades de entendimento, implantação e sustentação do modelo têm sido enormes, de acordo com avaliação da própria FUNASA (MINISTÉRIO DA SAÚDE, 2001a). 
Embora o processo seja muito recente, alguns erros e acertos podem ser identificados.

Para RODRIGUES E MENDONÇA(2000), a sustentabilidade do modelo proposto passa por intervenções do gestor federal do sub-sistema, principalmente quanto a alocação de recursos, diretrizes técnicas e políticas, acompanhamento e avaliação da operacionalização e sua atuação como facilitador na consolidação do SUS regional.

No plano local do sistema, o maior esforço deve ser concentrado em:

1. estruturação a equipe multiprofissional, o que passa pela implantação de uma política diferenciada de recursos humanos;

2. profissionalização dos agentes de saúde e instrumentalização para o trabalho com o apoio de processos de supervisão contínua e normalização técnicas dos agravos de saúde mais comuns;

3. articulação das ações de saúde de modo interdisciplinar e intersetorial às áreas de educação, meio ambiente, desenvolvimento sustentado, associações indígenas, etc. e

4. estruturação do controle social na forma do Conselho Distrital de Saúde.

O modelo proposto prevê a participação indígena através dos Conselhos Distritais de Saúde, de composição paritária entre usuários indigenas $(50 \%)$, prestadores de serviço $(25 \%)$ e profissionais de saúde (25\%) que deliberam sobre atividades complexas como a elaboração do plano de saúde distrital, avaliação das ações e apreciação de contas dos prestadores de serviços. 
Algumas falas colhidas em uma oficina de conselheiros indígenas no Xingu e lideranças para debater a saúde em maio de 2000 exemplificam a complexidade e o distanciamento do modelo proposto com a realidade, e apontam para a necessidade de intensificar o diálogo intercultural na composição do modelo de gestão da saúde.

"Eu não sei o que é isso, ministro da saúde" Kuiussi Suiá, cacique Suiá, 2000

"O distrito é novo, ainda não deu fruta. Mais uns 10 ou 20 anos, pode ser entregue na mão do índio que vai se capacitar. Esta planta nós fizemos, tem o desenho, é o que nós queremos fazer. Falta conversa, tem que tá todo mundo, tem que decidir"

Ararapã Trumai, liderança Trumai, 2000

"Decisão para nós é como fazer roça para o cacique. Cada povo tem um costume de decidir. A mulher do cacique é importante, ela coordena o pessoal, depois da roça pronta, leva comida para o pessoal. Eu não entendo como o pessoal branco decide as coisas." Kamani Suiá, chefe do PI Diauarum, 2000

"Será que estou doido? Se a saúde melhorou, porque as doenças aumentaram? Antes avião era difícil, agora tem avião toda hora. Tem as enfermeiras que a gente queira, do jeito que a gente queria. Agora queremos mais aulas e professores, tem que ter mais equipamento, porque o dinheiro some na mão do branco mas o equipamento fica aqui"

Ataki Txicão, liderança Ikpeng,2000

Há que se aprofundar a compreensão sobre as novas relações dos povos indígenas, destacando-se desde já que esses se encontram em diferentes situações de contato e niveis de participação política nos Estados na América Latina.

Para GHON, (1997) a nova concepção entre Estado-sociedade reconhece como legítima a existência de uma série de instituições situadas entre o mercado e o estado, exercendo um papel de mediação entre coletivos de indivíduos organizados $e$ as instituições do sistema governamental. 
Para a autora, há grandes alterações em curso, expressas inclusive em novas palavras: institucionalização, solidariedade, ocupação do espaço simbólico e cultural, parcerias, pluralidade, diversidade. Parece-nos importante debater esse movimento de idéias de modo crítico e profundo, sem o deslumbramento das soluções aparentemente fáceis e novas.

Este novo espaço de relações vem sendo pautado por princípios da ética e solidariedade como valores motores de suas ações. A questão que se apresenta, é dos limites de um novo papel de mediação frente às novas conjunturas sociais.

Gostaria de situar a análise da formação de agentes indígenas de saúde e dos recursos humanos como um todo, nessa conjuntura complexa, procurando compreender seus papéis de mediação e mudança.

Retomamos as concepções sobre recursos humanos apresentadas no início do estudo:

1. que os trabalhadores de saúde são sujeitos sociais, participantes da construção das suas práticas de ensino e trabalho e produtores coletivos de mudanças em diferentes níveis;

2. que o trabalho é o melhor lócus de formação, a medida que ocorre uma interação dinâmica entre os aspectos culturais, sociais e políticos da realidade.

Compreender e analisar o ambiente, contexto de vida e trabalho dos agentes indígenas de saúde e suas determinações no processo de formação parece de fundamental importância para o avanço da discussão no sentido da sua profissionalização e inserção institucional. É preciso conhecer as singularidades e suas possibilidades de ligação com o todo. 


\section{A profissionalização}

Em um sentido mais amplo, a profissionalização pode ser definida como um conjunto de ações através das quais uma profissão ou semiprofissão pode elevar seu prestígio, poder e ganhos (OLIVEIRA 1998).

Para ELIAS (1994), o processo de profissionalização é um dos traços mais importantes e distintivos das modernas sociedades ocidentais.

Retornamos então a questão inicial: porque profissionalizar os índios na área da saúde?

Este estudo evidencia que a profissionalização vem se caracterizando como uma opção de sobrevivência e construção de cidadania para os povos indígenas.

A condição do ser profissional parece afastar ou aproximar o indivíduo do seu contexto inicial de vida. Obrigatoriamente produz novos papéis e mudanças sociais.

Os pequenos indícios aqui encontrados demonstram que a profissionalização em contextos de grandes diferenças étnicas e culturais, como no caso estudado, pode requerer vários outros tipos de competências, reconhecimento e legitimações além do instituído formalmente pelos órgãos de classe e instituições.

A profissão dos AIS, situada na fronteira de muitos mundos, necessita de mecanismos de adequação política e institucional para a sua condição especial. Tudo é novidade. Um espaço novo de trabalho, sendo ocupado por novos sujeitos profissionais. 
Há que se fazer um exercício crítico e vigilância constante para não se reproduzir as perversidades da divisão social e técnica do trabalho nas áreas indígenas brasileiras.

Sem a pretensão de buscar soluções imediatas e ingênuas, apontamos o fortalecimento do trabalho em equipe, e a identificação de pessoas, experiências e instituições que possam ser tomadas como referências e conselheiros tanto indígenas quanto não indígenas são imprescindíveis para nortear o trajeto de novas experiências e oportunidades.

\section{A institucionalização}

A discussão sobre as formas de inserção profissional nas equipes de trabalho e de vinculação institucional de agentes comunitários de saúde vem sendo debatida há vários anos. Parece que os programas de saúde da família contém esse paradoxo: estão propostos como estratégia de efetivação de um sistema formal de saúde e baseiam-se no trabalho de um sujeito profissional não reconhecido legalmente e com grandes limitações para vinculação formal.

O conceito de vinculação institucional abrange a dimensão jurídica da relação de trabalho e a dimensão administrativa da relação institucional. As decisões tomadas oscilam entre o ponto de vista do trabalhador e do alcance social das estratégias politicamente adotadas.

NOGUEIRA e col. (2000), discutindo a inserção de agentes comunitários de saúde no geral, recomendam que essa seja efetuada com base nas relações formais de trabalho, capazes de assegurar 0 atendimento a seus direitos sociais e também contemplando o perfil social de trabalhador sui generis, no sentido da sua identificação com a comunidade onde se origina e o trabalho solidário que executa. Os autores defendem que a 
conotação comunitarista desses programas explicitam um novo paradigma de política social que começa a ser entendido e ensaiado pelo Estado, mas que no entanto, ainda não encontra condições concretas para sua generalização.

A questão da vinculação institucional dos agentes comunitários está determinada, e talvez seja uma questão de tempo efetiva-la, mas torna-se particularmente problemática devido aos impasses peculiares a essa fase de transição política.

Ao desempenhar a propalada função de elo com a comunidade, os agentes comunitários em geral ficam vulneráveis aos conflitos de opinião que vêm marcando a redefinição das relações entre o Estado e a comunidade.

Uma interpretação utilitarista, na visão de ANDERSEN (1990), é a de que os agentes comunitários expressam a ampliação da cidadania social, cuja culminância é dada pelo Estado de Bem-Estar. Corresponde a um esforço gradual de ampliação dos direitos sociais. O recurso humano do agente comunitário, tecnologicamente simplificado, e facilmente disponivel, seria utilizado para o fim de alcançar uma política de bem-estar em comunidades carentes (NOGUEIRA e col. 2000).

Uma visão mais recente situa o papel social dos agentes comunitários na mediação entre Estado e comunidade, não sendo exclusivo de nenhum dos dois. A visão solidarista compreende que a sociedade civil deve a si própria obrigações morais mínimas, a começar pela solidariedade. $O$ agente comunitário no sentido genérico ajuda a abrir as portas da ajuda solidária e fortalece $o$ acesso aos direitos sociais e participação de comunidades pouco atendidas pelo Estado.

$O$ incentivo governamental e o financiamento internacional para programas de formação de agentes de saúde podem ser vistos como um exemplo recente da expressão do paradigma solidarista das políticas sociais, 
centrado na potencialização de ações desenvolvidas em comum entre o Estado, sociedade civil e comunidade.

Para SANTOS (2001), esse é um novo movimento social que faz uma certa oposição ao Estado empresário, de corte neoliberal. Propõe uma articulação privilegiada entre os princípios do Estado e comunidade sobre a égide desse último. Parece haver um senso político progressista no movimento, de combate às políticas neoliberais.

Nas condições brasileiras, o trabalho dos ACS e dos AIS aparecem em uma fase em que a sociedade civil não dispõe de entidades capazes de oferecer uma parceria ampla e forte para dar conta dessas ações. Os AIS, que não têm sequer definida a condição de cidadania, estão sofrendo individualmente pela falta de um suporte institucional da solidariedade que não esteja arraigado na sociedade civil.

A diversidade dos "patrões",expressa nos convênios da FUNASA para implantação dos DISEI e nos modos de gestão que albergam a formação dos AIS e a gestão cotidiana do trabalho são exemplares no sentido dessa imaturidade institucional e da falta de interlocutores capacitados na sociedade civil.

As alternativas possiveis de vinculação institucional passam por parcerias entre instituições empregadoras que ofereçam uma estabilidade mínima, como as secretarias de saúde e entidades privadas não lucrativas, que possibilitem maior autonomia e controle da comunidade.

Este estudo demonstra que a posição do AIS é bastante frágil e dinâmica. Ele pode migrar de um lado para outro, para burocracia de Estado, mercado, ou ainda buscar novas composições e inserções sociais, como por exemplo, no chamado terceiro setor. Sua formação profissional extrapola em muito a dimensão técnica; aponta novas alternativas e caminhos de representação política e social para os povos indígenas. 
A análise política nos leva a crer que a superação da condição de desassistência à saúde dos povos indigenas faz parte de um aprendizado histórico e político-institucional. 0 estudo abordou temas políticos que estão em efervescência, apresentam alta complexidade teórico -conceitual e ainda não tem desdobramentos práticos no sentido de disponibilização de instrumentos e produtos que possam facilitar a resolução da problemática.

Há muito que se delinear no plano das novas responsabilidades, atribuições pessoais e institucionais como por exemplo, a composição do perfil de competências dos profissionais tradicionais de saúde sejam médicos, enfermeiros, dentistas e profissionais não tradicionais como antropólogos e educadores e os profissionais indígenas, inseridos em novas e velhas categorias profissionais.

Sem negar os avanços da construção do sub-sistema de saúde indígena no campo do SUS, há que se pensar e exercitar a composição de um perfil conjunto de equipe profissional compativel com as propostas de profissionalização, extrapolando sua abordagem individual e rediscutindo-se as interfaces com os modelos assistenciais de saúde pública e sua pertinência para com a saúde indígena.

A interlocução administrativa e com a burocracia de Estado também precisa ser ampliada e dialogada, não no sentido de concessões e negociações, mas na busca de soluções pactuadas para legitimar e legalizar o trabalho sui generis dos profissionais indigenas. 


\section{CONSIDERAÇÕES FINAIS}

Este estudo procurou apreender a complexidade dos processos de formação e trabalho de agentes indígenas de saúde ocorridos na década de 90. Teve como objetivo final a análise da construção das políticas de formação dos AIS, referenciada na experiência de trabalho de saúde do Parque Indígena do Xingu.

Partiu-se da premissa de que esta é uma realidade complexa, e os sujeitos sociais que a constróem são produtores de conhecimentos e mudanças de suas práticas de ensino, aprendizagem e trabalho.

O percurso metodológico foi orientado por uma pesquisa documental e vivências de campo, que possibilitaram a composição de diversos enfoques de análise.

Optou-se em uma primeira abordagem, no aprofundamento interdisciplinar dos enfoques da educação crítica, antropologia da educação e política de saúde.

A pesquisa evidenciou uma prática social em construção, com significativos avanços em algumas áreas e muitas vulnerabilidades.

Sua relevância e destaque político nos anos recentes, podem ser atribuídos à emergência do paradigma solidarista das políticas sociais e ao fortalecimento do movimento indígena na América Latina como um todo, que traz em sua pauta de reivindicações a formação profissional dos indígenas.

Constatou-se avanços conceituais e metodológicos nas práticas de formação, com identificação ao referencial legislativo da educação profissional de nível básico, sendo possivel a progressividade para o nivel técnico e articulação com várias carreiras profissionais da área da saúde. 
No campo da antropologia, verificou-se que os AIS fazem parte de uma fronteira cultural, um espaço de trânsito no qual exercem um papel complexo de articulação e troca de conhecimentos, e também de incompreensões e redefinições identitárias.

Por tratar-se de um movimento novo e complexo não se pode afirmar que exista uma política nacional de formação de recursos humanos para área de saúde indígena. Há diretrizes e referências baseadas em algumas experiências, como a do PIX, e que não podem ser aplicadas de modo genérico, em razão das muitas especificidades étnicas, culturais, sociais e políticas que permeiam o processo.

Analisando-se a inserção profissional e institucional dos trabalhadores indígenas, observa-se muitas fragilidades. A categoria de agentes de saúde ainda não é legalmente reconhecida e os impedimentos legais e burocráticos para inclusão desses trabalhadores no sistema de saúde não são poucos.

Podemos considerar que:

- a formação de AIS vem se caracterizando como um processo políticosocial e cultural recente e dinâmico;

- impacto epidemiológico das ações preventivas e de tratamento simples executadas pelos AIS, a exemplo do que ocorre nos programas de saúde da família é significativo;

- a sistematização dos processos de formação, consideradas as especificidades de cada realidade e a vinculação ao aparelho formador é uma condição sine qua non para a sua legitimação e legalização;

- processo de formação de AIS vivenciado no Xingu há 12 anos, promoveu o consenso para a construção coletiva do conhecimento, expôs e valorizou as características do saber e os modos de aprender das culturas do Xingu, fortalecendo a participação política e o processo de tomada de 
decisões na gestão da saúde no PIX. Trouxe qualidade para a prática cotidiana, mediante o acompanhamento sistemático do trabalho, uso de instrumentos pedagógicos e normatização de condutas médicas. Por outro lado, como nos demais processos de profissionalização que vem ocorrendo no Xingu, ampliou o deslocamento do foco de poder das chefias tradicionais para esses novos sujeitos, gerando conflitos em diferentes niveis. Imprimiu maior nivel de exigência para o trabalho dos profissionais de campo, já sobrecarregados e pouco capacitados para assumir a formação no trabalho;

- as práticas normativas e centralizadoras do órgão gestor da saúde indígena na esfera da formação têm sido controversas. Se por um lado impulsionam a capacitação em serviço e valorizam o processo ensinoaprendizagem no trabalho, por outro desconsideram as especificidades regionais e as diferentes concepções pedagógicas que poderiam ser aplicadas;

- a formação profissional é necessária mas não suficiente para a ordenação dos sub-sistema de saúde indígena e promoção da cidadania indígena. Os atuais DISEIs são um campo dinâmico de aplicação da formação de recursos humanos para a saúde indígena, e refletem embates e conflitos de outros cenários e realidades. Extrair desse contexto elementos facilitadores do trabalho pedagógico, parece ser uma operação complexa e que requer um perfil de múltiplas habilidades dos profissionais responsáveis;

- a superação da desassistência à saúde das populações indígenas, faz parte de um aprendizado histórico e político institucional que tem tido ganhos qualitativos a medida em que a participação social indígena aumenta. Esse movimento parece guardar relação com a evolução dos modelos assistenciais e práticas de saúde pública, que ainda está calcado ainda em ações eventuais e atomizadas; 
- perfil pessoal dos AIS brasileiros reflete diretamente a realidade sóciocultural na qual estão inseridos. Predominam adultos jovens do sexo masculino, que têm o domínio da língua portuguesa e da escrita e uma inserção diferenciada em suas comunidades de origem. Há oscilações quanto à permanência no trabalho, sendo comum um movimento de aproximações e afastamentos ainda pouco compreendido do ponto de vista institucional;

- perfil de trabalho aponta para um trabalhador genérico, de identidade comunitária, que realiza atividades não restritas ao setor saúde, passando pela mediação cultural e liderança política;

- a inserção profissional vem ocorrendo de modo incipiente e conflituoso através de contratos precários de trabalho ou remuneração por prestação de serviços;

- a vinculação institucional, praticamente inexistente, passa pela articulação com a burocracia pública nas principais agências governamentais FUNAI, FUNASA e Ministério da Saúde e sua caracterização jurídica frente aos modelos de Reforma do Estado. As possibilidades de vinculação vêm se aproximando das parcerias entre o setor estatal e o terceiro setor, nas modalidades de entidade filantrópica tradicional, ONG comunitária e ONG que agregue os ACS;

- a delimitação dos papéis profissionais, políticos e culturais dentre os novos sujeitos profissionais indígenas não está clara, situação geradora de conflitos internos e externos, sobrecarga de trabalho e consequências negativas.

Frente as evidências e possibilidades que emergiram dos diferentes campos de análise, podemos recomendar: 
- o acompanhamento do diálogo interétnico e intercultural na área da saúde, partindo da realidade indígena e alcançando outras realidades permeadas pela diversidade cultural;

- aprofundamento de estudos e pesquisas na área, a fim de se compor um arcabouço teórico conceitual voltado para a realidade indígena brasileira a partir do pensamento complexo que contemple a interdisciplinaridade, multiculturalidade, eqüidade, participação, autonomia e emancipação da cidadania;

- o desenvolvimento de mecanismos político administrativos que promovam a inserção profissional e institucional dos AIS, enquanto categoria sui generis no sistema de saúde;

- o fortalecimento dos programas de formação de agentes de saúde, articulados à instituições formadoras identificadas com os princípios da educação profissional em saúde de modo progressivo, flexível, multicultural e contínuo;

- legitimação das experiências acumuladas na prática de trabalho dos AIS mediante a certificação de competências, de acordo com as bases legais do sistema de ensino;

- aproveitamento do conhecimento coletivo produzido nas experiências bem sucedidas de formação, a exemplo do Projeto Xingu e do Projeto Xamã de Mato Grosso, de modo que seus princípios orientadores sejam avaliados, modificados ou validados em outras realidades;

- o desenvolvimento de parâmetros quanti-qualitativos de avaliação dos programas de formação de AIS, inclusive quanto aos aspectos de custos, impacto epidemiológico e organização dos serviços de saúde; 
- apoio às experiências que exercitem as novas responsabilidades institucionais, promovendo o diálogo interétnico argumentativo e a interlocução político-administrativa dos profissionais indígenas com a burocracia pública;

- composição de parcerias responsáveis com universidades, ONGs, órgãos públicos e associações indigenas para o enfrentamento dessa situação problema nas dimensões educativa, antropológica e política;

- o fortalecimento do processo ensino/aprendizagem no trabalho, valorizando as equipes multiprofissional locais e a atuação conjunta de profissionais indígenas com representantes dos sistemas tradicionais de cura, como pajés, rezadores, raizeiros e erveiros, incentivando a troca e produção de um novo conhecimento solidário e multicultural. 


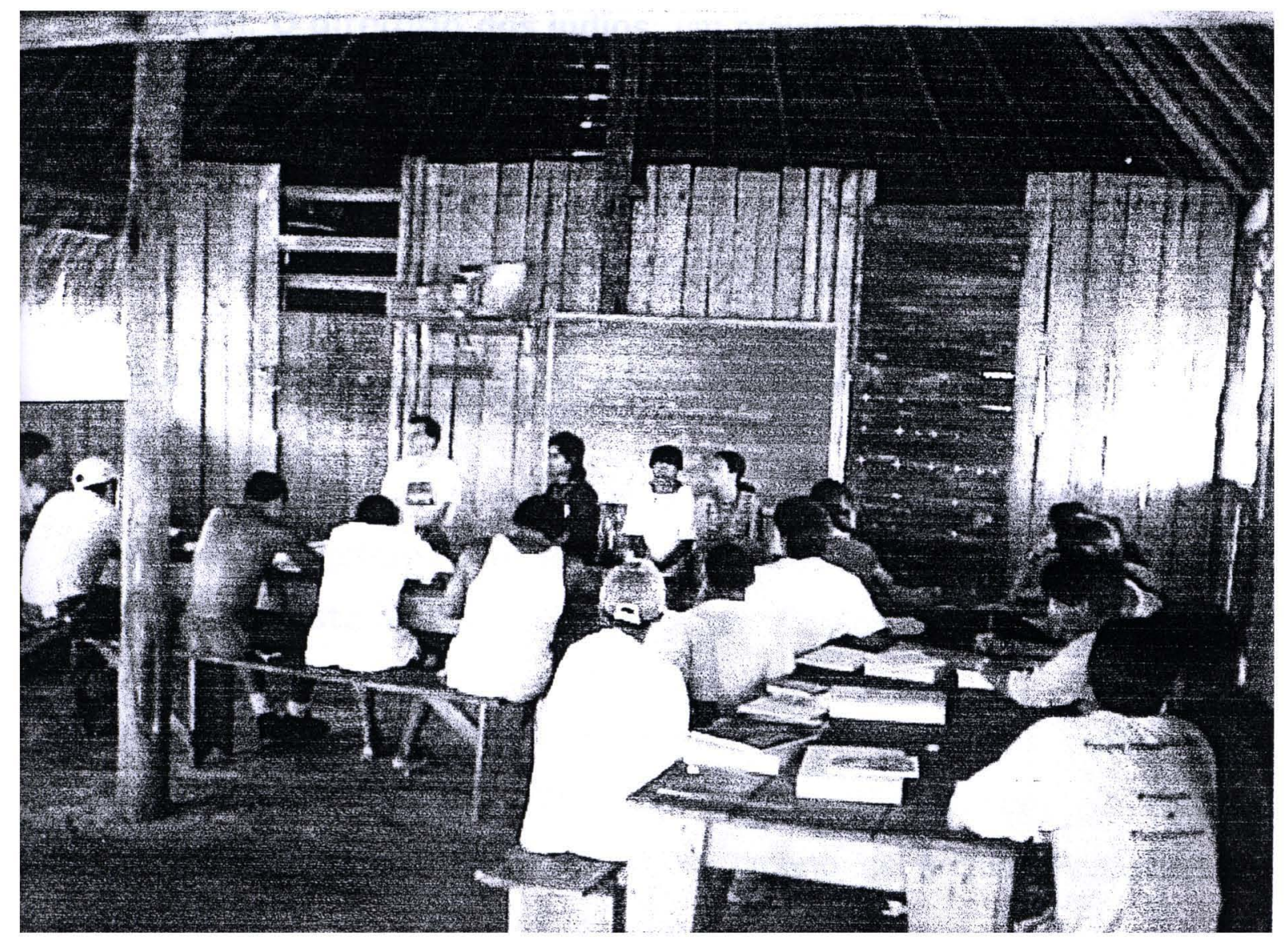




\section{REFERÊNCIAS BIBLIOGRÁFICAS}

AAISARN - Associação de Agentes Indígenas de Saúde do Rio Negro. Relatório da Oficina de Discussão sobre Formação de Agentes Indigenas de Saúde 1998. (mimeo)

Almeida RH. O diretório dos índios: um projeto de civilização no Brasil do século XVIII. Brasília: ed. UNB;1997.

Almeida RT. Breves comentários sobre a saúde e relações de contato: os Guarani brasileiros. Revista Saúde e Debate 1998; (nº esp.): 28-33.

Andersen EG. Three worlds of welfare capitalism. Princeton University Press; 1990.

Andrade LOM. Sistemas locais de saúde em municípios de pequeno porte. A resposta de Icapuí. Fortaleza: Expressão Gráfica e Editora; 1992.

Angelis WRD. A educação escolar em novos contextos políticos e culturais. In: VEIGA J e SALANOVA A. (org) Questões de Educação Escolar Indígena: da formação do professor ao projeto de escola. Funai/Dedoc, Campinas; 2001.

Arantes R. Saúde Bucal de uma comunidade indígena Xavante do Brasil Central: uma abordagem epidemiológica e sócio antropológica. Rio de Janeiro, 1998. [Dissertação de Mestrado] Escola Nacional de Saúde Pública.

Arroyo MG. As bases da educação popular em saúde. Rio de Janeiro, Tema/Fiocruz, p.7-9 2001. 
Athias R, Machado M. A saúde indígena no processo de implementação dos distritos sanitários: temas críticos e propostas para um diálogo interdisciplinar. Cad. Saúde Pública, 2001; 17(2): 425-431.

Banks-Leite L, Galvão I. A Educação de um selvagem - As Experiências pedagógicas de Jean Itard. São Paulo: Cortez; 2000.

Barth F. Other knowledge and other ways of knowing. J. Antropological Research, 1995; 51.

Baruzzi RG. Os índios do Parque Indígena do Xingu e suas condições de saúde e doença. Atuação da Escola Paulista de Medicina. Belém: Museu Paraense Emílio Goeldi. Coleção Eduardo Galvão, 1989; 39-49.

Baruzzi RG. Projeto Xingu. Unidade de Saúde e Meio Ambiente. São Paulo. Unifesp 2001. (mimeo)

Baruzzi RG, Canó EN, Santana G. Blood Pressure, Body Mass and glucose blood levels in indians from the Xingu Indigenous Park, Central Brazil, related to 70, 1985 and 1999. (mimeo) Unidade de Saúde e Meio Ambiente. Unifesp, 2000. Presented at $1^{\circ}$ Convention of Diabetes in Aboriginal Peoples; Winnipeg; 2000.

Baruzzi RG, Barros VL, Rodrigues D, Souza ALM. Saúde e doença em índios Panará (Kreen-Akôre) após vinte e cinco anos de contato com o nosso mundo, com ênfase na ocorrência de tuberculose. Cad. Saúde Pública $2001 ; 17(2)$ : 407-414.

Brasil. Decreto lei no 1141, de maio de 1994. Rege o Decreto no 23 que disciplina condições para prestação de assistência à saúde das populações indigenas. Diário Oficial da República Federativa do Brasil, Brasilia, agosto 1999. 
Brasil. Decreto lei n 2208 , de 17 de abril de 1997. Dispõe sobre a educação profissional de nível técnico. Diário Oficial da República Federativa do Brasil, Brasília, 1997.

Brasil. Decreto lei no 23, de fevereiro de 1991. Disciplina condições para prestação de assistência à saúde das populações indígenas. Diário Oficial da República Federativa do Brasil, Brasília, fevereiro 1991.

Brasil. Decreto lei no 3156, de 27 de agosto de 1999. Dispõe sobre as condições de prestação de assistência à saúde das populações indígenas no âmbito do SUS. Diário Oficial da República Federativa do Brasil, Brasília, agosto 1999.

Brasil. Lei no 9649, de 27 de maio de 1998. Dispõe sobre a organização da Presidência da República e dos Ministérios e dá outras providências. Diário Oficial da República Federativa do Brasil, Brasília, 1998.

Brasil. Medida Provisória no $1911-9$ de 27 de agosto de 1999. Altera os dispositivos da Lei no 9649 de 27 de maio de 1998 que dispõe sobre a organização da Presidência da República e dos Ministérios e dá outras providências. Diário Oficial da República Federativa do Brasil, Brasília, 28 agosto 1999.

Brasil. Medida Provisória no 1011-10 de 24 de setembro de 1999. Altera os dispositivos da Lei no 9649 de 27 de maio de 1998 que dispõe sobre a organização da Presidência da República e dos Ministérios e dá outras providências. Diário Oficial da República Federativa do Brasil, Brasília, 1999.

Brasil. Medida Provisória no 1911-8 de 29 de julho de 1999. Altera os dispositivos da Lei no 9649 de 27 de maio de 1998 que dispõe sobre a organização da Presidência da República e dos Ministérios e dá outras 
providências. Diário Oficial da República Federativa do Brasil, Brasília, 1999.

Brasil. Projeto de Lei no 2057/96. Dispõe sobre o estatuto das sociedades indígenas, Brasilia, 1996.

Brasil. Projeto de Lei no 4681 /96. Dispõe do funcionamento dos serviços de saúde para populações indígenas, Brasília, 1996.

Brasil. Lei no. 9.394/96 de Diretrizes e Bases da Educação, Brasília, 1996.

Buarque de Holanda S. Caminhos e fronteiras. São Paulo, Cia das Letras; 1994.

Campos GWS. Subjetividade a administração de pessoal: considerações sobre modos de gerenciar trabalho em equipes de saúde. In: Merhy EE; Onocko R. (org) Praxis en salud - um desafio para lo publico. São Paulo: HUCITEC; 1997.

Capistrano Filho D. O Programa de Saúde da Família em São Paulo, 1997 [folheto de divulgação].

Carvalho MA, Acioly S, Stotz E. O processo de construção compartilhada do conhecimento: uma experiência de investigação científica do ponto de vista popular. In: A saúde nas palavras e nos gestos. Rio de Janeiro: Elos; 2001.

Coimbra CEA, Santos RV. Saúde, minorias e desigualdades. Algumas telas de interrelações com ênfase nos povos indígenas. In: Livro de resumos do VI Congresso Brasileiro de Saúde Coletiva; Salvador, Ba: ABRASCO; 2000. p. 9. 
Confalonieri UEC, Marinho DP. As populações indígenas no Brasil. In: Confalonieri UEC. (org). Saúde de populações indígenas. Uma introdução para profissionais de saúde. Rio de Janeiro: Escola Nacional de Saúde Pública; 1993.

[CNS] Conselho Nacional de Saúde. Revista da Saúde. 2000; 1(1).

Cordeiro E. Política Indigenista Brasileira e Promoção Internacional dos Direitos das Populações Indígenas. Brasília, Instituto Rio Branco. Centro de Estudos Estratégicos; 1999.

Costa DC. Política indigenista e assistência à saúde - Noel Nutels e o Serviço de Unidades Sanitárias Aéreas. Cad Saúde Pública 1987; 4(3): 388-401.

Costa MR. Estamos no Caminho certo. Conselho Nacional de Saúde Revista da Saúde. 2000; 1(1): 16-18.

Davini MC, Haddad J. Proceso de trabajo y Educacion Permanente de Personal de salud: reorientacion y tendencias en America Latina. Educ. Med Salud 1991; 24(2).

Elias N. O processo civilizador. Uma história dos costumes. Rio de Janeiro: Jorge Zahar; 1994.

[EPM] Escola Paulista de Medicina. Programa de Atenção à saúde no Xingu.1989. (mimeo)

EPPS AC. Effective Strategies and Programs to Increase Minority Participation in the Health Professions for the $21^{\text {st }}$ Centuriy. Journal of the Association for Academic Minority Physicians. 1993; 4(4): 116-126. 
ETNOLLANO. Saude sentir de todos. Video Fundacion Etnollano. Programa COAMA. Bogotá, Colômbia, 1995.

Fazenda I. (org) Metodologia de pesquisa educacional. São Paulo: Cortez; 1994.

Ferrari JO. A saúde dos índios. Um desafio sem endereço. Os Karitiana de Rondônia. São Paulo; 1995. [Dissertação de Mestrado] Faculdade de Saúde Pública da USP.

Figueiroa A. (org) Um estudo sobre o quadro epidemiológico indígena. Rev. Saúde, CNS 2000; 1(1): 20.

Fishmann R. Educação, democracia e questão dos valores culturais. In: Munanga K. Estratégias e políticas de combate à discriminação racial. São Paulo: EDUSP;1996.

[FNS] Fundação Nacional de Saúde. COSAI, Formação de Agentes Indígenas de Saúde. Brasília, 1999.

France C. (org) Do filme etnográfico à antropologia fílmica. Campinas: Ed. UNICAMP; 2000.

Freire P. Pedagogia da Autonomia. Saberes necessários à prática educativa. São Paulo: Paz e Terra; 2001.

Freitas MC. História, antropologia e a pesquisa educacional itinerários intelectuais. São Paulo: Cortez; 2001.

FSP/USP. Faculdade de Saúde Pública da Universidade de São Paulo. Proposta de capacitação pedagógica para instrutores/supervisores 
de áreas indígenas (mimeo). São Paulo: Faculdade de Saúde Pública USP; 1997.

[FUNAI] Fundação Nacional do Índio. Relatório Anual do Depto. de Saúde. Brasília; 1998 (mimeo).

[FUNASA] Fundação Nacional de Saúde. Formação de Agentes Indígenas de Saúde. Brasília; 1999.

[FUNASA] Fundação Nacional de Saúde. Relatório de Avaliação da Capacitação de Instrutores/Supervisores. Brasilia; 2000.

[FUNASA] Fundação Nacional de Saúde. Reflexões sobre o Planejamento de 2002. Brasília; 2001.

Gadotti M. Diversidade Cultural e Educação para Todos. Rio de Janeiro: Graal; 1996.

Galvão I, Dantas H. O lugar das interações sociais e das emoções na experiência de Jean Itard com Victor de Aveyron. In: Banks-Leite L; Galvão I. A Educação de um selvagem - As Experiências pedagógicas de Jean Itard. São Paulo: Cortez; 2000.

Gil AC. Métodos e técnicas de pesquisa social. São Paulo: Editora Atlas; 1994.

Gohn MG. Teoria dos movimentos sociais: paradigmas clássicos e contemporâneos. São Paulo: Loyola; 1997.

Gomes MP. Os índios e o Brasil. Petrópolis: Vozes; 1991. 
Hannerz U. Fluxos, fronteiras híbridos: palavras chaves da antropologia transnacional. Mana 1997; 3(1): 7-39.

Herrera ML. e Lobo M. (org.) Promocion de la salud desde la comunidad. Bogotá, Etnollano/IORC/COAMA. 1998.

[ISA] Instituto Sócio Ambiental. Povos Indígenas do Brasil. 1996-2000. Ricardo, B. (org.). São Paulo; 2000.

[INESC] Instituto de Estudos Sócio Econômicos. Porque regulamentar a profissão de agentes comunitários de saúde, $n^{\circ}$. 36. Brasilia, 1998.

Kriechbaum P. Health Development and indigenous peoples a New Zealland Study. Manawatu Health District. NZ 1993.(mimeo)

Langdon EJ. (org) Xamanismo no Brasil: perspectivas. Florianópolis, SC: UFSC; 1996.

Langdon EJ. Salud y pueblos indígenas: los desafios en el cambio del siglo. In Brieño Leon R. (coord).Salud y equidade: uma mirada desde las ciencias sociales. Rio de Janeiro: Fiocruz; 2000. p.107-117

Laville C, Dionne J. A construção do saber. Manual de metodologia de pesquisa em ciências humanas. Porto Alegre: Editora Artes Médicas Sul e Belo Horizonte: Editora UFMG; 1999.

Martins CL, Oliveira LSS, Watanabe HA. Agentes comunitários no serviço de saúde pública: elementos para uma discussão. Revista Saúde e Debate 1996; 51: 38-43.

Mayombana $\mathrm{C}$ e col. Training of village health workers in Tanzania: a comparison of two approaches. Tropical Doctor 1990 April; 63-67. 
Mendes EV. (coord) Distrito sanitário: o processo social de mudança das práticas sanitárias do Sistema Único de Saúde. São Paulo: HUCITEC-ABRASCO; 1994.

Mendonça SBM. O agente indígena de saúde do Parque indígena do Xingu. São Paulo, 1996. [Dissertação de Mestrado - Pontifícia Universidade Católica de São Paulo].

Mendonça SBM. Política indigenista de saúde. Comissão Intersetorial de Saúde indígena. Conselho Nacional de Saúde. Brasília; 1999.

Merhy, EE. A rede básica como uma constrição da saúde pública e seus dilemmas. In: Merhy EE.; Onocko R (org.) Praxis en salud - um desafio para lo publico. São Paulo: HUCITEC;1997.

Minayo MC e cols. Programa de Agentes de Saúde do Ceará. Fortaleza. UNICEF; 1990.

Minayo MC. (org) Pesquisa Social: teoria, metodologia, criatividade. Petrópolis: Ed. Vozes; 1994.

Ministério da Educação. Educação escolar Indígena. Referênciais Curiculares. Brasília; 1999a.

Ministério da Educação. Parecer CNE 4/99. Educação Profissional. Brasília; 1999b.

Ministério da Educação. Diretrizes Curriculares Nacionais para o Ensino de Nivel Técnico. SEMTEC. Brasilia; 2000. 
Ministério da Educação. Educação Profissional: referenciais curriculares nacionais para Educação Profissional de nível técnico. SEMTEC. Brasilia, 2000a.

Ministério da Justiça. Fundação Nacional do Índio. Relatório anual do Departamento de Saúde. Brasilia; 1998.

Ministério da Saúde. Relatório Final da II Conferência Nacional de Atenção à saúde dos povos indígenas. Brasília; 1993.

Ministério da Saúde. Fundação Nacional de Saúde. Departamento de Operações. Coordenação de Saúde do Índio. Proposta de reorganização da assistência à saúde indígena - Distritos Sanitários Especiais Indígenas. Brasília; 1999a.

Ministério da Saúde. Fundação Nacional de Saúde. Departamento de Operações. Coordenação de Saúde do Índio. Formação de agentes indígenas de saúde. Brasília; 1999b.

Ministério da Saúde. Fundação Nacional de Saúde. Departamento de Operações. Coordenação de Saúde do Índio. Projeto VIGISUS - Gerência de $\mathrm{RH}$. Treinamento introdutório dos agentes indígenas de Saúde. Brasília; 1999c.

Ministério da Saúde. Fundação Nacional de Saúde. Departamento de Operações. Coordenação de Saúde do Índio. Formação de agentes indígenas de saúde. Propostas e diretrizes. Brasília; 1999d.

Ministério da Saúde. Fundação Nacional da Saúde. Proposta preliminar de implantação dos Distritos Sanitários Especiais Indígenas. Brasília; 1999e. 
Ministério da Saúde. Secretaria de Gestão. Projeto de Profissionalização dos Trabalhadores de Enfermagem - PROFAE. Brasília; 2000a.

Ministério da Saúde. Política Nacional de Atenção à Saúde dos Povos Indígenas. Fundação Nacional de Saúde, Brasília; 2000b.

Ministério da Saúde. Fundação Nacional de Saúde. Diretoria de Saúde Indígena. Perfil de morbi-mortalidade reportado pelos DISEI (mimeo dados preliminares), Brasília; 2001a.

nistério da Saúde. Fundação Nacional de Saúde. Departamento de serações. Diretoria de Saúde do Índio. Reflexões para o planejamento : 2002. Brasília; 2001b.

nistério da Saúde. Relatório Preliminar da III Conferência Nacional : Saúde Indígena.[on line] www.funasa.gov.br; 2001c.

rim E. Cultura de massas no século XX. Rio de Janeiro: Forense iversitária; 1990.

Jrim E. Ciência com consciência. Rio de Janeiro: Bertrand Brasil; 1996.

Igueira, Silva e Ramos. A vinculação institucional de um trabalhador i generis: o ACS. Rio de Janeiro: IPEA; 2000. (mimeo)

veira LSS. Aspectos éticos da relação intercultural: considerações bre o trabalho de profissionais de saúde. São Paulo; 1998. [Trabalho resentado à disciplina Ética da Saúde Pública] Faculdade de Saúde Pública USP. 
Oliveira LSS. Profissionalização de trabalhadores de enfermagem: Experiência do Projeto Larga Escala na cidade de São Paulo. São Paulo, 1996. [Dissertação de Mestrado] Faculdade de Saúde Pública da USP.

Oliveira RC. $\mathrm{O}$ índio e o mundo dos brancos. Campinas: Ed. UNICAMP; 1996.

Oliveira RC. Ação indigenista, eticidade e o diálogo interétnico. Estudos Avançados 2000; 40:213-230.

Oriá R. Educação, cidadania e diversidade cultural. São Paulo, Humanidades 1998; 151-159.

Paim JS, Almeida-Filho N. A crise da saúde pública e a utopia da saúde coletiva. Salvador: Casa da Qualidade Editora; 2000.

Pellegrini M. Povos Indígenas e a conquista da cidadania no campo da saúde. In: [ISA] Instituto Sócio Ambiental. Povos Indígenas do Brasil. 19962000. Ricardo, B. (org). São Paulo; 2000.

Pellegrini M. O preço da diferença: aspectos éticos e legais da assistência à saúde indígena. Informativo INESC 1998; 84.

Ribeiro D. O povo brasileiro. São Paulo: Companhia das Letras; 1997.

Ribas DLB, Sganzerla A, Zorzatto JR, Phillipi ST. Nutrição e saúde infantil em uma comunidade indígena Terena. Mato Grosso do Sul, Brasil. Cad. Saúde Pública 2001; 323-333.

Rodrigues D., Mendonça SBM, 2000 Distrito Sanitário e Saúde no PIX. In: [ISA] Instituto Sócio Ambiental Povos Indígenas do Brasil. 1996-2000. Ricardo, B. (org.) São Paulo; 2000. 
Sá ENC. Contradições e conflitos nas formas de organização da administração Pública para o Sistema Único de Saúde. Brasília, OPAS;1993. p. 23-35. (Série Direito e Saúde n² 2).

Sá Marques EO. Quando o currículo faz a diferença. O currículo integrado na formação do THD. Minas Gerais, 2001 [Dissertação de Mestrado] Pontificia Universidade Católica de Minas Gerais.

Santos BS. Para um novo senso comum: a ciência, o direito e a política na transição paradigmática. São Paulo: Cortez; 2001.

Schraiber LB, Peduzzi M. Tendências e possibilidades de investigação em recursos humanos no Brasil. São Paulo, (mimeo), 1992.

Sibthorpe B, Beecking FB. Positions and training of the indigenous health workforce. Aust.NZ Public Health 1998. Oct. (6): 648-52.

Silva AL. A educação indígena entre diálogos interculturais e multidisciplinares: Introdução In: Silva AL; Ferreira MKL. Antropologia, história e educação: a questão indígena e a escola. São Paulo: Global; 2001. p.9-21.

Silva JA. O agente de saúde do Vale do Ribeira. São Paulo, 1983. [Dissertação de Mestrado] Faculdade de Saúde Pública da USP.

Silva JA. O Agente Comunitário de Saúde do Projeto Qualis. Agente Institucional ou de Comunidade? São Paulo, 2001. [Tese de Doutorado] Faculdade de Saúde Pública da USP.

Solla Jj e cols O PACS na Bahia: avaliação do trabalho dos Agentes Comunitários de Saúde. Revista Saúde e Debate 1996; 51: 4-15. 
[SSL] Saúde Sem Limites. Capacitação de agentes indígenas de saúde do alto Rio Negro - Proposta de reformulação curricular. São Gabriel da Cachoeira; 1998. (mimeo)

Tassinari AMI. Escola indígena: novos horizontes teóricos, novas fronteiras de educação. In: Silva AL; Ferreira MKL (org.). Antropologia, história e educação: a questão indígena e a escola. São Paulo: Global; 2001. p. 44-70.

Torres C, Rio M. Etnia, pobreza e saúde na Região das Américas: uma visão histórica para compreender esta relação. In: Organización Panamericana de la Salud. Equidade em saúde pelo prisma da etnicidade. Washington, DC: OPS; 2001. p. 205-229.

Torres C. Etnicidade e saúde: outra perspectiva para alcançar a equidade. In: Organización Panamericana de la Salud. Equidade em saúde pelo prisma da etnicidade. Washington, DC: OPS; 2001. p.3-53.

[UNESCO] Princípios sobre a tolerância. S. Paulo, USP/FLLCH, 1997.

[USMA] Unidade de Saúde e Meio Ambiente. Universidade Federal de São Paulo. Relatório de Atividades; 1995.

[USMA] Unidade de Saúde e Meio Ambiente. Universidade Federal de São Paulo. Relatório de Atividades;1996.

[USMA] Unidade de Saúde e Meio Ambiente. Universidade Federal de São Paulo. $3^{\circ}$ Etapa de Concentração do Curso de Formação de Auxiliares de Enfermagem Indígenas;1998a.

[USMA] Unidade de Saúde e Meio Ambiente. Universidade Federal de São Paulo. Relatório de Atividades; $1998 \mathrm{~b}$. 
[USMA] Unidade de Saúde e Meio Ambiente. Universidade Federal de São Paulo. Relatório da Oficina de Trabalho. Articulando conteúdos do núcleo comum e núcleo profissionalizante. 13 a 16/3/1999; 1999a.

[USMA] Unidade de Saúde e Meio Ambiente. Universidade Federal de São Paulo. Relatório de Atividades; $1999 \mathrm{~b}$.

[USMA] Unidade de Saúde e Meio Ambiente. Universidade Federal de São Paulo. Relatório de Atividades; 2000.

Valla VV, Stotz EN. (org) Educação Saúde e Cidadania. Petrópolis: Vozes; 1994.

Varga IVD Indigenismo sanitário? Instituições, discursos e politicas indígenas no Brasil comtemporâneo. In Caderno de Campo Revista dos alunos de Pós-Graduação em Antropologia da Universidade de São Paulo, ano II, n' 2. São Paulo: Universidade de São Paulo/Faculdade de Filosofia Letras e Ciências Humanas/Departamento de Antropologia, 1992.

Veiga J, Salanova G. Questões de Educação Indígena da Formação do Porfessor ao Projeto de Escola. FUNAI/Brasília/Campinas; 2001.

Venezuela Ministerio de Sanidad y Servicio Social. Promotores Indígenas de Salud. Caracas, s/d.

Viveiros de Castro E. Images of Nature and Society in Amazon Etnology. Annual Review of Anthropology 1996; 25:179-200.

Weppner RS et alli. A review of Evaluation Literature on Health Professions Training and Enrichment Preograms for Minority/Disadvanteged Students. Washington, Journal of Health Administration 1999; 17(1):1-13. 
Young TK. Prevalence and correlates of hypertention in a Subarctics Indian Population. Preventive Medicine 1991; 20:474-485. 
ANEXOS

Anexo 1

Perfil de Morbi-mortalidade das populações indígenas do Brasil, 2001. FUNASA, 2001

Anexo 2 Mapa de Localização do Parque do Xingu e Perfil de Morbi- mortalidade das populações indígenas do Xingu, 1999.

Anexo 3

Lei 9.836, de 23 de setembro de 1999.

Anexo 4 Quadro de profissionais dos Distritos Sanitários Especiais Indígenas no Brasil, 2000.

Anexo 5 Listagem de relatórios utilizados como fontes documentais. USMAYUNIFESP.

Anexo 6 Proposta Modular do Curso de Capacitação de Agentes Indígenas de Saúde. FUNASA,2000.

Anexo 7

Proposta de Curso de Formação de Auxiliar de Enfermagem para Indígenas. Escola Técnica de Saúde/ MT, 1999-2000.

Anexo 8

Perfil dos AIS do Xingu.

Anexo 9 Perfil dos AISB do Xingu.

Anexo 10 Estrutura do DISEI Xingu

Anexo 11 Organização dos DISEI e fluxo de atenção à saúde.

Anexo 12 Planejamento dos cursos e supervisão dos AIS- Xingu

Anexo 13 Relação de Leis. Decretos e Pareceres consultados.

Anexo 14 Listagem de desempenhos e auto-avaliação dos AIS.

Anexo 15 Cronologia de viagens ao Xingu.

Anexo 16 Formação de Agentes Indígenas de Saúde- Avaliação de Produtos.

Anexo 17 Listagem de filmes e videos consultados. 


\section{Anexo 1}

Perfil de Morbi-mortalidade das populações indígenas do Brasil, 2001. Fonte: FUNASA, 2001. 


\section{Saúde Indígena}

It - Perfill Epidem iológ ico das Populações Indígenas

- D oenças do Aparelho Ciraula tório:

$2000=1.851 / \mathrm{H}$ ipertensão $=1.838$ 99,3\%)

$2001=5.357 / \mathrm{H}$ ịpertensão $=4.776(89,2 \%)-($ dados sujetos a revisão $)$

- D oenças Endócrinas e M etabólicas:

$2000=1.924 /$ Desnutrição $=1.441(74,9 \%) / D$ iabetes $=481(25,0 \%)$

$2001=5.456 /$ D esnutrição $=3.995(73,2 \%) / D$ iabetes $=1322 R 4,2 \%)$ dados sujeitos a revisão)

- O bitos por causas Endócrin as e M etabólicas:

$2000=179 /$ Desnutrição $=82(45,8 \%) /$ Desidratação $=54(\beta 0,2 \%)$

$2001=125 /$ D esnutrição $=33(26,4 \%) /$ esidratação $=67(53,6 \%)$

(dados suje itos a revisão)

- M a lária 27 D SED :

$2000=26.838 / \mathrm{V} \dot{\mathrm{I} a x}=18.075(67,5 \%) /$ Falcip $=6.761(25,2 \%) / \mathbb{P A}=96,8 \%$ 。

$2001=13.313 / \mathrm{V} \dot{\mathrm{I} a x}=10255(77,0 \%) /$ Falcip $=2.939(22,1 \%) / \mathbb{P A}=46,5 \%$

O BS: redução de $50,4 \%$ 


\section{Saúde Indígena}

Doenças mais reportadas pelos DSEls, segundo categorias CID10, 2000 - 2001*

\begin{tabular}{|c|c|c|c|c|}
\hline CID10 Ano & 2000 & $\%$ & 2001 & $\%$ \\
\hline DIP & 114.336 & 39,9 & 105.859 & 33,7 \\
\hline Ap. Respiratório & 92.516 & 32,3 & 90.302 & 28,7 \\
\hline Pele/Subcutâneo & 30.124 & 10,5 & 44.171 & 14,0 \\
\hline Indet./Mal Definida & 19.733 & 6,9 & 25.171 & 8,0 \\
\hline Ap. Digestivo & 10.096 & 3,5 & 5.014 & 1,6 \\
\hline Olho/Anexos & 6.044 & 2,1 & 9.966 & 3,2 \\
\hline Osteomuscular & 4.036 & 1,4 & 6.717 & 2,1 \\
\hline Sangue & 2.901 & 1,0 & 5.248 & 1,7 \\
\hline Metabolismo & 1.924 & 0,7 & 5.456 & 1,7 \\
\hline Ap. Circulatório & 1.851 & 0,6 & 5.357 & 1,7 \\
\hline Genitourinário & 1.608 & 0,6 & 4.441 & 1,4 \\
\hline Causas Externas & 1.487 & 0,5 & 6.669 & 2,1 \\
\hline Sistema Nervoso & 91 & 0,0 & 195 & 0,1 \\
\hline Gravidez/Parto & 66 & 0,0 & 14 & 0,0 \\
\hline Neoplasias & 5 & 0,0 & 4 & 0,0 \\
\hline Total & 286.818 & 100,0 & 314.584 & 100,0 \\
\hline
\end{tabular}

- Dados até outubro, sujeitos a revisåo 
Saúde Indígena

Mortalidade Proporcional por causas mais frequentes, nos menores de 5 anos.

DESAI, 2000 - 2001*

\begin{tabular}{l|rrrr|rrrrr}
\hline & \multicolumn{5}{|c|}{2000} & \multicolumn{5}{c}{2001} \\
\cline { 2 - 9 } Doenças & $<1$ & $\%$ & 1 a 4 & $\%$ & $<1$ & $\%$ & 1 a 4 & $\%$ \\
\hline Indet.Mal Definida & 116 & 17,68 & 51 & 22,27 & 156 & 38,81 & 70 & 37,84 \\
Ap. Respiratório & 152 & 23,17 & 67 & 29,26 & 76 & 18,91 & 29 & 15,68 \\
Perinatal & 176 & 26,83 & 0 & 0 & 56 & 13,93 & 0 & 0 \\
DIP & 103 & 15,7 & 46 & 20,09 & 38 & 9,453 & 31 & 16,76 \\
Metabolismo & 54 & 8,232 & 44 & 19,21 & 44 & 10,95 & 41 & 22,16 \\
Causas Externas & 22 & 3,354 & 8 & 3,493 & 11 & 2,736 & 8 & 4,324 \\
Malformações & 22 & 3,354 & 2 & 0,873 & 18 & 4,478 & 4 & 2,162 \\
Outras Causas & 11 & 1,7 & 11 & 4,8 & 3 & 0,7 & 2 & 1,081 \\
\hline Total & 656 & 100,0 & 229 & 100,0 & 402 & 100,0 & 185 & 100,0 \\
\hline
\end{tabular}

• Dados até outubro, sujeitos a revisão. 
Anexo 2

Mapa de localização do Parque do Xingu e Perfil de Morbi-mortalidade das populações indigenas do Xingu, 1999. Fonte: USMA/UNIFESP 


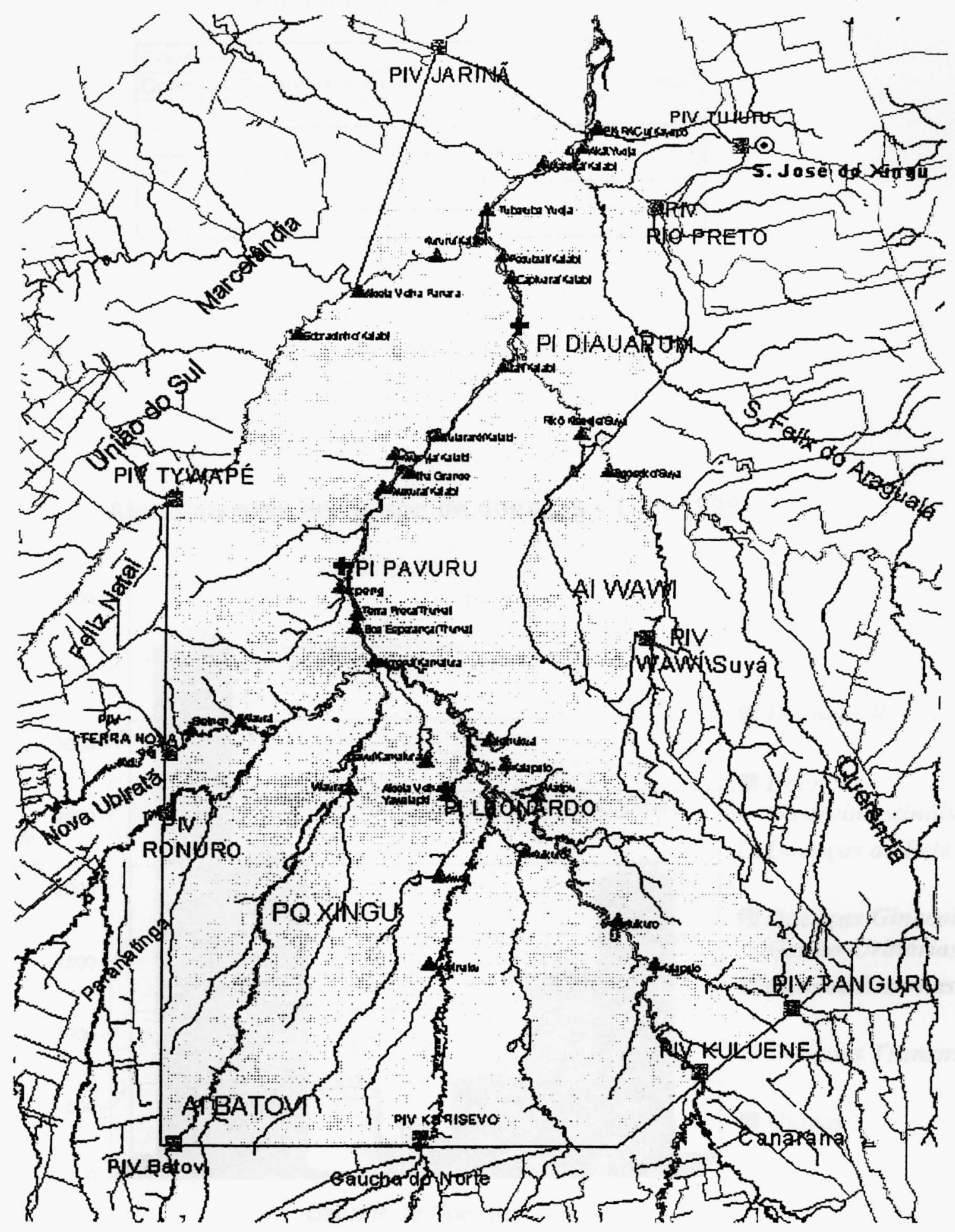

Fonte: Instituto Socioambiental - ISA, 1997 


\section{Gráfico}

Distribuição dos atendimentos por área de abrangência e grupos de doenças

Terra Indígena Xingu, 1999

\begin{tabular}{|l|r|}
\hline Doenças Respiratórias & 3.57 \\
\hline Doenças Gastrointestinais & 2097 \\
\hline & \\
\hline Causas Externas & \\
\hline & 574 \\
\hline Outras & \\
\hline
\end{tabular}

Atendimentos por grupo de doenças - TIX - 1999

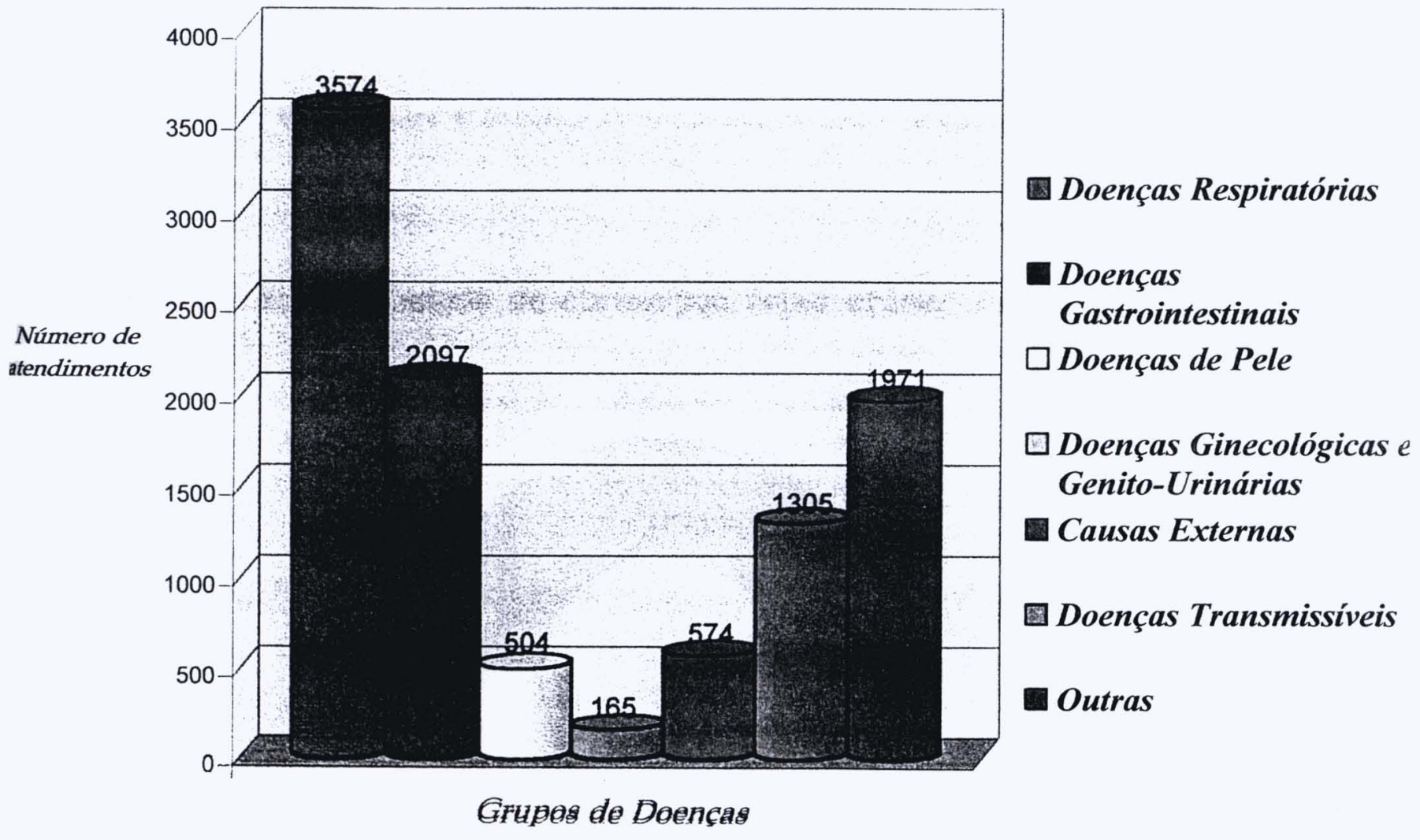


Gráfico 1 Distribuição das Causas de Martes Terra Indigena Xingu. 1999

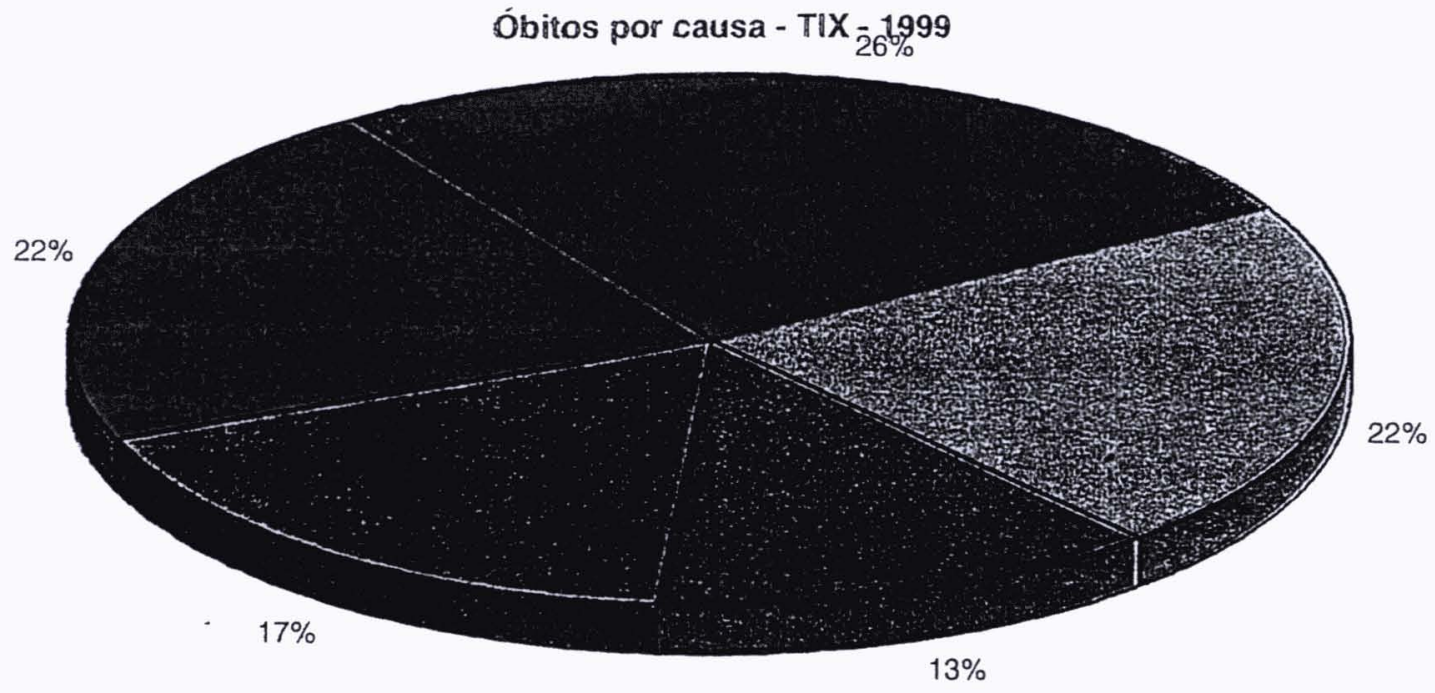

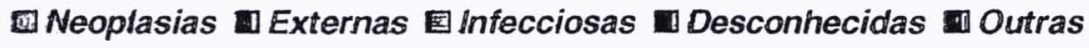

Gráfico 2 Distribuição de óbitos por faixa etária, DSEIX, 1999

Distribuiçãa de óbitos por faixa etária

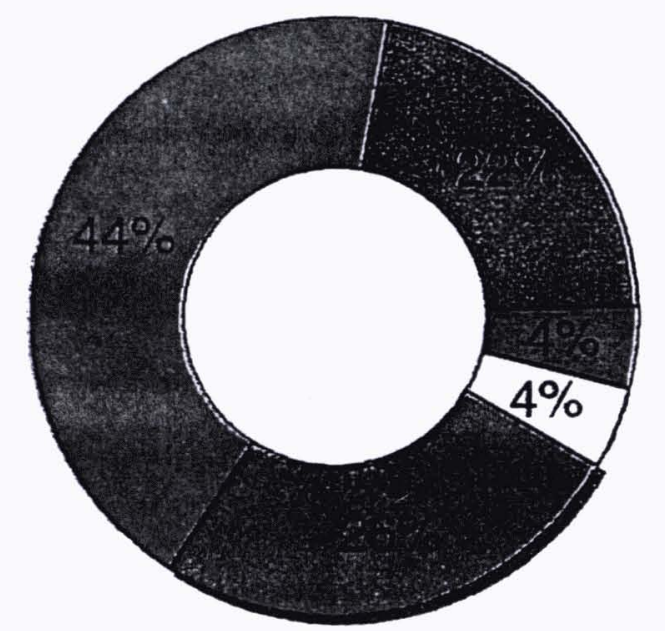

圆 0-1 ano 圆1-4 anos $\square 5-15$ anos 원 $15-49$ anos $50 e+$ 


\section{Anexo 3}

Lei no 9.836, de 23 de setembro de 1999 


\section{Lei $n .^{\circ} 9.836$, de 23 de setembro de 1999}

Acrescenta dispostivos a Ler $n=8080$, de 19 de setembro de 1990 , que "dispōe sobre as condiçoes para a promoção, provecăo e recuperaça da saude, a organizaçào e o funcionamento dos serviços correspondentes e dá outras providèncias". stitundo o Subsistema de Atencia a Savde tndigena

O PRESIDENIE DA REPUBLICA, taso saber que o Congresso Nacional decreta e eu sanciono a segunte le

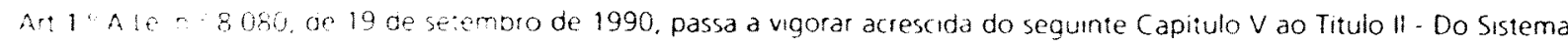
Ur co de buoc

\section{CAPITULO V}

Do Subsistema de Atençăo à Saúde Indigena

Ar: 19 - A As açoes e serviços de saúde voltados para o atendimento das populaçoes indigenas. em todo o território nar onal. coles va ou indwidualmente. obedecerāo ao disposto nesta Lei.

Ar: 19 - e E instuudo um Subsistema de Atençào à Saude Indigena, componente do Sistema Unico de Saúde - SuS, criado e cefinido po: esta Lei, e pela Lei $r^{\circ} 8142$, de 28 de dezembro de 1990 . com o qual funcionará em perfeita integraçāo.

Art 19 - C Caberá à Uniăo, com seus recurso próprios, financiar o Subsistema de Atençào à Saúde Indigena.

Art 19 - D. O SUS promoverá a articulaçào do Subsistema instituido por esta Lei com os órgāos responsáveis pela Politica ndigena do Pais.

$$
\text { a.t. }
$$

Af: 19 - E Os Estados, Municipios, outras instituiçōes governamentais e nāo-governamentais poderāo atuar complementarmente no custeio e execuçào das açōes.

$$
\therefore \quad \therefore
$$

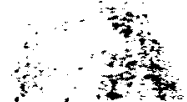

Art 19 - F Dever-se-a obrigatoriamente levar em consideraçào a realidade local e as especificidades da cultura dos povos ndigenas e o modelo a ser adotado para a atençào à saúde indigena, que se deve paưtar por uma abordagem diferenciada e global, contemplando os aspectos de assıstência à saúde, saneamento básico, nutrição, habitaçăo. meio ambiente, demarcação de terras, educaçāo sanitária e integração institucional.

Art 19 - G. O Subsistema de Atenção a Saude Indigena deverá ser, como o Sus, descentralizado, hierarquizado e regionalizado in:

$\S 1^{\circ}$ O Subsistema de que trata o caput deste artigo terá como base os Distritos Sanitarios Especiais Indigenas

$\$ 2^{\circ}$ O SUS servira de retaquarda e reterencia ao Subsistema de Atençào à Saúde Indigena, devendo, para isso, ocorrer idadiaçóes na estrutura e organizaçào do SUS nas regióes onde resıdem as populaçóes indigenas. para propiciar essa nteoraça e o atenómento necessáno em tooos os nivers. sem discriminaçöes

$\S 3^{\circ}$ As populaçoes indigenas devem ter acesso garantido zo SUS, em âmbito local, regional e de centros especializados, de kordo com suas necessidades, compreendendo a atenção primária, secundária e terciária à saúde.

Art 19 - H. As populaçoes indigenas teräo direto a participar dos organismos colegiados de formulação, acompanhamento !avalıação das politicas de saúde, tais como o Conselho Nacional de Saúde e os Conselhos Estaduais e Municipais de Saúde, pando for o caso.

Art $2^{\circ}$ O Poder Executivo regulamentara esta Lei no prazo de noventa dias.

Art $3^{\circ}$ Esta Lei entra em vigor na data de sua publicação

Brasilia. 23 de setembro de 1999; $178^{\circ}$ da Independência e $111 .^{\circ}$ da República.

\section{FERNANDO HENRIQUE CARDOSO}

losé Serra - Ministro da Saúde 


\section{Anexo 4- Quadro de Profissionais dos Distritos Sanitários Especiais Indígenas no Brasil, 2000}

\begin{tabular}{lllllll}
\hline Profissional & Meta 2002 & $\begin{array}{l}\text { Situação } \\
2000\end{array}$ & Contratados & $\%$ & Treinados & $\%$ \\
Médicos & 232 & 182 & 138 & 75 & 84 & 46 \\
Enfermeiro & 317 & 252 & 223 & 88 & 139 & 55 \\
Dentistas & 162 & 120 & 104 & 86 & 56 & 46 \\
Aux.enf. & 889 & 732 & 708 & 96 & 436 & 59 \\
AIS* & 2644 & 2311 & 1545 & 66 & 439 & 18 \\
AISAN** & 320 & 161 & 16 & 9 & 0 & - \\
Outros & 897 & 825 & 719 & 87 & 185 & 22 \\
Total & 5471 & 4583 & 3437 & 74 & 1339 & 29 \\
\hline
\end{tabular}

Fonte: Adaptado de Pellegrini, M. Povos Indígenas e a conquista da cidadania no campo da saúde. In: Povos Indígenas no Brasil 1996/2000. Instituto Sócio Ambiental.

*AIS- agente indigena de saúde

**AISAM- agente indígena de saneamento 


\section{Anexo 5 Relatórios utilizados como fontes documentais. USMA/UNIFESP.}

\{EPM\} Escola Paulista de Medicina. Programa de Saúde no

Xingu, 1987 \{EPM\} Escola Paulista de Medicina. Programa de Saúde no

\{USMA\} Unidade de Saúde e Meio Ambiente. Universidade Federal de São Paulo. Relatório de Atividades. 1991

\{USMA\} Unidade de Saúde e Meio Ambiente. Universidade Federal de São Paulo. Relatório de Atividades. 1992

\{USMA\} Unidade de Saúde e Meio Ambiente. Universidade Federal de São Paulo. Relatório de Atividades. 1993

\{USMA\} Unidade de Saúde e Meio Ambiente. Universidade Federal de São Paulo. Relatório de Atividades. 1994

\{USMA\} Unidade de Saúde e Meio Ambiente. Universidade Federal de São Paulo. Relatório de Atividades. 1995

\{USMA\} Unidade de Saúde e Meio Ambiente. Universidade Federal de São Paulo. Relatório de Atividades. 1996

\{USMA\} Unidade de Saúde e Meio Ambiente. $2^{\circ}$ Etapa de Concentração do Curso de Formação de Auxiliares de Enfermagem Indigenas. Universidade Federal de São Paulo. 1997

\{USMA\} Unidade de Saúde e Meio Ambiente. $3^{\circ}$ Etapa de Concentração do Curso de Formação de Auxiliares de Enfermagem Indigenas. Universidade Federal de São Paulo. $1998^{\mathrm{a}}$

\{USMA\} Unidade de Saúde e Meio Ambiente. Relatório de Atividades. Universidade Federal de São Paulo. 1998b

\{USMA\} Unidade de Saúde e Meio Ambiente. Universidade Federal de São Paulo. Relatório da Oficina de Trabalho. Articulando conteúdos do núcleo comum e núcleo profissionalizante. 13 a 16/3/1999. 1999a.

\{USMA\} Unidade de Saúde e Meio Ambiente. Universidade Federal de São 
Paulo. Relatório de Atividades. 1999b

\{USMA\} Unidade de Saúde e Meio Ambiente. Universidade Federal de São

Paulo. Relatório de Atividades do Curso de Formação de Auxiliares de Enfermagem Indígenas. 2000

\{USMA\} Unidade de Saúde e Meio Ambiente. Universidade Federal de São Paulo. Relatório do Curso de Agentes Indigenas de Saúde. Alto Xingu,2000

\{USMA\} Unidade de Saúde e Meio Ambiente. Universidade Federal de São Paulo. Relatório Consolidado de Supervisão. AIS e AEI. 1998-2001.

\{USMA\} Unidade de Saúde e Meio Ambiente. Universidade Federal de São Paulo. Relatório de Acompanhamento. 1998-2001. 
Anexo 6

Proposta Modular do Curso de Capacitação de Agentes Indígenas de Saúde. FUNASA, 2000. 


\begin{tabular}{|c|c|c|c|c|c|c|}
\hline ETXO TEMATICO & INTRODUTORIO & MODULO 1 & MODULO 2 & MODULO 3 & MÓDULO 4 & MÓDULO 5 \\
\hline $\begin{array}{l}\text { Percebendo } \\
\text { Nossa Realidade }\end{array}$ & $\begin{array}{l}\text { História dos povos } \\
\text { Indigenas e do Contato; } \\
\text { Território: Ocupação e } \\
\text { Transformações. }\end{array}$ & $\begin{array}{l}\text { Mudanças ambientais, } \\
\text { culturais, econômicas e } \\
\text { dos modos de viver dos } \\
\text { povos indigenas; } \\
\text { Impacto sobre o Meio } \\
\text { Ambiente e Saúde; } \\
\begin{array}{l}\text { Estratégia } \\
\text { sobrevivência dos povos } \\
\text { indigenas. }\end{array}\end{array}$ & $\begin{array}{l}\text { - Riscos da } \\
\text { intercultural; } \\
\text { Processos } \\
\text { aculturaçãoo } \\
\text { consequências } \\
\text { saúde. }\end{array}$ & $\begin{array}{l}\text { - Saúde e Meio Ambiente; } \\
\text { Mudanças culturais e nos } \\
\text { modos de vida das } \\
\text { populações indigenas; } \\
\text { Relação entre os seres } \\
\text { vivos. }\end{array}$ & 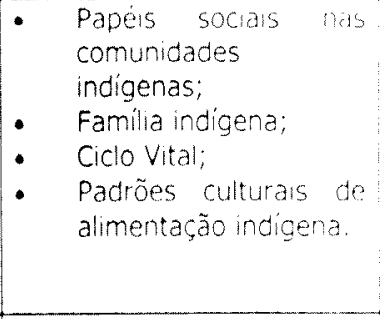 & $\begin{array}{l}\text { Mudos de vida e } \\
\text { trabaho da população } \\
\text { adulta nas comunidades } \\
\text { mdigenas: }\end{array}$ \\
\hline $\begin{array}{l}\text { Promovendo a } \\
\text { Saúde e } \\
\text { Intervindo no } \\
\text { Processo Saúde- } \\
\text { Doença }\end{array}$ & 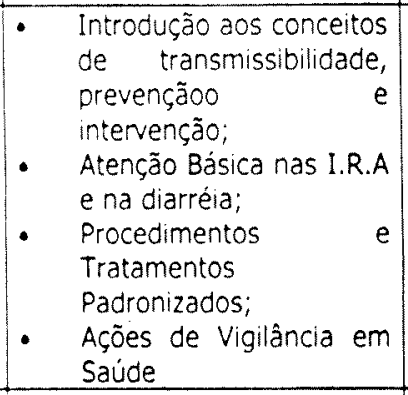 & $\begin{array}{llr}\text { - Atenção Básica em } \\
\text { Tuberculose, Malária e } \\
\text { Dengue; } \\
\text { - Controle de Endemias**; } \\
\text { Procedimentos } & \\
& \text { Tratamentos } \\
& \text { Padronizados; } \\
\text { - Ações de Vigilância em } & \\
\text { Saúde. }\end{array}$ & $\begin{array}{|lr|}\text { - Atenção Básica nas } \\
\text { DSTs/Aids, Hepatites; } \\
\text { - Alcoolismo como fator } \\
\text { de risco para as } \\
\text { DSTs/Aids; } & \\
\text { Procedimentos r e } & \\
\text { Tratamentos } & \\
\text { Padronizados; } & \\
\text { Procedimentos } & \text { de } \\
\text { Desinfeção } & \text { e } \\
\text { Esterilização; } & \\
\end{array}$ & $\begin{array}{lll}\text { - Atenção Básica r na } \\
\text { Parasitoses Digestivas e } \\
\text { Doenças de Pele; } \\
\text { Procedimentos } \\
\text { Tratamentos } \\
\text { Padronizados; } \\
\text { - Noções básicas de Higiene } \\
\text { e Saneamento; } \\
\text { - Ações de Vigilância em } \\
\text { Saúde. }\end{array}$ & $\begin{array}{l}\text { - Atencão Básica à } \\
\text { mulher e criança } \\
\text { indigena; } \\
\text { Procedimentos e } \\
\text { Tratamentos } \\
\text { Padronizados; } \\
\text { - Imunização em àreas } \\
\text { indígenas; } \\
\text { Açóes Básicas de } \\
\text { Saúde Bucal. }\end{array}$ & $\begin{array}{l}\text { - Suporte Básico de vida; } \\
\text { Atendimento de } \\
\text { urgencias a } \\
\text { emergéncias; } \\
\text { Agravos de saúde do } \\
\text { adulto indigena } \\
\text { decorrentes das } \\
\text { mudanças culturais e da } \\
\text { alimentação. }\end{array}$ \\
\hline $\begin{array}{l}\text { Conhecendo e } \\
\text { Organizando os } \\
\text { Serviços de } \\
\text { Saúde }\end{array}$ & 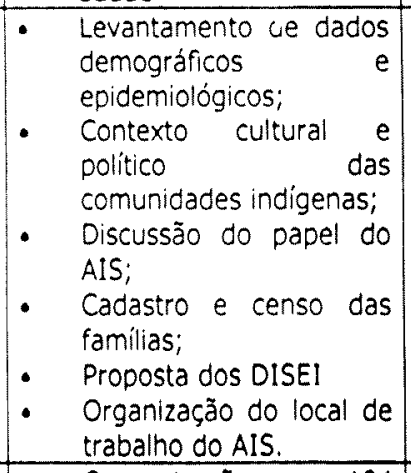 & $\begin{array}{ll}\text { - } & \text { Discussão do papel do } \\
\text { - } & \text { AIS; } \\
\text { Importância da Vigilância } \\
\text { - } \\
\text { Ações de de controle de } \\
\text { endemias; } \\
\text { - Organização do DISEI; } \\
\text { Sistema de Informação em } \\
\text { Saúde nos DISEls (SIASI). }\end{array}$ & $\begin{array}{l}\text { - Sistema de Referência } \\
\text { e Contra-Referência; } \\
\text { Notificação de } \\
\text { doenças; } \\
\text { Trabalho na Casa de } \\
\text { Saúde do Índio; } \\
\text { - Técnicas Educativas; }\end{array}$ & $\begin{array}{l}\text { Processo de Trabalho; } \\
\text { - Acões Educativas; } \\
\text { Vigilancla do Meio } \\
\text { Ambiente. }\end{array}$ & 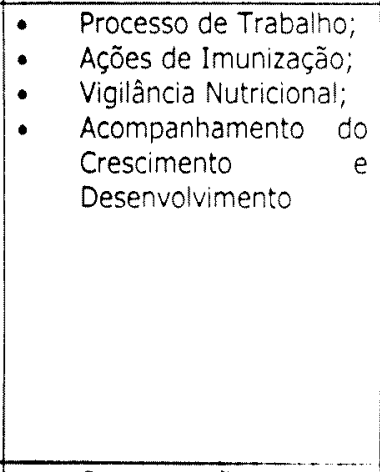 & $\begin{array}{l}\text { - Educação em Saúde; } \\
\text { - } \quad \text { Remiláncia de Agravos; } \\
\text { - Sistema de Pacientes; } \\
\text { Contra-Referênciencia e } \\
\text { - Avaliação dos Serviços } \\
\text { de Saúde. }\end{array}$ \\
\hline
\end{tabular}

* AS DOENÇAS ENDEMICAS SERAO TRABALHADAS DE ACORdo COM O PERFIL EPIDEMIOLÓgICO REgONAL, POR EXEMPLO, CHAGAS, TRACOMA, ONCOCERCOSE, LEISHMANIOSE VISCERAL 


\section{Anexo 7}

Curso de Formação em Auxiliar de enfermagem para indígenas.ETS/MS, 1999 = 2000. 


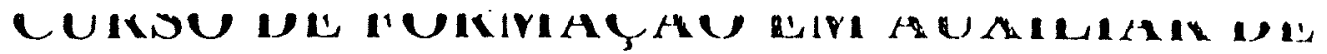 ENFERMAGEM PARA INDÍGENAS}

\section{I - CONTEXTO}

Ihi varios anos tem se discutido a nivel nacional a formasão do Agent: Indigena de Salude.

As Conferencias Nacionais de Saude Indigena cnfatizam esse tema : preconizam que o Agente Indigena de Saude seja um prolissional reconlecido e inserid, no Sistema Oficial de Sánde.

A partir de 1996 a Fundação Nacional de Saúde promoveu oficinas Macı's Regionais com o objetivo de disculir e aprescntar propostas para uma formaçã, profissional reconhecida c inserida no mercado de trabalho.

Em Mato Grosso após prèvio levantamento constatou-se a existência d:ı Agente Indigena de Saúde em praticamente todas as etnias, porém com nivveis diferentı $s$ de capacitação e inserção. Observou-se que a maioria recebeu capacitação através de cursos e pontuais treinamentos proporcionados por instituições govemamentais e nâs governamentais; quanto a sua inscrção a maioria trabalha de forma voluntária, alguı $S$ contratados pela FUNAI c oulros pelos municipios, porém lodos de forma distorcida, à margem do Sistema Olicial de Sainde.

Visando a implementação do Sub-sislema de Saude Indígena e a criaças dos Distritos Sanitários Especiais Indigenas, o Estado de Mato Grosso, dentro di's atribuições que the são conferidas pelo SUS, entre outras ações preocupou-se com o aspecto de formação do Agente Indigena de Saúde, de maneira a inseri-lo em una categoria profissional reconhecida, dotando-o de couhecimento para extensão ca cobertura das ações de saúde nas comunidades, numa proposta de ação conjunta co:ı equipes multiprofissionais, numa realidade geográfica e culturalmente diferenciada.

Frente a essa necessidade e atendendo às reivindicaçôes advindas dis lideranças e dos agentes indigenas para definição de seu papel, o Estado desencadec " 
vánios cncontros locais, regionais e estaduais, nas quais cristalizou-se a proposta de formaçãn de Auxiliares de Enfermagem lndigena.

A pantir dessa delinição foram apontados os segunines criterios pana a selecân, dos alunos

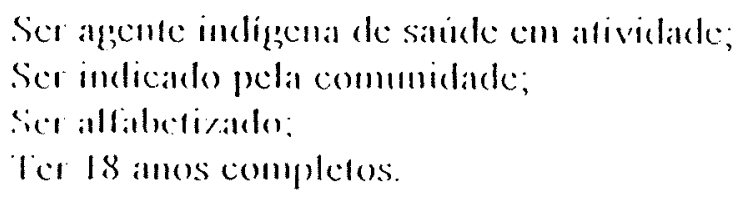

$\wedge$ liscola Ténica de Sinde, SI:S/MT assumiu a realizarão do Curso de Auxilia, de Infermagem Indigena allaves de uma equipe mulliprolissional e de encaminhar o processo de autorização e reconhecimcnlo do C'urso ans ógãos competcntes.

O curso foi iniciado em janciro de 1998 , sendo execulado $\mathrm{cm} 05$ (cinco) regiócs do lislado:

- Tangana da Serra: trinta alunos de oito conias - Nambiquara, Llmulina, Sabanc, Kayabi, Paresi, Cinta Larga, Lanlxce Rikbakısa.

- Rondonópolis: vinte e três alunos de duas chnials - Bororo e Bakani.

- Barra do Gargas/ Nova Xavantina - lrinta alumos da chnia Xavante.

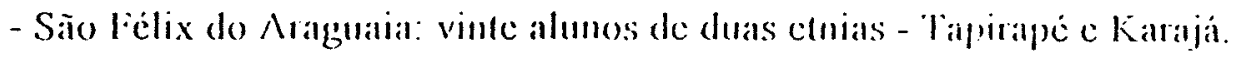

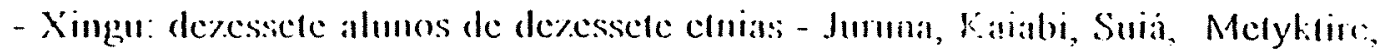
Ikpeng. Waura, Cuicuro, Kamayuri, Meinaco, Yanvalapili, Trumai, Mvedi, Nalingua, Malipu, kialapalo, Tapayuma.

O Curso foi previsto scr realizado em od (quatro) etapas de concentração' perfazendo carga horária de 800 horas mas quais scriam tabalhados os conteúdos teórico:/ cientilicos/ práticos e 04 (quatro) elapas de dispersão ${ }^{2}$, per fazendo carga horária de 640 horas nas quais os alunos em seus locais de trabalho (aldcias ou postos indigenas) desenvolverian sua prática sob supervisio das professores aproximando teoria/ pratica elaborando noves conliccincntos.

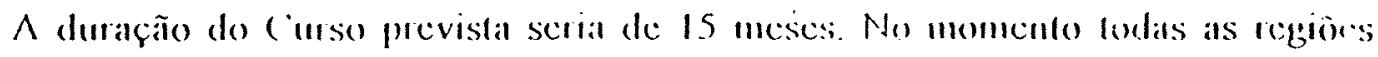
cstão tcrminando a 2. " clapa.

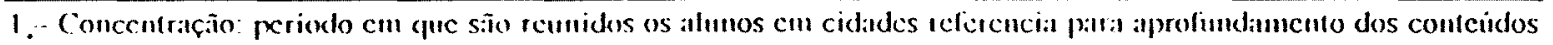
renicos/ciontilicos.

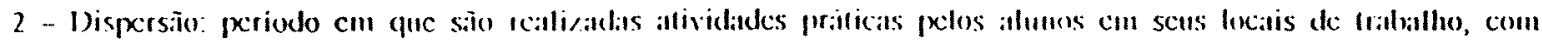
supcrvision dos instrutores. 


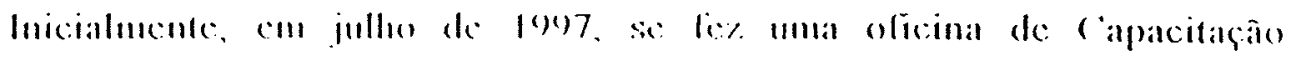
Pedagogica, com dumag̃a de 80 homas, para preparan o: professores nat metodologia proposta.

Cada ctapa é precedida de uma olicina Avaliaşão e Mlancjamcnto para o: professores duante a qual se avalia o processo e colctivamente se constrói " planejamento da etapa subsequente, considerando o perfil cpidemiológico c a: especificidades geograticas e culturais de cada regiâo.

O Consclho Estadual de Educação, analizando o processo de aprovação reconhecimento do Curso deparon com a siluação da escolanidade da clientel: constatando a necessidade de complementação da cscolaridade em nivel de Ensin: Fundamental, a fim de poder certificá-los como prolissionais.

$\Lambda$ alual proposta da liscola Técnica de Sande/ SLS-MT é ampliar a duraçã do Curso até julho do ano 2000 , acrescentando mais 3 chapas e introduzindo a partir \& 3." etapa o cusino fundamental, de forma integrada ao cnsino profissionalizante, atravi: de professorcs habilitados para essa função. 
A ampliação do curso se lim cutâo necessinia devido à exigência da formação do $1^{\circ}$ Gian, incluindo-se 800 horas de disciplinas do ensino fundamental. En função da metodologia adotada, os contendos do cusino fundamental devem sor inseridos de forma integrada ao consino prolissionalizante, o que obriga a manutenção des contratos da equipe cnvolvida até o limal do processo; alcm da contralação eventual de prolessores especialistas mas disciplinas especilicas.

O acréscimo da carga horaria lem de ser dishibuido enlec as clapas de curso, acarreando no acrescimo de mais 03 chapas, alem das 0.1 inicialmente previstas.

A necessatia intercalição cutre as lases de concentração e de dispersão len a

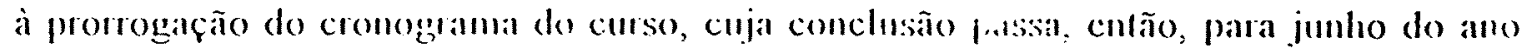
2000 .

Legalmente os minimos profissionalizantes e instrumentais contidos nesta proposta são os mesmos decrminados pelas Resoluções do Conselho Federal (ie Educação (CFI:) N. "s 07 c 08 de 1997 para a área de cnfermagem e na via supletiva de ensino, conforme o Parecer 699/72 do Clil:

A nova L.DH do cosino, promulgada cm 1996 expandiu e regulamentou is possibilidades da educação profissional, viabilizando a implantação de outris experiencias de prolissionalização gue no contexto do traballio em saude ocorrem deste 1982.

Para a árca de salude publica, a llexibilizaţão das modalidades de formaçấo e capacilação profissional estão promovendo o acesso à clucação c consegucntemente :o trabalho qualificado em muitas localidades distantes de centros urbanos, ou com caracteristicas sócio culfurais cspecificas, como assculamcntos rumis c commidadis indigcnas, uma inovação) guc ora se apresculat. 
III-OB.JIEIVOS

1. Polissionalizan 120 Apentes de Sande Indigenas de 30 etnias do Lestado de Malo (irosso, cun Anxiliar de linfermagem;

2. Capacital os alunos para infervir politica e administantivancnte no pocesso de lmplantação dos distrilos sambários especiais indigenas;

3. Implementar processos de melhoria de qualidade dos serviçes desempenhados pelos alunos; 
A cstratégia proposta visa formar anxiliares de entemagem indigenas ao mesmo tempo em que se estruturam os DStís. Para tanto scrá utilizado um modelo de curso com as seguintes caracteristicas:

- cxecução curricular descentralizada, vollada para as caracteristicas da clientela em questão (indios adultos, já trabalhando em suas comunidades como agentes de saúde, sem o grau de escolaridade exigido como condição de cntrada pele ensino regular) e que possibilite sua formação $\mathrm{cm}$ seu próprio local de trabalho, sem (ue seja necessário scu alastamento por longos periodos, o que acarrctaria cm prejuizos aos usuários pela interrupção dos serviços prestados. Ao mesmo lempo, a formação centrada no local de trabalho, além de poder traballar a realidade concreta dos sevviços, $1 \mathrm{~cm}$ a função de organiza-los dumante o processo de fomação:

- desenvolvimento de oficinas de capacitação lécnica e pedagógica para os instrutores/supervisores;

- utilização de metodologia que privilegia a integracão cnsino-laaballo c;

- claboração de un curriculo integrado especilico que viabilize esse processo com essas caracteristicas:

- Comalização da articulação cutre os espaços de ensino e traballı pela integração interinstitucional de órgàos responsáveis pela cducação e saude indigena no estado de Mato Grosso;

- intcgração dos contcidos programáticos cm cinco allcas curriculares e sete módulos, abordando os principais aspectos ligados ao processo saúde/doenga das comunidades indigenas. 
Fetaria de Estado da ile

da Técnica de Saúde ISaúde do Índio AI - ADR's Cuiabá,
u, Tangará da
a, Barra do Garças,
Xavantina,
uaia, Colíder er
's de Rondonópolis,
a, Vilhena e Água

- Fazer a coordenaciáo tecanica e pedagógica do curso;

- Realizar a marricula dos alumes.

- Lomecer o material e instumental básico;

- Dazer a escrituraciano escolar e expedição dos documentos de conclus io dos cursos;

- Cumprir as resoluçoes dos comselhos liederal c listadual de I:ducas io concenentes ao ensino prolissionalizante de saude, atim de resguarr at as responsabilidades da IETS/MT nos cursos por ela administrar is perante esses ógãos de liscalização;

- Olicializar o Curso junto a SIID)(IC e CEE;

- Disponibilizar recursos humanos para a viabilização das ações

- Disponibilizar profissionais para compor as equipes le professores/supervisores;

- Coordenação cxeculiva do Curso;

- Dar apoio técnico na área de saude indigena;

- Garantir o cumprimento do cronograma do curso quando houver atr: io no repasse de recursos do i'ROI)I: $\Lambda$ GRO

- Acompanhamento do desenvolvimento do Projeto;

- Ceder estruluras de saude existentes nas áreas indigenas e 1 as relcrencias (Casa do indio) para estágios dos cursistas;

- liacilitar o acesso dos consultores nas áreas indigenas enr que ie descnvolverão os estágios;

- Designar con cada região um funcionário administrativo para atı ar junto aos consultores;

- Liberar a enfermeira de Barra do Garças, o antropólogo de Cuiabá e técnica de laboratório de São Íélix;

- Fornecer apoio logistico;

- Viabilizar cstrutura lisica nas aldcias para o bom desenvolvimento lo Projeto.

- Participar da Coordenação Interinstitucional;

- Coordenar as atividades relativas ao ensino findanental;

- Colaborar na scleção c capacilação dos professores que irão minist ar as disciplinas do ensino fundamental

- Desenvolver o curso na região do Xingu;

FESP/EPM
ade de Saúde e Neio
iente

COSAI-I)I

III / CIR-CiO
- Prestar assessoria nas diferentes etapas do curso sempre que solicita(');

- Realizar a captação e scleção de recursos humanos para compor as equipes de professores/supcrvisores da região do Xingú.

- Participar da Coordenação Interinstitucional;

- Colaborar na capaciação dos instrutores e professores;

- Oferecer campor de estagio em suas unidades aos alunos, com pre io plancjamento sempre acompantados pelos professores do Projeto;

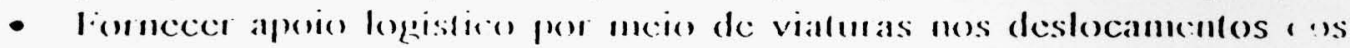
prolessores nas elapas de dispersão, de acordo com planejamer lo peivio;

- Repasse dos dados de produçãa cpidemiologicos;

- Aquisigano de material permanconte e de consumo para equipar as unidades de sabde das aldeias, mediante planejamento prévio;

- Apuisição de aparellos de rádio-comunicapáo para facilitar o traba io de orientação e supervisão 
1. Quadro I - Demosntrativo financeiro da primcira fase do Projeco Xamã, financiado pela Secretaria Estadual da Saúde do Estado de Mato Grosso (SES/MT) e PRODEAGRO, período de janciro/98. a julho/99.

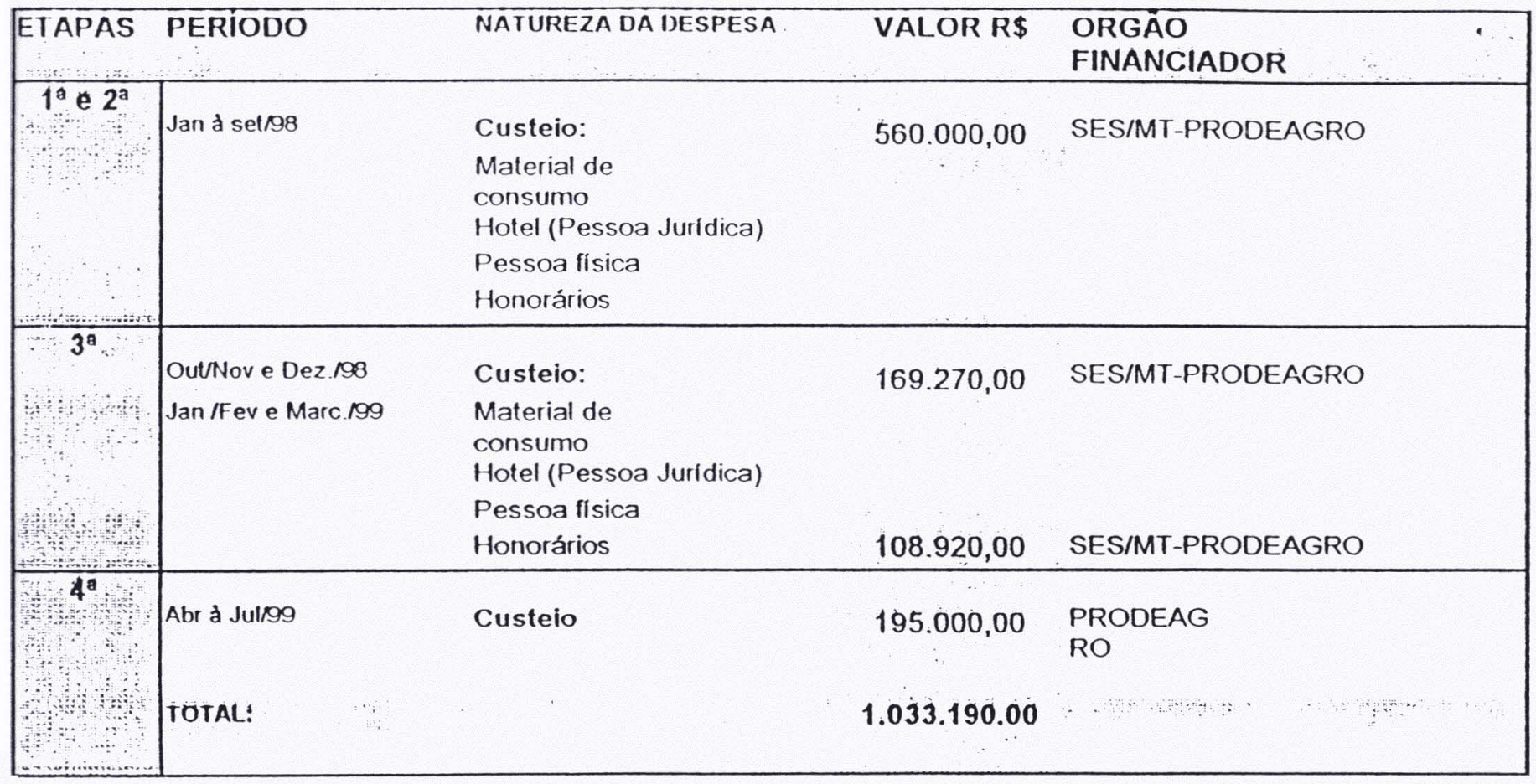


2. Quadro I - Proposta financeira da segunda fase do Projeto Xamã, a ser financiada pela Secretaria Estadual da Saúde do Estado de Mato Grosso (SES/MT) e PRODEAGRO, periodo de janciro/98. a julho/99.

\begin{tabular}{|c|c|c|c|c|c|}
\hline \multicolumn{3}{|c|}{ 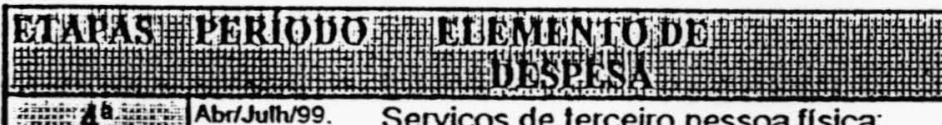 } & \multicolumn{3}{|c|}{ 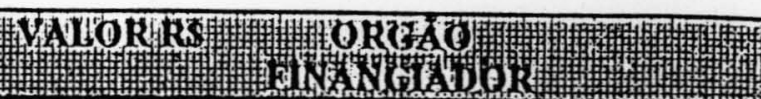 } \\
\hline 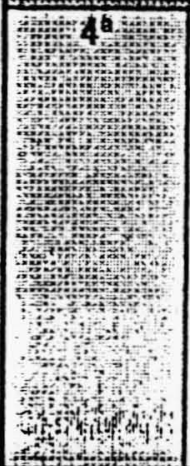 & Abrisulh/99. & $\begin{array}{l}\text { Serviços de terceiro pessoa física: } \\
\text { Serviços de terceiro pessoa juridica: } \\
\text { Material de consumo: } \\
\text { Diárias: } \\
\text { Passagem: } \\
\text { Totál: }\end{array}$ & $\begin{array}{r}144.000,00 \\
32.830,80 \\
176.000 .80\end{array}$ & $\begin{array}{l}\text { FNS/VIGI } \\
\text { SUS } \\
\text { SES/MT- } \\
\text { PRODEAGRO } \\
\text { SES/MT- } \\
\text { PRODEAGRO } \\
\text { FNS/VIGI } \\
\text { SUS } \\
\text { SES/MT- } \\
\text { PRODEAGRO }\end{array}$ & \\
\hline : & Agost/Sot' & $\begin{array}{l}\text { Serviços de terceiro pessoa fisica: } \\
\text { Serviços de terceiro pessoa jurídica: } \\
\text { Material de consumo: } \\
\text { Diárias: } \\
\text { Passagem: } \\
\text { Tótal: }\end{array}$ & $\begin{array}{r}108.000,00 \\
95.200,00 \\
44.600,00 \\
32.830,80 \\
12.000,00 \\
292.630 .80\end{array}$ & $\begin{array}{l}\text { FNS/VIGI } \\
\text { SUS }\end{array}$ & \\
\hline Hon & Nov Jez $/ 99$ & $\begin{array}{l}\text { Serviços de terceiro pessoa física: } \\
\text { Serviços de terceiro pessoa juridica: } \\
\text { Material de consumo: } \\
\text { Diárias: } \\
\text { Passagem: } \\
\text { Tolatal: }\end{array}$ & $\begin{array}{r}144.000,00 \\
109.700,00 \\
35.100,00 \\
32.830,80 \\
25.000,00 \\
346.810 .80\end{array}$ & $\begin{array}{l}\text { FNS/VIGI } \\
\text { SUS }\end{array}$ & \\
\hline 7 & Jan/F ev/Mar & $\begin{array}{l}\text { Serviços de terceiro pessoa física: } \\
\text { Serviços de terceiro pessoa juridica: } \\
\text { Material de consumo: } \\
\text { Diárias: } \\
\text { Passagem: } \\
\text { Total: }\end{array}$ & \begin{tabular}{r|}
$144.000,00$ \\
132.700 .00 \\
$46.280,00$ \\
$32.830,80$ \\
38.000 .00 \\
393.810 .80 \\
\end{tabular} & $\begin{array}{l}\text { FNS/VIGI } \\
\text { SUS }\end{array}$ & \\
\hline \multicolumn{6}{|c|}{ 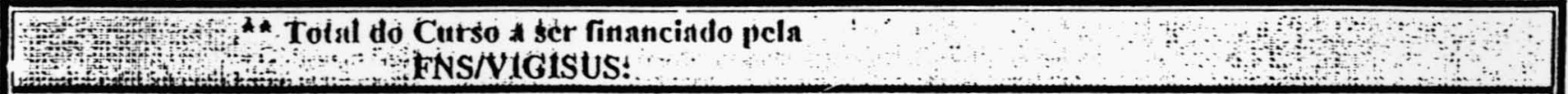 } \\
\hline & $\begin{array}{l}\text { Serviços d } \\
\text { Serviços de } \\
\text { Material de } \\
\text { Diárias: } \\
\text { Passagem }\end{array}$ & $\begin{array}{l}\text { e terceiro pessoa fisica: } \\
\text { terceiro pessoa jurldica: } \\
\text { consumo: }\end{array}$ & $\begin{array}{r}540.000,00 \\
132.700,00 \\
46.280 .00 \\
135.000,00 \\
132.980,00\end{array}$ & & \\
\hline 4 & Total: & & $1.526 .960,00$ & & \\
\hline
\end{tabular}


Anexo 8

Perfil dos AIS, Xingu 
Prestar assistência à saúde em nível básico, desenvolvendo prioritariamente ações de vigilância à saúde, prevenção e controle de doenças por meio de visitas domiciliares, atividades educativas e assistência primária de saúde, sempre supervisionados por profissionais de saúde capacitados para a função.

\section{Requisitos:}

- ser indicado pela comunidade

- residir na área de atuação

- pertencer à sociedade em que vai atuar

- não ter outro vínculo empregatício

- ter um bom relacionamento com a comunidade e ser alfabetizado em português

- ter idade mínima de 18 anos

- manifestar interesse, aptidão e responsabilidade para o trabalho em saúde

Competências elaboradas pelo Grupo de Trabalho do DEOPE/COSAI, 1999

\begin{tabular}{|l|l|}
\hline Competência 1 & $\begin{array}{l}\text { Elaborar seu plano de trabalho com base na } \\
\text { identificação das necessidades relacionadas ao } \\
\text { processo saúde/doença, de acordo com o contexto } \\
\text { de sua atuação }\end{array}$ \\
\hline Competência 2 & $\begin{array}{l}\text { Prestar cuidados básicos de recuperação e } \\
\text { reabilitação, indicados para as diferentes fases do } \\
\text { ciclo da vida }\end{array}$ \\
\hline Competência 3 & $\begin{array}{l}\text { Realizar ações de promoção da saúde, que resultem } \\
\text { na melhoria da qualidade de vida, utilizando os } \\
\text { recursos dos serviços e práticas existentes, de forma } \\
\text { articulada com recursos de outros setores. }\end{array}$ \\
\hline Competência 4 & $\begin{array}{l}\text { Empreender ações básicas de atenção a saúde } \\
\text { individual, familiar e coletiva, com ênfase na } \\
\text { prevença e controle das enfermidades } \\
\text { transmissiveis e no controle do meio ambiente }\end{array}$ \\
\hline Competência 5 & $\begin{array}{l}\text { Gerenciar seu trabalho, atuando individualmente ou } \\
\text { em equipe, acompanhando, avaliando e } \\
\text { reorientando o processo de prestação de cuidados } \\
\text { sob sua responsabilidade }\end{array}$ \\
\hline Competência 6 & $\begin{array}{l}\text { Conhecer a política nacional de saúde e os aspectos } \\
\text { pertinentes a saúde indígena }\end{array}$ \\
\hline
\end{tabular}




\section{Supervisão de AEI e AIS - Pólo Diauarum (20/02/01 a 22/03/01)}

\section{AEI Puran (PI Diauraum)}

- é bastante interessado e disponivel, porém apresenta momentos, principalmente na UBS do PI Diauarum, em que faz o atendimento de forma rápida e desatenta; mantém ordem e limpeza no local de trabalho, realiza corretamente as técnicas básicas de Enfermagem como preparo de medicações, administração via oral e intramuscular, nebulização, verificação de sinais vitais.

- muitas vezes não realiza um exame físico mais completo, subestimando sinais e sintomas importantes.

- durante as viagens de trabalho desempenha muito bem sua função, é atencioso e cordial comras comunidades, tem iniciativa e interesse durante o trabalho. Sabe trabalhar em equipe, é aberto a sugestões e ao processo de supervisão.

\section{AEI Preayup (aldeia Cururu)}

- mostrou-se bastante interessado e atuante quanto às atividades propostas para o dia de trabalho;

- seu caderno de acompanhamento de peso e altura é um dos mais completos, realiza os registros mensalmthte e de maneira bastante organizada;

- mantém a ordem e limpeza na UBS;

- conhece bem a comunidade e os casos de saúde;

- ele sugere a inclusão no relatório mensal da aldeia um impresso para acompanhamento de gestantes e o item inalação no levantamento do número de procedimentos.

\section{AEI Yefuká (aldeia Capivara)}

- possui rapidez para o aprendizado, é perspicaz, tem raciocinio investigativo e características de liderança;

- possui dúvidas relacionadas a realização do gráfico de peso e altura, e durante o treinamento para a realização deste, mostrou-se um tanto disperso, desatento e resistente ao processo de supervisão;

- realiza a recepção e atendimento dos pacientes de forma um pouco fria;

- necessita de melhorias quanto a ordem e limpeza da UBS;

- sugiro uma supervisão direcionada para o reforço de suas características fortes, porém buscando maior consciência de seu papel como referência em saúde para a comunidade, desenvolvendo para isso não só aspectos técnicos como humanos.

\section{AEI Yawot (aldeia Capivara)}

- é cordial com a comunidade, disposto e prestativo durante o trabalho e aberto ao processo de supervisão

- possui dificuldades para realização do gráfico de peso e altura, também ficou disperso durante o treinamento deste;

- a prática de ordem e limpeza da UBS é deficiente; 


\section{AEI Poikô ( aldeia Ricô)}

- é atencioso com a comunidade e equipe de saúde, trabalha bem em equipe, possui iniciativa, colaboração e disposição para o trabalho proposto; - realiza um bom registro dos dados, conhece bem a comunidade e casos de doença;

- possuia algumas dificuldades quanto a realização do gráfico de peso e altura, porém através de empenho e atenção ao fim do dia estava confeccionando o gráfico com muito mais facilidade.

\section{AEl Tarei (aldeia Tuiararé)}

- é atencioso, prestativo e comprometido com a comunidade e o trabalho;

- tem facilidade de aprendizado, é muito interessado, fazendo perguntas e buscando resolver suas dúvidas

- mantém limpa e organizada a UBS;

- necessita conhecer um pouco melhor a comunidade e os casos de doença.

\section{AEI Tamarikó (aldeia Tuba-Tuba)}

- é interessado, questionador, um pouco resistente ao processo de supervisão, principalmente nos momentos em que necessitava de correçōes e sugestōes;

- tem dificuldade para realização do gráfico de peso e altura, cálculos matemáticos e língua portuguesa;

- o caderno de atendimento estava desorganizado e incompleto, assim como a UBS necessita de maior organização e limpeza.

\section{AIS Mazinho (PI Diauarum)}

- é interessado, atencioso, porém seu humor inconstante reflete na qualidade da assistência.

- realiza bem o preparo e administração de medicamentos e as anotaçōes no livro de atendimento;

- tem dificuldades para ausculta pulmonar e verificação de pressão arterial.

\section{AIS Diuwaiú (aldeia Sobradinho)}

- necessidade de um treinamento relativo ao tema IRA, pois o agente já realiza os esquemas terapêuticos padronizados pela questão da distância da aldeia ao pólo.

- possui algumas dificuldades quanto ao preenchimento do relatório mensal, porém aprendeu fácil quando realizamos juntos

- é interessado, participativo durante o trabalho, organizado e conhece bem a comunidade. 


\section{AEI Tafuraki (aldeia Nafukuá)}

- conhece bem a comunidade, tem características de liderança e facilidade de aprendizado;

- demonstrou certa dificuldade em trabalhar em equipe e resistência quanto à supervisão, treinamento e sugestões que Ihe eram feitas.

\section{AIS Apayupi (aldeia Waurá)}

- pela questão do tempo curto de permanência na aldeia, não pode ser realizada uma observação mais completa, porém o agente mostrou-se bastante interessado e muito ansioso frente a um caso de desidratação e diarréia; parece ter dificuldade em avaliar a gravidade dos casos subestimando ou superestimando-os.

\section{AIS Joi e Ayatu (aldeia Kuikuro)}

- ambos estavam bastante interessados e receptivos; foi observada uma certa deficiência quanto ao acompanhamento de gestantes; não foi possivel realizar uma supervisāo mais detalhada pela quantidade de atividades realizadas durante o periodo.

\section{AIS Hakamu (aldeia Afukuri)}

- apesar do pouco tempo de permanência na aldeia, foi observado interesse, bom conhecimento da comunidade e dos pacientes, e avaliação ponderada dos casos de doença.

\section{AIS Cláudio (aldeia Tanguro)}

- dificuldade de compreensão, fala e escrita do português

- dificuldade para verificação de respiração

- dificuldade para ausculta pulmonar

- realiza medicação IM, porém não houve oportunidade de avaliação do procedimento

- dificuldade para cálculo de medicação e horários de administraçāo

- medicalização sem avaliação criteriosa; realiza diagnósticos precipitados

- caderno de atendimento desorganizado, não anota diariamente os pacientes em tratamento

- dificuldade de exame e avaliação de crianças pequenas

- é cordial com a comunidade, não realiza visita domiciliária

- não participa ativamente do trabalho quando outro profissional se encontra na aldeia.

- Sugiro antes mesmo de um reforço de aspectos técnicos, um trabalho com o agente de estímulo, motivação e conscientização da importância do seu papel e da sua responsabilidade sobre sua comunidade, de forma que ele não desanime perante suas dificuldades, mas que sinta-se alguém importante para sua comunidade, o que facilitará o processo de aprendizado. 
AIS Kumaiu e Kıllikuya (aldeia Mehinako)

- são muito interessados, questionam bastante e possuem muita vontade de aprender

- realizamos treinamento para mensuração de pressão arterial, temperatura e frequêencia respiratória e realização do relatório mensal, que eram dificuldades de ambos

AIS Kuaray e Tawaná (aldeia Aweti)

- a ordem e limpeza da UBS é excelente, são interessados, porém o AIS Tawaná demonstrou-se mais disperso)

- o caderno de atendimento é organizado, porém possuem dificuldades para compreensão dos horários de medicamentos e nomenclatura dos horários após o meio-dia, sendo realizado um treinamento sobre as horas dos dia e o intervalo entre as doses de medicação, com bons resultados. Realizamos também um treinamento para mensuração de pressão arterial, temperatura e freqüència respiratória. 
focal e data: Aldeia Cuicuro. 19 e 20 de Agosto de 2000.

arga horária: 12 horas.

Irividades: Atendimento e discussão de casos clinicos, com ènfase na anamnese e exame físico e realização da conduta prescrita pelo médico.

upervisor. Eduardo Nozaki Canó (médico)

hunos: Talico Cuicuro (Auxiliar de Enfermagem Indigena)

Joy Cuicuro (Agente Indigena de Saude)

Ayatu Cuicuro (Agente Indigena de Saúde)

Foi realizado a supervisão dos alunos supracitados na própria aldeia onde residem e labalham. Os alunos acompanhados do supervisor percorreram todas as casas. Os casos eram assados pelo aluno que primeiro assistiu o doente; em sendo caso novo, um dos alunos era scolhido para fazer a anamnese, o exame físico e dar sua hipótese diagnóstica e condutas ertinentes. Após o aluno passar o caso, o supervisor realizava um interrogatório complementar, uscando esclarecer pontos duvidosos da história e um novo exame. Caso houvesse algum sinal ropedêutico interessante, era mostrado a todos os alunos. Finalmente havia a discussão do caso e ealizado a conduta prescrita. A relação dos pacientes atendidos, com discriminação de sexo, idade, lpótese diagnóstica e conduta está axexada a este relatório.

\section{alico Cuicuro}

Talico referiu ter dificuldade em examinar crianças, particularmente para determinar a reqüência respiratória (principalmente quando estão chorando). Não foi possível determinar se ele fazia certo ou não, devido ou pequeno número de crianças com quadro pulmonar. Casos não luito complexos de pacientes adultos (dor de dente, mastite, infecção urinária) conduz bem. Tem inda deficiência para obter um história completa (falta por exemplo: tempo de evolução da doença, Denças pregressas...). Tem ausculta pulmonar boa, mas não realiza ausculta cardíaca ou palpação e abdômen. Aplica corretamente injeções intramuscular, embora com alguma lentidão. O problema ue mais me chamou a atenção foi em relação ao descuido com bio-segurança: cuidados com ontaminação de "ranhadeiras", cuidados com materiais pérfuro-cortantes e destino do lixo ontaminado.

\section{by Cuicuro e Ayatu Cuicuro}

Joy referiu ter dificuldade em examinar doentes em geral (adultos e crianças), rincipalmente em relação a propedêutica pulmonar. Administra corretamente medicaçôes Itramuscular. Tem ainda algumas deficiências para passar os casos.

Ayatu diz ter muitas dúvidas, particularmente em relações a condutas. Embora não tenha llministrado nenhuma medicação intramuscular, apontou corretamente seu local de aplicação e a icnica correta de fazê-lo. Sabe como é o esquema A. Demonstra interesse em aprender mais.

Infelizmente não foi possível determinar com acurácia o conhecimento técnico e teórico estes agentes de saúde, pois foi dado ênfase à supervisão do aluno de auxiliar de enfermagem.

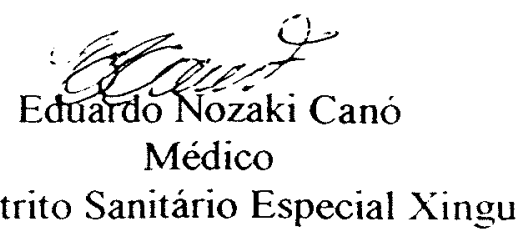


Anexo 9

Perfil dos AISB do Xingu. 
Nome: Managu Txicão

Local de nascimento:
Aldeia Moygu

Data de nascimento:

1- Quem alfabetizou você? Onde você estudou?

Foi meu primo Yambra quem me alfabetizou. Eu comecei a estudar, ler e escrever aqui no Posto Pavuru.

2- Por que você resolveu ser agente de saúde bucal?

Eu gostava do trabalho de dentista que eu via, eu trabalhava aqui no Parque, eu gostava muito mais, por isso eu escolhi ser agente de saúde bucal e a comunidade também me escolheu.

\section{3- Quem ensinou esse trabalho para você?}

Foram Biral e Estela que me ensinaram primeiro, até hoje eles estão ensinando.

4- Como é o seu trabalho na comunidade? Você espera as pessoas procurarem o seu serviço ou é você quem chama o pessoal para ser atendido?

$O$ meu trabalho vai sempre melhor, até hoje a comunidade me procura. Eles estão acostumados com o meu trabalho, eles vem sozinhos, eu vou atrás da pessoa que nunca tratou dente.

5- Você atende outras aldeias?

Eu atendo outras aldeias da abrangência do PI Pavuru e outras aldeias que não são da abrangência do Pavuru.

6- Você faz algum trabalho junto ao professor da sua aldeia? Conte como é. Nós damos saneamento e higiene para os alunos junto com os professores. damos aulas de escovação, cuidar dos dentes e da saúde em geral.

7- O que você acha mais importante no seu trabalho?

Eu acho esse trabalho muito importante, por isso eu levar para frente.

8- $O$ que você acha difícil nesse trabalho?

Extração de dentes porque nós agentes de saúde bucal não vamos extrair dente. Por isso nós queremos treinar junto com profissional. 
9- $O$ que a comunidade acha do seu trabalho?

A comunidade acha meu trabalho muito legal, eles querem que eu aprenda mais para cuidar e ajudar muito mais.

10- O que o cacique acha do seu trabalho?

O cacique acha meu trabalho legal, ele pensa que o meu trabalho é de dentista profissional.

11- Como você acha que pode melhorar o seu trabalho?

Lideranças e comunidades xinguanas têm que ver o trabalho do dentista porque esse trabalho é muito importante e é uma parte da saúde também. Toda vez que as lideranças fazem reunião, não lembram do dentista, eles deixam por fora e não ligam, por isso epidemia de comunidade que provoca cárie no dente que não melhora no Xingu. Todas as lideranças têm que acreditar no trabalho do agente de saúde bucal, como eles estão acreditando no trabalho do agente de saúde. Vamos melhorar e acreditar no nosso trabalho.

\section{2- Você participou de algum curso?}

Eu participei do sexto curso de saúde no PI Diauarum.

\section{3- Como você usa o material da COLGATE?}

EU uso COLGATE quando o dente das pessoas ficam com mau hálito, quando a pessoa não escova o dente eu mando escovar e fico orientando.

\section{4- Como você anota o seu trabalho e faz o relatório de atendimento?}

Eu anoto depois de atender a pessoa, pergunto idade, etnia local, sexo, faço relatório, quando atendi com IRM, amálgama, aplicação de flúor, perdendo dente, quanto que não perdeu.

15- Você quer dizer mais alguma coisa?

Como agora está sendo reformada a UBS, eu quero que meu consultório fique com seu consultório, equipado com seu material.

16- O que você faz com seu dinheiro?

Eu adquiro havaianas, anzol, linha, munição, sabão, pilha e pano para mulher. Eu não vou mentir, um pouquinho de comida básica. Final escova e pasta. 
Nome: Gaindoberi Kaiabi Suiá Local de nascimento: PI Diauarum Filiação: Mairawê Kaiabi e Jakita Suiá
Posto Indígena Diauarum

Data de nascimento: 11/05/73

1- Quem alfabetizou você? Onde você estudou?

Eu comecei com Mariana e depois continuei com Harue, sempre no Diauarum.

2- Por que você resolveu ser agente de saúde bucal?

Kunhãete falou para eu trabalhar com Agda e daí eu gostei. Foi em 1992, eu entrei no segundo curso de saúde da Escola Paulista, daí o pessoal me perguntou no que eu ia trabalhar. Eu disse "com Agda", dai ela aceitou.

3- Quem ensinou esse trabalho para você?

Agda começou a me ensinar no consultório e quando ela viajava eu ia junto. Quando ela atendia o pessoal eu ficava olhando e ela me explicava. Primeiro eu treinei a obturar nos modelos, depois no pessoal.

4- Como é o seu trabalho na comunidade? Você espera as pessoas procurarem o seu serviço ou é você quem chama o pessoal para ser atendido?

Eu chamo mais o pessoal Suiá, eles vem. O pessoal Kaiabi, quando eu chamo, eles não vem. $O$ pessoal Suiá também me procura, o pessoal Yudja também aparece no consultório, só crianças. Os Kaiabi vem adultos também. A maioria vem só olhar, outros quando estão sentindo alguma coisa. Quando eu era professora eu dei só uma vez aula sobre prevenção de cárie.

5- Você atende outras aldeias?

Eu já atendi no Guarujá, no Tuiararé, no Capivara, no Pequizal, no Paksamba, no Tubatuba e na aldeia Nãsepotiti junto com Biral. No Tuiararé eu trabalhei junto com Aramut, no Tubatuba junto com Dukarê. No Capivara Juwikã ficou olhando.

6- Você faz algum trabalho junto ao professor da sua aldeia? Conte como é. Nunca trabalhei com os professores.

7- O que você acha mais importante no seu trabalho? 
Eu acho mais importante obturar os denies do pessoal e depois ensinar como escovar, usar fio dental. Eu falo também sobre alimentação, cuidado com açúcar, com caramelo, precisa escovar logo depois de comer.

8- O que você acha difícil nesse trabalho?

Eu acho mais difícil fazer o pessoal entender o que eu explico, fazer o pessoal acreditar.

9- O que a comunidade acha do seu trabalho?

O pessoal gosta do meu trabalho, está bom.

10- $O$ que o cacique acha do seu trabalho?

$O$ chefe de posto acha importante o meu trabalho. Nós já combinamos viagem para atender nas aldeias, mas até agora não aconteceu por falta de gasolina.

11- Como você acha que pode melhorar o seu trabalho?

Eu acho que seria bom ter mais cursos para a gente aprender mais, ouvir mais sobre o trabalho.

12- Você participou de algum curso?

Eu participei de quase todos os cursos de saúde e alguns de educação.

13- Como você usa o material da COLGATE?

Quando as pessoas pedem eu dou, quando eu atendo, entrego também.

14- Como você anota o seu trabalho e faz o relatório de atendimento?

Eu anoto as pessoas que atendo, mas tenho dificuldade de fazer os relatórios. somar os números.

15- Você quer dizer mais alguma coisa?

Tem coisa que atrapalha o meu trabalho, que é ciúme de outras mulheres. Uma vez eu pensei em parar de trabalhar ou mudar para outra aldeia. Eu falei isso para meu pai, mas ele não falou nada. Minha mãe tem medo que possa acontecer alguma coisa ruim.

16- O que você faz com seu dinheiro?

Toda a minha familia usa o dinheiro que eu ganho. 
1- Quem alfabetizou você? Onde você estudou?

Comecei a alfabetização com a professora Janini, mas comecei a entender muito com o professor Korotowi.

2- Por que você resolveu ser agente de saúde bucal?

Eu resolvi ser dentista porque o dentista Managu saiu para estudar em Brasilia e ficou sem agente de saúde bucal. Eduardo Mattos Biral chegou e procurou agente de saúde bucal, eu perguntei se posso ser eu e ele aceitou.

\section{3- Quem ensinou esse trabalho para você?}

Eu comecei a trabalhar com Biral.

4- Como é o seu trabalho na comunidade? Você espera as pessoas procurarem o seu serviço ou é você quem chama o pessoal para ser atendido?

Eu chamo os jovens $e$ as crianças ou eles me procuram, aplico flúor, ensino a escovar e passar fio dental. As pessoas sabem que eu fico diretamente no meu consultório, eles chegam lá ou eles me procuram lá na minha casa e eu peço para eles irem no meu consultório.

5- Você atende outras aldeias?

Eu já atendi várias aldeias: Guarujá, Barranco Alto, Terra Preta, Boa Esperança, Morená e Steinen, mas eu preciso ter combustivel para atender as aldeias todo mês.

6- Você faz algum trabalho junto ao professor da sua aldeia? Conte como é. Eu já fiz meu trabalho uma vez com professor, apliquei flúor e ensinei prevenção de cárie.

7- O que você acha mais importante no seu trabalho?

Eu acho importante ajudar as comunidades para não acontecer muitos problemas nos dentes. 
8- $O$ que você acha difícil nesse trabalho?

Eu não acho nada difícil, o que eu quero eu faço do jeito que o Biral me ensinou e lembro do que ele me orientou e me ensinou.

9- O que a comunidade acha do seu trabalho?

A comunidade acha o meu trabalho muito importante, ter um agente de saúde bucal na aldeia.

10- O que o cacique acha do seu trabalho?

O cacique acha bom o meu trabalho, ele me orienta para trabalhar sério, sem fazer nada grosso nas pessoas.

11- Como você acha que pode melhorar o seu trabalho?

Eu acho que não tem nada para melhorar o meu trabalho. Eu sei anotar, escrevo os nomes das pessoas, o nome do curativo e do dente.

12- Você participou de algum curso?

Eu participei de um curso junto com auxiliares de saúde no PI Diauarum em 1997, de julho até agosto.

13- Como você usa o material da COLGATE?

Eu uso COLGATE quando eu atendo, eu peço para eles pegarem quando acabar. sei que é muito difícil de chegar, mas o Distrito manda direto para o Xingu.

14- Como você anota o seu trabalho e faz o relatório de atendimento?

Eu anoto depois de atender as pessoas e faço relatório de atendimento. quantas aplicações de flúor. IRM e amálgama.

15- Você quer dizer mais alguma coisa?

Eu preciso ter mais material no meu consultório para atender outras aldeias: pasta, escova, fio dental etc.

16- O que você faz com seu dinheiro?

Eu não recebo pelo meu trabalho. 
QUESTIONÁRIO PARA O AGENTE DE SAÚDE BUCAL julho/2000

Nome: Inamurap Kaiabi

Aldeia Kururu

Local de nascimento: Aldeia próxima ao Diauarum

Data de nascimento: 07/05/71

Filiação: Pakupep Kaiabi e Kunha'up Kaiabi

RG: 1248140 - Brasilia - DF

1- Quem alfabetizou você? Onde você estudou?

Eu comecei a estudar com Mariana no Diauarum, fiquei morando com Y'po.

2- Por que você resolveu ser agente de saúde bucal?

Primeiro eu fiquei agente de saúde. Então Murici bebeu álcool, ele ia ser agente de saúde bucal. Eu fiquei doente lá no Diauarum, eu tive malária. Então as lideranças me escolheram para ficar no lugar de Murici. Nessa época eu já era pajé, eu ainda estava solteiro. Agora eu parei com meu trabalho de pajé, não rezo muito o pessoal porque uma criança ficou doente, eu rezei, ela não melhorou e o pessoal achou que eu fiz mal para ela.

3- Quem ensinou esse trabalho para você?

Eu aprendi com Biral, ele é meu professor até hoje.

4- Como é o seu trabalho na comunidade? Você espera as pessoas procurarem o seu serviço ou é você quem chama o pessoal para ser atendido?

Eu marco dia e chamo o pessoal para atender. A criançada não tem mais medo, eu faço restauração com IRM e passo flúor, ensino os meninos a escovar os dentes. Agora eu estou começando a usar amálgama.

5- Você atende outras aldeias?

Eu só atendi uma vez no Sobradinho, Moiawe que arranjou gasolina para eu ir lá. Nunca mais teve gasolina.

6- Você faz algum trabalho junto ao professor da sua aldeia? Conte como é. 
Anexo 10 Estrutura do DISEIX. 


\section{ORGANIZAÇÃO DO DSX}

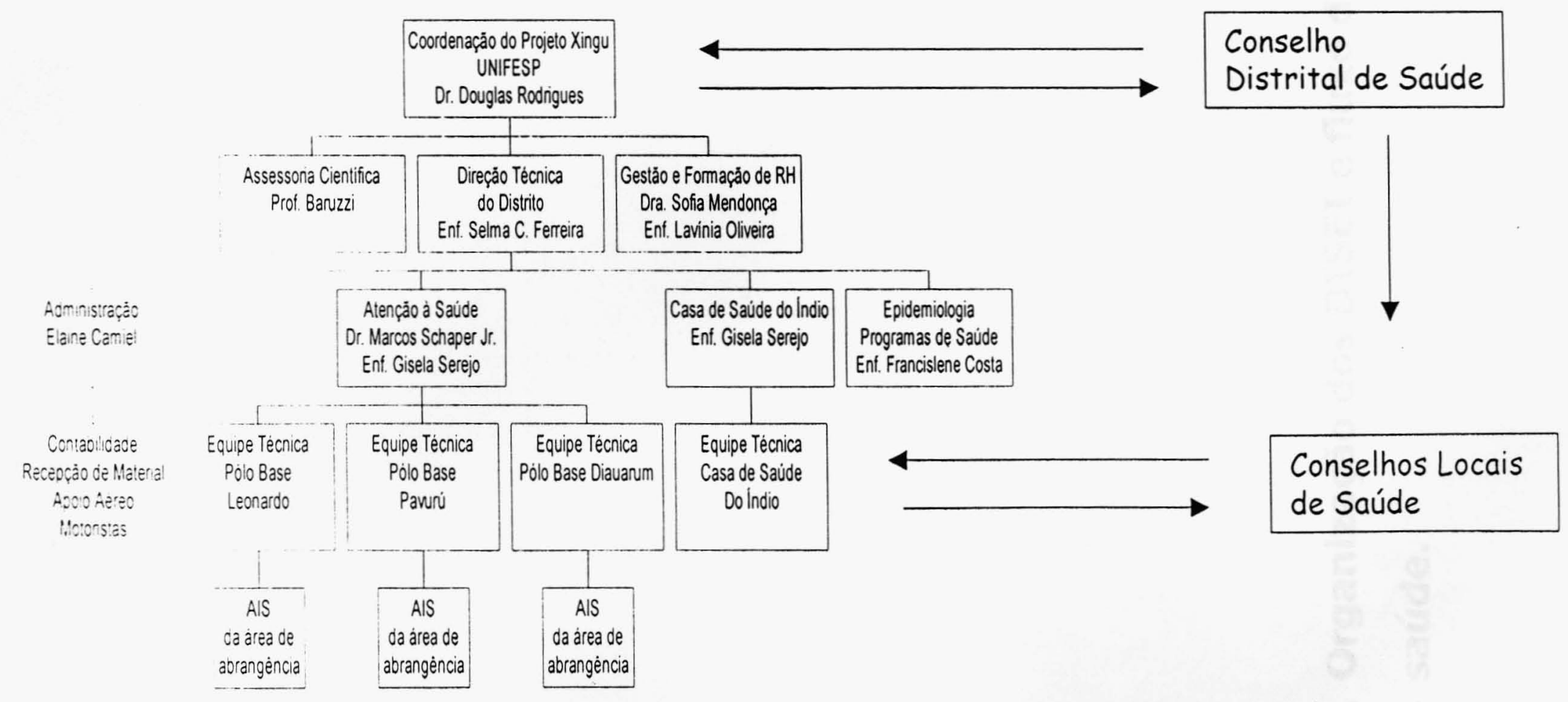


Anexo 11 Organização dos DISEI e fluxo de atenção à saúde. 


\section{DISTRITOS SANITARIOS ESPECIAIS INDIGENAS}

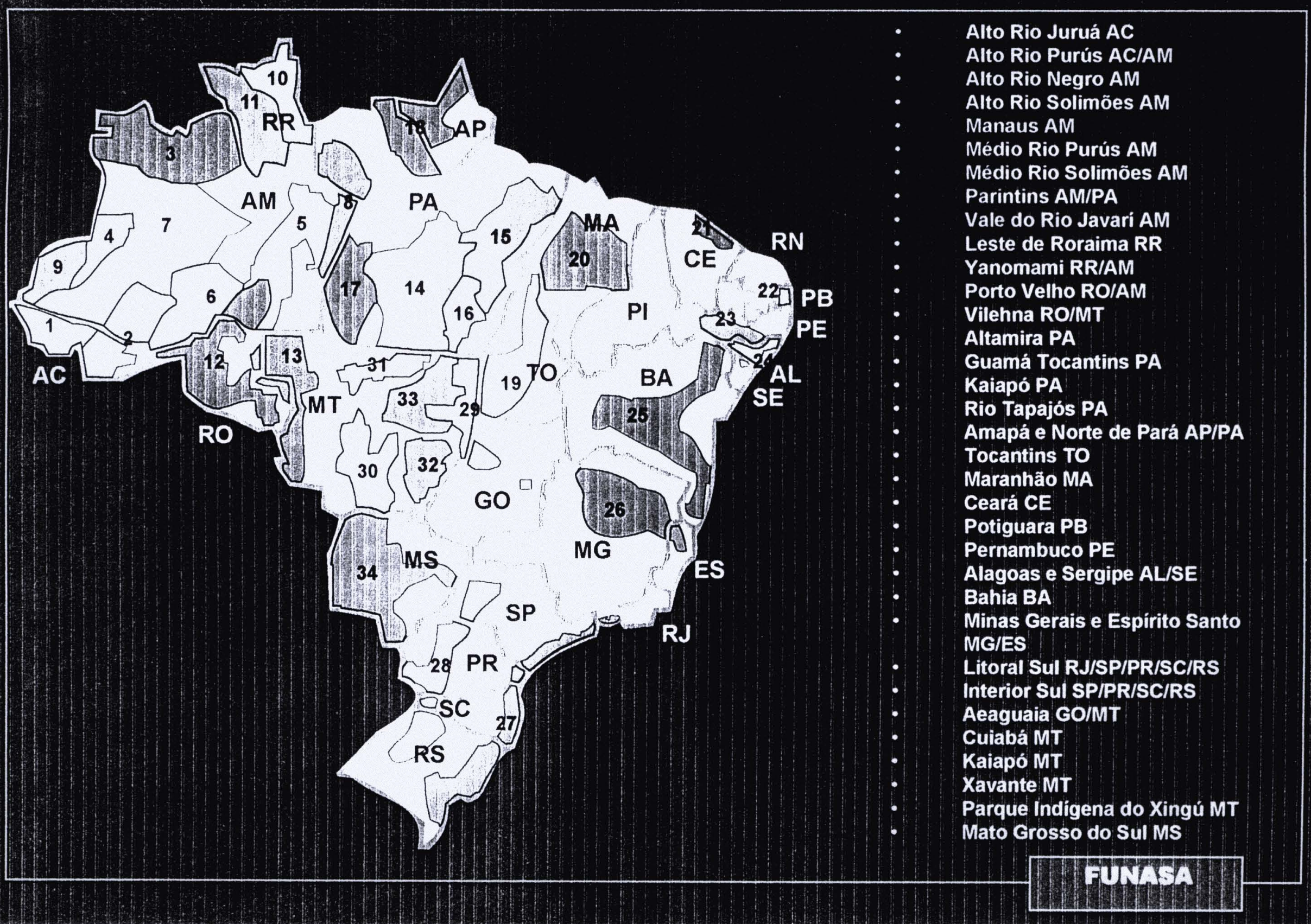




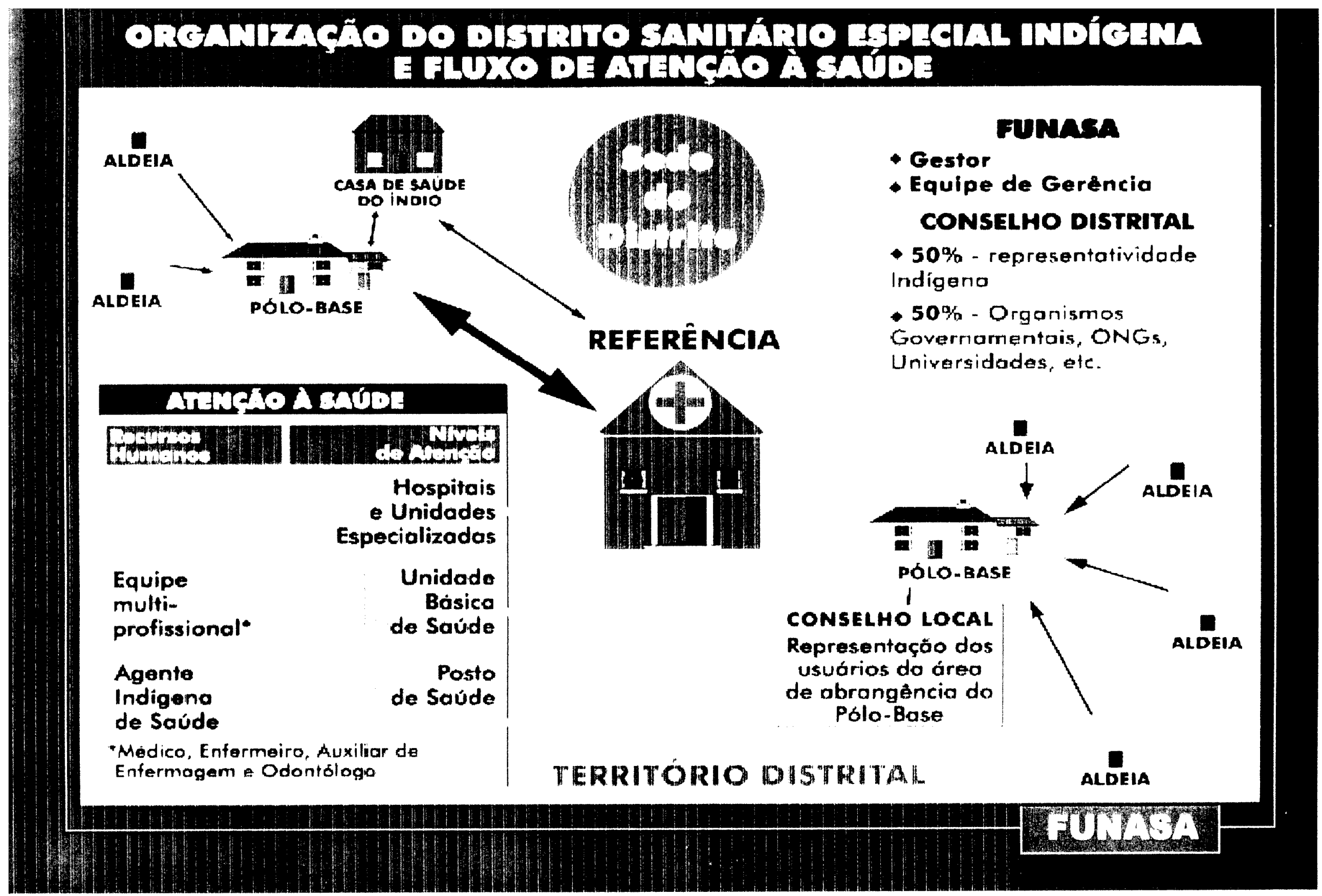


Anexo 12 Planejamento do curso e supervisão dos AIS Xingu. 


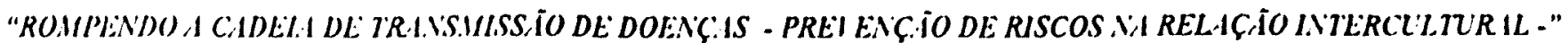

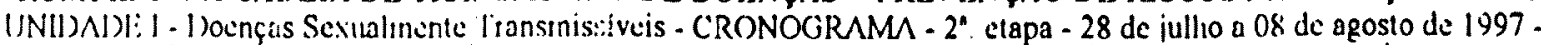

\begin{tabular}{|c|c|c|c|c|c|c|c|}
\hline horário & dia 28/07; 2'feira & dia $29 / 107$; 3efuira & dia 30/07; f'feirn & dia $31 / 07 ;$ s'feira & dia $01 / 08 ; 6^{\circ}$ feira & dia 112/118; sábado & 03/08; dumingo \\
\hline $7: 30119$ & Ull3S / rodizio & Ul3S / rodizio & UBS / rudizio & UBS / rodizio & Ulis / rodizio & UBS / rodizio & U13S / radizio \\
\hline $9:(x)$ lis & $\begin{array}{l}\text { uvaliação da visita } \\
\text { is aldcias }\end{array}$ & $\begin{array}{l}\text { avaliaçăo da visita us } \\
\text { aldeias }\end{array}$ & $\begin{array}{l}\text { pxrtuguês aplicado } \\
\text { à sailde: } \\
\text { intenuretaçióo de } \\
\text { textos do manual de } \\
\text { multiplicadores } \\
\text { DST I AIISS para as } \\
\text { áreas indígenas }\end{array}$ & $\begin{array}{l}\text { porlugués aplicado } \\
\text { a saúde: } \\
\text { interprelaçato de } \\
\text { texlos do manual de } \\
\text { multiplicadores } \\
\text { IST / AIIS } \\
\text { - redação }\end{array}$ & $\begin{array}{l}\text { português aplicado } \\
\text { d saude: } \\
\text { interpretação de } \\
\text { textos do manual de } \\
\text { multiplicadores } \\
\text { DST / ADDS } \\
\text { - redação }\end{array}$ & $\begin{array}{l}\text { matcmática } \\
\text { aplicada a saude: } \\
\text { neccssidades de } \\
\text { malcmática na } \\
\text { prática do AIS - } \\
\text { ábaco operação de } \\
\text { soma }\end{array}$ & $\begin{array}{l}\text { malemática } \\
\text { aplicada à sauide: } \\
\text { locullização } \\
\text { coordenadas } \\
\text { tabelas / abaco }\end{array}$ \\
\hline $12: 00 \mathrm{hs}$ & nlmogo & almaco & almoco & almoço & almoso & almaco & almoco \\
\hline $14: 00 \mathrm{hs}$ & $\begin{array}{l}\text { "Ivaliaça do da visila } \\
\text { is aldeias }\end{array}$ & $\begin{array}{l}\text { praduçãa de material } \\
\text { didático para o } \\
\text { trabalho nas aldeias }\end{array}$ & $\begin{array}{l}\text { produção de } \\
\text { material didático } \\
\text { para o trabalho nas } \\
\text { aldeias }\end{array}$ & $\begin{array}{l}\text { tevisđ̃o: estratégias } \\
\text { de prevençåo por } \\
\text { aldeia / xingu }\end{array}$ & $\begin{array}{l}\text { revisło: estratégias } \\
\text { por aldeia / xingu }\end{array}$ & $\begin{array}{l}\text { matemática } \\
\text { continuaçắo }\end{array}$ & $\begin{array}{l}\text { matemática } \\
\text { continuação }\end{array}$ \\
\hline $17: 00 \mathrm{hs}$ & $\begin{array}{l}\text { UBS I todizio de } \\
\text { grujos }\end{array}$ & $\begin{array}{l}\text { UBSS I rodizio de } \\
\text { grupos }\end{array}$ & $\begin{array}{l}\text { UBS I rodizio de } \\
\text { grupos }\end{array}$ & $\begin{array}{l}\text { IJBS / rodizio de } \\
\text { grupos }\end{array}$ & $\begin{array}{l}\text { UH3S / rodizio de } \\
\text { gnipos }\end{array}$ & $\begin{array}{l}\text { UBS / rodizio de } \\
\text { gupos }\end{array}$ & $\begin{array}{l}\text { U13S / rodizio de } \\
\text { grupos }\end{array}$ \\
\hline $18: 30 \mathrm{hs}$ & jantar & jantar & jantar & jantar & jantar & jentar & jantar \\
\hline \multicolumn{8}{|l|}{ nolte } \\
\hline horarlo & $\left(1+/ 118 ; 2^{\circ}\right.$ feira & $05 / 08 ; 3^{2}$ feira & $\left(60 / 08_{i} t^{\prime}\right.$ feira & 107/108; 54feira & 08/08; 6"feira & 09/08; sábado & 10/08; domingo \\
\hline $7: 30115$ & UIBS / roditio & U1BS / rodizio & UBS / rodizio & IJBS / rodizio & UIBS / rodizio & & \\
\hline $9: 100 \mathrm{hs}$ & $\begin{array}{l}\text { malemática aplicada } \\
\text { î saúdo }\end{array}$ & $\begin{array}{l}\text { matcinática aplicada a } \\
\text { saúde }\end{array}$ & $\begin{array}{l}\text { matemática } \\
\text { aplicada à saúde }\end{array}$ & $\begin{array}{l}\text { matemática } \\
\text { aplicada à saúde }\end{array}$ & avaliaçăo & fim & \\
\hline 12:(M) hs & $11 \max 0$ & almojo & nlmoço & tImoco & almoso & & \\
\hline 1f:(N) has & $\begin{array}{l}\text { Inulemílica aplicada } \\
\text { a saúde }\end{array}$ & $\begin{array}{l}\text { matemńlica aplicada d } \\
\text { sande: }\end{array}$ & $\begin{array}{l}\text { malemática } \\
\text { aplicada d̀ sanide }\end{array}$ & $\begin{array}{l}\text { matemática } \\
\text { uplicada d saude }\end{array}$ & avuliação & & \\
\hline 17:011 hs & U13S / rodizio & U/3S / rodizio & ULBS / rodizio & JIBS / rodizio & UI3S / rodizio & & \\
\hline $\begin{array}{l}\text { 18:30 hs } \\
\text { UIBS -U }\end{array}$ & $\begin{array}{l}\text { jantar } \\
\text { arle Básica de Sulude }\end{array}$ & jantar & jantar. & jantar & jantar & & \\
\hline
\end{tabular}

- UBBS - Unidarle Básica de Sando 


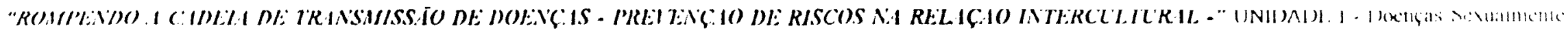

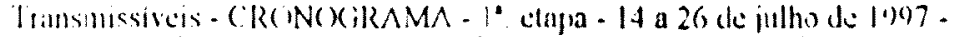

\begin{tabular}{|c|c|c|c|c|c|c|c|}
\hline horario & dia $14 / 07 ; 2^{\prime}$ feira & dia $15 / 07 ; 3^{4}$ feira & dia $16 / 07$; tefeira & dia $17 / 07 ; 5^{\prime}$ feira & dia $18 /(1) 7 ; 6^{\circ}$ fcira & dia $19 / 117$; sabado & 201177; dumingo \\
\hline $7: 30 \mathrm{hs}$ & atertua olicial & $\begin{array}{l}\text { UI3S / rodirio de } \\
\text { grupos }\end{array}$ & $\begin{array}{l}\text { Ulis / rodizio de } \\
\text { gesupos }\end{array}$ & $\begin{array}{l}\text { INBS i rodicio de } \\
\text { enupos }\end{array}$ & $\begin{array}{l}\text { Ulis / rocizio de } \\
\text { gnupos }\end{array}$ & $\begin{array}{l}\text { LBS / rodivio de } \\
\text { eupos }\end{array}$ & $\begin{array}{l}\text { U13S / } 10 \mathrm{~d} / 710 \mathrm{di} \\
\text { gnipos }\end{array}$ \\
\hline $9:(k) / 1,9$ & $\begin{array}{l}\text { divisio de grupos; } \\
\text { escilla de rollizio na } \\
\text { IJ3S }\end{array}$ & $\begin{array}{l}\text { relumanilo vigilancia } \\
\text { cpidemiologica }\end{array}$ & $\begin{array}{l}\text { conceitos gerals: } \\
\text { d(xellyas } \\
\text { sexiuilmente } \\
\text { trunsmissiveis }\end{array}$ & $\begin{array}{l}\text { manifestacodes } \\
\text { clinicas de l)STl: } \\
\text { classificaçăo } \\
\text { tratumento }\end{array}$ & $\begin{array}{l}\text { manifestaçdes } \\
\text { clinicas de I)ST: } \\
\text { classificeçăo / } \\
\text { trataniento }\end{array}$ & $\begin{array}{l}\text { Infecçào pelo llIV } \\
\text { a } A D S S \\
\text { hisiória / conccitos } \\
\text { getais }\end{array}$ & lazer-esporles \\
\hline 12:(W) hs & almogo & almo;o & almoço & almoço & almoso & almoco & almojo \\
\hline $14: 011 \mathrm{hs}$ & $\begin{array}{ll}\text { identificação } & \text { de } \\
\text { problcınas } & \text { na } \\
\text { iclaçdo intercultural }\end{array}$ & $\begin{array}{l}\text { retomanilo } \\
\text { vigilencia } \\
\text { cpidemiológica }\end{array}$ & $\begin{array}{l}\text { modo } \\
\text { Iransmissão } \\
\text { DST }\end{array}$ & $\begin{array}{l}\text { manifestaçöes } \\
\text { clinicas de DST: } \\
\text { classificação } \\
\text { tratamento }\end{array}$ & $\begin{array}{l}\text { manilestaçóes } \\
\text { clinicas de I)SI: } \\
\text { classificação / } \\
\text { trataniento }\end{array}$ & $\begin{array}{l}\text { Como se transmite } \\
\text { olllV - AIISS? }\end{array}$ & \\
\hline $17: 00 \mathrm{hs}$ & $\begin{array}{l}\text { U13S / rodizio de } \\
\text { grupos }\end{array}$ & $\begin{array}{l}\text { Ul3S I rodirio de } \\
\text { grupos }\end{array}$ & $\begin{array}{l}\text { UBS I rodiz:so de } \\
\text { grupus }\end{array}$ & $\begin{array}{l}\text { UBS I rodizio de } \\
\text { grupos }\end{array}$ & $\begin{array}{l}\text { Ul3S I rodizio de } \\
\text { gnipos }\end{array}$ & $\begin{array}{l}\text { LBBS / rodizio de } \\
\text { grupos }\end{array}$ & $\begin{array}{l}\text { UJ3S / lodizio de } \\
\text { grupos }\end{array}$ \\
\hline 18:30 hs & jantar & jantar & jantar & jantar & jantar & jentar & jantar \\
\hline \multicolumn{8}{|l|}{ noitc } \\
\hline horário & $21 / 117 ; 2^{\prime}$ feira & 22/07; 3'feira & $23 / 07$; f'feira & $24 / 07 ; 5^{2}$ feira & 25/07; 6'feira & $26 / 07$; sábado & $27 / 07 ;$ domingo \\
\hline $7: 30 \mathrm{lis}$ & IJIBS/radizio & UI3S / rodizio & UBS / rudizio & IJBS / rodizio & Ul3S : radizio & UBS / rodizio & visita i aldeia \\
\hline $9:(x)$ lis & $\begin{array}{l}\text { Estadiamento da } \\
\text { AlISS }\end{array}$ & $\begin{array}{l}\text { prevenindo o risco } \\
\text { scxualidadc: } \\
\text { uso de preservativo, } \\
\text { diagnostico } \\
\text { acompanhamento } \\
\text { precoces; busca ativa } \\
\text { de comunicantes. }\end{array}$ & $\begin{array}{l}\text { ptevenindo o risco } \\
\text { lécnicas de } \\
\text { cnfermagen - } \\
\text { bioscgurança: } \\
\text { limpuza. } \\
\text { desinfecção, } \\
\text { csterilização. } \\
\end{array}$ & $\begin{array}{ll}\text { estratégias } & \text { de } \\
\text { prevençâa } & \text { por } \\
\text { aldeia / xingu } & \end{array}$ & $\begin{array}{lr}\text { aptesentaçăo } & \text { de } \\
\text { estratégias } & \text { por } \\
\text { aldeia/xingu } & \end{array}$ & $\begin{array}{l}\text { avaliação oral e } \\
\text { escrita }\end{array}$ & continuaç3o visita \\
\hline $12: 00 \mathrm{hs}$ & almoco & alma;o & almoço & almaço & almogo & almoco & almoco \\
\hline $14:(x)$ hs & $\begin{array}{l}\text { estadiamento da } \\
\text { AlISS }\end{array}$ & $\begin{array}{l}\text { prevenindo o risco } \\
\text { sexualidadc: } \\
\text { uso de preservativo; } \\
\text { diagnóstico } \\
\text { acompanhanento } \\
\text { precoces: husca ativa } \\
\text { de comunicanles. }\end{array}$ & $\begin{array}{l}\text { prevenindo o risco } \\
\text { lécnicas } \\
\text { enfermagem - } \\
\text { bioscgurança: } \\
\text { lisnpuza. } \\
\text { desinfeç̧ăo, } \\
\text { esterilização. } \\
\end{array}$ & $\begin{array}{ll}\text { estratcogias } & \text { de } \\
\text { prevençð̃o } & \text { por } \\
\text { aldeia / xingu } & \end{array}$ & $\begin{array}{lr}\text { apresentuçåo } & \text { de } \\
\text { estratégias } & \text { por } \\
\text { aldeia / xingu } & \end{array}$ & $\begin{array}{l}\text { avaliaçāo oral e } \\
\text { escrita }\end{array}$ & continulaçảo visita \\
\hline 17:00 hs & IJ3s.s / rodizio & UIBS/ rodizio & UIBS / rodizio & IBSS / rodizio & Ul3S / rodizio & UBS / rodizio & UIBS / rodizio \\
\hline $18: 311 \mathrm{hs}$ & ianlat & juntar & jantar & juntar & jantar & jantar & jantas \\
\hline
\end{tabular}

- Inss - Unidade Básica de Sande 
LOCALIDADES ATENDIDAS

- PIV Kuluene

- Tanguro

- Afukuri

- Pl Leonardo

- Iwalapiti

- Matipu

- Kuikuro

- Kalapalo

- Nafuka

- Waurá

- Stenia

- Morená

- Boa Esperança

- Terra Preta

- Ikpeng

- Pavuru

- Guarujá

- Tuiararé

- Barranco Alto

- Itai

- Diauarum

- Capivara

- Ngôsoko

- Rico

- Cururu

- Tubatuba

- Maraca

- Sobradinho

OBSERVAÇÕES DAS ALDEIAS VISITADAS:

Fomos sempre bem recebidas pelas lideranças das aldeias e os AIS ( onde havia ), demonstravam estar muito satisfeitos com o nosso trabalho de assistência integral.

Fizemos muitos atendimentos médicos e procedimentos de enfermagem dentro desse Programa de Imunização.

Pontos comuns observados:

- Muito mato em torno.

- Muitos mosquitos

- Muitos cães

- Falta de assistência básica 
- Falta de orientação em Saneamento Básico

Fossa:

- Matipu

- P.I. Leonardo

- P.I. Pavuru

- P.I. Diauarum

- Capivara

- Cururu

Lixo:

- Obs: nos Postos Indigenas Leonardo, Pavuru e Diauarum tem buraco do lixo e os mesmos são queimados

- Nas aldeias onde tem um AIS os mesmos me informaram que queimam o lixo após os atendimentos

- Vê-se muito lixo não orgânico espalhados nas aldeias ( Garrafa plástica, saco de biscoito, latas vazias e eníerrujadas, etc.)

UBS:

- Tanguro

- Kuikuro

- Nafuka

- Morená

- Guarujá

- Tuiararé

- Rico

- Cururu

- Tubatuba

- Capivara

Obs.: os atendimentos nas outras aldeias são feitos normalmente na casa do AIS; onde também estocam as medicações em caixas de papelão e em lugares ao alcance de crianças

FILTRO DE ÁGUA:

- Tuiararé

- Capivara

- Ricô

\section{AIS SUPERVISIONADOS:}

- Tanguro - Cláudio

- Afukuri - Rakamu

- Iawalapiti - Anuiá 
- Matipu - Kulika/Urisé

- Nafuká- Tafuraki

- Kuikuro - Talico/ Ioy

- Waurá - Yanahim

- Kalapalo - Aru

- Pavuru Marite/PiwaráArawe

- Tuiararé Moiawé Aramut/Yawe/Tumain

- Diauarum - Poikô

- Ngôsoko-Benti

- Ricô-Koiroro

- Cururu-Preyawp

- Tubatuba - Tamaricô/Doriu

- Parque Samba - Pichanhã

- Maraca-Puran

- Sobradinho-Djuajup

- Capivara - Yawot Yefuka

Gostaria de Ter estado com mais tempo para com os alunos em formação, pois senti que muitos tem dúvidas básicas, de técnicas de enfermagem, horários de medicações, tratamentos, palavras técnicas que oras os confunde. Todos esses nomes acima fizeram cursos de Agentes de Saúde ou estão fazendo o curso de Auxiliares de Enfermagem Indígena e em minhas observações raros foram aqueles que levaram a sério os ensinamentos de Saneamento Básico.

Estava preocupada com a ausência dos alunos em formação, até que no dia 20/03 estava no Kuikuro, pedimos avião para a remoção de um paciente grave e para minha surpresa quando esse pousa um dos alunos ( Yefuka) aproveitou a carona e veio acompanhar o término da vacinação e seguir para o P.I. Leonardo para participar da reunião com o presidente da FUNAI. Ao chegarmos no Posto para meu espanto estavam presente : Aiguré, Tafurak, Yanahin, Yefuká que nos encontrou no Kuikuro e Moiawô que já estava nos acompanhando desde o início da vacinação. Fiquei muito preocupada pois como iria fazer para leva-los comigo nessa atividade, não tinha barco suficiente para cumprir essa jomada e ao mesmo tempo não poderia perder essa oportunidade; não tinha nem como;

Estávamos ainda com três alunas de Enfermagem, mesmo que dividíssemos a equipe não caberia todos nos barcos, mas, sem problemas,

A melhor forma ainda é conversar, e foi o que aconteceu; expliquei o problema e a melhor forma encontrada foi que todos iriam participar da vacinação em suas aldeias e que numa próxima eu estaria me programando melhor e articulando a viabilização de todos os alunos participarem. Todos estavam ali não só com esse propósito e sim de ter com o presidente da FUNAI e ver a nova UBS do P.I. Leonardo.

Moiawê, Carla ,Claudia e Vidineza seguiram na lancha para o P.I.Diauarum, Yefuka, Aiguré seguiram de barco com as Lideranças das áreas de abrangência do Pavuru e do Diauarum .

Muitos Agentes de Saúde que fizeram pela primeira vez o curso, já estão fazendo IM, administrando medicações que nem mesmo sabem para que serve. Algumas aldeias recebem medicamentos do municipio e o mesmo por falta de 


\section{Anexo 13}

\section{Relação de Leis, Decretos e Pareceres consultados.}

Brasil. Constituição Federal de 1988. Gráfica do Senado. Brasilia, 1988.

Brasil. Decreto lei no 1141, de maio de 1994. Rege o Decreto no 23 que disciplina condições para prestação de assistência à saúde das populações indígenas. Diário Oficial da República Federativa do Brasil, Brasília, agosto 1999.

Brasil. Decreto lei no 2208, de 17 de abril de 1997. Dispõe sobre a educação profissional de nível técnico. Diário Oficial da República Federativa do Brasil, Brasília, 1997.

Brasil. Decreto lei no 23, de fevereiro de 1991. Disciplina condições para prestação de assistência à saúde das populações indígenas. Diário Oficial da República Federativa do Brasil, Brasília, fevereiro 1991.

Brasil. Decreto lei no 3156, de 27 de agosto de 1999. Dispõe sobre as condições de prestação de assistência à saúde das populações indígenas no âmbito do SUS. Diário Oficial da República Federativa do Brasil, Brasília, agosto 1999.

Brasil. Lei no 9649, de 27 de maio de 1998. Dispõe sobre a organização da Presidência da República e dos Ministérios e dá outras providências. Diário Oficial da República Federativa do Brasil, Brasília, 1998.

Brasil. Medida Provisória no 1911-9 de 27 de agosto de 1999. Altera os dispositivos da Lei no 9649 de 27 de maio de 1998 que dispõe sobre a organização da Presidência da República e dos Ministérios e dá outras providências. Diário Oficial da República Federativa do Brasil, Brasília, 28 agosto 1999. 
Brasil. Medida Provisória no 1011-10 de 24 de setembro de 1999. Altera os dispositivos da Lei no 9649 de 27 de maio de 1998 que dispõe sobre a organização da Presidência da República e dos Ministérios e dá outras providências. Diário Oficial da República Federativa do Brasil, Brasília, 1999.

Brasil. Medida Provisória no 1911-8 de 29 de julho de 1999. Altera os dispositivos da Lei no 9649 de 27 de maio de 1998 que dispõe sobre a organização da Presidência da República e dos Ministérios e dá outras providências. Diário Oficial da República Federativa do Brasil, Brasília, 1999.

Brasil. Projeto de Lei no 2057/96. Dispõe sobre o estatuto das sociedades indígenas, Brasilia, 1996.

Brasil. Projeto de Lei no 4681 /96. Dispõe do funcionamento dos serviços de saúde para populações indígenas, Brasília, 1996.

Brasil. Lei no. 9.394/96 de Diretrizes e Bases da Educação, Brasília, 1996.

Ministério da Educação. Educação escolar Indígena. Referênciais Curiculares. Brasilia; 1999a.

Ministério da Educação. Parecer CNE 4/99. Educação Profissional. Brasília; 1999b.

Ministério da Educação Diretrizes Curriculares Nacionais para o Ensino de Nivel Técnico. SEMTEC. Brasília; 2000.

Ministério da Educação. Educação Profissional: referenciais curriculares nacionais para Educação Profissional de nível técnico. SEMTEC. Brasília, 2000a. 
Anexo 14 Listagem de desempenho e auto avaliação do AIS. 
CURSO DE FORMAÇAO DE AUXILIARES DE ENFERMAGEM INDIGENAS

MÓDULO III

PROJETO XAMÃ DISTRITO XINGU

FICHA DE AVALIAÇÃO DE DESEMPENHO

ACOMPANHAMENTO DE PACIENTES

Nome do aluno:

Etnia: Aldeia

\begin{tabular}{|c|c|c|c|c|c|c|}
\hline ATIVIDADE & DESEMPENHO & data & data & data & data & Assinatura do \\
\hline $\begin{array}{l}\text { Acompanhamento de } \\
\text { pacientes nos serviços } \\
\text { de saúde }\end{array}$ & $\begin{array}{l}\text { Orienta o paciente e familiares sobre os procedimentos } \\
\text { que seráo realizados } \\
\text { Realiza o preparo de exames quando necessário } \\
\text { Reune exames anteriores e encaminhamentos } \\
\text { Acompanha o paciente, apresentando-o ao serviço de saúde, } \\
\text { profissionais responsáveis e passa o caso, quando necessário } \\
\text { Atende as recomendaçס̋es e prescriçठ̋es feitas } \\
\text { Faz as anotaçठ̋es necessárias }\end{array}$ & & & & & \\
\hline
\end{tabular}

DATA

Assinatura/aluno

Assinatura/Instrutor/Supervisor

Assinatura/Coordenador/DSEI 
DISTRITO SANITÁRIO XINGU

CURSO DE FORMAÇÃO DE AUXILIARES DE ENFERMAGEM INDÍGENAS

AREA I- CONHECENDO A FAMÍLIA INDÍGENA

AREA II- ROMPENDO A CADEIA DE TRANSMISSÃO DAS DOENÇAS

AREA IV- ORGANIZANDO O PROCESSO DE TRABALHO

\section{LISTAGEM DE DESEMPENHOS}

ALUNO TALIKO KUIKUKO ÁREA DE ABRANGÊNCIA L FONARDO ENFERMEIROS E OUTROS SUPERVISORES DO SEU TRABALHO GERSON S, ANTANA DIAS

\begin{tabular}{|c|c|c|c|}
\hline DESEMPENHO & SABE & SABE POUCO & NÁO SABE \\
\hline 1. Trabalho educativo junto à comunidade & $x$ & & \\
\hline 2. Atendimento domiciliar & $x$ & & \\
\hline 3. Investigação epidemiológica-malária/Tb/DST & $x$ & & \\
\hline 4. Ordem e limpeza na unidade de saúde & $x$ & & \\
\hline 5. Recepção e atendimento na UBS & $x$ & & \\
\hline 6. História do doente e exame fisico & $x$ & & \\
\hline 7. Termometria & $x$ & & \\
\hline 8. Verificação da respiraçăo & & $x$ & \\
\hline 9. Verificação do pulso & $x$ & & \\
\hline 10. Verificação da pressão arterial & $x$ & & \\
\hline 11. Verificação do peso & $x$ & & \\
\hline 12. Verificação do peso em crianças pequenas & $x$ & & \\
\hline 13. Técnicas de biosegurança & $x$ & & \\
\hline 14. Lavagem e preparo de materiais & X & & \\
\hline 15. Técnicas de desinfecção & $x$ & & \\
\hline 16. Técnicas de esterelização & $x$ & & \\
\hline 17. Manuseio de material estéril & $x$ & & \\
\hline
\end{tabular}


18. Calçar e descalçar luvas

19. Cuidados no preparo de medicaç5o

20. Administração de medicação via oral

21. Cuidados no preparo de injeçōes

22. Administração de medicamentos por via IM

23. Administraçăo de medicamentos por via EV

24. Administraçao de hidrataçao venosa periférica

25. Administraçăo de terapia de hidratação oral

26. Inalaçăo e nebulizaço

27. Culdados a pacientes com febre

28. Medidas gerais de controle de tratamento

29. Sondagem nasogástrica

30. Identificação de DSTs

31. Administração de tratamentos padronizados

32. Açóes de controle de endemias/ malária

33. Encaminhamentos de pacientes para referências

34. Controle de estoque de medicamentos e insumos

35. Confecçåo de Relatório mensal

37. Curativo simples

38. Conservação de vacinas à nivel local

39. Acompanhamento de crianças

40. Acompanhamento de gestantes

41. Controle da situação vacinal

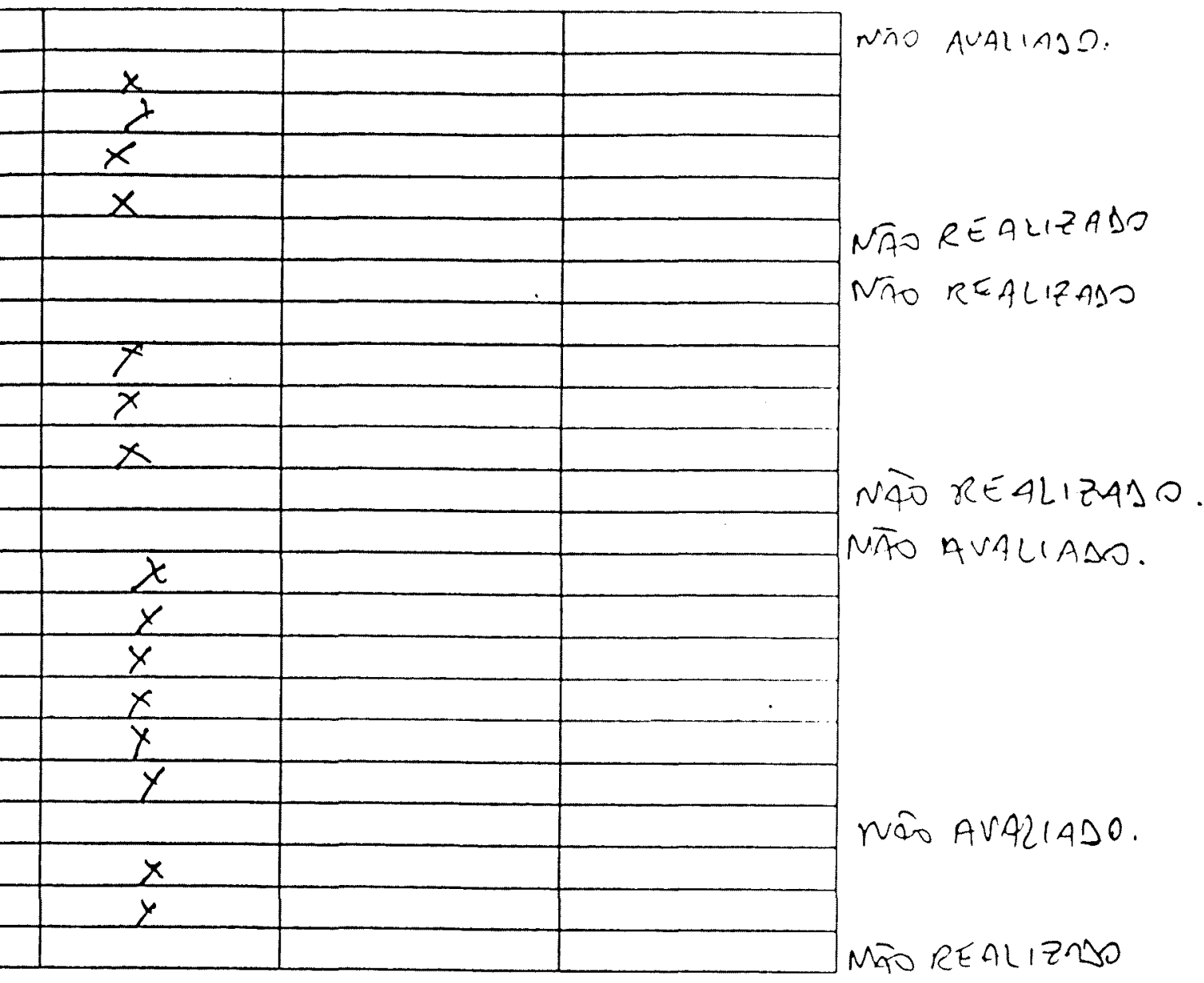


Nome:Faipuce Kayahn

Data:to..../.1.2../2.0.0.8

AUTO - AVALIAÇÃO

- Como você avalia o seu aprendizado em matemática durante todo esse periodo de formação e comente a aplicaçāo da matemática na sua área de trabalho.

Meut afrendizado com . rulaçás a

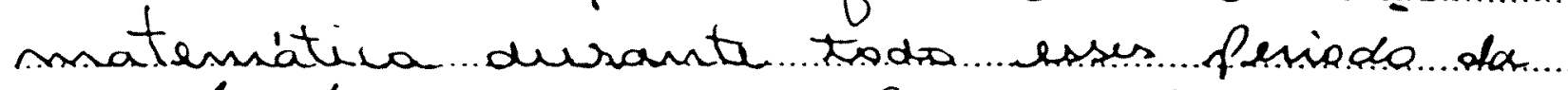
minha fonmacá en a Prendi pouso de mate mática antes en naí sabia ofue ena matensatica depois of w en a frendi matenatico fico mais facil de eu medir a dase de suledicaments

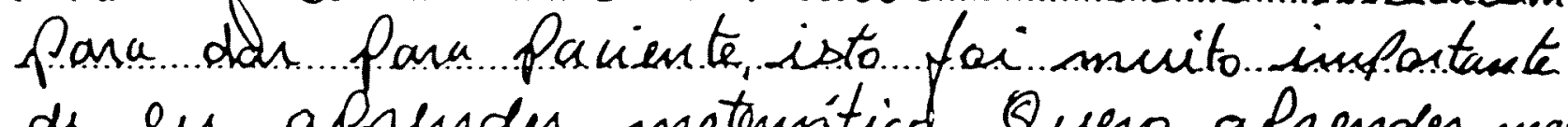

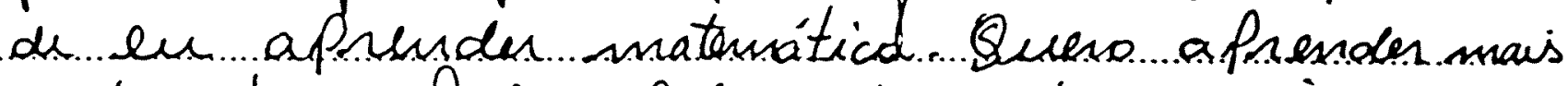

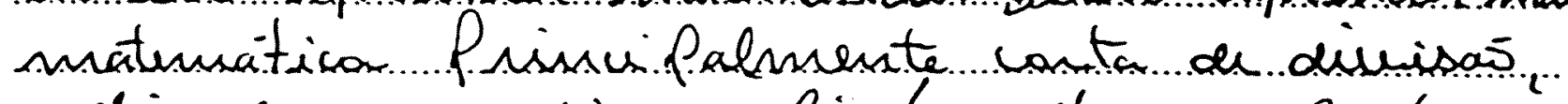

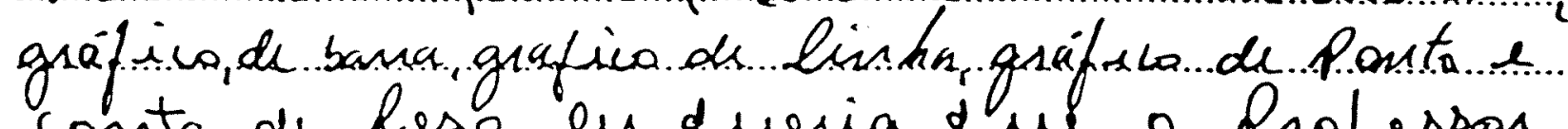

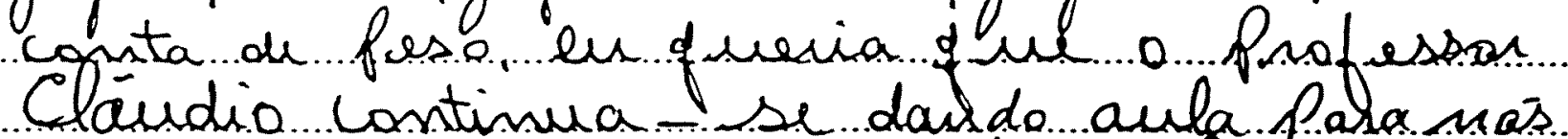

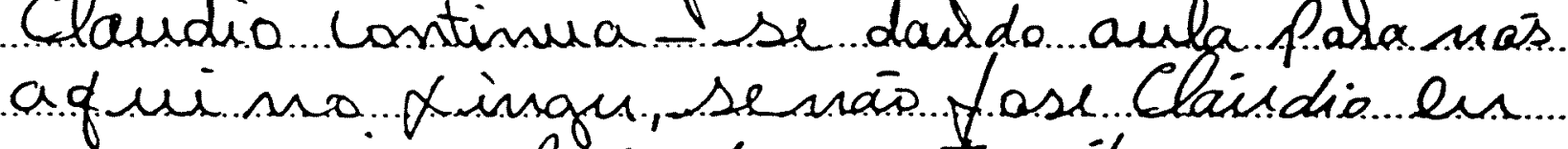
- munca ia aphender matemätica agonn...o... ofue an afrendi de malenutica da pana...

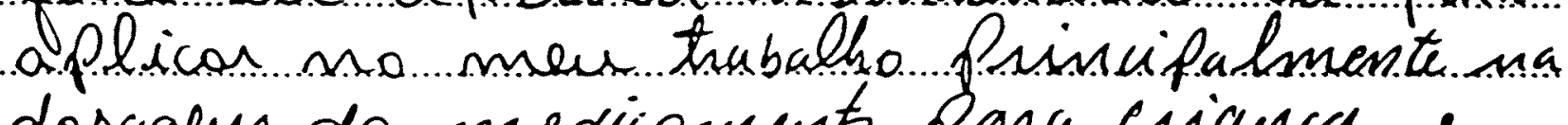
dosagen do medicosments pena criguca ne Tumbsu afrumdi os hanos dos medicomont de en hara en hou Tambem a Prende a conPantia cress comento ola crianca

- Que nota de 0 à 10 vocè daria no geral para o seu aprendizado, dedicação, etc., em matemática.

Ev elaria nota dez fana min en

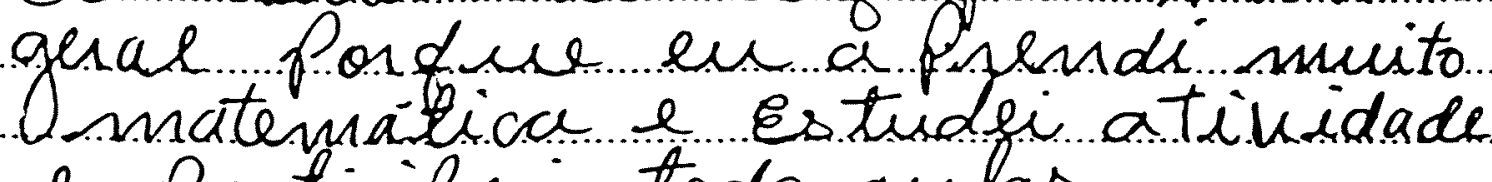
s panticipes todo aulas 
DISTRITO SANITÁRIO ESPECIAL INDÍGENA DO XINGU

Universidade Federal de São Paulo

Curso de Formação de Auxiliares de Enfermagem Indígenas

Periodo de Dispersão

Área I e III

Jun/julho de 2000

Nome Surar Kayahì

1. Escreva o que você aprendeu neste período de acompanhamento En aprender Período de acompantarueito. birei minkl dumia sutre medida de autuma itirina, Lanbin auscutar Pulnuto do lacients a contargens de pregueinaio $(M R)$ resbinatorion

2. Quais foram as suas dificuldades nestes dias?

A minha difuiculdade for na hana de prosucher a Queiza i canduta no biro futo dificuldade senpor assin de Quelmober qualquer document.

3. O que você quer aprender na próxima supervisão?

na fróxima sulenvisõo en quero aprenden mail. wodida de autibioticoi

como: nnwoxis sabbutanol en estan Jalando sobres a dosagen do todos antibiotlico

4. Faça outras sugestões ou comentários.

Quero gu conteruen viagen assin. con todea a eguipe mectica, enfemeirce; aluno baras anxiliar de unfiendger. assin as comminialade Passa confiar. noseol traballo, vamo thabalkar junte 
Anexo 15- Cronologia de viagens ao Xingu

\begin{tabular}{|c|c|}
\hline Data & Motivo \\
\hline Dezembro, 1997 & $\begin{array}{l}\text { Conhecer a área e os cursos de } \\
\text { AIs }\end{array}$ \\
\hline Agosto, 1998 & Supervisão prática de AIS e AEI \\
\hline Maio, 1999 & Vacinação e supervisão AIS \\
\hline Agosto, 1999 & $\begin{array}{l}\text { Avaliação individual dos AIS e dos } \\
\text { cursos com a ETS/MT }\end{array}$ \\
\hline Setembro, 1999 & $\begin{array}{l}\text { Treinamento de novos } \\
\text { profissionais e supervisão de AEI }\end{array}$ \\
\hline Dezembro, 1999 & $\begin{array}{l}\text { Curso AEI } \text { e vigilância } \\
\text { epidemiológica para malária }\end{array}$ \\
\hline Fev/março, 2000 & Curso AEI e supervisão AIS \\
\hline Junho, 2000 & Supervisão AEI e AIS \\
\hline Setembro, 2000 & Curso AEI \\
\hline Dezembro, 2000 & Curso AIS e supervisão AEI \\
\hline Janeiro, 2001 & $\begin{array}{l}\text { Treinamento de novos } \\
\text { profissionais e supervisão AEI }\end{array}$ \\
\hline Setembro, 2001 & Supervisão AIS e AEI \\
\hline Novembro, 2001 & $\begin{array}{l}\text { Treinamento de profissionais e } \\
\text { supervisão AIS e AEI }\end{array}$ \\
\hline
\end{tabular}


Anexo 16- Formação de Agentes indígenas de saúde. Avaliação de Produtos elaborada pela FUNASA, 2001. 
FICHA DE AVALIAÇÃO FINAL

\begin{tabular}{|c|c|c|c|c|}
\hline Atividade & Desempenhos & SIM & NÁO & INST \\
\hline $\begin{array}{l}\text {-Cadastro das } \\
\text { familias } \\
\text {-Recepção e } \\
\text { Atendimento } \\
\text {-Acompanhamento e } \\
\text { controle de diarréia } \\
\text {-Acompanhamento e } \\
\text { Controle de IRA } \\
\text {-Termometria } \\
\text {-Administração de } \\
\text { Hidratação Oral } \\
\text {-Verificação da } \\
\text { Respiração } \\
\text {-Organização do } \\
\text { Espaço de Trabalho } \\
\text {-Atendimento } \\
\text { Domiciliar } \\
\text {-Visita domiciliar }\end{array}$ & 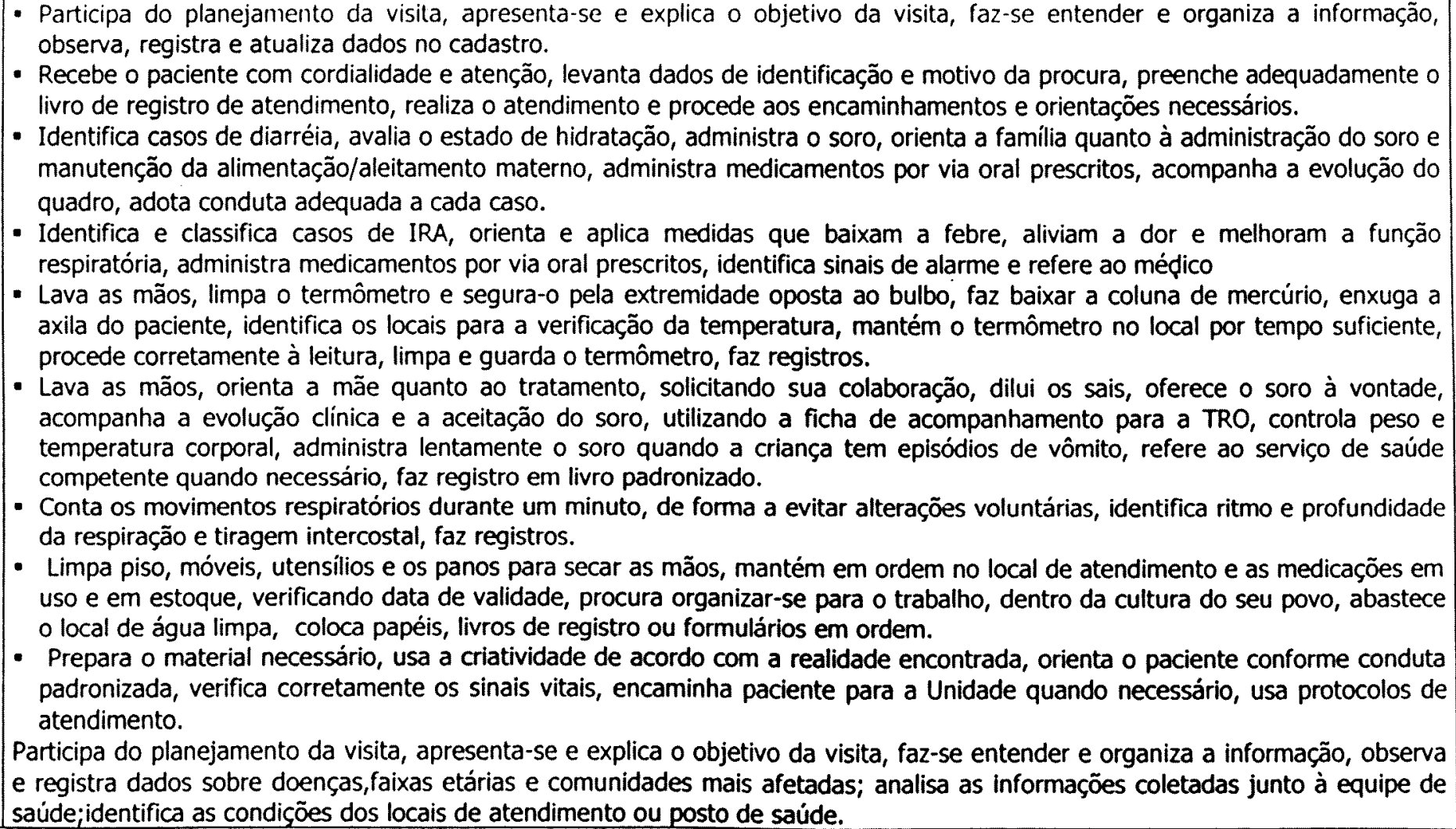 & . & & \\
\hline
\end{tabular}

\begin{tabular}{|c|c|c|}
\hline Data: & Aluno: & Enfermeiro Instrutor/Supervisor: \\
\hline \multicolumn{2}{|c|}{ Coordenador/Supervisor da instituição de ensino: } & Coordenador/DSEI: \\
\hline
\end{tabular}


¿UMSO UE ROKMAĻAO UE AGENTES INDIGENAS DE SAÚDE / MÓDULO INTRODUTÓRIO

FICHA DE REGISTRO DE FATOS

\section{N̄ŌM̄E DOO ĀLUŪNO:}

$\overline{E T N I} \overline{\mathrm{A}}$ :

ALDEEIA:

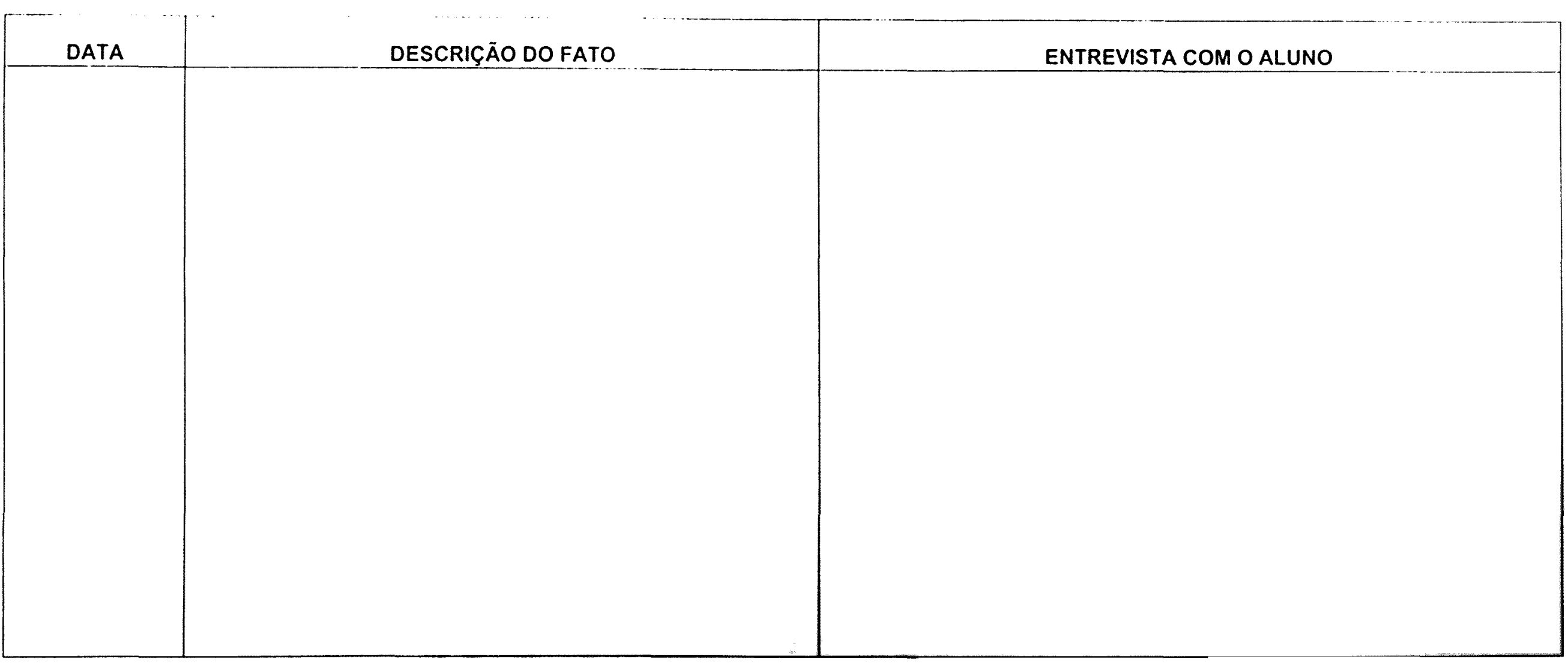


6 -Atividades pedagógicas para a dispersão - conteúdo programático

1- O posto de saúde

- O que existe no posto de saúde: medicamentos, instrumentos, aparelhos etc.

- O yue se faz no posto de saúde: atender doentes, armazenar medicamentos, fazer tratamentos (administração de medicamentos padronizados, curativos etc)

- Porque é importante cuidar do posto de saúde: limpeza, organização etc.

2- O termômetro

- Utilização: para que serve, como se usa.

- Classificação da temperatura: sem febre, com febre alta/baixa

3- O estetoscópio

- Utilização do estetoscópio: para que serve, como se usa

- Identificação de ruído na ausculta pulmonar

t- Prática da abordagem de pacientes com diarréia e IRA

- Identificação do doente

- História da doença

- Exame do doente

- Conduta

\section{5- Registro de saúde}

- Cadastro das famílias

- Livro de atendimentos diários

- Óbitos

- Nascimentos

- Encaminhamentos de pacientes

- Acompanhamento de gestantes.

\section{2 - Equipe Técnica}

- Ena de Araújo Galvão-RH/VIGISUS/Coordenadora dos Trabalhos

- Estela Wurker - ISA/SP

- Herbert Pereira de Melo - CRH/FNS

- Lavinia Santos de Souza Oliveira-EPM/SP

- Maria Aparecida A. Guerra-COSAI/FNS

- Maria Bittencourt - APINA/AP

- Marina Machado - SSL/AM

- Suzana Grillo-FUNAI. 
COORDENAÇĀO GERAL DE PLANEJAMENTO E AVALIAÇĀO DE SAỦDE

COORDENAÇĀO DE APOIO À GESTÄO E PARTICIPAÇÄO SOCIAL

FORMAÇĀO DE AGENTES INDIGENAS DE SAU்DE - AVALIAÇĀO DE PRODUTOS

\begin{tabular}{|l|l|l|}
\hline DSEI: & Número de AlS existentes: e capacitados: & Número de comunidades: \\
\hline
\end{tabular}

\section{MÓDULO INTRODUTÓRIO}

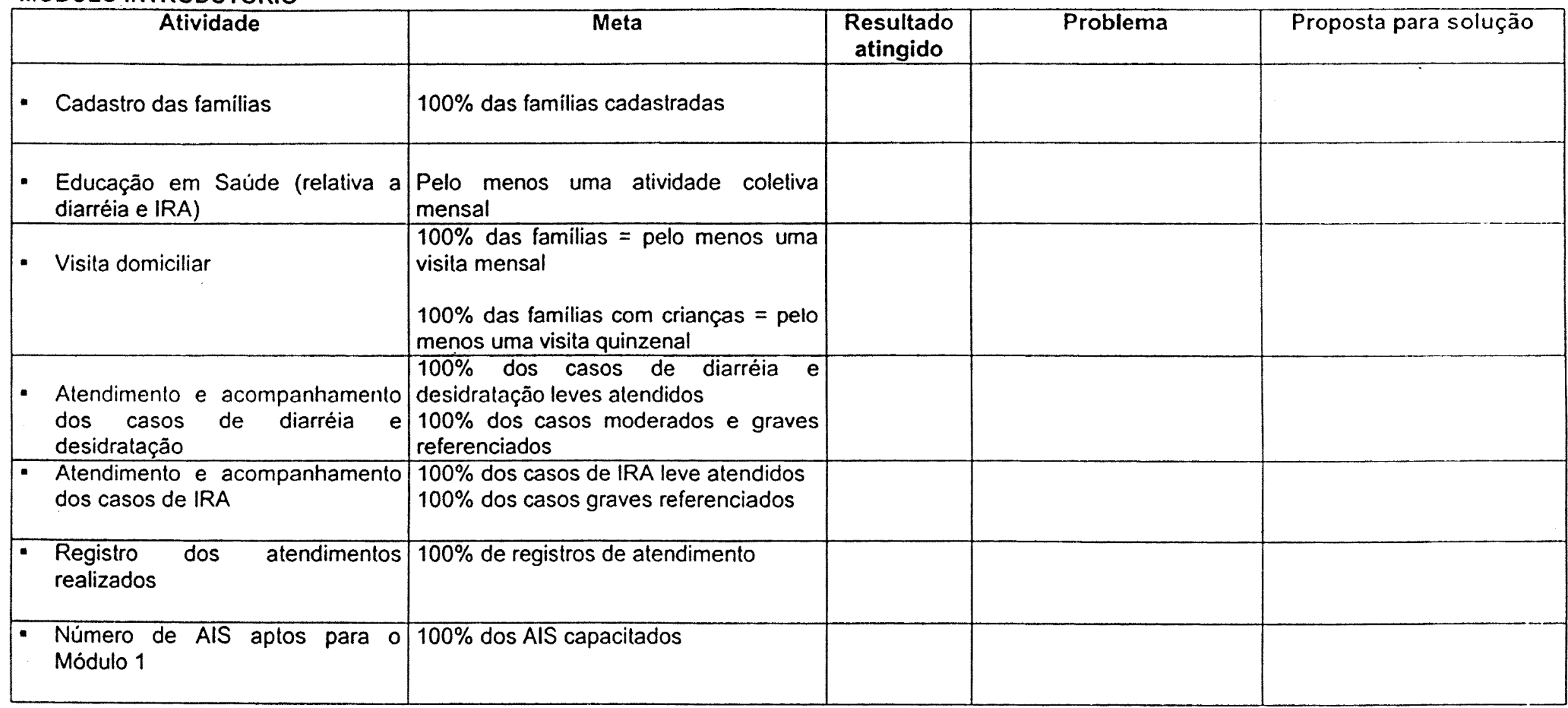




\section{FORMAÇÃO DE AGENTES INDIGENAS DE SAÚDE - AVALIAÇĀO DE PRODUTOS}

\begin{tabular}{|c|c|c|c|}
\hline DSEI: & Número de AIS existentes: & e capacitad & Número de comunidades: \\
\hline
\end{tabular}

\section{MÓDULO 1}

\begin{tabular}{|c|c|c|c|c|}
\hline Atividade & Meta & $\begin{array}{l}\text { Resultado } \\
\text { atingido }\end{array}$ & Problema & Proposta de solução \\
\hline Alualização do cadastro das familias & $\begin{array}{l}\text { Manutenção de } 100 \% \text { do } \\
\text { alualizado }\end{array}$ & & & \\
\hline $\begin{array}{l}\text { Educação em Saúde (relativa a tuberculose, } \\
\text { malária e alimentação/desnutirção)) }\end{array}$ & $\begin{array}{l}\text { Pelo menos uma atividade coletiva } \\
\text { mensal }\end{array}$ & & & \\
\hline Visita domiciliar & $\begin{array}{l}100 \% \text { das familias = pelo menos uma } \\
\text { visita mensal } \\
100 \% \text { das familias com crianças = pelo } \\
\text { menos uma visita quinzenal }\end{array}$ & & & \\
\hline $\begin{array}{l}\text { Busca ativa de casos e dos comunicantes de } \\
\text { tuberculose }\end{array}$ & $\begin{array}{l}\text { Cobertura de } 100 \% \text { da população com } \\
\text { identificação e referência de } 100 \% \text { dos } \\
\text { casos de sintomáticos respiratórios e } \\
\text { dos comunicantes }\end{array}$ & & & \\
\hline Agendamento de vacina $B C G$ & Cobertura de $100 \%$ dos recém nascidos & & & \\
\hline $\begin{array}{l}\text { Acompanhamento do tratamento padronizado } \\
\text { de tuberculose }\end{array}$ & Acompanhamento de $100 \%$ dos casos & & & \\
\hline $\begin{array}{l}\text { Identificação e encaminhamento dos casos } \\
\text { suspeitos de malária clássica }\end{array}$ & $\begin{array}{l}\text { Identificaçāo e referência de } 100 \% \text { dos } \\
\text { casos em um periodo de } 24 \text { horas }\end{array}$ & & & \\
\hline $\begin{array}{l}\text { Acompanhamento de tratamento padronizado } \\
\text { de malária }\end{array}$ & Acompanhamento de $100 \%$ dos casos & & & \\
\hline $\begin{array}{l}\text { Registro de atendimentos de tuberculose e } \\
\text { malária }\end{array}$ & Registro de $100 \%$ dos casos atendidos & & & \\
\hline Número de AIS aptos para o Módulo 2 & $100 \%$ dos AIS capacitados no Módulo 1 & & & \\
\hline
\end{tabular}


FORMAÇĀO DE AGENTES INDIGENAS DE SAÚdE - AVALIAÇĀO DE PRODUTOS

\begin{tabular}{|l|l|l|}
\hline DSEI: & Número de AlS existentes: e capacitados:: & Número de comunidades: \\
\hline
\end{tabular}

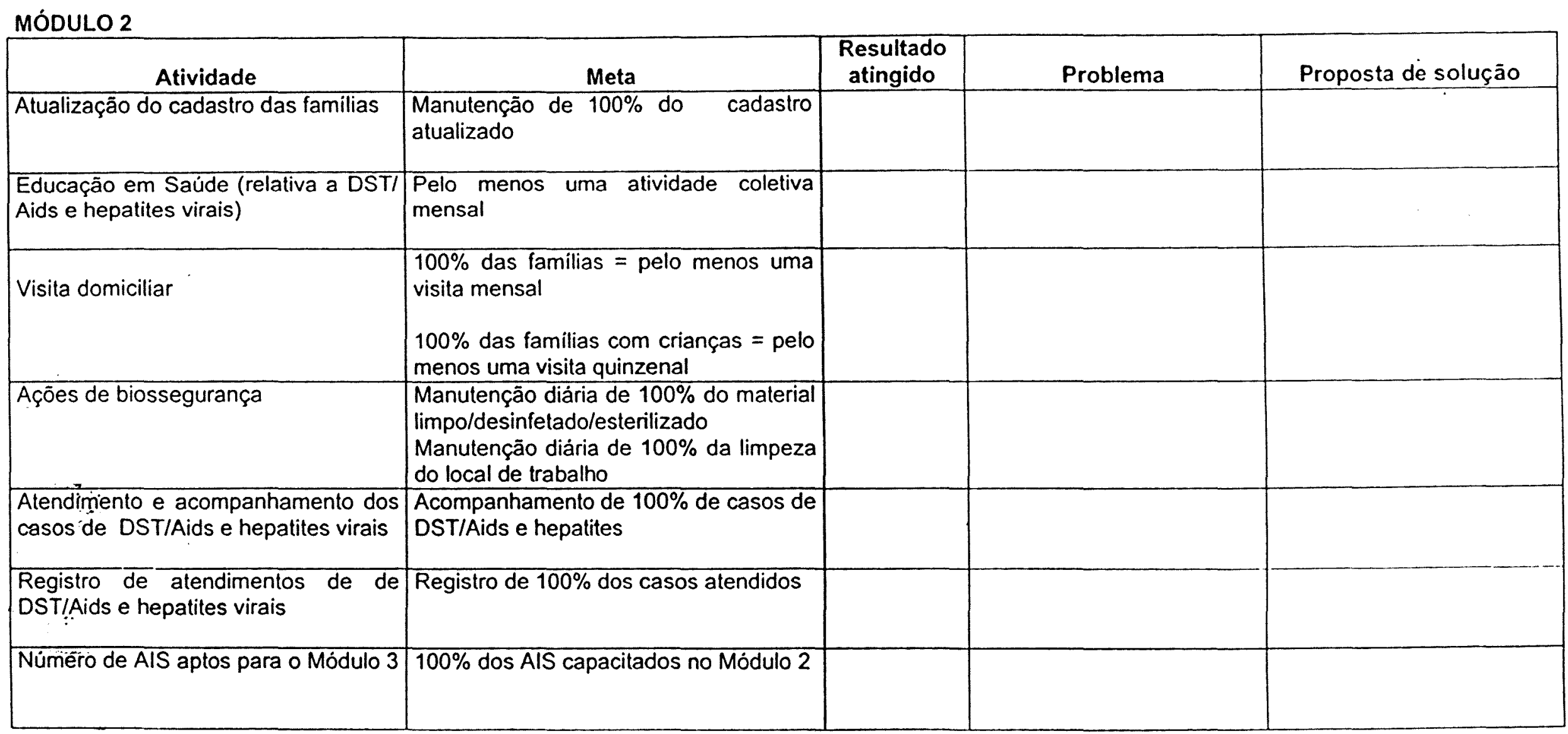




\section{ORIENTAÇÕES:}

Esse instrumento tem por finalidade subsidiar o DESAI na avaliação de produtos do processo de formação de Agentes Indigenas de Saúde. a partir do desenvolvimento de cada módulo do curso.

O preenchimento deverá ser feito, preferencialmente, por um enfermeiro da equipe DSEI que esteja acompanhando o processo de formação, observando-se os seguintes aspectos:

As atividades descritas referem-se ao consolidado dos desempenhos dos AIS no periodo de dispersão:

O campo relativo às Metas corresponde ao resultado esperado em relação às atividades propostas para o Módulo;

s. Para realização dos registros de atendimento, orienta-se a utilização de outras estratégias com os Als que não dominam a escrita (códigos, simbolos, desenhos, registro na própria lingua, fichas coloridas etc.)

Considera-se como fonte de dados os livros e outros instrumentos de registro de atendimentos realizados pelos AIS

O campo Resultados atingidos corresponde à quantificação de cada atividade, em relação às metas;

Os campos Problema e Proposta de solução referem-se, respectivamente, às dificuldades que inviabilizaram o cumprimento da mela proposta e as estratégias adotadas para seu enfrenlamento.

\section{- Utilizar esse espaço para observaçōes e sugestōes.}




\section{Anexo 17- Listagem de filmes consultados}

Vídeo Educativo: Saneamento e Higiene no Xingu. PI Pavuru, 1997. Produção: Universidade Federal de São Paulo/ Unidade de Saúde e Meio Ambiente, 1998. Duração: 7 minutos.

EPM-30 anos de Xingu-jornalístico e documentário Produção: TV Manchete, 1995. Duração: 60 minutos.

Lê bien-etre,Ducumentário filmado no Xingu e Paris. Produção: IO Paris, 1997. Duração: 53 minutos.

KAMENA-Desenho animado. Produção: Universidade Federal de São Paulo/ Unidade de Saúde e Meio Ambiente e Unicamp, julho de 1995. Duração: 8 minutos.

Xingu, história e fotografias. Produção: Universidade Federal de São Paulo/ Unidade de Saúde e Meio Ambiente, 1993. Duração: 8 minutos.

30 anos de EPM no Xingu. Entrevistas e documentário. Produção: Universidade Federal de São Paulo/ Unidade de Saúde e Meio Ambiente, 1995. Duração: 22 minutos.

Jô Soares entrevista Orlando Villas Boas. Cópia autorizada pela rede Globo, 1995 Duração: 14 minutos.

Programa de Índio. Documentário e jornalístico. TV Universitária, 1997 Duração: 21 minutos.

TV que o índio vê. Programa de Índio, 1-2-3-4 .TV Universitária, Brasília, 1998 Duração: 4 programas de 10 minutos.

Clip dos índios Xavante com a banda Sepultura. Produção Warner/CTI, 1998.

Associação Bakairi. Cenas cotidianas e o trabalho dos agentes de saúde. Bakairi, 1992. Duração 6 minutos.

Bororo. Cinemateca Brasileira e TV Universidade. S/d. Duração: 20 minutos.

Índios de Pimentel Barbosa. Warner e Quilombo, 1998. Duração: 13 minutos.

Magic World to U 'Ukre indians: Kaxinawa medicine man. USA/Bolívia, 1993. Duração: 14 minutos. 
Rio Sagrado da língua Pano. Interlab, São Paulo, 1994. Duração: 14 minutos.

Bearing life burdens. Documentário sobre carregadores de Quechua. USA/Bolívia, 1994. Duração: 55 minutos.

Raoni. Condições de via e história dos povos Yawalapiti, Kajabi, Suiá e Krenakore. Produção: USA/Brasil, 1976. Duração: 84 minutos.

A árvore dos tamancos. Itália, 1978. Ermano Olmi, 120 minutos.

Saúde, sentir de todos. Vídeo Fundacion Etnollano. Programa COAMA, Colômbia, 1995.

Krahö, os filhos da terra. CAI/Ibase, 1992. Duração: 36 minutos.

Eu já fui seu irmão. Duração sobre os índios Paraketejê. CTI, 1993/94. Duração, 16 minutos.

O espírito da TV. Documentário sobre os Nhambiquara e seus costumes. FAPESP/CT, 1990. Duração: 11 minutos.

O Brasil e os índios gigantes. ISA/EDF/RFI. 1995. História de contato com os índios Panará. Duração: 47 minutos.

Projeto Xingu. Curso de Formação de Auxiliares de Enfermagem Indígenas. PI Pavuru, 1997. Universidade Federal de São Paulo. TV Unifesp. Duração: 18 minutos.

O corpo e os espíritos. Práticas de medicina ocidental e tradicional no Xingu. Universidade Federal de São Paulo e Mari Correa, 1995. Durarção: 32 minutos.

O povo brasileiro. Darci Ribeiro. TV Cultura, 1995. Duração: 80 minutos.

Segredos da Mata Apina. CTI, 1993.

Avá Canoeiro, o desfecho final. CTI, 1994. Duração: 26 minutos.

AIDS-0 caso Tirió e Wiapi. Coordenação Nacional DST/AIDS. Brasília, 1999. Duração: 23 minutos.

Universidade Federal de São Paulo. Projeto Xingu. Formatura dos Auxiliares de Enfermagem Indígenas. São Paulo, 2001. Dưração: 18 minutos. 